\title{
Pensions at a Glance
}

PUBLIC POLICIES ACROSS OECD COUNTRIES

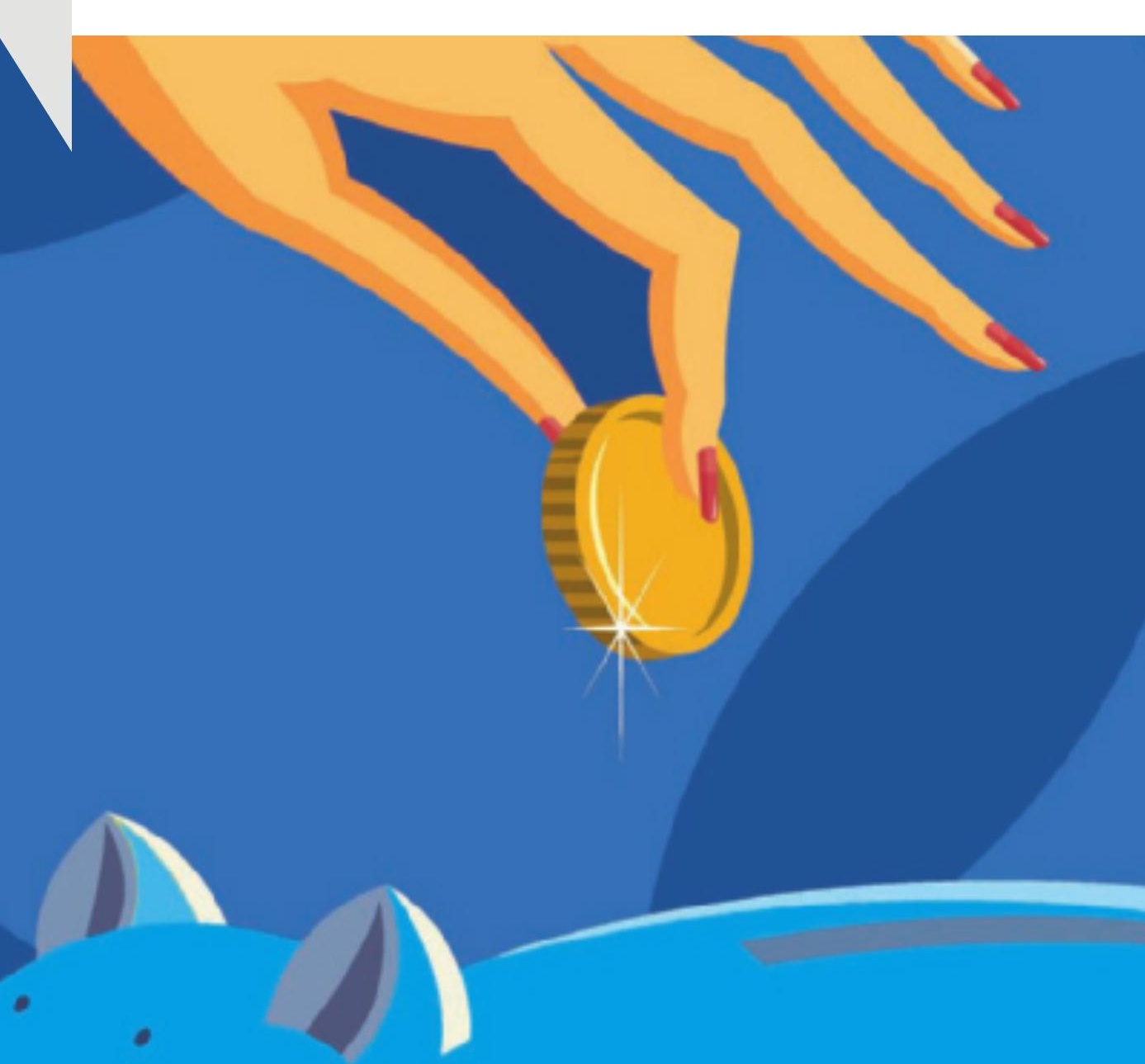





\title{
Pensions at a Glance
}

\section{PUBLIC POLICIES ACROSS OECD COUNTRIES}

\author{
2007 Edition
}




\section{ORGANISATION FOR ECONOMIC CO-OPERATION AND DEVELOPMENT}

The OECD is a unique forum where the governments of 30 democracies work together to address the economic, social and environmental challenges of globalisation. The OECD is also at the forefront of efforts to understand and to help governments respond to new developments and concerns, such as corporate governance, the information economy and the challenges of an ageing population. The Organisation provides a setting where governments can compare policy experiences, seek answers to common problems, identify good practice and work to co-ordinate domestic and international policies.

The OECD member countries are: Australia, Austria, Belgium, Canada, the Czech Republic, Denmark, Finland, France, Germany, Greece, Hungary, Iceland, Ireland, Italy, Japan, Korea, Luxembourg, Mexico, the Netherlands, New Zealand, Norway, Poland, Portugal, the Slovak Republic, Spain, Sweden, Switzerland, Turkey, the United Kingdom and the United States. The Commission of the European Communities takes part in the work of the OECD.

OECD Publishing disseminates widely the results of the Organisation's statistics gathering and research on economic, social and environmental issues, as well as the conventions, guidelines and standards agreed by its members.

This work is published on the responsibility of the Secretary-General of the OECD. The opinions expressed and arguments employed herein do not necessarily reflect the official views of the Organisation or of the governments of its member countries.

Also available in French under the title:

Panorama des politiques publiques

LES PENSIONS DANS LES PAYS DE L'OCDE

No reproduction, copy, transmission or translation of this publication may be made without written permission. Applications should be sent to OECD Publishing: rights@oecd.org or by fax (33-1) 452499 30. Permission to photocopy a portion of this work should be addressed to the Centre français d'exploitation du droit de copie (CFC), 20, rue des Grands-Augustins, 75006 Paris, France, fax (33-1) 463467 19, contact@cfcopies.com or (for US only) to Copyright Clearance Center (CCC), 222 Rosewood Drive Danvers, MA 01923, USA, fax (978) 646 8600, info@copyright.com. 


\section{Foreword}

$\Gamma$

his report provides indicators for comparing pension policies across OECD countries. It gives estimates of the level of pension people will receive if they work for a full career and if today's pension rules stay unchanged.

Monika Queisser and Edward Whitehouse of the Social Policy Division of the OECD's Directorate for Employment, Labour and Social Affairs prepared the report. Rie Fujisawa and Edward Whitehouse were responsible for the pension modelling and the analysis of the tax position of pensioners. Anna Cristina D'Addio and Jongkyun Choi assisted in finalising the report.

National officials provided invaluable, active assistance in collecting information on their countries' pension and tax systems. The results have been confirmed by national authorities with the exception of those for Italy, which are based on the OECD's interpretation of parameters and rules provided by the government.*

Numerous OECD colleagues provided guidance and information, particularly Mark Pearson, Martine Durand and John Martin. The OECD private-pensions team in the Directorate of Financial and Enterprise Affairs - particularly Fiona Stewart and Juan Yermo - provided useful input to the special feature on private pensions. Delegates to the OECD Working Party on Social Policy advised on modelling procedures and development of indicators for cross-country comparisons of pension systems. They also gave constructive comments on earlier drafts.

The report is the product of a joint project co-financed by the European Commission and the OECD; the project also benefited from a financial contribution made by the government of Switzerland.

The OECD pension models use the APEX (Analysis of Pension Entitlements across Countries) infrastructure originally developed by Axia Economics, with the help of funding from the OECD and the World Bank.

\footnotetext{
* Italy has expressed serious doubts about the adequacy of data used in the report, and consequently about the comparability of results. In particular, baseline assumptions about labour market entry ages and career length (respectively, 20 and 45 years) are different from those agreed in a comparable exercise undertaken at the EU level, and differ from current Italian labour market norms. Italy thinks interpretations based on these data may be misleading.
} 


\section{Table of Contents}

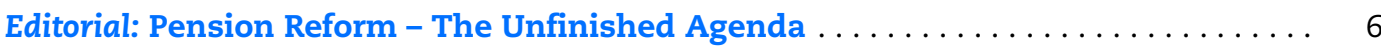

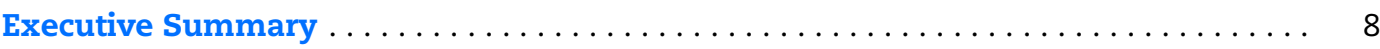

Structure of the Report and Methodology $\ldots \ldots \ldots \ldots \ldots \ldots \ldots \ldots \ldots \ldots \ldots \ldots \ldots$

Part I

Comparing Pension Policies of OECD Countries

Overview of Retirement-Income Provision $\ldots \ldots \ldots \ldots \ldots \ldots \ldots \ldots \ldots \ldots \ldots \ldots \ldots$

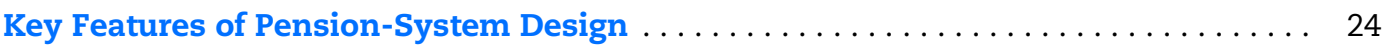

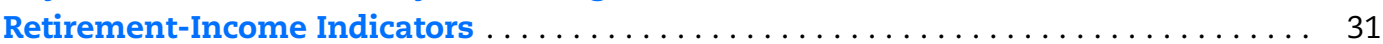

Gross Pension Replacement Rates. . . . . . . . . . . . . . . . . . . 32

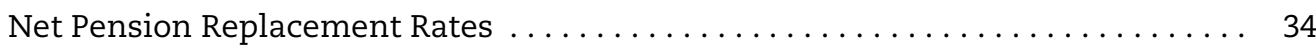

Gross Pension Replacement Rates with Entry at Age $25 \ldots \ldots \ldots \ldots \ldots \ldots$

Gross Pension Replacement Rates with Different Investment Returns . . . . . . . 38

Gross Pension Wealth . . . . . . . . . . . . . . . . . . . . . . . . . 40

Net Pension Wealth................................. 42

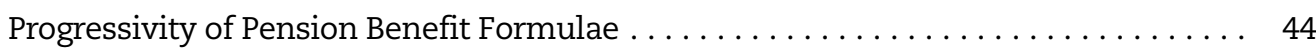

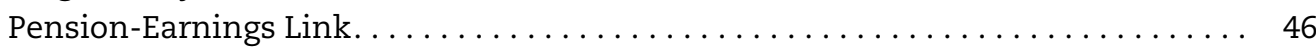

Weighted Averages: Pension Levels and Pension Wealth $\ldots \ldots \ldots \ldots \ldots \ldots \ldots .48$

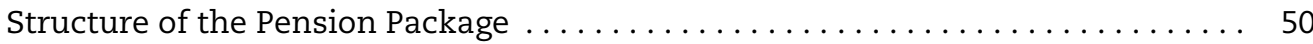

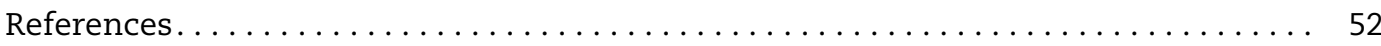

Part II

\section{Pension Reforms and Private Pensions}

1. A Decade of Pension Reforms: The Impact on Future Benefits . . . . . . . . . . 55

1.1. Overview of pension reforms in OECD countries . . . . . . . . . . 55

1.2. Impact of pension reforms in selected OECD countries ............. 64

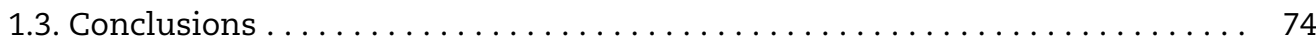

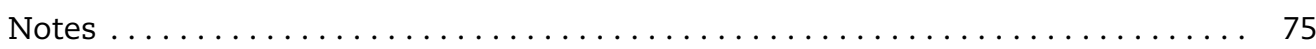

2. The Role of Private Pensions in Providing Future Retirement Incomes . . . . . . 76

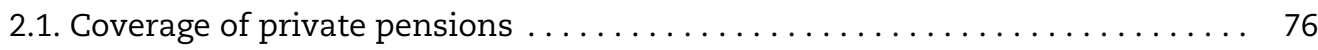

2.2. Types of voluntary private pension provision $\ldots \ldots \ldots \ldots \ldots \ldots \ldots \ldots \ldots$

2.3. Mandatory replacement rates and the pension savings gap . . . . . . . 80

2.4. Mandatory replacement rates and private-pension coverage $\ldots \ldots \ldots \ldots . . \ldots 1$

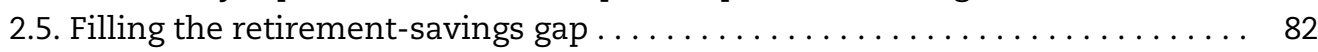

2.6. Contribution density and the retirement-savings gap $\ldots \ldots \ldots \ldots \ldots \ldots \quad 85$

2.7. Real rates of return on investments and the retirement-savings gap . . . . . 86

2.8. Indicative gross replacement rates including voluntary pensions . . . . . . 86

2.9. Conclusions and future developments $\ldots \ldots \ldots \ldots \ldots \ldots \ldots \ldots \ldots$ 
Notes ....................................... 89

Annex. Gross Replacement Rates Including Defined-Benefit Occupational Plans . . . . 90

References...................................... 92

Part III

Country Studies

Introduction $\ldots \ldots \ldots \ldots \ldots \ldots \ldots \ldots \ldots \ldots \ldots \ldots \ldots \ldots \ldots \ldots \ldots$

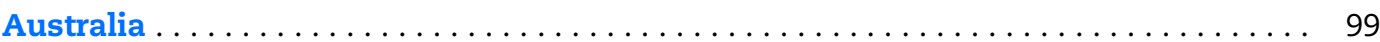

Austria . . . . . . . . . . . . . . . . . . . . . . . . . . . . . . . 102

Belgium . . . . . . . . . . . . . . . . . . . . . . . . . . . . . . . . . 105

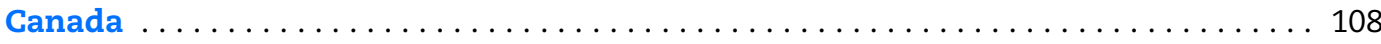

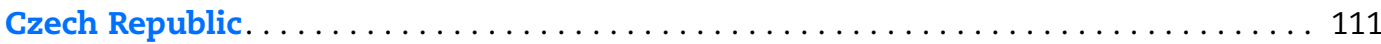

Denmark . . . . . . . . . . . . . . . . . . . . . . . . . . . . . . . . . . . . . . . 114

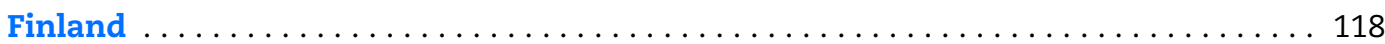

France . . . . . . . . . . . . . . . . . . . . . . . . . . . . . . . 122

Germany . . . . . . . . . . . . . . . . . . . . . . . . . . . . . . . 127

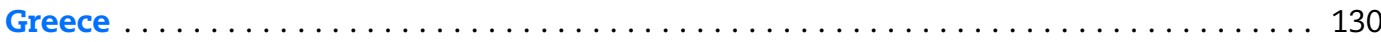

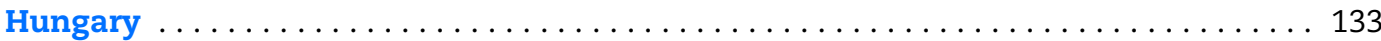

Iceland . . . . . . . . . . . . . . . . . . . . . . . . . . . . . . . . . . . . . . . . . . 137

Ireland . . . . . . . . . . . . . . . . . . . . . . . . . . . . . . . . . 140

Italy . . . . . . . . . . . . . . . . . . . . . . . . . . . . . . . . . . . . . . . . . 142

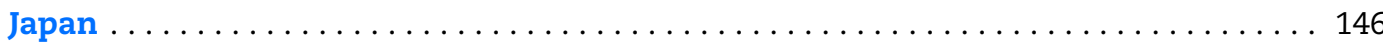

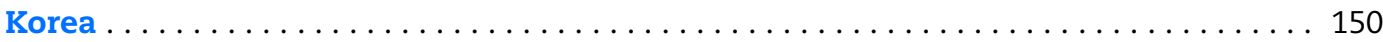

Luxembourg . . . . . . . . . . . . . . . . . . . . . . . . . . 153

Mexico........................................ 156

Netherlands . . . . . . . . . . . . . . . . . . . . . . . . . . . . . . . . . . . . . . . 159

New Zealand . . . . . . . . . . . . . . . . . . . . . . . . . . . . . . . . 162

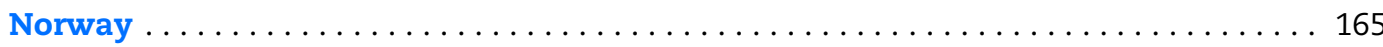

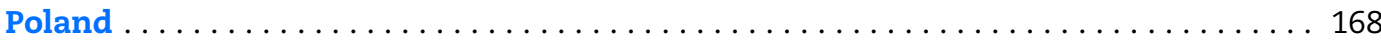

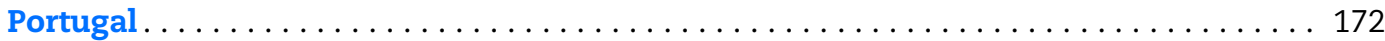

Slovak Republic . . . . . . . . . . . . . . . . . . . . . . . . . . . . . . . . . . . . . 177

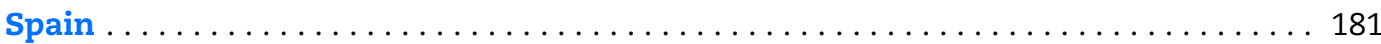

Sweden . . . . . . . . . . . . . . . . . . . . . . . . . . . . . . . . . . . . . . . . . . . 184

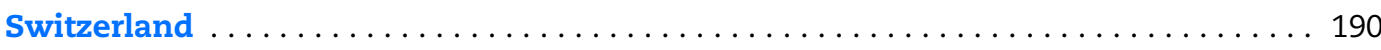

Turkey . . . . . . . . . . . . . . . . . . . . . . . . . . . . . . . . . . . . . . . . . . . 194

United Kingdom . . . . . . . . . . . . . . . . . . . . . . . . . . 198

United States . . . . . . . . . . . . . . . . . . . . . . . . . . . . . . . . . . . . . . 202

\section{This book has...}

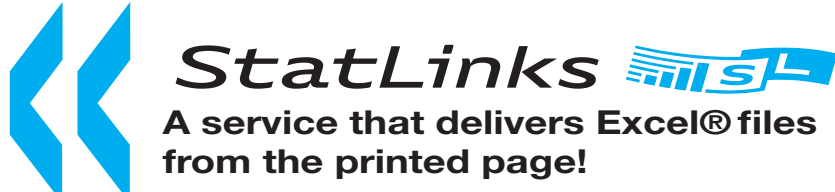

Look for the StatLinks at the bottom right-hand corner of the tables or graphs in this book. To download the matching Excel $\circledast$ spreadsheet, just type the link into your Internet browser, starting with the http://dx.doi.org prefix.

If you're reading the PDF e-book edition, and your PC is connected to the Internet, simply click on the link. You'll find StatLinks appearing in more OECD books. 


\section{Editorial \\ Pension Reform: The Unfinished Agenda}

$S_{\text {i }}$

ince the early 1990s, pension reform has been high on the agenda in many OECD countries. Governments have either undertaken far-reaching, structural pension reforms or adopted a series of smaller reforms which, taken together, affect future pension entitlements substantially. These reforms, like pension systems themselves, have had many diverse and complex features. They have included, among other things, increases in pension ages, changes in the way that benefits are calculated and smaller real pension increases than in the past. However, despite the different approaches, there is a clear underlying trend towards a reduced pension promise for today's workers, when compared with past generations. This is necessary to ensure the financial sustainability of pension systems for both current and future retirees.

To the extent that this objective is achieved, this is good news. But there is no reason for complacency. Even though pension reforms were substantial in the OECD as a whole, the agenda remains unfinished. This unfinished agenda includes five main issues.

First, some countries still need a fundamental overhaul of their public pension schemes. In Greece and Spain, for example, full-career workers can expect sizeable pension benefits if they retire at the standard pension age. But in reality many retirees receive only the minimum pension because of insufficient contribution coverage. At the same time, these countries also have incentives that encourage early retirement. Population ageing will increase the financial pressure on these schemes and reforms are needed urgently.

Second, some major pension reforms are being phased in too slowly. This is the case in Austria, Italy, Mexico and Turkey. In Turkey, for example, the new retirement age of 65 will only be reached in 2043 for men and even later for women. In Austria and Mexico, people who were already covered by the public pension scheme (even for a short period) are guaranteed that their benefit is either no lower or only a little lower than under the old system. Finally, the reform of 1995 in Italy will only begin to affect people who retire around 2017 or later. Even though the long-run financial position of the pension systems of these countries is much improved, the slow pace of change will result in many decades more of relatively high expenditures. These financial pressures might require ad-hoc, short-term adjustments that may perversely cause more hardship than faster reforms would have done.

Third, while a common response to a reduced pension promise is to exhort workers to save more for their own retirement, saving through voluntary plans might not be sufficient to ensure adequate replacement of pre-retirement incomes. This has long been an issue in countries such as Ireland, New Zealand, the United Kingdom and the United States where the public pensions are relatively small, especially for middle and high earners. In the future, more countries will face the same problem: reductions in public pensions will 
require more personal savings to maintain retirement living standards. One way of boosting coverage of voluntary private pensions is through so-called "automatic enrolment", under which workers are covered unless they opt out. This was recently introduced in New Zealand and is under discussion elsewhere. Another route to broaden private pension coverage is to extend collective bargaining to embrace retirement-income issues. For example, the Netherlands and the Nordic countries ensure almost-universal coverage of supplementary pensions in this way.

Fourth, many pension systems still encourage early retirement even though the standard retirement age has been raised to 65 years in most OECD countries and, in some cases, even beyond. Several countries have tried to close pathways into early retirement through unemployment or disability benefits, for example. Some countries will in future link retirement ages or benefit levels to changes in life expectancy. These steps are promising, but will have to stand the test of time. Recent experience has shown that some countries have failed to apply the rules that adjust pensions to life-expectancy increases due to political pressures or electoral cycles.

Fifth, some of the reforms might result in a greater risk of poverty in old-age for lowincome workers. A number of countries - such as Italy, Poland and the Slovak Republic - have introduced much closer links between contributions paid into the pension systems and later retirement benefits. While this should encourage workers to work longer, it also increases the risk of being poor in retirement for those who have low incomes throughout their working life or those who have missing periods of contributions due to unemployment, caring periods or moves between dependent employment and self-employment. Countries will have to monitor closely the income situation of retirees and establish safety-nets to prevent a resurgence of old-age poverty.

Pension reform can be politically difficult. But the experience of the OECD countries over the past 10-15 years suggests that obstacles to pension reform are not insuperable: more than half of them have had major changes over that period. The pension-reform laggards should take heart from this experience and press ahead with necessary changes to their retirement-income systems.

John P. Martin

Director, Employment, Labour and Social Affairs, OECD 


\section{Executive Summary}

$\mathrm{T}$ his second edition of Pensions at a Glance updates all the important indicators of retirement-income systems developed for the first edition. The values of all pension system parameters reflect the situation in the year 2004. The general approach adopted is a "microeconomic" one, looking at prospective individual entitlements under all 30 of OECD member countries' pension regimes.

The report starts by showing the different schemes that together make up national retirement-income provision, including a summary of the parameters and rules of pension systems. This is followed by eight main indicators of pension income that are calculated using the OECD pension models. This issue also contains two special analyses on pension reforms and private pensions, which use the OECD pension models to explore more deeply the central issues of pension policy in national debates. Finally, the report provides detailed background information on each of the 30 countries' retirement-income arrangements.

For workers at average earnings, the average for the OECD countries of the gross replacement rate, i.e. the ratio between pension benefit and pre-retirement earnings, from mandatory pensions is $59 \%$. But taxes play an important role in old-age support. Pensioners often do not pay social security contributions and, as personal income taxes are progressive and pension entitlements are usually lower than earnings before retirement, they usually pay less taxes. For average earners, the net replacement rate across OECD countries is $70 \%$ on average, some 11 percentage points higher than the average gross replacement rate.

For low earners, the average net replacement rate across OECD countries is $83 \%$. But there are regional differences: the Nordic countries offer a 95\% net replacement rate to workers on half average earnings while the Anglophone OECD countries pay $76 \%$ of previous net earnings.

What matters for governments, however, is not only the replacement rate but the value of the overall pension promise. This is measured by the indicator of pension wealth which takes life expectancy and the indexation of pensions in payment into account. Using this indicator, the pension promise is most expensive in Luxembourg. On average, each male pensioner will receive the equivalent of USD 920000 and each female retiree over USD 1 million. The Netherlands and Greece rank second and third on this measure. The most modest pension systems are those of Belgium, Ireland, Japan, the United Kingdom and the United States where pension wealth is around two-thirds of the average for OECD countries. The lowest ranking is occupied by Mexico where men and women are promised a pension equivalent to USD 34000 and 32 000, respectively.

Nearly all the 30 OECD countries have made at least some changes to their pension systems since 1990. As a result, the average pension promise in the 16 countries - whose 
reforms are studied in this report - was cut by $22 \%$. For women, the reduction was $25 \%$. Only in two of the 16 countries - Hungary and the United Kingdom - were there increased pension promises on average.

How will these changes affect different individuals? Some countries - such as France, Portugal and the United Kingdom - are moving towards greater targeting of public pensions on low earners thus bolstering the safety-net. Others - such as Poland and the Slovak Republic - have moved to tighten the link between pension entitlements and earnings, which may put low-earners at a higher risk of poverty. In Germany, Japan, Mexico, Poland and the Slovak Republic, for example, the net pension entitlement for a full-career worker with half average earnings was around $41 \%$ of average earnings before reform, slightly below the average for the OECD as a whole. The reforms will cut this to just $32.5 \%$. In contrast, Finland, France, Hungary, Korea, New Zealand and the United Kingdom have protected low-income workers from cuts in benefits in their pension reforms.

The intense reform activity in OECD countries means that today's workers will have to do more on their own to prepare for tomorrow's retirement. In some countries, the savings effort necessary to reach the OECD average replacement rate is substantial, even if workers save throughout their entire career. If young workers miss out on the first 10 or 15 years of their career because of other demands on their budget, reaching a sufficient pension level will become even more difficult. This report illustrates how important it is that workers start saving early and contribute regularly. 



\section{Structure of the Report and Methodology}

$\mathrm{T}$ he general approach of Pensions at a Glance is a "microeconomic" one, looking at prospective individual entitlements under all 30 of OECD member countries' pension regimes. This method is designed to complement alternative comparisons of retirementincome systems: long-term fiscal and financial projections (for example, Dang et al., 2001; and European Union, 2006) and analysis of income-distribution data (such as Förster and Mira d'Ercole, 2005; and Disney and Whitehouse, 2001).

The report is divided into three main parts. Part I presents the information needed to compare pension policies in a clear, "at a glance" style. It starts by showing the different schemes that together make up national retirement-income provision. Next, there is a summary of the parameters and rules of pension systems.

This is followed by eight main indicators that are calculated using the OECD pension models.

- The first two are the most familiar to pension analysts. Both are replacement rates, i.e., the ratio of pension benefits to individual earnings. These are given in gross and net terms, taking account of taxes and contributions paid on earnings and on retirement incomes. Two analyses of the sensitivity of the gross replacement rate follow. The first looks at individuals who enter the pension system later than the baseline assumption, while the second considers the importance of investment returns in pension systems with defined-contribution (DC) components.

- The next two indicators are pension wealth, again given in gross and net terms. Pension wealth is a more comprehensive measure of pension entitlements than replacement rates because it takes account of pension ages, indexation of pensions to changes in wages or prices and life expectancy.

- Countries differ in the way that their pension systems aim to provide an old-age safetynet or replace a target share of pre-retirement income. The balance between these two is explored by the next pair of indicators: the first on the progressivity of the pension benefit formula and the second on the link between pension and earnings.

- The final two indicators aim to summarise the pension system as it affects individuals across the earnings distribution, showing the average pension level, pension wealth and the contribution of each component of the retirement-income system to overall benefits.

Two special chapters form Part II of this report. They cover pension reforms and private pensions, respectively. Both of these analyses use the OECD pension models to explore more deeply the central issues of pension policy in national debates. The framework of Pensions at a Glance is forward-looking, focusing on future pension entitlements of today's 
workers. However, the past decade has seen intense reform activity in the world of pensions and retirement. The first special chapter looks at what countries did and how this is likely to affect future benefits. A number of these reforms have increased the role of the private sector in pension provision. The second special chapter identifies the complex range of private retirement arrangements and quantifies the savings effort individuals will have to make to maintain standards of living in retirement.

Finally, Part III provides detailed background information on each of the 30 countries' retirement-income arrangements. These include pension eligibility ages and other qualifying conditions; the rules for calculating benefit entitlements; the treatment of early and late retirees; and more detailed information on the pre-reform scenarios explored in the special chapter on pension reforms. The country studies summarise the national results in standard charts and tables.

The remainder of this section describes the methodology used to calculate pension entitlements. It outlines the details of the structure, coverage and basic economic and financial assumptions underlying the calculation of future pension entitlements on a comparative basis.

\section{Future entitlements under today's parameters and rules}

The pension entitlements which are compared are those that are currently legislated in OECD countries. Changes in rules that have already been legislated, but are being phased-in gradually, are assumed to be fully in place from the start. Reforms that have been legislated since 2004 are included where sufficient information is available (in Portugal, for example). Some changes (such as the increase in pension age in Germany and the reform package in the United Kingdom) have not been finalised or were finalised too late for inclusion.

The values of all pension system parameters reflect the situation in the year 2004. The calculations show the pension entitlements of a worker who enters the system today and retires after a full career. The results are shown for a single person only.

\section{Career length}

A full career is defined here as entering the labour market at age 20 and working until the standard pension-eligibility age, which, of course, varies between countries. The implication is that the length of career varies with the statutory retirement age: 40 years for retirement at 60, 45 years for retirement at 65 , etc. As the results can be sensitive to the career-length assumption, calculations are also made for situations where workers enter at age 25 and so retire with five years less than a full career.

\section{Coverage}

The pension models presented here include all mandatory pension schemes for private-sector workers, regardless of whether they are public (i.e. they involve payments from government or from social security institutions, as defined in the System of National Accounts) or private. For each country, the main national scheme for private-sector employees is modelled. Schemes for civil servants, public-sector workers and special professional groups are excluded. 
Systems with near-universal coverage are also included provided they cover at least $90 \%$ of employees. This applies to schemes such as the occupational plans in Denmark, the Netherlands and in Sweden. An increasing number of OECD countries have broad coverage of voluntary, occupational pensions and these play an important role in providing retirement incomes. For these countries, a second set of results is shown with voluntary pension schemes in the special chapter on private pensions.

Resource-tested benefits for which retired people may be eligible are also modelled. These can be means-tested, where both assets and income are taken into account, purely income-tested or withdrawn only against pension income. The calculations assume that all entitled pensioners take up these benefits. Where there are broader means tests, taking account also of assets, the income test is taken as binding. It is assumed that the whole of income during retirement comes from the mandatory pension scheme (or from voluntary pension schemes in those countries where they are modelled).

Pension entitlements are compared for workers with earnings between 0.5 times and twice the economy-wide average. This range permits an analysis of future retirement benefits of both the poorest and richer workers.

\section{Economic variables}

The comparisons are based on a single set of economic assumptions for all 30 countries. In practice, the level of pensions will be affected by economic growth, wage growth and inflation, and these will vary across countries. A single set of assumptions, however, ensures that the comparisons of the different pension regimes are not affected by different economic conditions. In this way, differences across countries in pension levels reflect differences in pension systems and policies alone.

The baseline assumptions are:

- real earnings growth: $2 \%$ per year (given the assumption for price inflation, this implies nominal wage growth of $4.55 \%$ );

- individual earnings: assumed to grow in line with the economy-wide average. This means that the individual is assumed to remain at the same point in the earnings distribution, earning the same percentage of average earnings in every year of the working life;

- price inflation: $2.5 \%$ per year;

- real rate of return after administrative charges on funded, defined-contribution pensions: $3.5 \%$ per year;

- discount rate (for actuarial calculations): $2 \%$ per year (see Queisser and Whitehouse, 2006 for a discussion of the discount rate);

- mortality rates: the baseline modelling uses country-specific projections (made in 2002) from the United Nations/World Bank population database for the year 2040;

- earnings distribution: composite indicators use the OECD average earnings distribution (based on 18 countries), with country-specific data used where available.

Changes in these baseline assumptions will obviously affect the resulting pension entitlements. The indicators are therefore also shown for alternative assumptions regarding the rate of return on funded defined-contribution schemes. The impact of variations in economy-wide earnings growth, and for individual earnings growing faster or slower than the average, was shown in the first edition of Pensions at a Glance (OECD, 2005) 
The real rate of return on defined-contribution pensions is assumed to be net of administrative charges. In practice, this assumption might disguise genuine differences in administrative fees between countries (see Whitehouse, 2000 and 2001 for an analysis).

The calculations assume the following for the pay-out of pension benefits: when DC benefits are received upon retirement, they are paid in the form of a price-indexed life annuity at an actuarially fair price. This is calculated from mortality data. Similarly, the notional annuity rate in notional accounts schemes is (in most cases) calculated from mortality data using the indexation rules and discounting assumptions employed by the respective country.

\section{Taxes and social security contributions}

Information on taxes and social security contributions which were used to calculate the net indicators for 2002 were included in the country chapters in the first edition of Pensions at a Glance (OECD, 2005). The tax and social security contribution rules and parameters have been updated to 2004 but are not repeated in this volume for reasons of space (Fujisawa and Whitehouse, forthcoming 2007, provides more information).

The modelling assumes that tax systems and social-security contributions remain unchanged in the future. This implicitly means that "value" parameters, such as tax allowances or contribution ceilings, are adjusted annually in line with average earnings, while "rate" parameters, such as the personal income tax schedule and social security contribution rates, remain unchanged. General provisions and the tax treatment of workers for 2004 can be found in the OECD report Taxing Wages (OECD, 2006). The conventions used in that report, such as which payments are considered taxes, are followed here.

\section{Average earnings}

Starting with this edition, Pensions at a Glance uses a new and more comprehensive measure of average earnings corresponding to an "average worker" (AW). This is broader than the previous benchmark of the "average manual production worker" (APW). This new concept was introduced in the report Taxing Wages (OECD, 2006) and also serves as benchmark for Benefits and Wages (OECD, 2007).

The reasoning behind the change was that a manual worker in the production sector is not representative of the "typical taxpayer", given the steady decline in manual employment in manufacturing in most OECD countries. The new base for calculating average earnings includes more economic sectors and both manual and non-manual workers. The concept and definition of earnings, however, remains the same: gross wage earnings paid to average workers, measured before deductions of any kind, but including overtime pay and other cash supplements paid to employees.

Table 0.1 reports average earnings levels under the old (APW) and new (AW) definition, for the year 2004. Only three countries (Ireland, Korea and Turkey) are not yet able supply earnings data on the broader basis and so the modelling is based on the old, APW measure of average earnings.

The effect of broadening the types of workers covered has very different effects on measured average earnings in different OECD countries. In 19 of the 27 countries for which new, AW data are available, these are higher than average earnings under the previous, APW definition but the size of the difference varies greatly (see Figure 0.1). The change in definition increases measured average earnings by $30 \%$ or more in six countries (Austria, 
Table 0.1. OECD measures of average earnings, 2004

National currency and USD at market price and purchasing-power-parity exchange rates

\begin{tabular}{|c|c|c|c|c|c|c|}
\hline & \multicolumn{4}{|c|}{$\mathrm{OECD}$ measure of average earnings } & \multicolumn{2}{|c|}{ Exchange rates with USD } \\
\hline & $\begin{array}{c}\text { Old - } \\
\text { National currency } \\
\text { (APW) }\end{array}$ & $\begin{array}{c}\text { New - } \\
\text { National currency } \\
\text { (AW) }\end{array}$ & $\begin{array}{c}\text { New - } \\
\text { USD, market price }\end{array}$ & $\begin{array}{c}\text { New- } \\
\text { USD, PPP }\end{array}$ & Market price & PPPs \\
\hline Australia & 52777 & 48827 & 35922 & 35917 & 1.36 & 1.36 \\
\hline Austria & 24946 & 32872 & 40842 & 37872 & 0.80 & 0.868 \\
\hline Belgium & 32281 & 35578 & 44205 & 41151 & 0.80 & 0.865 \\
\hline Canada & 40912 & 38945 & 29933 & 31269 & 1.30 & 1.25 \\
\hline Czech Republic & 213573 & 209489 & 8153 & 14936 & 25.69 & 14.03 \\
\hline Denmark & 323900 & 316500 & 52860 & 37684 & 5.99 & 8.40 \\
\hline Finland & 29152 & 31539 & 39186 & 32372 & 0.80 & 0.974 \\
\hline France & 23087 & 29549 & 36713 & 32199 & 0.80 & 0.918 \\
\hline Germany & 34088 & 41046 & 50998 & 45898 & 0.80 & 0.894 \\
\hline Greece & 12525 & 17360 & 21569 & 24996 & 0.80 & 0.695 \\
\hline Hungary & 1262712 & 1697268 & 8377 & 13682 & 202.61 & 124.05 \\
\hline Iceland & 2849554 & 2770000 & 39463 & 29461 & 70.19 & 94.02 \\
\hline Ireland & 30170 & n.a. & 37485 & 30321 & 0.80 & 1.00 \\
\hline Italy & 23044 & 22053 & 27400 & 25628 & 0.80 & 0.861 \\
\hline Japan & 4223100 & 4943208 & 45708 & 37139 & 108.15 & 133 \\
\hline Korea & 27356688 & n.a. & 23888 & 34974 & 1145.20 & 782 \\
\hline Luxembourg & 32586 & 39171 & 48668 & 42649 & 0.80 & 0.918 \\
\hline Mexico & 66432 & 76332 & 6767 & 10446 & 11.28 & 7.31 \\
\hline Netherlands & 32457 & 37026 & 46003 & 41300 & 0.80 & 0.897 \\
\hline New Zealand & 41778 & 39428 & 26129 & 26793 & 1.51 & 1.47 \\
\hline Norway & 314523 & 366161 & 54332 & 41005 & 6.74 & 8.93 \\
\hline Poland & 26745 & 29263 & 8015 & 15858 & 3.65 & 1.85 \\
\hline Portugal & 9372 & 12969 & 16113 & 18344 & 0.80 & 0.707 \\
\hline Slovak Republic & 190000 & 200722 & 6228 & 11679 & 32.23 & 17.19 \\
\hline Spain & 17913 & 19828 & 24635 & 26215 & 0.80 & 0.756 \\
\hline Sweden & 251282 & 300814 & 40949 & 32773 & 7.35 & 9.18 \\
\hline Switzerland & 64419 & 70649 & 56849 & 40900 & 1.24 & 1.73 \\
\hline Turkey & 13959 & n.a. & 9789 & 16788 & 1.43 & 0.831 \\
\hline United Kingdom & 20560 & 27150 & 49747 & 43881 & 0.55 & 0.619 \\
\hline United States & 34033 & 30355 & 30355 & 30355 & 1.00 & 1.00 \\
\hline
\end{tabular}

n.a.: Not available.

AW $=$ average wage.

$\mathrm{APW}=$ average production worker.

$\mathrm{PPP}=$ purchasing power parity.

Note: Monetary values for Turkey divided by 1000 000. Average earnings are not available on the AW measure for Ireland, Korea and Turkey.

Source: OECD (2006), p. 13; and OECD Main Economic Indicators.

France, Greece, Hungary, Portugal and the United Kingdom). For three additional countries the increase was $20 \%$ (Germany, Luxembourg and Sweden). In contrast, a sizeable decrease occurred only in the United States (13\%), with more modest declines (of around 5\% or less) in seven further countries.*

\footnotetext{
* Countries have endeavoured to supply data based on the new Average Wage concept. However, as when any new series is introduced, there are teething problems and different interpretations of guidelines need to be reconciled. It appears possible, for example, that the US data excludes some groups that are included in other countries' estimates of the average wage, which may partly explain the surprisingly low US average wage estimate. This issue is subject of ongoing work, and updates to the wage series will be posted on the OECD website as and when they become available.
} 


\section{Figure 0.1. Percentage difference of average earnings AW levels with regard to previous APW levels, 2004}

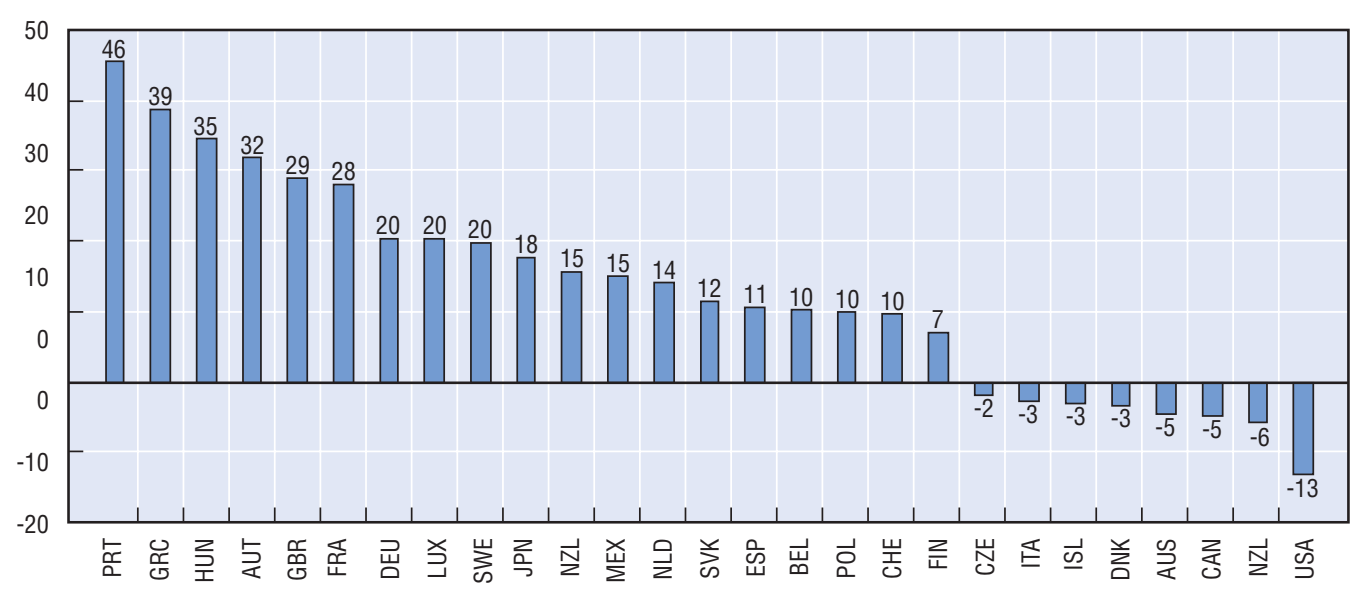

Source: OECD (2006), p. 13.

StatLink तinish $h t t p: / / d x . d o i . o r g / 10.1787 / 886456570455$

Table 0.2. Total life expectancy at age 65, 2040 projected mortality rates

\begin{tabular}{|c|c|c|}
\hline & Men & Women \\
\hline Australia & 84.0 & 87.4 \\
\hline Austria & 83.7 & 87.3 \\
\hline Belgium & 83.8 & 87.3 \\
\hline Canada & 83.8 & 87.4 \\
\hline Czech Republic & 82.5 & 86.0 \\
\hline Denmark & 83.1 & 86.0 \\
\hline Finland & 83.6 & 87.5 \\
\hline France & 83.9 & 87.6 \\
\hline Germany & 83.2 & 86.6 \\
\hline Greece & 83.3 & 86.6 \\
\hline Hungary & 80.8 & 85.0 \\
\hline Iceland & 84.8 & 87.5 \\
\hline Ireland & 82.8 & 86.2 \\
\hline Italy & 83.0 & 87.0 \\
\hline Japan & 85.8 & 88.7 \\
\hline Korea & 81.8 & 85.6 \\
\hline Luxembourg & 83.0 & 87.2 \\
\hline Mexico & 80.9 & 84.8 \\
\hline Netherlands & 83.5 & 86.7 \\
\hline New Zealand & 83.6 & 86.8 \\
\hline Norway & 84.2 & 87.5 \\
\hline Poland & 81.5 & 85.6 \\
\hline Portugal & 82.8 & 86.2 \\
\hline Slovak Republic & 81.1 & 85.1 \\
\hline Spain & 83.4 & 87.0 \\
\hline Sweden & 84.3 & 87.5 \\
\hline Switzerland & 84.5 & 88.2 \\
\hline Turkey & 80.0 & 83.0 \\
\hline United Kingdom & 83.3 & 86.4 \\
\hline United States & 83.8 & 87.3 \\
\hline OECD average & 83.1 & 86.6 \\
\hline
\end{tabular}

Note: These projections build on recent national census data. The assumptions for future changes in mortality rates vary between countries but nonetheless use a consistent methodology. The resulting mortality rates can differ from national projections because of differences in assumptions.

Source: OECD calculations based on United Nations/World Bank population database. 


\section{Demographics and life expectancy}

Table 0.2 shows the country-specific total life expectancy, separately for men and women, conditional on surviving until age 65. Given that pension entitlements are projected into the future, the calculations use the projections for 2040 from the United Nations/World Bank population database. Workers who enter the labour market in 2004 will retire between 2044 and 2051. Unfortunately, mortality-rate projections are available only for 2040 and 2075.

Citizens of poorer OECD member states are projected to retain lower life expectancies than their counterparts in richer economies. In Hungary, Mexico, Poland, the Slovak Republic and Turkey, life expectancy at age 65 is $1 \frac{1}{2} 2-3$ years shorter than the OECD average. Japan and Switzerland have significantly longer life expectancy than the OECD mean today and are projected to remain at the top in 2040. Other countries are clustered around the OECD average. 


\section{References}

Dang, T.T., P. Antolín and H. Oxley (2001), "Fiscal Implications of Ageing: Projections of Age-Related Spending”, Working Paper No. 305, Economics Department, OECD, Paris.

Disney, R.F. and E.R. Whitehouse (2001), “Cross-Country Comparisons of Pensioners' Incomes”, Report Series No. 142, Department for Work and Pensions, London.

European Union, Economic Policy Committee (2006), “The Impact of Ageing on Public Expenditure: Projections for the EU-25 Member States on Pensions, Health Care, Long-term Care, Education and Unemployment Transfers (2004-2050)", European Economy, Special Reports No. 1/2006.

Förster, M. and M. Mira d'Ercole (2005), "Income Distribution and Poverty in OECD Countries in the Second Half of the 1990s", Social, Employment and Migration Working Paper No. 22, OECD, Paris.

Fujisawa, R. and E.R. Whitehouse (forthcoming 2007), “The Role of the Tax System in Old-Age Support: Cross-country Evidence", Social, Employment and Migration Working Paper, OECD, Paris.

OECD (2005), Pensions at a Glance: Public Policies across OECD Countries, Paris.

OECD (2006), Taxing Wages, Paris.

OECD (2007), Benefits and Wages, Paris.

Queisser, M. and E.R. Whitehouse (2006),"Neutral or Fair? Actuarial Concepts and Pension-System Design", Social, Employment and Migration Working Paper No. 40, OECD, Paris.

Whitehouse, E.R. (2000), “Administrative Charges for Funded Pensions: Measurement Concepts, International Comparison and Assessment”, Journal of Applied Social Science Studies, Vol. 120, No. 3, pp. 311-361.

Whitehouse, E.R. (2001), “Administrative Charges for Funded Pensions: Comparison and Assessment of 13 Countries", Private Pension Systems: Administrative Costs and Reforms, Private Pensions Series, Vol. 3, OECD, Paris.

Whitehouse, E.R. (2006), Pensions Panorama: Retirement-Income Systems in 53 Countries, World Bank, Washington, DC. 


\section{PART I}

\section{Comparing Pension Policies of OECD Countries}

This part starts with an overview of the different schemes that together make up national retirement-income systems. A summary of the key features of pension systems - the parameters and rules - follows. The main empirical results, consisting of eight indicators that are calculated using the OECD pension models, are then presented.

The first two indicators are both replacement rates; that is, the ratio of pension benefits to individual earnings. These are given in gross and net terms, taking account of taxes and contributions paid on earnings and on retirement incomes. There are also two sensitivity analyses of the gross replacement rate: gross pension replacement rates with entry at age 25; and gross pension replacement rates with different rates of return.

The next two indicators are based on pension wealth, again in gross and net terms. Pension wealth, unlike replacement rates, reflects differences in pension ages, indexation of pensions in payment and national life expectancy.

The balance between the two core objectives of pension system - adequacy and insurance - is explored by the next pair of indicators, on the progressivity of the pension benefit formula and the link between pension and earnings.

The final two indicators are: weighted averages - pension levels and pension wealth; and structure of the pension package. They summarise the pension system as it affects individuals across the earnings distribution. 



\section{Overview of Retirement-Income Provision}

\section{$\mathrm{O}$}

ECD countries' retirement-income regimes are diverse and often involve a number of different programmes. As a result, classifying pension systems and different retirementincome schemes is difficult. The taxonomy used here, building on earlier work (OECD, 2004, 2005a), is based on the role and objective of each part of the pension system. The framework consists of two mandatory "tiers": a redistributive part and an insurance part. Redistributive components of pension systems are designed to ensure that pensioners achieve some absolute, minimum standard of living. Insurance components are designed to achieve some target standard of living in retirement compared with that when working. Voluntary provision, be it individual or employer-provided, makes up a third tier. Within these tiers, schemes are classified further by their provider (public or private) and the way benefits are determined (defined benefit or defined contribution, for example).

Table I.1 shows the diverse structure of pension systems in OECD countries. The table looks at schemes that might affect people who have spent all or most of their careers covered by the national pension system (and so excludes, for example, safety-net programmes that affect only or mainly people with large gaps in their contribution histories).

All OECD countries have safety nets that aim to prevent poverty in old age. All of these programmes, here called "first-tier, redistributive schemes", are provided by the public sector. There are three main types.

With basic-pension schemes, the benefit is either flat rate (the same amount is paid to every retiree) or it depends only on years of work, but not on past earnings. Additional income does not change the value of basic pensions. Thirteen countries have a basic pension scheme or other provisions with a similar effect.

The other two kinds of first-tier retirement-income programmes target payments on older people with low incomes. These are distinguished by the way in which benefits are targeted.

Resource-tested plans pay a higher benefit to poorer pensioners and reduced benefits to better-off retirees. The value of benefits depends either on income from other sources or on both income and assets. Some countries provide a safety net for older people through general social-assistance benefits. There are 16 OECD countries with resource-tested programmes likely to affect low earners who spend all or most of their careers in the national pension system.

Minimum pensions, found in 14 countries, are similar to resource-tested plans since they also aim to prevent pensions from falling below a certain level. The difference lies in 
Table I.1. Structure of pension systems in OECD countries

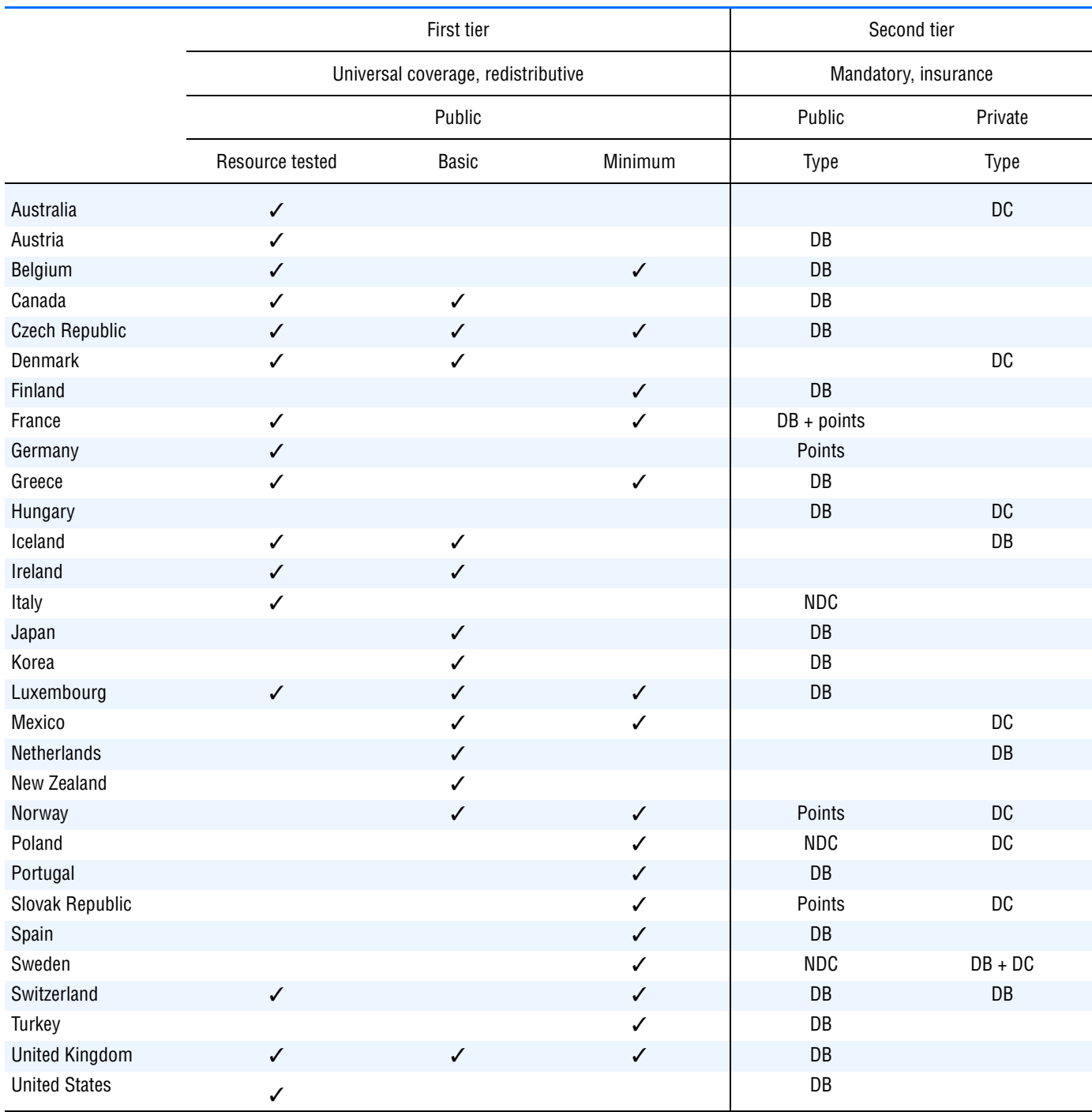

$\mathrm{DB}=$ defined benefit.

$\mathrm{DC}=$ defined contribution.

NDC = notional accounts

Source: Information provided by national authorities. See $\operatorname{OECD}(2004,2005 \mathrm{a})$ for a more detailed definition of these terms.

the way in which the value of entitlements is determined. Minimum pensions take account only of pension income, often from a single pension scheme, and are not affected by income from other savings or assets. Minimum credits in earnings-related schemes, such as those in Belgium and the United Kingdom, have a similar effect: benefits for workers with very low earnings are calculated as if the worker had earned at a higher level.

The second tier in this typology of pension schemes plays an "insurance" role. It aims to provide retirees with an adequate income relative to their previous earnings, not just a poverty-preventing absolute standard of living. Like the first tier, it is mandatory. Only Ireland and New Zealand do not have mandatory, second-tier provision.

Some 16 OECD countries have public, defined-benefit (DB) plans, making them the most common form of pension-insurance provision. In DB schemes, the amount a pensioner will receive depends on the number of years of contributions made throughout 
the working life and on some measure of individual earnings from work. Four countries have "points" schemes: the French occupational plans and the German, Norwegian and Slovak public schemes. Workers earn pension points based on their individual earnings for each year of contributions. At retirement, the sum of pension points is multiplied by a pension-point value to convert them into a regular pension payment.

Four countries have private occupational DB plans. In the Netherlands and Sweden the DB nature is explicit. In Iceland and Switzerland, the government sets the contribution rate, a minimum rate of return and the annuity rate at which the accumulation is converted into a pension, policies that together define the pension benefit.

The next most common form of pension-insurance provision is the definedcontribution (DC) plan. In these schemes, contributions flow into an individual account and the accumulation of contributions and investment returns is usually converted into a pension-income stream at retirement. DC schemes are organised in different ways. In Australia, employers must cover their workers while in Hungary, Mexico and Poland, workers choose a pension provider without employer involvement. In Sweden, only a small contribution goes into the mandatory individual accounts with additional DC provision for most workers under the quasi-mandatory occupational schemes.

There are also notional-accounts (NDC) schemes: the public pension plans of Italy, Poland and Sweden. These are schemes which record each worker's contributions in an individual account and apply a rate of return to the accounts. The accounts are "notional" in that both the incoming contributions and the interest charged to them exist only on the books of the managing institution. At retirement, the accumulated notional capital in each account is converted into a stream of pension payments using a formula based on life expectancy. 


\section{Key Features of Pension-System Design}

$\mathrm{T}_{\mathrm{h}}$

he main features of OECD member countries' pension systems are summarised in Table I.2 below. These follow the typology of the previous section, dividing the pension system into two tiers. The summary necessarily leaves out much of the institutional details. More complete descriptions are provided in the country studies (Part III).

\section{First-tier, redistributive schemes}

The level of benefits under first-tier, redistributive schemes is expressed as a percentage of average earnings in each country (see the discussion of average earnings data in the section on methodology above).

In the cases of minimum pensions and basic schemes, the benefit entitlement is shown for a worker who enters at age 20 and works without interruption until he reaches the standard pension eligibility age. In most OECD countries, this is age 65 as shown in the last lines of Table I.2. Only full-career workers with very low earnings will be eligible for the resource-tested programmes; the majority of beneficiaries will be those with short and interrupted contribution histories. The final row shows the total, first-tier benefit for a fullcareer worker. In some cases, workers can receive several different types of first-tier benefits, while in other cases they are only eligible for one programme.

The average minimum retirement benefit across OECD countries is a little under $29 \%$ of average earnings.

\section{Second-tier, insurance schemes}

The information on the second, insurance tier is shown separately for earningsrelated and defined-contribution (DC) plans.

The information on earnings-related schemes begins with the scheme type: defined benefit (DB), points or notional accounts (NDC). The main parameter accounting for differences in the value of these schemes is the accrual rate per year of contribution, that is, the rate at which a worker earns benefit entitlements for each year of coverage. The accrual rate is expressed as a percentage of the earnings that are "covered" by the pension scheme. Most pension schemes cover only part of workers' earnings to calculate pension benefits.

For points systems, the effective accrual rate shown in Table I.2 is the ratio of the cost of a pension point to the pension-point value, expressed as percentage of individual earnings. This, like the accrual rate in DB schemes, gives the benefit earned each year as a proportion of earnings in that year. In notional-accounts schemes, the effective accrual rate is calculated in a similar way to obtain the annual pension entitlement as a proportion of earnings in a given year. The calculations, which depend on the contribution rate, notional interest rate and annuity factors, are described in detail in Pensions at a Glance (OECD, 2005a). 
In a little under half of the countries with earnings-related plans (of all three types), the accrual rates are linear. In the other countries, the pension benefit earned for each year of coverage varies, either with individual earnings, with the number of years of contributions or with individual age.

In eight cases, the accrual rate varies with earnings (indicated in Table I.2 by [w]). In the public schemes of the Czech Republic, Switzerland, Portugal and the United States, the pattern is progressive, giving higher replacement rates to lower-income workers. In the United Kingdom, the accrual rates are U-shaped, highest for low earners, then smaller, then higher again. In the occupational plans of France and Sweden, the benefits are designed to offset the redistribution in the public scheme; they pay a higher replacement rate to high earners on their pay above the ceiling of the public plan.

In the occupational plans of Finland and Switzerland, pension accrual increases with age (shown as [a]).

Two countries have accrual rates that vary with length of service ([y]). In Luxembourg, the accrual rate increases for people with a longer contribution history. In Spain, there are three accrual rates. The pattern is the reverse of that in Luxembourg: the highest accrual rate is for the first few years of coverage and the lowest for later years in longer contribution histories.

\section{Defined-contribution plans}

The key parameter for DC plans is the proportion of earnings that must be paid into the individual account by employees, employers or the government. The average contribution rate in the eight countries with a mandatory DC plan is $7.25 \%$. The largest contribution is in Denmark, made up of $1 \%$ to the special pension and an average of $10.8 \%$ to quasi-mandatory, occupational schemes. In Australia and the Slovak Republic, the contribution rate is $9 \%$. Norway has recently made coverage of DC occupational schemes mandatory, but the contribution rate is only $2 \%$. In Sweden, employees must contribute $2.5 \%$ of earnings to a DC account and white-collar, private sector workers are also covered by a DC scheme with a $2 \%$ contribution rate. The contribution rate is $6.5 \%$ in Mexico. The additional government contribution of $5.5 \%$ of the minimum wage is shown as a basic scheme because it is a flat amount for each year of service.

\section{Measuring earnings to calculate benefits}

DB pension entitlements depend on the past earnings of the individual worker but the way in which these are measured differs. Table I.2 shows whether lifetime average or a limited number of best or final years' salaries are used. It is important to remember that the information shown here relates to the long-term rules of the system: the averaging period is being changed in a number of countries (see the special chapter on pension reform).

By far the most common method is to use the full lifetime average of earnings to calculate benefits. This is the approach in 17 countries, with Canada, the Czech Republic and the United States averaging earnings over the great majority of the career (30-35 years). There are five exceptions. Final salaries will be used to calculate benefits in Greece, Spain and in the DB occupational scheme in Sweden. The public pension schemes of France and Norway will be based on the best 25 and 20 years' earnings respectively. 


\section{Valorisation}

Closely linked with the earnings measure is the policy of valorisation or revaluation, whereby past earnings are adjusted to take account of changes in living standards between the time pension rights accrued and the time they are claimed. (This is sometimes called pre-retirement indexation.) If benefits are based on the final year's salary, there is no need for valorisation. But it is necessary to protect the value of pension entitlements when benefits are based on earnings measured over a longer period. The uprating of the pensionpoint value and the notional interest rate in points and notional-accounts systems, respectively are the exact corollaries of valorisation in DB plans (see Queisser and Whitehouse, 2006, Box 4 for a detailed explanation).

The effect of valorisation policy on pension entitlements is large due to a "compoundinterest" effect. On the baseline economic assumptions used in this report - i.e., real wage growth of $2 \%$ and price inflation of $2.5 \%$ - prices valorisation for a full career (between age 20 and 65) results in a pension that would be $40 \%$ lower than a policy of full adjustment of earlier years' pay in line with economy-wide average earnings.

The most common practice - followed in 15 OECD countries - is to revalue earlier years' pay in line with the growth of average earnings in the economy. Belgium, France and Spain, however, revalue earnings only with price inflation, although the effect in Spain is relatively small because only the final 15 years' salary enters the benefit formula, compared with 25 years in the French public scheme and the lifetime average in Belgium and the French occupational plans. Finland, Portugal and Turkey revalue earlier years' earnings to a mix of price and wage inflation.

\section{Ceilings on pensionable earnings}

Most countries do not require high-income workers to contribute to the pension system on their entire earnings. Usually, a limit is set on the earnings used both to calculate contribution liability and pension benefits. This ceiling on the earnings covered by the pension system has an important effect on the structure, size and cost of second-tier schemes. The average ceiling on public pensions for 19 countries is $189 \%$ of average economy-wide earnings. (This average excludes eight countries where there is no public pension scheme for which a ceiling is relevant, such as basic or targeted programmes and three countries that have no ceiling on earnings eligible for a public pension.)

Table I.2 also shows ceilings for mandatory private pension systems and for the public, occupational plans in France and Finland. Of the nine countries with this type of programme, three have no ceiling: Finland, Iceland and the Netherlands. The ceilings of the occupational plans in France and Sweden are three and 2.8 times respectively the cap on pensionable earnings in the public programme (equivalent to over 3 times average economywide earnings). The ceiling on mandatory contributions to the defined-contribution (DC) plan in Mexico is also relatively high.

\section{Pension eligibility ages}

The majority of OECD member countries have a standard retirement age of 65 for men. Pension eligibility ages for women are still lower in several countries but, in most of these, they will be equalised gradually with those of men (in Belgium, Hungary and the United Kingdom, for example). Iceland, Norway and the United States have a standard pension age of 67 and other countries, such as Denmark, Germany and the United Kingdom, are also 
proposing increase pension age above 65 . France is the only OECD country which allows normal retirement at age 60. More than half of OECD countries, however, allow retirement before the normal pension age, although usually only with reduced benefits.

\section{Indexation of pensions in payment}

Indexation refers to the policy for the up-rating of the value of the payment from the point of claim of the pension benefit onwards. Pension benefits are usually adjusted in line with an index of consumer prices. Some countries have mixed uprating of benefits, to a combination of price inflation and wage growth: the Czech Republic, Finland, Hungary, the Slovak Republic and Switzerland.

Austria, Greece, Italy and Portugal have adopted progressive indexation mechanisms, which give higher increases to low pensions than to higher benefits. Italy provides full price adjustment for low pensions and $90 \%$ or $75 \%$ of price inflation to higher pensions. In Portugal, pensions are adjusted to a mix of price inflation and GDP growth; the exact increases depend both on the level of pensions and on GDP growth rates.

\section{Indexation of pension-system parameters}

Indexation affects not only pensions in payment but also the parameters of pension systems. In resource-tested and basic pension schemes, the adjustment of benefit levels to the point when they are first claimed is more important than the adjustment of benefits in payment.

Take the United Kingdom's basic pension scheme as an example. This has been linked to prices since 1981 , when it was worth $24 \%$ of average earnings. Today, it is worth just $15 \%$ of average earnings. The change in indexation procedure reduced the entitlements not only of pensioners but also the benefits of all future workers. If the procedure continues, then the basic pension for new entrants will be worth just $6.4 \%$ of average earnings when they retire in 45 years' time, just $40 \%$ of its value relative to earnings now. (This calculation uses the baseline real-earnings-growth assumption of $2 \%$ per year.)

Canada and Sweden also link their resource-tested schemes to prices (while the United Kingdom now links this to average earnings). The implication, over the long periods involved in pension policy, is that these programmes will all but disappear. For new entrants, the minimum retirement income in 45 years time would be just $12 \%$ of average earnings in Canada and $14 \%$ in Sweden. It is difficult to believe that it will be politically possible to pay such low incomes to poor, old people. As a result, these policies are unlikely to be sustainable or, indeed, sustained.

Therefore, the modelling in this report explicitly assumes that these benefits and parameters are linked to average earnings, and not prices, even though this is what legislation specifies. Obviously this assumption has a big effect on the results when calculating the value of the pension promise. 


\section{Table I.2. Summary of pension-scheme parameters and rules}

\begin{tabular}{|c|c|c|c|c|c|c|c|c|c|c|}
\hline & Australia & Austria & Belgium & Canada & $\begin{array}{l}\text { Czech } \\
\text { Republic }\end{array}$ & Denmark & Finland & France & Germany & Greece \\
\hline \multicolumn{11}{|l|}{ First tier } \\
\hline \multicolumn{11}{|l|}{ ( $\%$ average earnings) } \\
\hline Resource-tested & 25 & 28 & 22 & 17 & 26 & 18 & 19 & 32 & 19 & 11 \\
\hline Basic & - & - & - & 14 & 8 & 18 & - & - & - & - \\
\hline Minimum & - & - & $34^{1}$ & - & 12 & - & - & 23 & - & 34 \\
\hline Overall entitlement & 25 & 28 & 34 & 31 & 26 & 36 & 19 & 32 & 19 & 34 \\
\hline \multicolumn{11}{|l|}{ (full-career worker) } \\
\hline \multicolumn{11}{|l|}{ Second tier } \\
\hline \multicolumn{11}{|l|}{ Earnings-related } \\
\hline Type & None & DB & DB & DB & $\mathrm{DB}$ & None & $\mathrm{DB}$ & DB/Points & Points & $\mathrm{DB}$ \\
\hline Accrual rate & - & 1.78 & 1.33 & 0.63 & $0.45[w]^{2}$ & - & $1.5[\mathrm{a}]^{4}$ & $1.75[w]^{5,6}$ & 1.00 & $2.57^{5}$ \\
\hline \multicolumn{11}{|l|}{ (\% indiv. earnings) } \\
\hline Earnings measure & - & 40 & L & b34 & $\mathrm{f} 30$ & - & L & b25/L & $\mathrm{L}$ & f5 \\
\hline Valorisation & - & $w^{15}$ & $\mathrm{p}$ & w & w & - & $80 w / 20 p$ & $p / p$ & $w^{16}$ & 17 \\
\hline Indexation & - & $d$ & $\mathrm{p}$ & $p$ & $33 w / 67 p$ & - & $20 w / 80 p$ & $\mathrm{p} / \mathrm{p}$ & $w^{16}$ & $d$ \\
\hline \multicolumn{11}{|l|}{ Defined contribution } \\
\hline Contribution rate & 9 & - & - & - & - & 11.8 & - & - & - & \\
\hline \multicolumn{11}{|l|}{ (\% indiv. earnings) } \\
\hline \multicolumn{11}{|l|}{ Ceilings } \\
\hline \multicolumn{11}{|l|}{ (\% average earnings) } \\
\hline Public & - & 147 & 117 & 96 & None & - & - & 101 & 151 & $275^{7}$ \\
\hline Private/occupational & 257 & - & - & - & - & - & None & 302 & - & - \\
\hline \multicolumn{11}{|l|}{ Pension age } \\
\hline Normal & 65 & 65 & 65 & 65 & 63 & 65 & 65 & 60 & 65 & 65 \\
\hline (women) & & & & & $(59-63)^{3}$ & & & & & \\
\hline Early & 55 & & 60 & 60 & 60 & & 62 & & 63 & 55 \\
\hline (women) & & & & & $(56-60)^{3}$ & & & & & \\
\hline
\end{tabular}

Parameters are for 2004 but include all legislated changes that take effect in the future. For example, some countries are increasing pension ages and extending the earnings measure for calculating benefits; pension ages for women are shown only if different from those for men. Early pension ages are shown only where relevant.

$-=$ not relevant; $[\mathrm{a}]$ = varies with age; $[\mathrm{w}]$ = varies with earnings; $[\mathrm{y}]=$ varies with years of service.

$\mathrm{b}=$ number of best years; $\mathrm{f}=$ number of final years; $\mathrm{L}=$ lifetime average.

$\mathrm{d}=$ discretionary indexation; $\mathrm{fr}=$ valorisation at a statutorily fixed rate; $\mathrm{p}=$ valorisation/indexation with prices; $\mathrm{W}=$ valorisation/indexation with average earnings; GDP = linked to gross domestic product.

$\mathrm{DB}=$ defined benefit; $\mathrm{DC}=$ defined contribution; NDC = notional accounts.

1. Belgium, Slovak Republic, United Kingdom: minimum benefit calculated from minimum credit.

2. Czech Republic, Portugal, United States: higher accrual rates on lower earnings, lower accruals on higher earnings.

3. Czech Republic: pension ages for women vary with number of children.

4. Finland: higher accrual rates at older ages.

5. France, Greece, Sweden: data shown combines two different programmes.

6. France, Sweden: higher accrual rate on higher earnings under occupational plans.

7. Greece: effective ceiling calculated from maximum pension. 
Table I.2. Summary of pension-scheme parameters and rules (cont.)

\begin{tabular}{|c|c|c|c|c|c|c|c|c|c|c|}
\hline & Hungary & Iceland & Ireland & Italy & Japan & Korea & Luxembourg & Mexico & Netherlands & $\begin{array}{c}\text { New } \\
\text { Zealand }\end{array}$ \\
\hline \multicolumn{11}{|l|}{ First tier } \\
\hline \multicolumn{11}{|l|}{ (\% average earnings) } \\
\hline Resource-tested & - & $18^{8}$ & 27 & - & - & - & - & - & - & - \\
\hline Basic & - & 9 & 30 & - & 16 & 30 & 10 & $7.0 / 4.2^{10}$ & 31 & 40 \\
\hline Minimum & 22 & - & - & - & - & - & 39 & 26 & - & - \\
\hline Overall entitlement & 22 & 27 & 30 & 22 & 16 & 30 & 39 & 26 & 31 & 40 \\
\hline \multicolumn{11}{|l|}{ (full-career worker) } \\
\hline \multicolumn{11}{|l|}{ Second tier } \\
\hline \multicolumn{11}{|l|}{ Earnings-related } \\
\hline Type & DB & DB & None & NDC & $\mathrm{DB}$ & DB & DB & None & $\mathrm{DB}$ & None \\
\hline Accrual rate & 1.22 & 1.40 & - & 1.75 & 0.55 & 1.5 & $1.85[y]^{9}$ & - & $1.75^{11}$ & - \\
\hline \multicolumn{11}{|l|}{ (\% indiv. earnings) } \\
\hline Earnings measure & $\mathrm{L}$ & L & - & $\mathrm{L}$ & L & L & L & - & $\mathrm{L}^{14}$ & - \\
\hline Valorisation & w & $\mathrm{fr}$ & - & GDP & w & w & w & - & w & - \\
\hline Indexation & $50 w / 50 p$ & $\mathrm{p}$ & - & $p^{18}$ & $p$ & $\mathrm{p}$ & w & - & w & - \\
\hline \multicolumn{11}{|l|}{ Defined contribution } \\
\hline Contribution rate & 8 & - & - & - & - & - & - & $6.5^{10}$ & - & - \\
\hline \multicolumn{11}{|l|}{ (\% indiv. earnings) } \\
\hline \multicolumn{11}{|l|}{ Ceilings } \\
\hline \multicolumn{11}{|l|}{ (\% average earnings) } \\
\hline Public & 220 & - & - & 370 & 150 & 160 & 215 & - & - & - \\
\hline Private/occupational & 220 & None & - & - & - & - & - & 377 & None & - \\
\hline \multicolumn{11}{|l|}{ Pension age } \\
\hline Normal & 62 & 67 & 66 & 65 & 65 & 65 & 65 & 65 & 65 & 65 \\
\hline (women) & & & & $(60)$ & & & & 60 & & \\
\hline Early & & & 65 & 60 & 60 & 60 & 57 & & 60 & \\
\hline (women) & & & & & & & & & & \\
\hline
\end{tabular}

8. Iceland: includes two different programmes.

9. Luxembourg: higher accrual rate for longer contribution periods.

10. Mexico: additional contribution of $5.5 \%$ of minimum wage is shown as a basic pension. The lower value of the annuity calculated is for women (because women retire earlier than men).

11. Netherlands: accrual rate varies between occupational schemes.

12. Norway: lower accrual rate on higher earnings.

13. Spain: higher accrual rate on early years of service and lower on later years.

14. Netherlands: earnings measure is average salary for around two-thirds of occupational plans and final salary for one-third.

15. Austria: valorisation assumed to move to earnings as the averaging period for the earnings measure is extended.

16. Germany: valorisation can be reduced by any increase in contribution rates and for the potential contribution to private pensions. Indexation can be reduced by any increase in contributions.

17. Greece: valorisation in line with pension increases for public-sector workers

18. Italy: indexation is fully to prices for low pensions, $90 \%$ of prices or $75 \%$ of prices for higher pensions. 
Table I.2. Summary of pension-scheme parameters and rules (cont.)

\begin{tabular}{|c|c|c|c|c|c|c|c|c|c|c|}
\hline & Norway & Poland & Portugal & $\begin{array}{l}\text { Slovak } \\
\text { Republic }\end{array}$ & Spain & Sweden & Switzerland & Turkey & $\begin{array}{l}\text { United } \\
\text { Kingdom }\end{array}$ & $\begin{array}{l}\text { United } \\
\text { States }\end{array}$ \\
\hline \multicolumn{11}{|l|}{ First tier } \\
\hline \multicolumn{11}{|l|}{ ( $\%$ average earnings) } \\
\hline Resource-tested & 33 & - & 20 & - & - & 34 & 24 & 6 & 20 & 22 \\
\hline Basic & 18 & - & - & - & - & - & - & - & 15 & - \\
\hline Minimum & - & 23 & 44 & $22^{1}$ & 30 & - & 18 & 28 & $15^{1}$ & - \\
\hline Overall entitlement & 33 & 23 & 44 & 22 & 30 & 34 & 24 & 28 & 30 & 22 \\
\hline \multicolumn{11}{|l|}{ (full-career worker) } \\
\hline \multicolumn{11}{|l|}{ Second tier } \\
\hline \multicolumn{11}{|l|}{ Earnings-related } \\
\hline Type & Points & NDC & DB & Points & DB & NDC/DB & $\mathrm{DB}$ & DB & DB & $\mathrm{DB}$ \\
\hline Accrual rate & $1.05[w]^{12}$ & 0.67 & {$[w]^{2}$} & 1.16 & {$[y]^{13}$} & $1.18[w]^{5,6}$ & {$[\mathrm{w} / \mathrm{a}]$} & 2.0 & {$[w]^{21}$} & {$[w]^{2}$} \\
\hline \multicolumn{11}{|l|}{ (\% indiv. earnings) } \\
\hline Earnings measure & b20 & $\mathrm{L}$ & L & L & $\mathrm{f} 15$ & $L / f$ & L & $\mathrm{L}$ & L & b35 \\
\hline Valorisation & w & $w^{19}$ & $25 w / 75 p$ & w & $p$ & w & w & $50 w / 50 p$ & w & $w^{22}$ \\
\hline Indexation & w & $p^{19}$ & $\mathrm{p} / G D P^{20}$ & $50 w / 50 p$ & $p$ & $w-1.6$ & $50 w / 50 p$ & $p$ & $\mathrm{p}$ & $p$ \\
\hline \multicolumn{11}{|l|}{ Defined contribution } \\
\hline Contribution rate & 2 & 7.3 & - & 9 & - & $4.5^{5}$ & - & - & - & - \\
\hline \multicolumn{11}{|l|}{ (\% indiv. earnings) } \\
\hline \multicolumn{11}{|l|}{ Ceilings } \\
\hline \multicolumn{11}{|l|}{ ( $\%$ average earnings) } \\
\hline Public & 219 & 230 & None & 300 & 165 & 132 & 108 & 245 & 115 & 290 \\
\hline Private/occupational & - & - & - & - & - & 367 & 108 & - & - & - \\
\hline \multicolumn{11}{|l|}{ Pension age } \\
\hline Normal & 67 & 65 & 65 & 62 & 65 & 65 & 65 & 65 & 65 & 67 \\
\hline (women) & & (60) & & & & & (64) & & & \\
\hline Early & & & 55 & & 60 & 61 & 63 & & & 62 \\
\hline (women) & & & & & & & (62) & & & \\
\hline
\end{tabular}

19. Poland: valorisation to real wage bill growth but at least price inflation. Indexation has been $80 \%$ prices and $20 \%$ wages but moved to prices from 2005.

20. Portugal: indexation will be higher relative to prices for low pensions and vice versa. Indexation will be more generous the higher is GDP growth.

21. United Kingdom: accrual rate highest for low earnings, then lower then higher again.

22. United States: earnings valorisation to age 60; no adjustment from 60 to 62; prices valorisation from 62 to 67.

Source: Information provided by national authorities and OECD calculations. 


\section{Retirement-Income Indicators}

The first two indicators are both replacement rates; that is, the ratio of pension benefits to individual earnings. These are given in gross and net terms, taking account of taxes and contributions paid on earnings and on retirement incomes. There are also two sensitivity analyses of the gross replacement rate: gross pension replacement rates with entry at age 25; and gross pension replacement rates with different rates of return.

The next two indicators are based on pension wealth, again in gross and net terms. Pension wealth, unlike replacement rates, reflects differences in pension ages, indexation of pensions in payment and national life expectancy.

The balance between the two core objectives of pension system - adequacy and insurance - is explored by the next pair of indicators, one on the progressivity of the pension benefit formulae and the other on the link between pension and earnings.

The final two indicators are: weighted averages - pension levels and pension wealth; and structure of the pension package. They summarise the pension system as it affects individuals across the earnings distribution. 


\section{Definition and measurement}

The gross replacement rate is defined as gross pension entitlement divided by gross pre-retirement earnings. It is shown here at median earnings and at 0.5, 0.75, 1, 1.5 and 2 times average (mean) earnings.

The old-age pension replacement rate is a measure of how effectively a pension system provides income during retirement to replace earnings, the main source of income prior to retirement. Often, the replacement rate is expressed as the ratio of the pension over the final earnings before retirement. However, the indicator used here shows the pension benefit as a share of individual lifetime average earnings (re-valued in line with economy-wide earnings growth). Under the baseline assumptions, workers earn the same percentage of economy-wide average earnings throughout their career. In this case, lifetime average re-valued earnings and individual final earnings are identical. If people move up the earnings distribution as they get older, then their earnings just before retirement will be higher than they were on average over their lifetime and replacement rates calculated on individual final earnings will be lower.

For workers at average earnings, the average for the OECD countries of the gross replacement rate from mandatory pensions is $58.7 \%$. There is substantial variation across countries, with Greece and Luxembourg at the top of the range, offering replacement rates of more than $90 \%$. The lowest replacement rates for average earners are paid in the United Kingdom, Ireland and Japan, while countries such as Norway and Switzerland are in the middle of the range. Replacement rates from mandatory schemes tend to be the lowest in the six mainly English-speaking countries, averaging $38.5 \%$ for workers on mean earnings. They are the highest in the five Southern European nations - Greece, Italy, Portugal, Spain and Turkey - averaging $74.3 \%$.

Low earners - workers earning only half the mean - have higher replacement rates than median or mean earners: on average, $73 \%$. This reflects the fact that most countries attempt to protect lowincome workers from old-age poverty. The crosscountry variation of replacement rates at this earnings level is much lower than it is for pensions of those who earn twice the average. The highest gross replacement rate for low earners is found in Denmark at $120 \%$, which means that full-career workers with permanently low earnings have more money when they retire than when they were working. The lowest rate is observed in Germany where full-career workers on half average earnings receive only a $40 \%$ replacement rate.
At high earnings, Greece again offers the highest pensions, reflecting both a high accrual rate and a high ceiling on pensionable earnings. While most other countries have lower ceilings and therefore lower replacement rates for high earners, the Greek system offers the same rate to full-career workers up to $275 \%$ of average earnings. In contrast, high earners receive the lowest benefits relative to their previous earnings in Ireland. The variation across countries in replacement rates for high earners is much greater than it is for people on low or average pay.

Finally, the table also presents pension replacement rates for women in the four countries where these differ from those of men (due to a lower pension eligibility age for women than for men). The difference between the sexes in replacement rates is particularly stark in two of the countries with defined-contribution schemes: Mexico and Poland. In both countries, normal pension age for women is 60 while for men it is 65 . This means that women accumulate capital in the individual pension accounts over a shorter period. It also means that women spend a longer period in retirement over which pension capital must be spread. As a result, replacement rates at average earnings are around one third smaller for women than they are for men. In Mexico, the differential between men and women's replacement rates is larger than in Poland because annuities are calculated using sex-specific mortality rates rather than unisex life tables. 
GROSS PENSION REPLACEMENT RATES

\section{Gross replacement rates by earnings}

\begin{tabular}{|c|c|c|c|c|c|c|c|c|c|c|c|c|c|}
\hline & \multirow{2}{*}{$\begin{array}{c}\text { Median } \\
\text { earner }\end{array}$} & \multicolumn{5}{|c|}{ Individual earnings, multiple of mean } & & \multirow{2}{*}{$\begin{array}{c}\text { Median } \\
\text { earner }\end{array}$} & \multicolumn{5}{|c|}{ Individual earnings, multiple of mean } \\
\hline & & 0.5 & 0.75 & 1 & 1.5 & 2 & & & 0.5 & 0.75 & 1 & 1.5 & 2 \\
\hline Men & & & & & & & Men (cont.) & & & & & & \\
\hline Australia & 47.9 & 70.7 & 52.3 & 43.1 & 33.8 & 29.2 & New Zealand & 46.8 & 79.5 & 53.0 & 39.7 & 26.5 & 19.9 \\
\hline Austria & 80.1 & 80.1 & 80.1 & 80.1 & 78.5 & 58.8 & Norway & 60.0 & 66.4 & 61.2 & 59.3 & 50.2 & 42.7 \\
\hline Belgium & 40.7 & 57.3 & 40.9 & 40.4 & 31.3 & 23.5 & Poland & 61.2 & 61.2 & 61.2 & 61.2 & 61.2 & 61.2 \\
\hline Canada & 49.5 & 75.4 & 54.4 & 43.9 & 29.6 & 22.2 & Portugal & 54.3 & 70.4 & 54.5 & 54.1 & 53.4 & 52.7 \\
\hline Czech Rep. & 54.3 & 78.8 & 59.0 & 49.1 & 36.4 & 28.9 & Slovak Rep. & 56.7 & 56.7 & 56.7 & 56.7 & 56.7 & 56.7 \\
\hline Denmark & 83.6 & 119.6 & 90.4 & 75.8 & 61.3 & 57.1 & Spain & 81.2 & 81.2 & 81.2 & 81.2 & 81.2 & 67.1 \\
\hline Finland & 63.4 & 71.3 & 63.4 & 63.4 & 63.4 & 63.4 & Sweden & 63.7 & 79.1 & 66.6 & 62.1 & 64.7 & 66.3 \\
\hline France & 51.2 & 63.8 & 51.2 & 51.2 & 46.9 & 44.7 & Switzerland & 62.0 & 62.5 & 62.1 & 58.4 & 40.7 & 30.5 \\
\hline Germany & 39.9 & 39.9 & 39.9 & 39.9 & 39.9 & 30.0 & Turkey & 72.5 & 72.5 & 72.5 & 72.5 & 72.5 & 72.5 \\
\hline Greece & 95.7 & 95.7 & 95.7 & 95.7 & 95.7 & 95.7 & UK & 34.4 & 53.4 & 37.8 & 30.8 & 22.6 & 17.0 \\
\hline Hungary & 76.9 & 76.9 & 76.9 & 76.9 & 76.9 & 76.9 & US & 43.6 & 55.2 & 45.8 & 41.2 & 36.5 & 32.1 \\
\hline Iceland & 80.1 & 109.9 & 85.8 & 77.5 & 74.4 & 72.9 & & & & & & & \\
\hline Ireland & 38.2 & 65.0 & 43.3 & 32.5 & 21.7 & 16.2 & OECD & 60.8 & 73.0 & 62.7 & 58.7 & 53.7 & 49.2 \\
\hline Italy & 67.9 & 67.9 & 67.9 & 67.9 & 67.9 & 67.9 & & & & & & & \\
\hline Japan & 36.8 & 47.8 & 38.9 & 34.4 & 29.9 & 27.2 & Women (whe & ifferent) & & & & & \\
\hline Korea & 72.7 & 99.9 & 77.9 & 66.8 & 55.8 & 45.1 & Italy & 52.8 & 52.8 & 52.8 & 52.8 & 52.8 & 52.8 \\
\hline Luxembourg & 90.3 & 99.8 & 92.1 & 88.3 & 84.5 & 82.5 & Mexico & 31.1 & 52.8 & 35.2 & 29.7 & 28.5 & 27.9 \\
\hline Mexico & 36.6 & 52.8 & 37.3 & 35.8 & 34.4 & 33.6 & Poland & 44.5 & 46.2 & 44.5 & 44.5 & 44.5 & 44.5 \\
\hline Netherlands & 81.7 & 80.6 & 81.5 & 81.9 & 82.4 & 82.6 & Switzerland & 62.6 & 62.8 & 62.6 & 59.1 & 41.2 & 30.9 \\
\hline
\end{tabular}

Source: OECD pension models.

Gross replacement rates by earnings

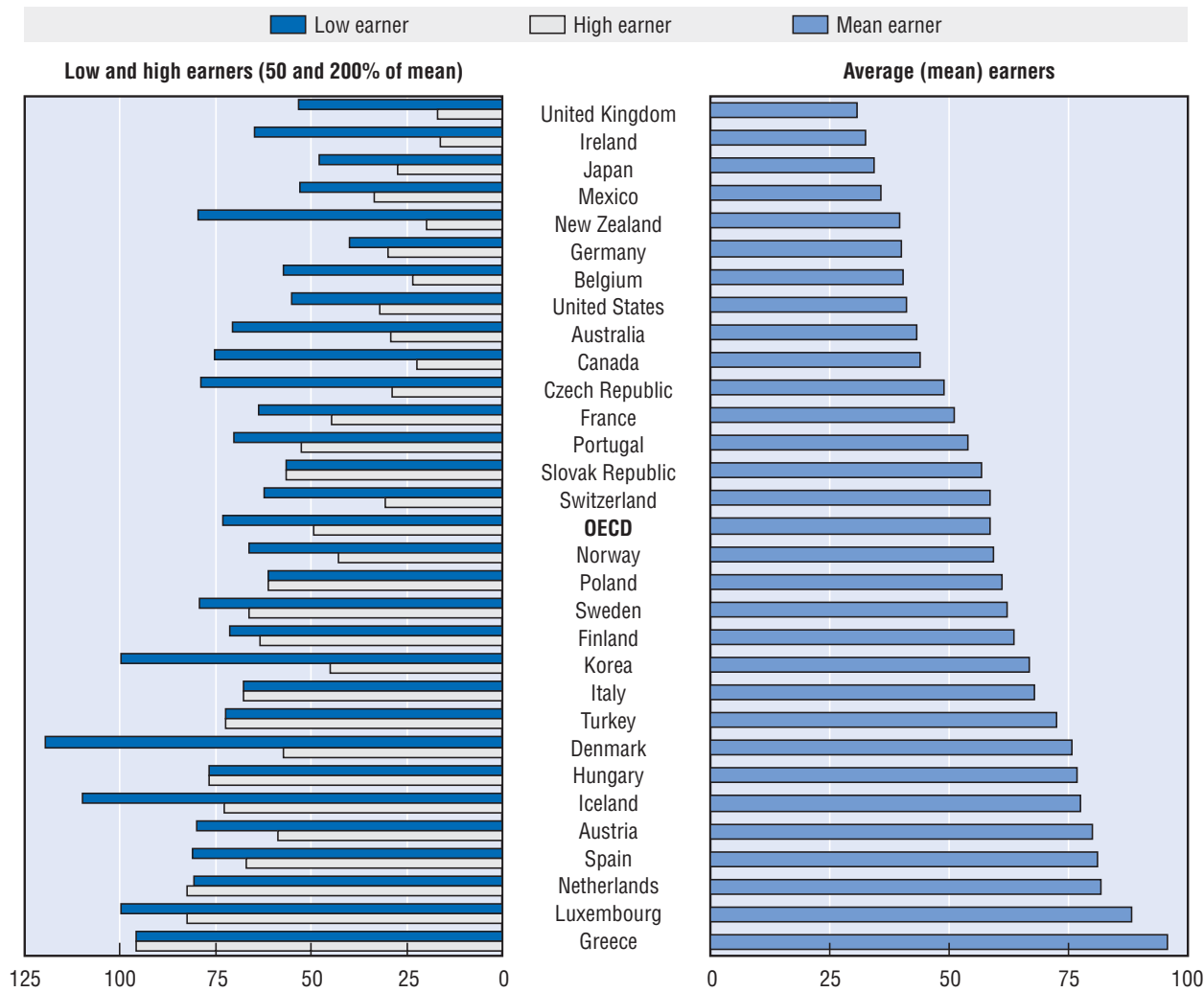

Note: Countries are ranked in order of gross pension replacement rates (GRR) of average earners, i.e. mean GRR in the chart. Source: OECD pension models. 


\section{Definition and measurement}

The net replacement rate is defined as the individual net pension entitlement divided by net pre-retirement earnings, taking account of personal income taxes and social security contributions paid by workers and pensioners. Otherwise, the definition and measurement of the net replacement rates are the same as for the gross replacement rate (see previous indicator). The results again cover full-career workers with median earnings and with $0.5,0.75,1,1.5$ and 2 times average (mean) earnings.

The personal tax system plays an important role in old-age support. Pensioners often do not pay social security contributions and, as personal income taxes are progressive and pension entitlements are usually lower than earnings before retirement, the average tax rate on pension income is typically less than the tax rate on earned income. In addition, most income tax systems give preferential treatment either to pension incomes or to pensioners, by giving additional allowances or credits to older people. Therefore, net replacement rates are usually higher than gross replacement rates.

For average (mean) earners, the net replacement rate across OECD countries is on average $70 \%$, which is some 11 percentage points higher than the gross replacement rate. The pattern of replacement rates across countries is different on a net rather than a gross basis.

For example, Belgium and Germany have considerably higher net replacement rates than gross. This is due, first, to favourable treatment of pension income under social security contributions and, secondly, because replacement rates are relatively low which, with strongly progressive personal income taxes, means that people pay much less in income tax when retired than they did when working. Germany is gradually withdrawing the current, very generous tax treatment of pension income but the differential between gross and net replacement rates will remain large even when this policy is fully in place.

In contrast with Belgium and Germany, New Zealand and Sweden move lower down the rankings measured on a net rather than a gross basis. This is because these countries tax pension income and earnings at very similar rates.

For low earners (with half of mean earnings), the average net replacement rate across OECD countries is $84 \%$. The effect of taxes and contributions on net replacement rates for low earners (at half average earnings) is more muted than for workers higher up the earnings scale. This is because low-income workers typically pay less in taxes and contributions than those on average earnings. In many cases, their retirement incomes are below the level of income-tax standard reliefs (allowances, credits, etc.). Thus, they are unable to benefit fully from additional concessions granted to pensions or pensioners under the income tax.

The difference for low earners is 11 percentage points, on average. Belgium and the Czech Republic have much higher replacement rates for low earners when measured on a net basis. In Mexico, the net replacement rate of low earners is below the gross rate because low-income workers pay less in tax than low-income pensioners (at the same level of income).

The differential between net and gross replacement rates for high earners is again 11 percentage points. But this implies that personal income taxes and social security contributions play a greater role than for average or low earners because net replacement rates - at $61 \%$ for high earners - are lower than for lower-income workers. The tax system therefore reduces the progressivity of retirement-income systems. The net replacement rate for workers earning twice the average is highest in Turkey where high-income workers also have the highest rates across the earnings range. Not surprisingly, the lowest rates are found in the flatrate pension systems of New Zealand and Ireland. In both countries, workers earning twice the average will receive pensions that amount to less than a quarter of their previous net earnings.

There are regional differences in the gap between gross and net replacement rates. For median earners in the EU-15 countries, net replacement rates are on average 11 percentage points higher than gross rates. In Nordic countries, the difference is smaller: net rates are less than 7 percentage points higher than gross rates. This is due to the fact that income taxes play a more important role in the Nordic countries than elsewhere: workers on mean earnings pay $33 \%$ of their wages in taxes and contributions in the Nordic countries compared with $26.5 \%$ for the OECD as a whole and still lower - 22.5\% - in the English-speaking countries. When it comes to low earners, however, the Nordic countries offer a $96 \%$ net replacement rate while the Anglophone OECD countries pay $76 \%$ of previous net earnings. 
NET PENSION REPLACEMENT RATES

\section{Net replacement rates by earnings}

\begin{tabular}{|c|c|c|c|c|c|c|c|c|c|c|c|c|c|}
\hline & \multirow{2}{*}{ Median earner } & \multicolumn{5}{|c|}{ Individual earnings, multiple of mean } & \multirow{2}{*}{\multicolumn{2}{|c|}{ Median earner }} & \multicolumn{5}{|c|}{ Individual earnings, multiple of mean } \\
\hline & & 0.5 & 0.75 & 1 & 1.5 & 2 & & & 0.5 & 0.75 & 1 & 1.5 & 2 \\
\hline Men & & & & & & & Men (cont.) & & & & & & \\
\hline Australia & 61.7 & 83.5 & 66.2 & 56.4 & 46.1 & 40.8 & New Zealand & 48.6 & 81.4 & 54.9 & 41.7 & 29.4 & 23.2 \\
\hline Austria & 90.6 & 90.4 & 90.6 & 90.9 & 89.2 & 66.4 & Norway & 70.0 & 77.1 & 71.2 & 69.3 & 62.5 & 55.1 \\
\hline Belgium & 64.4 & 77.3 & 65.5 & 63.0 & 51.1 & 40.7 & Poland & 74.8 & 74.5 & 74.8 & 74.9 & 75.0 & 77.1 \\
\hline Canada & 62.8 & 89.2 & 68.3 & 57.4 & 40.0 & 30.8 & Portugal & 67.4 & 81.6 & 66.0 & 69.2 & 72.2 & 73.7 \\
\hline Czech Rep. & 70.3 & 98.8 & 75.6 & 64.4 & 49.3 & 40.2 & Slovak Rep. & 71.9 & 66.4 & 70.6 & 72.9 & 75.4 & 76.7 \\
\hline Denmark & 94.1 & 132.7 & 101.6 & 86.7 & 77.0 & 72.2 & Spain & 84.2 & 82.0 & 83.9 & 84.5 & 85.2 & 72.4 \\
\hline Finland & 68.0 & 77.4 & 68.4 & 68.8 & 70.3 & 70.5 & Sweden & 66.2 & 81.4 & 69.2 & 64.0 & 71.9 & 73.9 \\
\hline France & 62.8 & 78.4 & 64.9 & 63.1 & 58.0 & 55.4 & Switzerland & 68.8 & 75.0 & 68.2 & 64.3 & 45.7 & 35.1 \\
\hline Germany & 57.3 & 53.4 & 56.6 & 58.0 & 59.2 & 44.4 & Turkey & 103.4 & 101.0 & 102.9 & 104.0 & 106.4 & 108.3 \\
\hline Greece & 111.1 & 113.6 & 111.7 & 110.1 & 110.3 & 107.0 & UK & 45.4 & 66.1 & 49.2 & 41.1 & 30.6 & 24.0 \\
\hline Hungary & 96.5 & 94.7 & 95.1 & 102.2 & 98.5 & 98.5 & US & 55.3 & 67.4 & 58.0 & 52.4 & 47.9 & 43.2 \\
\hline Iceland & 86.9 & 110.9 & 92.0 & 84.2 & 80.3 & 79.7 & & & & & & & \\
\hline Ireland & 44.4 & 65.8 & 49.3 & 38.5 & 29.3 & 23.5 & OECD & 72.1 & 83.8 & 74.0 & 70.1 & 65.4 & 60.7 \\
\hline Italy & 77.9 & 81.8 & 78.2 & 77.9 & 78.1 & 79.3 & & & & & & & \\
\hline Japan & 41.5 & 52.5 & 43.5 & 39.2 & 34.3 & 31.3 & Women & & & & & & \\
\hline Korea & 77.8 & 106.1 & 83.1 & 71.8 & 61.9 & 50.7 & Italy & 63.8 & 63.6 & 64.4 & 63.4 & 63.7 & 63.5 \\
\hline Luxembourg & 98.0 & 107.6 & 99.8 & 96.2 & 92.9 & 91.0 & Mexico & 32.2 & 50.3 & 35.7 & 31.7 & 32.3 & 33.2 \\
\hline Mexico & 37.9 & 50.3 & 37.8 & 38.3 & 39.0 & 40.0 & Poland & 55.3 & 57.5 & 55.3 & 55.2 & 55.0 & 56.4 \\
\hline Netherlands & 105.3 & 97.0 & 103.8 & 96.8 & 96.3 & 94.8 & Switzerland & 68.1 & 75.4 & 68.9 & 65.0 & 46.3 & 35.5 \\
\hline
\end{tabular}

Source: OECD pension models.

\section{Net replacement rates by earnings}
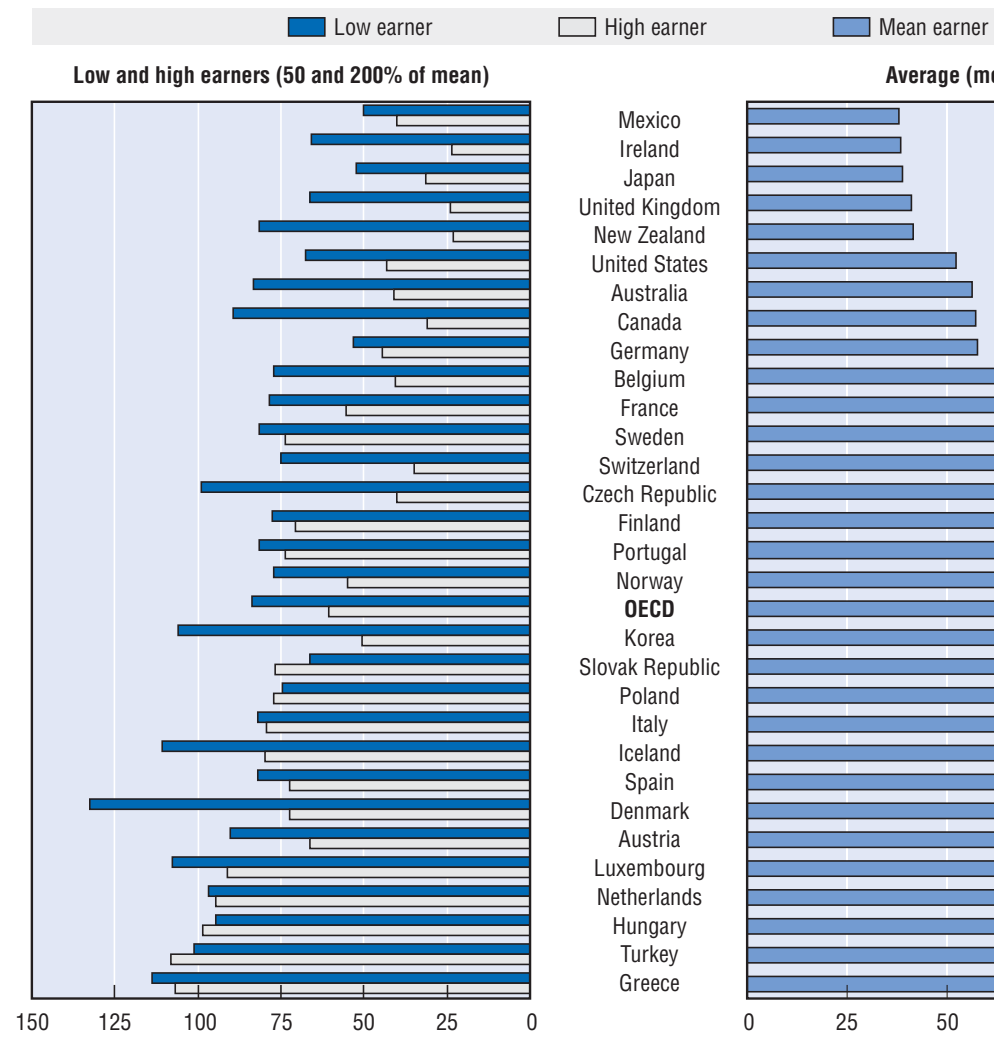

Note: Countries are ranked in order of net pension replacement rates (NRR) of average earners, i.e., mean NRR in the chart. Source: OECD pension models. 


\section{Definition and measurement}

The gross replacement rate is defined as gross pension entitlement divided by gross pre-retirement earnings. It is shown here at median earnings and a $0.5,0.75,1,1.5$, and 2 times average earnings levels. The rates are here shown for workers who enter the labour market at age 25 and work until the standard retirement age in the respective country. Until they reach age 25 , workers are assumed not to earn any pension entitlements.

Under the baseline assumptions used in this report, workers enter the labour market at age 20 and work until the standard retirement age. For the vast majority of OECD countries - with pension ages of 65 - this assumption results in a career length of 45 years. However, the lower pension age in France results in a full career length of 40 years and the higher ages in Iceland, Norway and the United States imply career lengths of 47 years. In the four countries that intend to retain different pension ages for men and women in the long term (see Table), career lengths are shorter for women than for men by between one and five years.

In reality, careers are currently shorter than the baseline assumption of 40-47 years: some workers start paid work later than age 20 and many spend time out of the labour market for various reasons. In addition, early retirement is still common in many OECD countries. As a sensitivity analysis, therefore, gross replacement rates are presented here for a shorter career. The alternative assumption is that workers enter the labour market at age 25. For the majority of countries, this results in a career length of 40 years. Again, it is shorter in France - 35 years and longer for Iceland, Norway and the United States -42 years. The table shows gross replacement rates from old-age pensions relative to earnings under this assumption.

For workers at average earnings, the average gross replacement rate for OECD countries for entry age 25 is $54.1 \%$, compared to $58.7 \%$ for labour-market entry at age 20 . Workers earning only half the average again receive higher replacement rates: on average $69.2 \%$, compared to $73 \%$ for entry at age 20 . At median earnings, i.e. at the earnings level both below and above which half of all workers are situated, the average OECD gross replacement is $56.3 \%$, compared to $60.8 \%$.

In Ireland, New Zealand, Portugal, Spain and the United States, replacement rates are the same for entry at ages 20 and 25. This is because Ireland and New Zealand have flat-rate pension systems. In Spain and the United States, the maximum replacement rate is reached after 35 years; therefore, contributing five years more does not change the pension benefit level except if these years are among the highest earnings.

The assumed age of labour-market exit is the normal pension age for each country in the analyses with entry at both age 20 and age 25. In France, however, benefits are more tightly tied to years of contributions than they are in most other countries. The first results in the table show the case of an individual working at ages 25-60, giving a replacement rate of $37.4 \%$ for an average earner, compared with $51.2 \%$ for an average earner with a career spanning ages 20 to 60 . Given the size of the penalty for retiring at 60 for workers entering at age 25 , the table also shows as a memorandum the results for a French worker contributing from age 25 to age 65 .

Are estimates of future pension entitlements based on this shorter career length "better" than those assuming a longer period? The first point that needs to be borne in mind is that the aim of all these estimates is not to predict future pensions; it is to describe how pension systems operate. Having said that, the shorter working career is certainly close to the experience of current pensioners. Whether this will be the case in the future is speculation. OECD (2006) suggests that after years or even decades of contracting, the average age of retirement in some countries has started to rise instead. (See also OECD, 2005b, indicator SS8).

More important for the purposes of this exercise is the fact that recent changes in the pension systems of many countries have extended credits for time out of the labour force. Child care, higher education, receipt of sickness, invalidity benefits and unemployment all result in periods being credited to an individual's contribution record in many countries. In the future therefore, it seems likely that if people do not have full careers when they reach retirement age, they nevertheless will have a variety of credits which will need to be taken into account. 
Gross replacement rates by earnings: entry at age 25

\begin{tabular}{|c|c|c|c|c|c|c|}
\hline & \multirow{2}{*}{ Median earner } & \multicolumn{5}{|c|}{ Individual earnings, multiple of mean } \\
\hline & & 0.5 & 0.75 & 1 & 1.5 & 2 \\
\hline Australia & 45.9 & 68.7 & 50.3 & 41.0 & 31.8 & 27.2 \\
\hline Austria & 71.2 & 71.2 & 71.2 & 71.2 & 69.7 & 52.3 \\
\hline Belgium & 37.9 & 50.9 & 38.1 & 37.6 & 29.2 & 21.9 \\
\hline Canada & 49.5 & 75.4 & 54.4 & 43.9 & 29.6 & 22.2 \\
\hline Czech Republic & 49.1 & 71.5 & 53.4 & 44.3 & 32.8 & 26.0 \\
\hline Denmark & 78.2 & 113.9 & 85.0 & 70.6 & 56.2 & 50.0 \\
\hline Finland & 58.2 & 68.7 & 58.2 & 58.2 & 58.2 & 58.2 \\
\hline France & 37.5 & 63.8 & 42.5 & 37.4 & 34.0 & 32.3 \\
\hline Germany & 35.5 & 38.6 & 35.5 & 35.5 & 35.5 & 26.7 \\
\hline Greece & 92.9 & 92.9 & 92.9 & 92.9 & 92.9 & 92.9 \\
\hline Hungary & 66.8 & 66.8 & 66.8 & 66.8 & 66.8 & 66.8 \\
\hline Iceland & 74.8 & 104.6 & 80.4 & 68.4 & 64.6 & 63.1 \\
\hline Ireland & 38.2 & 65.0 & 43.3 & 32.5 & 21.7 & 16.2 \\
\hline Italy & 61.0 & 61.0 & 61.0 & 61.0 & 61.0 & 61.0 \\
\hline Japan & 34.4 & 45.5 & 36.5 & 32.1 & 27.6 & 24.9 \\
\hline Korea & 64.6 & 88.8 & 69.2 & 59.4 & 49.6 & 40.1 \\
\hline Luxembourg & 79.8 & 89.1 & 81.6 & 77.8 & 74.0 & 72.2 \\
\hline Mexico & 31.5 & 52.8 & 35.2 & 30.8 & 29.5 & 28.8 \\
\hline Netherlands & 76.7 & 78.6 & 77.1 & 76.3 & 75.5 & 75.1 \\
\hline New Zealand & 46.8 & 79.5 & 53.0 & 39.7 & 26.5 & 19.9 \\
\hline Norway & 59.0 & 65.6 & 60.2 & 58.2 & 49.1 & 41.5 \\
\hline Poland & 53.3 & 53.3 & 53.3 & 53.3 & 53.3 & 53.3 \\
\hline Portugal & 54.3 & 70.4 & 54.5 & 54.1 & 53.4 & 52.7 \\
\hline Slovak Republic & 48.8 & 48.8 & 48.8 & 48.8 & 48.8 & 48.8 \\
\hline Spain & 81.2 & 81.2 & 81.2 & 81.2 & 81.2 & 67.1 \\
\hline Sweden & 60.5 & 75.9 & 63.5 & 57.2 & 60.5 & 63.1 \\
\hline Switzerland & 58.2 & 57.7 & 58.1 & 55.2 & 38.6 & 28.9 \\
\hline Turkey & 65.9 & 67.2 & 65.9 & 65.9 & 65.9 & 65.9 \\
\hline United Kingdom & 32.6 & 51.9 & 36.2 & 29.1 & 21.2 & 15.9 \\
\hline United States & 43.6 & 55.2 & 45.8 & 41.2 & 36.5 & 32.1 \\
\hline OECD average & 56.3 & 69.2 & 58.4 & 54.1 & 49.2 & 44.9 \\
\hline \multicolumn{7}{|l|}{ Women } \\
\hline Italy & 45.7 & 52.8 & 52.8 & 52.8 & 52.8 & 52.8 \\
\hline Mexico & 31.1 & 52.8 & 35.2 & 29.7 & 28.5 & 27.9 \\
\hline Poland & 38.1 & 46.2 & 44.5 & 44.5 & 44.5 & 44.5 \\
\hline Switzerland & 57.8 & 62.8 & 62.6 & 59.1 & 41.2 & 30.9 \\
\hline \multicolumn{7}{|l|}{$\begin{array}{l}\text { Memorandum: } \\
\text { France }\end{array}$} \\
\hline Career 25-60 & 37.5 & 63.8 & 42.5 & 37.4 & 34.0 & 32.3 \\
\hline Career 25-65 & 51.9 & 63.8 & 51.9 & 51.9 & 47.9 & 45.9 \\
\hline
\end{tabular}




\section{Definition and measurement}

Eight OECD member countries have defined-contribution (DC) plans as part of their mandatory retirementincome provision. Pension entitlements in DC schemes depend crucially on the rate of return earned by the contributions when they are invested. The baseline assumption of the pension modelling is that the real return earned by DC pensions is $3.5 \%$ per year, net of administrative charges.

Here, replacement rates are also calculated assuming lower or higher rates of return, varying between $1 \%$ and $6 \%$ a year in real terms. (These returns are deliberately symmetric around the baseline assumption.)

A real rate of return on investments of $3.5 \%$ a year is a relatively conservative assumption by historical, empirical standards. Between 1984 and 1996, real rates of return on the investments of pension funds in 8 OECD countries averaged $8 \%$ per year (OECD, 1998, Table V.3). Nonetheless, some commentators argue that the risk-adjusted rate of return on defined-contribution pensions cannot exceed the riskless interest rate (for example, Bodie, 1995). This variable, which underlies the actuarial calculations in this report, is assumed to be $2 \%$. Still others point to the very high administrative costs which have affected individual pension entitlements in some countries as a reason why even more conservative rate of return assumptions should be made (see the references in Whitehouse, 2000 and 2001). On the other hand, other analysts argue that there is an "equity premium" that delivers higher returns than the riskless interest rate even allowing for the costs of the risk borne. These issues have generated a substantial literature. (See, inter alia, Blanchard, 1993; Constantinides et al., 1998; Jagannathan and Kocherlakota, 1996; and Mehra and Prescott, 1985.)

The replacement rates shown in the charts cover workers at four different levels of earnings. They include all sources of retirement income, not only those from the defined-contribution plan. The charts below show the replacement rate under different assumptions for the real rate of return (on the horizontal axis).

Of all the eight countries, pension entitlements are most sensitive to the rate of return on investments in Mexico. This is because the other seven countries have substantial public pensions (whose value, of course, does not vary with the rate of return) whereas Mexico only has a relatively small minimum pension. A high rate of return (6\%) would virtually double the value of Mexican pension entitlements relative to the baseline assumption (of $3.5 \%$ ) for workers on median earnings or above. Lowincome workers, however, would be entitled to the minimum pension at all rates of return below 4.5\%.Only above this level would they build up sufficient funds in their individual accounts to see any benefit from higher returns.

In contrast, contribution rates to private DC schemes are the lowest of these eight countries in Norway ( $2 \%$ of earnings) and Sweden $(2.5 \%$ individual and $2 \%$ occupational) and so these schemes provide only a small part of the overall pension package. The total replacement rate therefore varies much less with the rate of return on investments.

Total pensions in Denmark, Poland and the Slovak Republic are more sensitive to returns than in Norway and Sweden because contribution rates are higher: between 9 and 11\%. Increasing the rate of return from $3.5 \%$ to $6 \%$ would increase total pensions by around $50 \%$ in all these cases. Australia, too, has a relatively high contribution rate of $9 \%$. However, the means test in the public scheme means that the gains in DC benefits from a higher return are partly offset by a lower public pension.

The sensitivity of the total pension entitlement to rates of return varies significantly with individual earnings in three countries: Australia, Denmark and Mexico. In all three, this is because of the effect of first-tier, public pensions. Low-income workers are much less affected by rates of return than are average and high earners. In Hungary, Poland and the Slovak Republic, in contrast, workers at the earnings levels shown are all equally affected by differences in rates of return. 


\section{Gross replacement rates by earnings and rate of return on defined-contribution pensions}
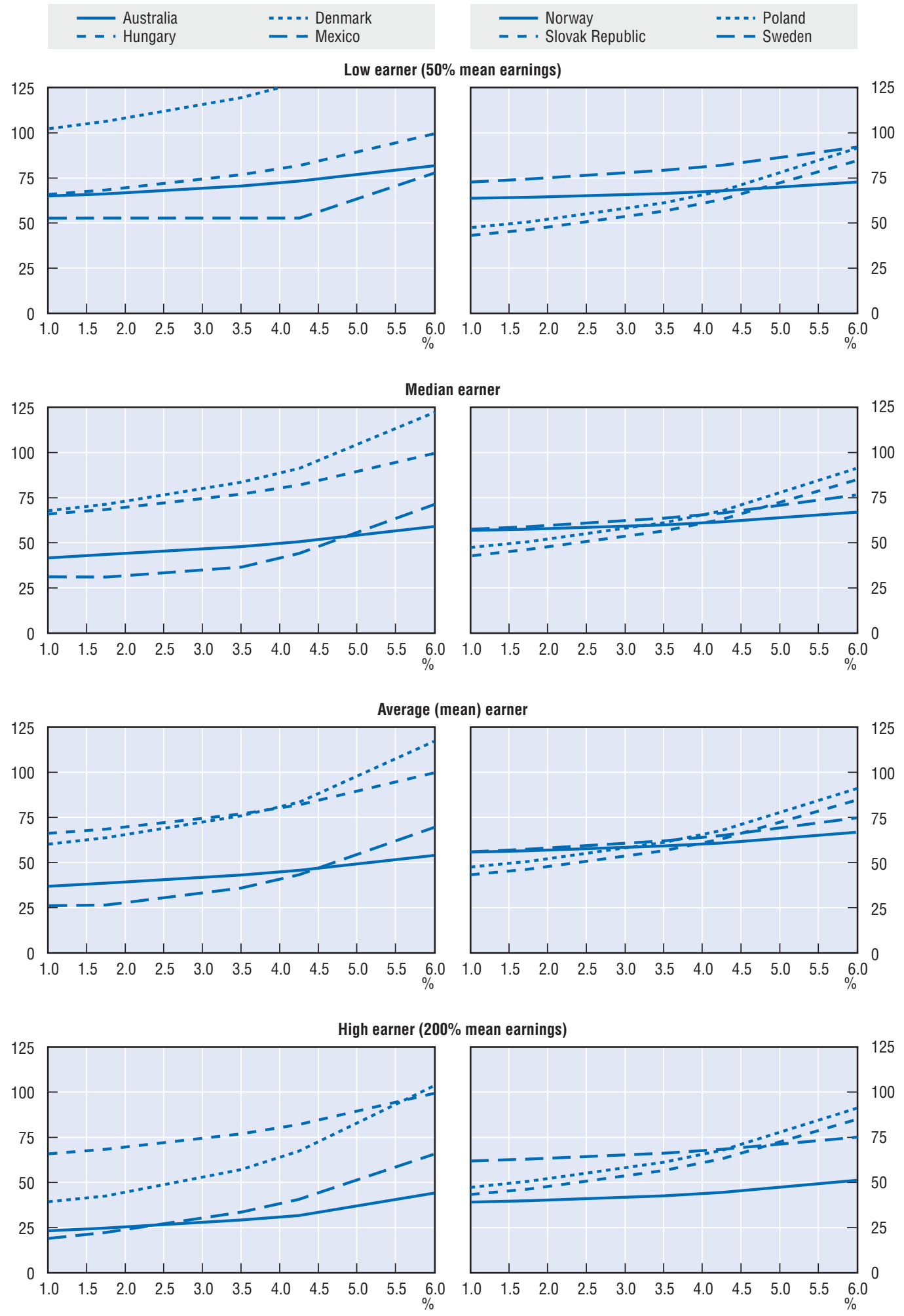

Note: The vertical scale has been capped at $125 \%$ replacement rate. For low earners in Denmark, the replacement rate at the highest investment return is $157 \%$. 


\section{Definition and measurement}

Replacement rates give a first indication of the magnitude of the pension promise, but they are not comprehensive measures, since they measure only the flow of pension benefits at the time of retirement. For a full picture, it is necessary to take account of life expectancy, retirement ages and the indexation of pension benefits, which together determine for how long the pension benefit must be paid and how its value evolves over time. This is captured by pension wealth, a measure of the stock of future flows of pension benefits.

The calculation of pension wealth uses a uniform discount rate of $2 \%$ and country-specific life tables. Since the comparisons refer to prospective pension entitlements, the calculations use mortality projections for the year 2040.

Pension wealth is measured and expressed as a multiple of gross annual individual earnings. It is shown here for workers with earnings of $0.5,1$ and 2 times the average, separately for men and women.

Pension wealth shows the size of the lump sum that would be needed to buy a flow of pension payments equivalent to that promised by the mandatory pension system in each country. Taking Japan as an example, the mandatory pension for a man on average earnings is worth 5.7 times individual earnings at the time of retirement. At half average earnings the mandatory pension is worth 7.9 times individual earnings because replacement rates are higher for low earners.

Luxembourg has the highest pension wealth at every level of earnings. For average earners, it is 19.3 for men and 23.5 for women. This is worth double the average for OECD countries, which amounts to 9.3 for men and 10.9 for women. Pension wealth for average earners is lowest in the United Kingdom, closely followed by Mexico.

Exploring the results on a regional basis, gross pension wealth for average earners is almost identical between the EU-15 countries, the Nordic and the Southern European countries. The regional average ranges between 10.4 and 10.7. In the six Anglophone OECD countries, however, pension wealth of people on mean earnings - at an average of 6.3 times annual pay - is lower by one third than in these other regions.

In countries with shorter life expectancies, such as Hungary, Poland and Turkey, benefits are paid for a shorter retirement period and so, other things equal, the benefit level can be higher. The effect is the reverse in Switzerland and the Nordic countries, where life expectancies are high. Unlike measures of replacement rates, the link between affordability and life expectancy is captured by the pension-wealth indicator.

The chart and the table at the bottom isolate the effect of the different factors that determine pension wealth. The chart on the left-hand side explores the impact of differences in pension age. It shows, separately for men and women, remaining life expectancy from age 55 to age 70 along with the annuity factor, which measures pension wealth. The same annual pension paid to a 60 -year-old is worth $17.5 \%$ more for a man and $16.1 \%$ more for a woman than a benefit drawn at age 65 .

Pension wealth also depends on the indexation of pensions in payment. The table shows that, using the baseline assumption of $2 \%$ real wage growth, indexation to earnings would result in pension wealth over $20 \%$ higher than under price indexation (which is the most common procedure in OECD countries). Mixed indexation - partly to wages, partly to prices is becoming more common (see "Key features of pension-system design", above). The table shows how much higher pension wealth is with these policies than with price indexation. The effect of more generous indexation procedures is larger for women than for men. This is because of women's longer life expectancy, of over $3 \frac{1}{2}$ years on average in OECD countries, resulting in a longer expected retirement over which to benefit from real benefit increases.

Finally, pension wealth also depends on life expectancy. Mortality rates are expected to fall over the coming decades, and so pension wealth measured using today's data would be $14.5 \%$ lower for men and $12.1 \%$ lower for women than the baseline, which is projected mortality rates for 2040 . Cross-country differences are also important. Pension wealth, other things equal would be $12.3 \%$ higher for men and 8.3\% higher for women in Japan than the average country, because of longer life expectancy. In the opposite direction, pension wealth would be $14 \%$ lower in Turkey than the average across OECD countries. 
Gross pension wealth by sex and earnings

Multiple of individual annual gross earnings

\begin{tabular}{|c|c|c|c|c|c|c|}
\hline & \multicolumn{3}{|c|}{ Men } & \multicolumn{3}{|c|}{ Women } \\
\hline & 0.5 & 1 & 2 & 0.5 & 1 & 2 \\
\hline Australia & 12.5 & 7.3 & 4.6 & 14.6 & 8.4 & 5.4 \\
\hline Austria & 12.2 & 11.7 & 8.1 & 14.2 & 13.5 & 9.4 \\
\hline Belgium & 8.8 & 6.2 & 3.6 & 10.2 & 7.2 & 4.2 \\
\hline Canada & 11.5 & 6.7 & 3.4 & 13.4 & 7.8 & 4.0 \\
\hline Czech Republic & 13.0 & 8.1 & 4.8 & 15.3 & 9.5 & 5.6 \\
\hline Denmark & 19.5 & 11.9 & 8.7 & 22.3 & 13.6 & 9.9 \\
\hline Finland & 11.2 & 10.0 & 10.0 & 13.2 & 11.8 & 11.8 \\
\hline France & 11.5 & 9.2 & 8.0 & 13.2 & 10.6 & 9.3 \\
\hline Germany & 7.2 & 7.2 & 5.5 & 8.6 & 8.6 & 6.5 \\
\hline Greece & 14.3 & 14.3 & 14.3 & 16.6 & 16.6 & 16.6 \\
\hline Hungary & 12.4 & 12.4 & 12.4 & 15.4 & 15.4 & 15.4 \\
\hline Iceland & 17.7 & 11.8 & 11.0 & 20.0 & 13.3 & 12.3 \\
\hline Ireland & 11.5 & 5.8 & 2.9 & 13.7 & 6.9 & 3.4 \\
\hline Italy & 10.0 & 10.0 & 9.9 & 10.7 & 10.7 & 10.6 \\
\hline Japan & 7.9 & 5.7 & 4.5 & 8.9 & 6.4 & 5.1 \\
\hline Korea & 13.9 & 9.3 & 6.3 & 16.6 & 11.1 & 7.5 \\
\hline Luxembourg & 21.8 & 19.3 & 18 & 26.6 & 23.5 & 22.0 \\
\hline Mexico & 7.0 & 4.8 & 4.5 & 8.5 & 4.8 & 4.5 \\
\hline Netherlands & 14.9 & 15.1 & 15.2 & 17.4 & 17.7 & 17.8 \\
\hline New Zealand & 14.7 & 7.4 & 3.7 & 17.3 & 8.6 & 4.3 \\
\hline Norway & 11.5 & 10.2 & 7.3 & 13.4 & 11.3 & 8.5 \\
\hline Poland & 8.4 & 8.4 & 8.4 & 8.9 & 8.6 & 8.6 \\
\hline Portugal & 10.5 & 7.9 & 7.7 & 12.3 & 9.2 & 9.0 \\
\hline Slovak Republic & 8.8 & 8.8 & 8.8 & 10.7 & 10.7 & 10.7 \\
\hline Spain & 12.2 & 12.2 & 10.1 & 14.3 & 14.3 & 11.8 \\
\hline Sweden & 12.6 & 10.0 & 10.5 & 14.4 & 11.4 & 12.0 \\
\hline Switzerland & 10.7 & 9.8 & 5.1 & 13.1 & 12.0 & 6.3 \\
\hline Turkey & 9.2 & 9.2 & 9.2 & 10.7 & 10.7 & 10.7 \\
\hline United Kingdom & 8.0 & 4.6 & 2.5 & 9.1 & 5.3 & 2.9 \\
\hline United States & 7.9 & 5.9 & 4.6 & 9.2 & 6.8 & 5.3 \\
\hline OECD average & 11.8 & 9.4 & 7.8 & 13.7 & 10.9 & 9.0 \\
\hline
\end{tabular}

Source: OECD pension models.

\section{Annuity factors and life expectancy by sex and age}

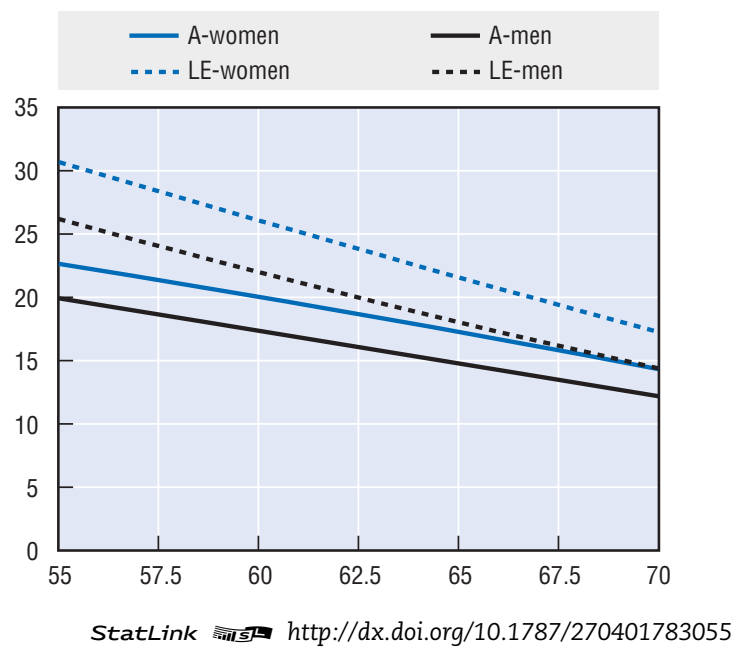

Sensitivity of pension wealth to indexation procedure and life expectancy

\begin{tabular}{lccccc}
\hline Indexation & Prices & Wages & $80 \mathrm{p} / 20 \mathrm{w}$ & $67 \mathrm{p} / 33 \mathrm{w}$ & $50 \mathrm{p} / 50 \mathrm{w}$ \\
\hline Men & 0 & $+21.7 \%$ & $+3.9 \%$ & $+6.5 \%$ & $+10.1 \%$ \\
Women & 0 & $+24.5 \%$ & $+4.3 \%$ & $+7.3 \%$ & $+11.3 \%$ \\
\hline Mortality rates & 2002 & 2020 & 2040 & Japan & Turkey \\
\hline Men & $-14.5 \%$ & $-7.2 \%$ & 0 & $+12.3 \%$ & $-14.4 \%$ \\
Women & $-12.1 \%$ & $-5.1 \%$ & 0 & $+8.3 \%$ & $-14.1 \%$ \\
\hline
\end{tabular}




\section{Definition and measurement}

Net pension wealth is the present value of the flow of pension benefits, taking account of the taxes and social security contributions that retirees have to pay on their pensions. It is measured and expressed as a multiple of gross annual individual earnings in the respective country. The reason for using gross earnings as the comparator is to isolate the effects of taxes and contribution paid in retirement from those paid when working. This definition means that gross and net pension wealth are the same where people are not liable for contributions and income taxes on their pensions.

Net pension wealth is shown for workers with pay of $0.5,1$ and 2 times the average (mean).

Net pension wealth shows the size of the lump sum that would be needed to buy the flow of pension payments, net of personal income taxes and social security contributions, promised by the mandatory pension system in each country. The charts compare gross and net pension wealth for men and women respectively. In countries that lie on the 45 -degree line, gross and net pension wealth are the same because there are no taxes due on pension income.

Beginning with average earners, pension wealth is the same net and gross in eight countries. In the Slovak Republic and Turkey, this is because pensions are not subject to tax. In Australia, Canada, the Czech Republic, Ireland, Mexico and Portugal, this is because mandatory replacement rates are low relative to other OECD countries. Workers on average earnings will not build up sufficient mandatory pension entitlement to be taxed in retirement, due to basic income-tax reliefs and the exemption of pension income from social security contributions. However, high earners in Australia and Portugal will be entitled to some taxable mandatory pension and so net pension wealth is lower than gross for people with double average earnings.

In some cases, countries' rankings of pension wealth changes significantly when measured on a net basis. For example, the Czech Republic has the 12th highest net pension wealth for an average earner compared with the 19th highest measured on a gross basis.

While in eight countries average earners will not be liable for taxes and contributions on their retirement incomes, in others - especially the five Nordic countries, but also Austria - retirees are likely to have a substantial tax burden. In part, this reflects the high level of the gross replacement rate from the mandatory system but also high general levels of taxation in the Nordic countries. Thus, countries that rely heavily on income taxation rank lower in net pension wealth than they do in gross terms. Finland and Sweden, for example, fall from joint 9th in the ranking of gross pension wealth for average earners to positions 18 and 20, respectively, for net pension wealth for men. Measured on a gross basis, pension wealth is $70 \%$ higher in the five Nordic countries than in the six Anglophone countries. However, comparing net pension wealth, the difference is just $30 \%$.

At the top and the bottom of the ranking for average earners, however, there are no changes. Luxembourg again has the highest net pension wealth at every level of earnings. For men, net pension wealth for average earners is lowest in the United Kingdom, followed by Mexico, at less than five times annual individual earnings. However, the position of the two countries is reversed for women, with Mexico having the lowest.

Turning to low earners, the OECD average net pension wealth is lower than gross wealth by 0.9 times annual individual earnings. This reflects the fact that low earners will be liable for income tax on their mandatory pensions in ten OECD countries. In Germany and Greece, such workers would only pay social security contributions on their pension income while, in seven countries, low-income pensioners would pay both taxes and contributions. For average earners, the differential between gross and net pension wealth is slightly higher: 1.3 times annual individual earnings and higher still - 1.6 - for men on double average earnings. The average proportion of pension paid in taxes and contributions is $6.6 \%$ for low earners ( $50 \%$ of mean) compared with $11.6 \%$ for average earners and $16.4 \%$ for high earners ( $200 \%$ of mean). 
Net pension wealth by sex and earnings

Multiple of individual annual gross earnings

\begin{tabular}{|c|c|c|c|c|c|c|}
\hline & \multicolumn{3}{|c|}{ Men } & \multicolumn{3}{|c|}{ Women } \\
\hline & 0.5 & 1 & 2 & 0.5 & 1 & 2 \\
\hline Australia & 12.5 & 7.3 & 4.3 & 14.6 & 8.4 & 5 \\
\hline Austria & 11 & 9 & 5.7 & 12.8 & 10.4 & 6.6 \\
\hline Belgium & 8.8 & 5.6 & 3.1 & 10.2 & 6.5 & 3.6 \\
\hline Canada & 11.5 & 6.6 & 3.3 & 13.4 & 7.7 & 4.0 \\
\hline Czech Republic & 13 & 8.1 & 4.8 & 15.3 & 9.5 & 5.6 \\
\hline Denmark & 13.4 & 8.0 & 5.3 & 15.4 & 9.2 & 6.1 \\
\hline Finland & 9.6 & 7.4 & 6.6 & 11.4 & 8.8 & 7.8 \\
\hline France & 10.8 & 8.1 & 6.6 & 12.4 & 9.3 & 7.6 \\
\hline Germany & 6.2 & 6.3 & 4.2 & 7.9 & 7.0 & 4.9 \\
\hline Greece & 14.3 & 13.0 & 11.1 & 16.5 & 15.1 & 12.8 \\
\hline Hungary & 12.4 & 10.8 & 8.9 & 15.3 & 13.4 & 11.0 \\
\hline Iceland & 14.7 & 9.1 & 7.6 & 16.6 & 10.2 & 8.6 \\
\hline Ireland & 11.5 & 5.8 & 2.9 & 13.7 & 6.9 & 3.4 \\
\hline Italy & 10.0 & 8.4 & 7.4 & 10.7 & 9.4 & 8.2 \\
\hline Japan & 7.2 & 5.3 & 4.0 & 8.2 & 5.9 & 4.5 \\
\hline Korea & 13.7 & 9.1 & 6.0 & 16.3 & 10.8 & 7.1 \\
\hline Luxembourg & 19.6 & 15.6 & 12.7 & 24 & 19.1 & 15.5 \\
\hline Mexico & 7.0 & 4.8 & 4.5 & 8.5 & 4.8 & 4.5 \\
\hline Netherlands & 13.5 & 12.3 & 10.5 & 15.8 & 14.3 & 12.3 \\
\hline New Zealand & 12.2 & 6.1 & 3.0 & 14.3 & 7.1 & 3.6 \\
\hline Norway & 10.1 & 8.3 & 5.6 & 11.8 & 9.7 & 6.6 \\
\hline Poland & 7.2 & 7.0 & 6.9 & 7.9 & 7.3 & 7.1 \\
\hline Portugal & 10.5 & 7.9 & 7.4 & 12.3 & 9.2 & 8.7 \\
\hline Slovak Republic & 8.8 & 8.8 & 8.8 & 10.7 & 10.7 & 10.7 \\
\hline Spain & 11.0 & 10.1 & 7.9 & 12.9 & 11.9 & 9.3 \\
\hline Sweden & 9.5 & 7.2 & 6.8 & 10.9 & 8.2 & 7.8 \\
\hline Switzerland & 10.1 & 8.1 & 4.2 & 12.4 & 9.9 & 5.2 \\
\hline Turkey & 9.2 & 9.2 & 9.2 & 10.7 & 10.7 & 10.7 \\
\hline United Kingdom & 7.9 & 4.5 & 2.5 & 9.1 & 5.2 & 2.8 \\
\hline United States & 7.9 & 5.7 & 4.3 & 9.2 & 6.6 & 5.0 \\
\hline OECD average & 10.9 & 8.1 & 6.2 & 12.7 & 9.4 & 7.2 \\
\hline
\end{tabular}

Source: OECD pension models.

\section{Gross versus net pension wealth by sex, average earner}
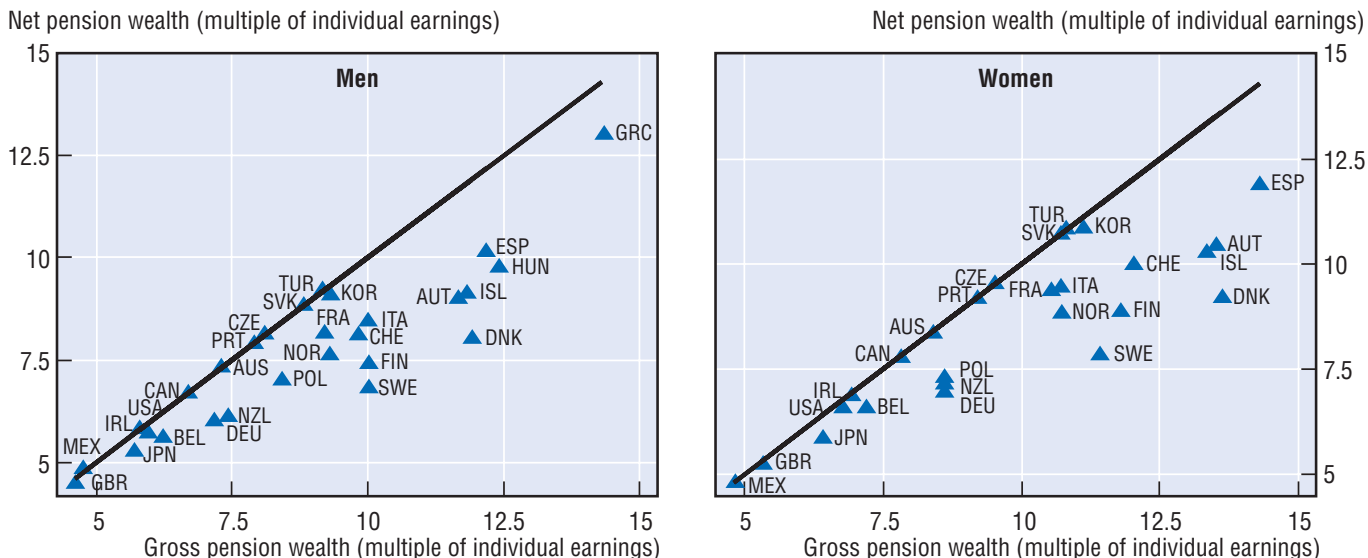

Note: Both scales of both charts have been capped at pension wealth of 15 times individual earnings, which excludes Luxembourg and the Netherlands from both charts and Greece and Hungary from the chart for women.

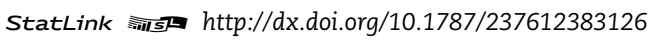




\section{Definition and measurement}

OECD countries' pension systems have very different philosophies, particularly in their relative emphasis on the insurance and redistributive roles. The strength of the link between pre-retirement earnings and postretirement pension entitlements is here measured by a summary indicator, the progressivity index. The index is designed so that a pure basic scheme would score $100 \%$ and a pure insurance scheme, zero. The calculation is based on the Gini coefficient. The higher the Gini coefficient, the more unequal is a distribution. Formally, the index of progressivity is calculated as 100 minus the ratio of the Gini coefficient of pension entitlements divided by the Gini coefficient of earnings (expressed as percentages). In each case, the Gini coefficients are calculated using the earnings distribution as the weight. Calculations were carried out both with national data (where available) and with the OECD average for the earnings distribution.

"Pure" basic pension systems pay the same flatrate amount to all pensioners regardless both of their earnings history and their other sources of income. Such a scheme is sometimes also called a "demogrant" or a "citizen's pension". The relative pension value is independent of earnings and the replacement rate declines with earnings. At the other end of the spectrum of benefit design is a "pure insurance" scheme, which aims to pay the same replacement rate to all workers when they retire. Defined-contribution plans conform to this pure-insurance model if the contribution rate is a constant proportion of earnings for all workers. The same applies to earnings-related schemes that offer the same accrual rate regardless of earnings, years of service or age.

These two benchmarks - pure-insurance and pure-basic schemes - underpin an "index of progressivity" constructed for cross-country comparison of pension benefit formulae. The index is designed so that a pure basic scheme would score $100 \%$ and a pure insurance scheme zero. (This is based on the measure of effective progression devised by Musgrave and Thin, 1948.) The former is maximally progressive; the latter is not progressive since the replacement rate is constant. A high score is not necessarily "better" than a low score or vice versa. Countries with a high score simply have different objectives than countries with a low score.

The first column of the table shows the results for the Gini coefficient of gross pension benefits. The second column shows the index of progressivity of the benefit formula. In pure basic systems - Ireland and New Zealand - the index is, of course, $100 \%$. Other countries with highly progressive pension systems are Australia, Canada, the Czech Republic, and the United Kingdom where the index is above $65 \%$. These countries all have targeted or basic pensions that play a major role in retirement-income provision.

At the other end of the scale, Finland, Hungary, Italy, the Netherlands, Poland, the Slovak Republic and Turkey have almost entirely proportional systems with very limited progressivity. The index is less than $10 \%$ in all these cases. This group includes two of the countries with notional accounts, which were deliberately designed to have a close link between contributions and benefits. Other countries lie between these two groups.

The average index across OECD countries is $36.9 \%$. The regional differences, however, are striking. While the Anglophone countries show an average index of $82.7 \%$, meaning that their systems are strongly progressive, Southern European countries present an average index of only $10.2 \%$, indicating a very strong link between earnings and pension benefits.

To explore the extent to which inequality in pension entitlements is explained by differences in the benefit formula or in inequality of earnings in a particular country, the table presents results based on both the national and the OECD average distribution of earnings. (The charts below show the distribution of earnings for selected countries.) Taking the OECD averages for the 18 countries for which data are complete, the index of progressivity is around $37 \%$ using both the OECD average earnings distribution and country-specific information. There are only significant differences in countries where the national earnings distribution is very different from the OECD average. For example, the Gini coefficient on earnings in the United States is $32.7 \%$ compared with the OECD average of $26.9 \%$ so the progressivity index is 10 percentage points higher measured using national data. Belgium has the most equal distribution of earnings of the 18 countries for which the OECD has data. Its pension system is therefore less equalising when measured using national data.

Finally, it is important to note that the index of progressivity of pension benefit formulae measures only the mandatory parts of the pension systems. Some countries have extensive private occupational and personal pension provision. Taking these into account would make the distribution of pensioners' incomes wider. 


\section{Gini coefficients on pension entitlements and earnings}

OECD average and national earnings-distribution data

\begin{tabular}{|c|c|c|c|c|c|}
\hline & \multicolumn{2}{|c|}{ OECD average distribution } & \multicolumn{3}{|c|}{ National earnings distribution } \\
\hline & Pension Gini & Progressivity index & Pension Gini & Progressivity index & Gini wage \\
\hline Australia & 7.3 & 73.1 & 7.4 & 72.8 & 27.1 \\
\hline Austria & 18.9 & 30.4 & & & \\
\hline Belgium & 11.2 & 58.8 & 9.9 & 54.1 & 20.7 \\
\hline Canada & 3.7 & 86.6 & & & \\
\hline Czech Republic & 8.7 & 68.0 & 8.7 & 66.6 & 25.5 \\
\hline Denmark & 11.1 & 59.3 & & & \\
\hline Finland & 25.1 & 7.6 & 22.4 & 6.7 & 23.6 \\
\hline France & 20.5 & 24.6 & & & \\
\hline Germany & 20.0 & 26.7 & 19.5 & 25.7 & 26.3 \\
\hline Greece & 26.5 & 2.6 & & & \\
\hline Hungary & 26.9 & 1.3 & 33.4 & 0.6 & 33.5 \\
\hline Iceland & 18.0 & 33.9 & & & \\
\hline Ireland & 0.0 & 100.0 & 0.0 & 100.0 & 29.2 \\
\hline Italy & 26.4 & 3.1 & 22.8 & 3.7 & 23.1 \\
\hline Japan & 14.4 & 46.9 & 14.4 & 45.6 & 26.4 \\
\hline Korea & 12.3 & 54.8 & 14.2 & 51.9 & 29.3 \\
\hline Luxembourg & 22.2 & 18.6 & & & \\
\hline Mexico & 19.0 & 30.3 & & & \\
\hline Netherlands & 26.9 & 0.0 & 25.9 & 0.0 & 25.1 \\
\hline New Zealand & 0.0 & 100.0 & & & 27.7 \\
\hline Norway & 17.1 & 37.4 & 13.9 & 36.9 & 21.2 \\
\hline Poland & 25.4 & 6.5 & 28.8 & 5.6 & 30.2 \\
\hline Portugal & 22.1 & 18.8 & & & \\
\hline Slovak Republic & 26.5 & 2.7 & & & \\
\hline Spain & 22.1 & 18.8 & 25.8 & 16.9 & 30.8 \\
\hline Sweden & 23.7 & 12.9 & 20.7 & 10.2 & 22.7 \\
\hline Switzerland & 12.7 & 53.3 & & & \\
\hline Turkey & 25.1 & 7.8 & & & \\
\hline United Kingdom & 5.1 & 81.1 & 5.1 & 82.3 & 28.9 \\
\hline United States & 16.1 & 40.9 & 16.1 & 51.0 & 32.7 \\
\hline OECD average & 17.2 & 36.9 & & & \\
\hline OECD 18 & 17.0 & 37.5 & 17.0 & 37.1 & 26.9 \\
\hline
\end{tabular}

Note: OECD 18 refers to the 18 countries for which national earnings-distribution data are available.

Source: OECD pension models; OECD earnings-distribution database.

Distribution of earnings: OECD average and selected countries
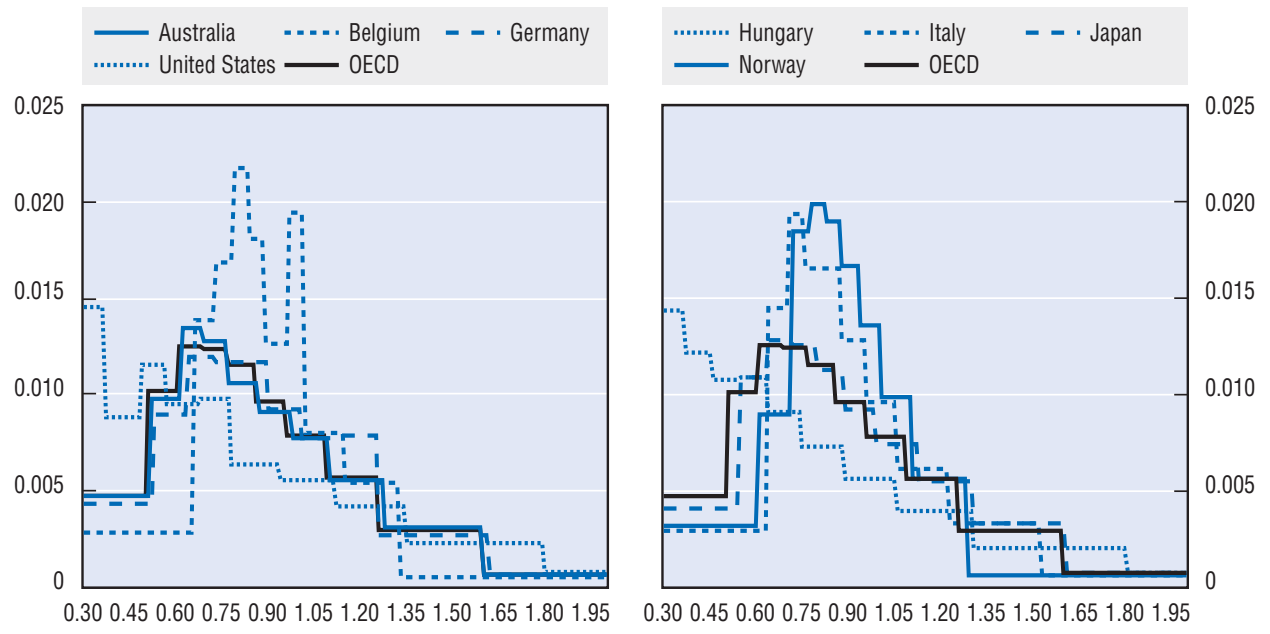

Source: OECD earnings-distribution database. 


\section{Definition and measurement}

The strength of the link between pension entitlements and individual earnings is measured using the relative pension level, that is, the gross individual pension divided by gross economy-wide average earnings (rather than by individual earnings as in the replacement-rate results). It is best seen as an indicator of pension adequacy, since it shows the benefit level that a pensioner will receive in relation to average earnings in the respective country. Individual replacement rates may be quite high, but the pensioner may still receive only a small fraction of economy-wide average earnings. If, for example, a low-income worker - who earned only 50\% of economy-wide average earnings has a replacement rate of $100 \%$, the benefit will only amount to $50 \%$ of economy-wide average earnings. For an average earner, the replacement rate and the relative pension level will be the same.

The relative pension levels are used here to illustrate the link between individual pre-retirement earnings and pension benefits in each country. They are shown for individual earnings from 0.5 to 2 times average (mean) earnings levels.

The chart shows relative pension levels in OECD member countries on the vertical axis and individual pre-retirement earnings on the horizontal. Countries have been grouped by the degree to which pension benefits are related (or not) to individual preretirement earnings. The grouping is based on the value of the Gini coefficient of the distribution of pension levels across the earnings range weighted by the OECD average distribution of earnings. The calculation method and results are set out in the previous section on the progressivity of pension benefit formulae.

In the first set of five countries (Panel A), there is little or no link between pension entitlements and preretirement earnings. In Ireland and New Zealand, pension benefits are purely flat rate. In Canada, the relative pension level varies little: from $37 \%$ for low earners to $44 \%$ for those on average earnings and above. Although Canada has an earnings-related pension scheme, its target replacement rate is very low, its ceiling is set at average economy-wide earnings and a resource-tested benefit is withdrawn against additional income from the earnings-related scheme. In the United Kingdom, the earnings-related scheme has a strongly progressive formula and there is also a basic pension. In Australia, the relatively flat curve results mainly from the means-tested public pension programme. There is also a limit to the earnings for which employers must contribute to the DC scheme.

At the other end of the spectrum lie five countries with a very strong link between pension entitlements and pre-retirement earnings (Panel F). In the Netherlands, there is no ceiling to pensionable earnings in the quasi-mandatory occupational schemes. In the Slovak Republic and Italy, ceilings on pensionable earnings are set at three times or more average economy-wide earnings. For low-paid workers, top-ups from the minimum pensions in are apparent in the charts for all countries except Hungary. But apart from this narrow earnings range, relative pension levels increase with individual earnings in a linear way.

The five countries in Panel E have a slightly weaker link between individual pre-retirement earnings and pensions than those in Panel F. This is due to safety-net benefits for low earners.

The remaining half of OECD countries represents intermediate cases (between those with little or no link between individual earnings and pensions and those with a strong or very strong link). The ten countries in Panels B and C exhibit stronger links between pensions and pre-retirement earnings than the first group of countries, but their pension systems have much more progressive formulae than those of the five countries shown in Panel F. In the Czech Republic, Norway and the United States this redistribution to low earners is primarily the result of a progressive benefit formula that replaces a larger share of pre-retirement income for poorer workers than for average and higher-income earners. In Iceland, this is done through targeted retirementincome programmes. Denmark has significant basic and targeted schemes.

Panel D shows five countries that lie towards the middle of the OECD countries in terms of the link between pension entitlements and pre-retirement earnings. France and Portugal have redistributive pension programmes - minimum and targeted schemes - at lower-income ranges and strong earnings-benefit links at higher income levels. In Germany, there is no minimum pension but poor retirees are eligible for benefits from the general social assistance programme. 
The link between pre-retirement earnings and pension entitlements

Gross pension entitlement as a proportion of economy-wide average earnings

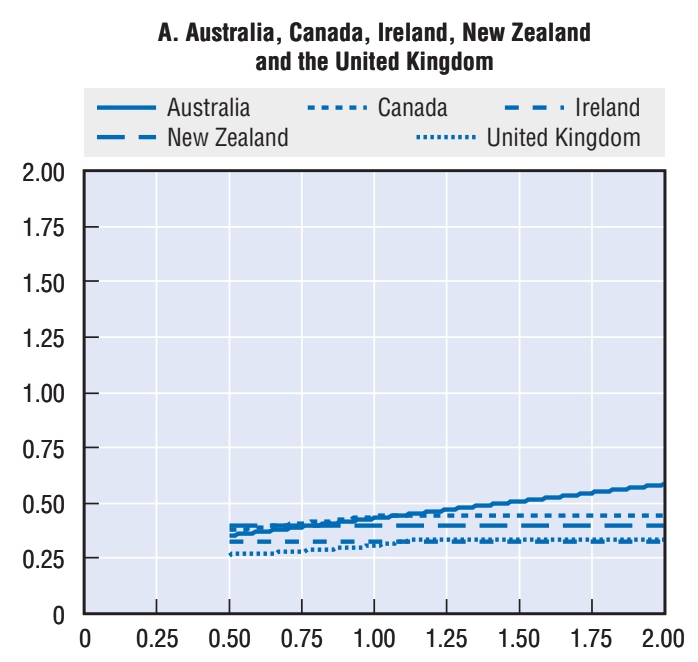

B. Belgium, the Czech Republic, Denmark, Korea and Switzerland

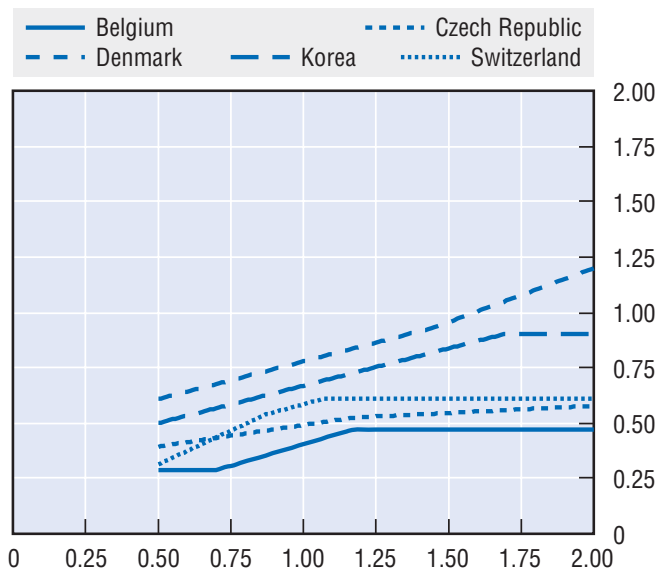

C. Austria, Iceland, Japan, Norway and the United States
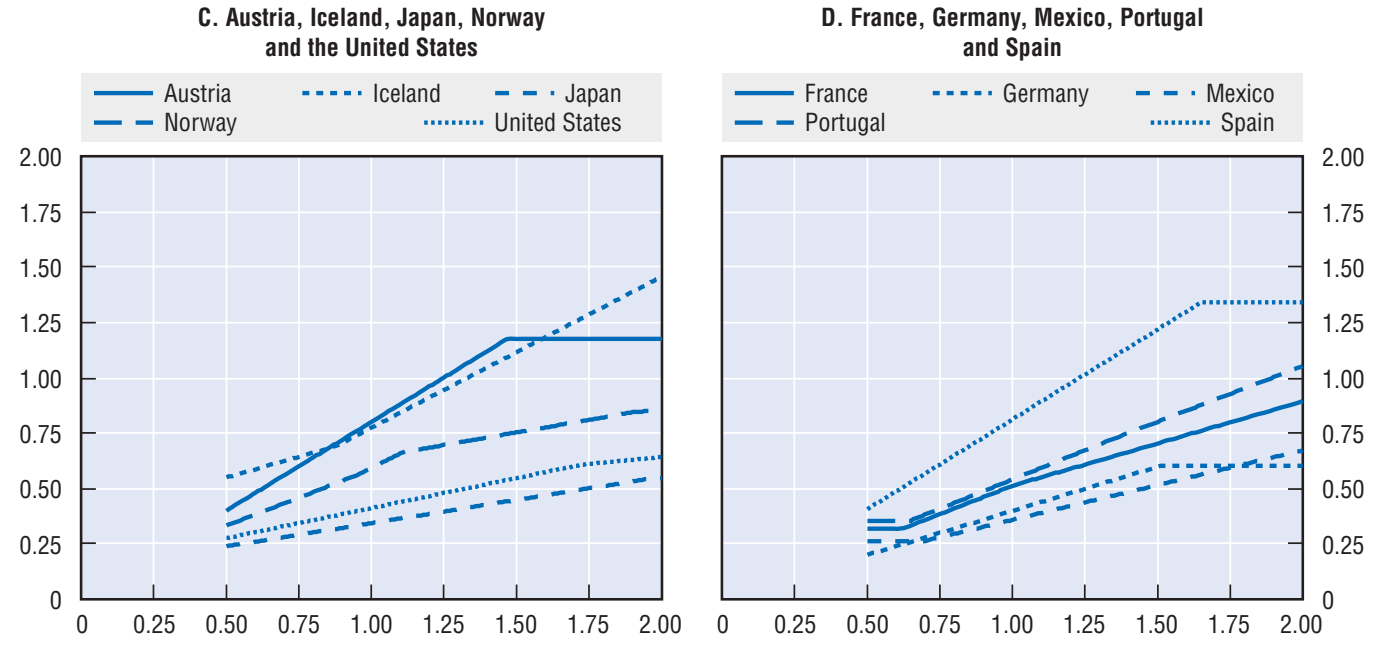

E. Finland, Luxembourg, Poland, Sweden and Turkey

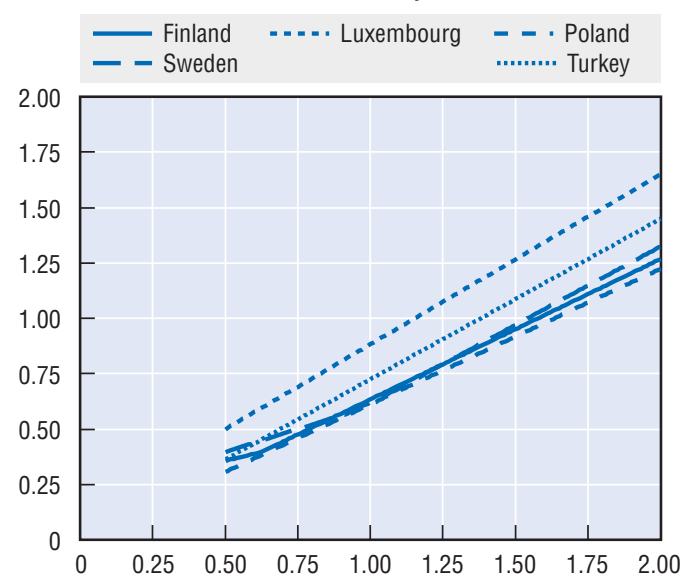

F. Greece, Hungary, Italy, the Netherlands and the Slovak Republic
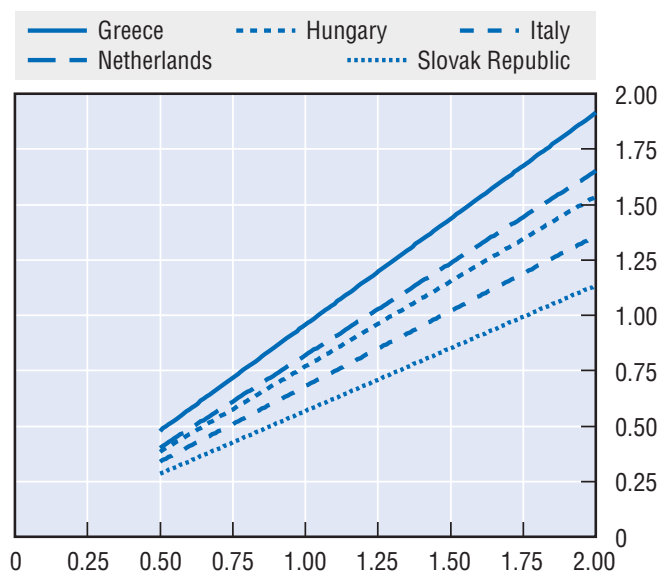

Source: OECD pension models. 


\section{Definition and measurement}

Building on the results for replacement rates and pension levels across the range of individual earnings, it is possible to develop composite indicators of countries' pension systems that aggregate the results for workers at different earnings levels. The indicators are the weighted average pension level and the weighted average pension wealth. The indicators build on the calculations of pension entitlements for people earning between 0.3 and 3 times the economy-wide average (a larger range than shown in the results tables).

Each level of individual earnings is given a weight based on its importance in the distribution of earnings. The calculations use the average distribution of earnings based on data for 18 OECD countries. The earnings distribution is skewed. The mode (or peak) of the distribution is at around two-thirds of mean earnings. The median (the earnings level both below and above which half of employees are situated) is typically between 80 and $85 \%$ of mean earnings. Two-thirds of people earn less than mean earnings. Thus, there are many people with low earnings, and fewer with high earnings, so low earners are given a larger weight in the calculation of the indicator than high earners.

The measure of weighted average pension level combines the earnings distribution with the projections of pension entitlements. The relative pension level is averaged over individuals across the earnings range using the earnings-distribution weights (see the charts in the indicator on "Progressivity of pension benefit formulae"). The result is the weighted average of the pension entitlement expressed as a percentage of economy-wide average earnings.

This indicator is presented in the first column of the table. The average level across the OECD countries is $57.5 \%$. Again, there are vast differences between countries. Seven countries' mandatory systems deliver an average pension of less than $40 \%$ of average earnings. These are Belgium, Germany, Ireland, Japan, Mexico, New Zealand, and the United Kingdom. Greece and Luxembourg are found at the other end of the spectrum. The weighted average pension levels in these countries are $95 \%$ and $87 \%$, respectively. A further five countries have an average pension level above 75\%: Denmark, Hungary, Iceland, the Netherlands and Spain. Next, with pension levels in the low seventies, are Austria and Turkey.

The same weighting can also be applied to the pension wealth measure. The second and third columns of the table show the weighted average of pension wealth, separately for men and women. Given that women's life expectancy is higher than men's, women's pension wealth is relatively higher in all countries. The final column of the table also gives the figures for average pension wealth in US dollars, based on average market exchange rates for 2004.
Luxembourg, not surprisingly, has the highest pension wealth, which averages almost 19 times average earnings for men and 23 times for women. This is worth USD 920000 for men and over USD 1.1 million for women. The averages across OECD countries are 9.2 times average earnings for men and 10.7 for women. The Netherlands and Greece rank second and third. Denmark, Hungary, Iceland and Spain are closely clustered with pension wealth of 11-12 times average earnings.

Average pension wealth is over half a million US dollars in Denmark, the Netherlands and Norway. On this comprehensive measure, the most modest pension systems are those of Belgium, Ireland, Japan, Mexico, the United Kingdom and the United States where pension wealth is less than six times average earnings. This is around two-thirds of the average for OECD countries.

The systems of countries with short life expectancies - such as Poland and Turkey - have more modest values for pension wealth at 8.2 and 9.1, respectively. Despite its relatively high weighted average pension level, Turkey has a lower pension promise given that life expectancy is low compared with other OECD countries. Pension wealth is in turn higher in countries such as France and Hungary because of earlier retirement ages than is the norm for OECD countries. In France, for example, the weighted average pension level is significantly lower than the OECD average while pension wealth is around the average; this is the result of a combination of a low pension age and high life expectancy. 


\section{Weighted average pension level and pension wealth}

Pension level as a percentage of economy-wide average earnings, pension wealth as a multiple of economy-wide average earnings and in US dollars

\begin{tabular}{|c|c|c|c|c|c|}
\hline & \multirow{2}{*}{$\begin{array}{c}\text { Average pension level } \\
\text { Men }\end{array}$} & \multicolumn{2}{|c|}{ Average pension wealth } & \multicolumn{2}{|c|}{ Average pension wealth (USD) } \\
\hline & & Men & Women & Men & Women \\
\hline Australia & 42.9 & 7.2 & 8.4 & 259000 & 302000 \\
\hline Austria & 72.8 & 10.6 & 12.4 & 433000 & 551000 \\
\hline Belgium & 36.7 & 5.6 & 6.5 & 248000 & 318000 \\
\hline Canada & 41.6 & 6.4 & 7.4 & 192000 & 233000 \\
\hline Czech Republic & 46.7 & 7.7 & 9.1 & 63000 & 77000 \\
\hline Denmark & 76.8 & 12.1 & 13.9 & 640000 & 719000 \\
\hline Finland & 64.1 & 10.1 & 12.0 & 396000 & 462000 \\
\hline France & 50.1 & 9.0 & 10.4 & 330000 & 389000 \\
\hline Germany & 36.9 & 6.7 & 8.0 & 342000 & 439000 \\
\hline Greece & 95.1 & 14.2 & 16.6 & 306000 & 358000 \\
\hline Hungary & 76.5 & 12.4 & 15.4 & 104000 & 129000 \\
\hline Iceland & 81.0 & 12.5 & 14.1 & 493000 & 525000 \\
\hline Ireland & 32.5 & 5.8 & 6.9 & 217000 & 259000 \\
\hline Italy & 67.7 & 9.9 & 10.8 & 271000 & 293000 \\
\hline Japan & 33.5 & 5.5 & 6.3 & 251000 & 293000 \\
\hline Korea & 63.8 & 8.9 & 10.7 & 213000 & 265000 \\
\hline Luxembourg & 86.7 & 18.9 & 23.3 & 920000 & 1144000 \\
\hline Mexico & 37.3 & 5.0 & 5.3 & 34000 & 32000 \\
\hline Netherlands & 81.8 & 15.1 & 17.8 & 695000 & 814000 \\
\hline New Zealand & 39.7 & 7.4 & 8.6 & 193000 & 225000 \\
\hline Norway & 54.0 & 9.3 & 11.0 & 505000 & 581000 \\
\hline Poland & 60.1 & 8.2 & 8.6 & 66000 & 69000 \\
\hline Portugal & 55.4 & 8.1 & 9.5 & 131000 & 148000 \\
\hline Slovak Republic & 56.5 & 8.8 & 10.8 & 55000 & 67000 \\
\hline Spain & 75.6 & 11.3 & 13.4 & 278000 & 352000 \\
\hline Sweden & 66.3 & 10.6 & 12.2 & 434000 & 467000 \\
\hline Switzerland & 49.4 & 8.3 & 10.3 & 472000 & 682000 \\
\hline Turkey & 72.0 & 9.1 & 10.8 & 89080 & 105000 \\
\hline United Kingdom & 30.0 & 4.5 & 5.2 & 224000 & 264000 \\
\hline United States & 40.2 & 5.7 & 6.7 & 173000 & 206000 \\
\hline OECD average & 57.5 & 9.2 & 10.7 & 301000 & 359000 \\
\hline
\end{tabular}

Source: OECD pension models; OECD earnings-distribution database.

\section{Weighted averages compared: pension levels versus pension wealth by sex}
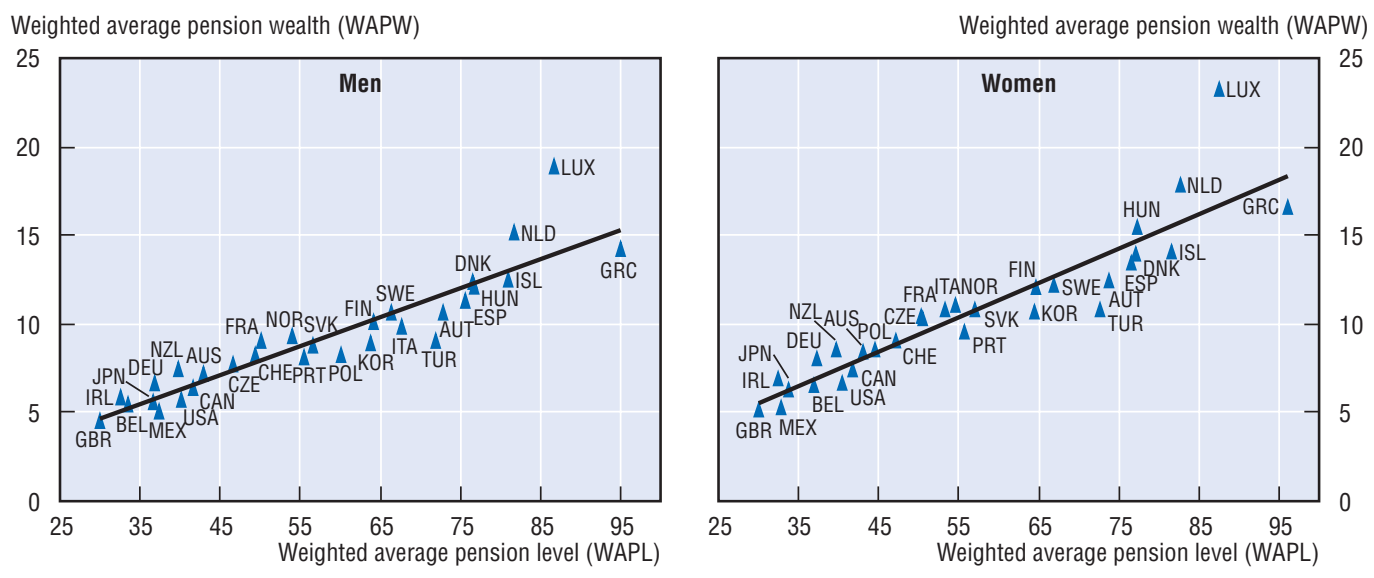

Source: OECD pension models; OECD earnings-distribution database. 


\section{Definition and measurement}

The structure of the pension package is illustrated by using the indicator of weighted average pension wealth presented immediately above. The weights are based on the distribution of earnings. The contribution that each component of the system makes to the potential resource transfer to pensioners from mandatory programmes is calculated as the weighted average pension wealth from each source.

The contribution of each pension system component to the pension promise as a percentage of the total. Since the weighted average pension wealth in some countries does not include all components (e.g. resource-tested programmes often do not enter into this measure as in most countries full-career workers are not eligible for these benefits), the cells for these components remain empty.

Thirteen countries have basic pension schemes, but their importance in terms of the resource transfer to older people varies substantially. In Ireland and New Zealand, there is only a basic pension; thus, its share is $100 \%$. In Korea and in the United Kingdom, the basic pension makes up around one half of the total resource transfer to pensioners. Basic pensions in Japan and in the Netherlands make up around $40 \%$ of the transfer, while in Canada, Denmark and Norway, they contribute about one third to the total pension promise.

Resource-tested programmes also vary hugely in importance. Australia stands out as the only country where this type of benefit makes up almost half of the total pension package. The public pension in Australia is means-tested but the parameters of the means test currently result in well over half of older people receiving some public pension. Resource-tested benefits are also significant in Canada, Denmark and Iceland. For the United Kingdom, resource-tested benefits play a very important role in providing today's older people's incomes. In the long term, however, this will diminish because of the shift to a more progressive formula in the public, earnings-related scheme (as shown by the size of the minimum pension, which derives from minimum credits under this plan). Also, the modelling assumes that the basic pension will increase in future in line with earnings. If the basic pension were price-indexed, then much of its role would be taken up by resource-tested benefits instead.

The two countries with the largest role for minimum pensions - Belgium and the United Kingdom - both have minimum credits. Only in Mexico, Portugal and Sweden are minimum pensions expected to provide a significant part of the overall pension package.

It is important to remember that these results are based on the case of full-career workers. All of the first-tier programmes - basic, resource-tested and minimum pensions - will be much more important for people with incomplete contribution histories. However, it is very difficult to obtain information on the distribution of past contribution histories let alone predict these weights into the future.

The upper chart shows the overall balance between first- and second-tier schemes in the overall retirement-income package. In Ireland and New Zealand, there are no second-tier, mandatory pensions and in the United Kingdom, most of the earnings-related plan goes into providing benefits related to the minimum credit. At the other end of the spectrum, the second tier provides $99 \%$ or more of pensions for full-career workers in ten countries. In some of these - such as Austria, Italy, Poland, Spain and Turkey - this reflects the high replacement rate target of the second tier. In others, such as Switzerland and the United States, the pension benefit formula of the public scheme is progressive, meaning that much of the redistributive work done by the first tier in other countries is carried out by second-tier plans.

Within the second tier, there are definedcontribution (DC) plans in eight countries. These predominate in the resource transfer to older people in Mexico and are half or more of the total in Australia, Poland and the Slovak Republic. All other plans are earnings-related, either defined-benefit (DB), notional accounts or points systems.

The lower chart shows the balance between public and private provision of mandatory pensions for full-career workers, including both first and second tiers. In the 11 countries where the private sector is involved in the mandatory pension system, the private sector on average provides $51 \%$ of the retirement-income package. This ranges from $11 \%$ in Norway to $84 \%$ in Mexico. In other countries, of course, voluntary private pensions play an important role (see the special chapter on private pensions in Part II). 


\section{Structure of the pension package}

Percentage contribution of components of the pension system to weighted average pension wealth

\begin{tabular}{|c|c|c|c|c|c|c|c|}
\hline & \multicolumn{3}{|c|}{ First tier } & \multicolumn{3}{|c|}{ Second tier } & \multirow[b]{2}{*}{ Total } \\
\hline & $\begin{array}{c}\text { Resource } \\
\text {-tested }\end{array}$ & Basic & Minimum & Public & $\begin{array}{c}\text { Private } \\
\text { DB }\end{array}$ & $\begin{array}{c}\text { Private } \\
\text { DC }\end{array}$ & \\
\hline Australia & 45.8 & & & & & 54.2 & 100.0 \\
\hline Austria & & & & 100.0 & & & 100.0 \\
\hline Belgium & & & $5.4^{1}$ & 94.6 & & & 100.0 \\
\hline Canada & 16.5 & 34.5 & & 49.0 & & & 100.0 \\
\hline Czech Republic & & 17.2 & & 82.8 & & & 100.0 \\
\hline Denmark & 12.5 & 31.5 & & & & $56.0^{2}$ & 100.0 \\
\hline Finland & & & 1.5 & 98.5 & & & 100.0 \\
\hline France & 1.3 & & 1.9 & $96.8^{3}$ & & & 100.0 \\
\hline Germany & 1.1 & & & 98.9 & & & 100.0 \\
\hline Greece & & & 0.1 & $99.9^{4}$ & & & 100.0 \\
\hline Hungary & & & & 65.9 & & 34.1 & 100.0 \\
\hline Iceland & 5.7 & 13.3 & & & 81 & & 100.0 \\
\hline Ireland & & 100 & & & & & 100.0 \\
\hline Italy & 0.1 & & & 99.9 & & & 100.0 \\
\hline Japan & & 40.2 & & 59.8 & & & 100.0 \\
\hline Korea & & $51.9^{5}$ & & 48.1 & & & 100.0 \\
\hline Luxembourg & & $13.3^{6}$ & 0.1 & 86.6 & & & 100.0 \\
\hline Mexico & & $11.8^{7}$ & 4.3 & & & 83.9 & 100.0 \\
\hline Netherlands & & 38.2 & & & 61.8 & & 100.0 \\
\hline New Zealand & & 100 & & & & & 100.0 \\
\hline Norway & & 30.1 & 0.4 & 58.5 & & 11.1 & 100.0 \\
\hline Poland & & & 0.3 & 48.8 & & 50.9 & 100.0 \\
\hline Portugal & & & 3.5 & 96.5 & & & 100.0 \\
\hline Slovak Republic & & & 0.2 & 45.3 & & 54.5 & 100.0 \\
\hline Spain & & & 0.2 & 99.8 & & & 100.0 \\
\hline Sweden & & & 4.7 & 49.0 & 26.4 & $19.9^{8}$ & 100.0 \\
\hline Switzerland & 0.1 & & & 68.4 & 31.5 & & 100.0 \\
\hline Turkey & & & 0.8 & 99.2 & & & 100.0 \\
\hline United Kingdom & 0.5 & 50.8 & $33.8^{9}$ & 15.0 & & & 100.0 \\
\hline United States & & & & 100.0 & & & 100.0 \\
\hline OECD & 2.8 & 1.9 & 17.8 & 58.7 & 6.7 & 12.2 & 100.0 \\
\hline
\end{tabular}

1. Belgium: includes both minimum pension and minimum credits.

2. Denmark: private DC plans include both quasi-mandatory occupational (51.0\%) and the special pension (5.0\%).

3. France: public pensions include both the state scheme (59.3\%) and the complementary, occupational scheme (37.5\%).

4. Greece: public pension is made up of the main $(73.0 \%)$ and the supplementary components (26.9\%).

5. Korea: basic component represents the part of the public pension based on average rather than individual earnings.

6. Luxembourg: basic pension also includes the end-of-the-year allowance.

7. Mexico: basic component calculated from the flat-rate government contribution to DC accounts of $5.5 \%$ the real minimum wage from 1997.

8. Sweden: private DC includes both the mandatory premium pension (11.2\%) and the occupational DC scheme (8.7\%).

9. United Kingdom: minimum pension relates to minimum credits in public, earnings-related scheme.

Source: OECD pension models.

\section{Balance between first-tier, redistributive programmes and second-tier, insurance schemes}

Percentage of weighted average pension wealth

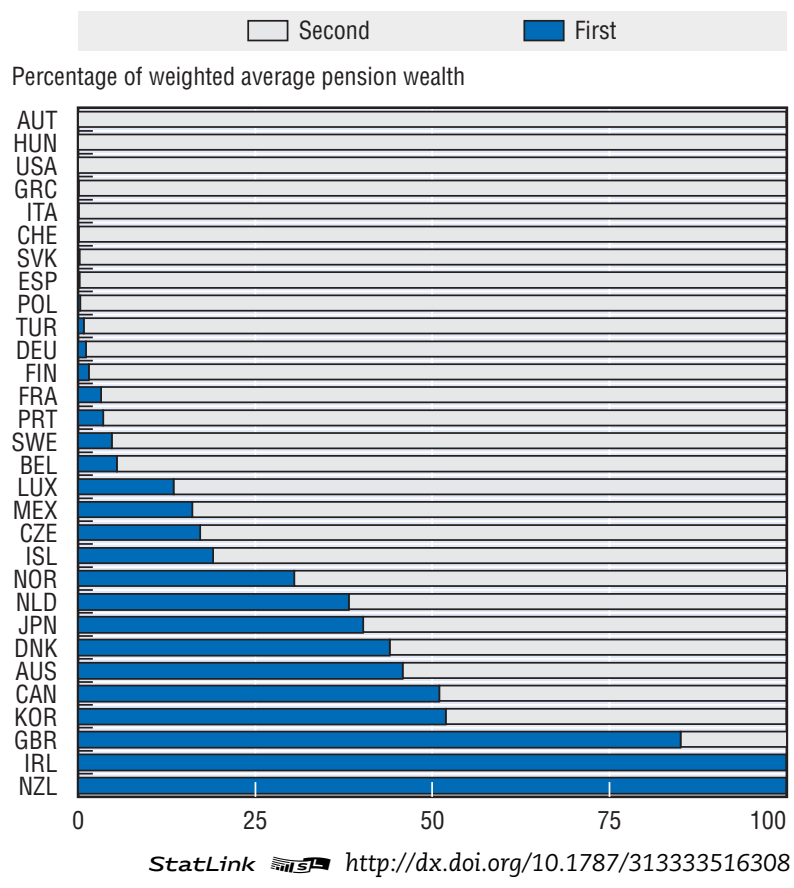

\section{Balance between public and private provision of mandatory pensions}

Percentage of weighted average pension wealth

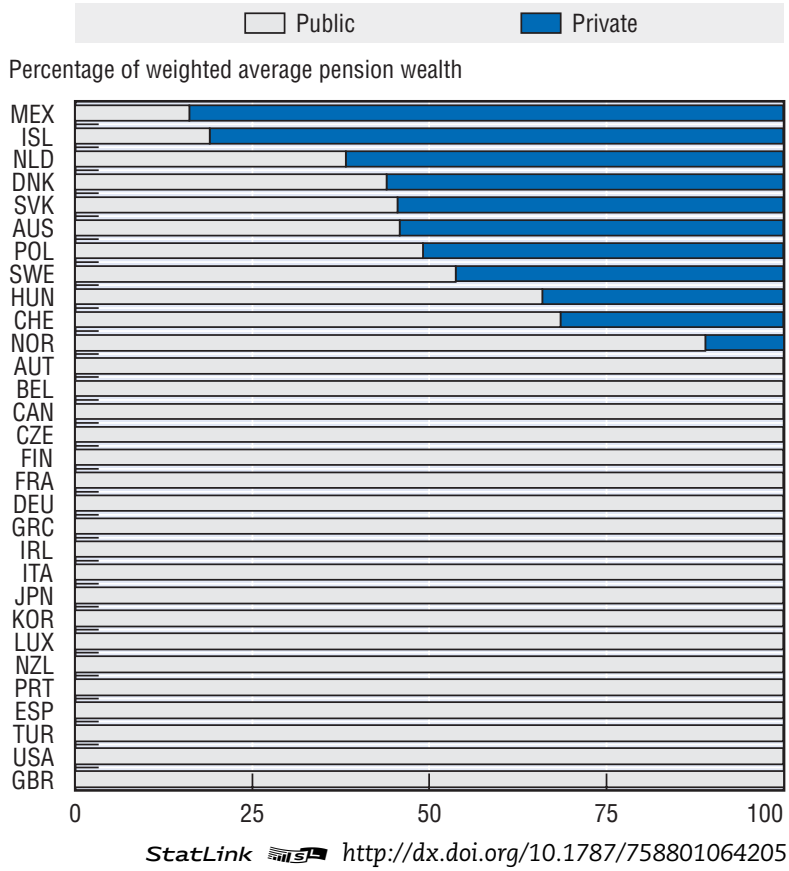




\section{References}

Blanchard, O.J. (1993), “The Vanishing Equity Premium”, in R. O’Brien (ed.), Finance and the International Economy, Vol. 7, Oxford University Press.

Bodie, Z. (1995), “On the Risk of Stocks in the Long Run”, Financial Analysts' Journal, May-June, pp. 18-22.

Constantinides, G., J. Donaldson and R. Mehra (1998), “Junior Can't Borrow: A New Perspective on the Equity Premium Puzzle”, Working Paper No. 6617, National Bureau of Economic Research, Cambridge.

Jagannathan, R. and N. Kocherlakota (1996), "Why Should Older People Invest Less in Stocks than Younger People?”, Federal Reserve Bank of Minneapolis Quarterly Review, Vol. 20, No. 3, Summer.

Mehra, R. and E.C. Prescott (1985), “The Equity Premium: A Puzzle”, Journal of Monetary Economics, Vol. 15, pp. 145-161.

Musgrave, R.A and T. Thin (1948), “Income Tax Progression 1924-48”, Journal of Political Economy, Vol. 56, pp. 498-514, December.

OECD (1998), Maintaining Prosperity in an Ageing Society, Paris.

OECD (2004), OECD Classification and Glossary of Private Pensions, Paris.

OECD (2005a), Pensions at a Glance: Public Policies across OECD Countries, Paris.

OECD (2005b), Society at a Glance: OECD Social Indicators, Paris.

OECD (2006), Live Longer, Work Longer, Paris.

Whitehouse, E.R. (2000), “Administrative Charges for Funded Pensions: Measurement Concepts, International Comparison and Assessment”, Journal of Applied Social Science Studies, Vol. 120, No. 3, pp. 311-361.

Whitehouse, E.R. (2001), “Administrative Charges for Funded Pensions: Comparison and Assessment of 13 Countries", Private Pension Systems: Administrative Costs and Reforms, Private Pensions Series, Vol. 3, OECD, Paris. 


\section{PART II}

\section{Pension Reforms and Private Pensions}

This part presents two special chapters on pension reforms and private pensions. Both chapters use the OECD pension models to explore more deeply the central issues of pension policy in national debates.

The framework of Pensions at a Glance is forward-looking, focusing on future pension entitlements of today's workers. However, the past decade has seen intense reform activity in the world of pensions and retirement in many OECD countries. The first special chapter looks at what countries did and how this is likely to affect future benefits.

A number of these reforms have increased the role of the private sector in pension provision. The second special chapter identifies the complex range of private retirement arrangements and quantifies the savings effort necessary to maintain standards of living in retirement. 



\section{A Decade of Pension Reforms: The Impact on Future Benefits}

I

In the past decade, around half of OECD countries have either undertaken far-reaching reforms that have changed the structure of their pension systems or adopted a series of smaller reforms which, taken together, often also have had a substantial impact on future pension entitlements.

This special chapter discusses the most important pension reforms that took place in OECD countries since the early 1990s. It starts with an overview of the types of reform measures taken. This is followed by an analysis of the impact of these reforms on pension entitlements. The effect is measured, using the OECD pension models, by comparing standard indicators of pension systems. There have been numerous studies of the effect of pension reform on the public finances, ${ }^{1}$ but only a few have explicitly considered the social impact of changing retirement-income regimes, on equity and the distribution of income, for example. ${ }^{2}$

Four key impacts of pension reforms are explored. The first is the financial impact: how much smaller will future benefits be for workers entering the labour market today compared with earlier generations? The second is the distributional impact of reform: how will different groups be affected by pension reforms? The third looks at the structure of pension systems: how has responsibility for pension provision been rebalanced between public and private sectors? A fourth motive for pension reform has been to raise work incentives, i.e. encourage people to work longer.

\subsection{Overview of pension reforms in OECD countries}

Table II.1.1 summarises the elements of major reforms to retirement income systems since 1990, with five main categories of change identified. Some 17 OECD countries had major reforms that affected the entitlements of the standard, full-career worker over this period. In the other 13 countries, changes were less significant in their impact: for example, changing pension ages only for women or adjusting benefits for early or late retirement alone. The empirical results in Section 1.2 below look at 16 of the 17 countries with substantial changes. The only major reform not analysed is the introduction of mandatory defined-contribution (DC) pensions in Australia. ${ }^{3}$

\section{Increasing pension eligibility age}

Most OECD countries now have a standard retirement age of 65 years for men. In Iceland, Norway and the United States, the pension eligibility age is either already 67 or it is being increased to this age. Denmark, Germany and the United Kingdom are in the process of legislating increases. France is the member country with the lowest pension eligibility age: 60 years. 
Several countries, including Australia, Belgium, Portugal and the United Kingdom, will equalise retirement ages for men with those of women. Following reforms, only Italy, Mexico, Poland and Switzerland currently plan to have different pension ages for women than men in the long term. In the Czech Republic, the retirement age for women depends on the number of children.

Increases in pension age that affect both men and women are being implemented in the Czech Republic, Greece, Hungary, Italy, Japan, Korea and the United States.

Increasing pension eligibility ages will improve financial sustainability and retirement incentives. However, there may be a social cost to such reforms if they penalise those who are forced to retire early through no fault of their own.

\section{Increasing the reward for continuing in work}

Penalties for early retirement or increases in the number of years of contributions required to receive a full pension have been introduced or increased in many countries, as described in Live Longer, Work Longer (OECD, 2006b). Similarly, others have introduced or increased the increments or bonuses paid to people retiring after the normal pension age. The measures aim to reduce early pension benefits by an amount that corresponds both to the lower amount of contributions paid by the worker and to the increase in the period over which the worker will receive pension payments (see Whitehouse, 2007a; Queisser and Whitehouse, 2006).

In Australia, a new lump-sum bonus was introduced as an incentive for older workers to remain in the labour force for a longer time. In Finland, older workers are given higher accrual rates while in Hungary the previously higher accrual rates for younger workers were reduced to a uniform level for all workers. Austria, France, Germany, Portugal and the United States all changed the benefit reductions and increments for early and late retirement, respectively. In the United Kingdom, the public pension now offers a larger increase for workers who stay in work beyond the standard retirement age.

These measures to improve retirement incentives should increase financial sustainability. By improving equity between workers who retire at different ages, the social and distributional effect can also be positive.

\section{Changes in the way earnings are measured to calculate benefits}

Many earnings-related schemes used to calculate benefits with respect to only a few years of final or best earnings. Seven OECD countries have extended the period over which earnings are measured since 1990. France is moving from the best 10 years to the best 25 years in the public scheme. Austria is gradually extending the averaging period from the 15 to the 40 best years. Finland, Poland, Portugal and Sweden are all moving to a lifetime average earnings measure. The largest change happened in the Slovak Republic where the earnings measure used to be the best five in the final 10 years of earnings; it will now be lifetime average earnings. As a result of these reforms, most OECD countries 17 out of the 22 with the relevant kinds of scheme - now use a lifetime earnings measure or a close proxy for it.

The impact of changes in the earnings measure on pension benefits depends on how much earnings rise over the career of a worker (see below). If earnings stay stable over the whole career, changes in the earnings measure will not affect entitlements. But for workers with steeply rising earnings, the impact can be substantial. 
Extending the period over which earnings are measured will tend to cut pension benefits. The average of the best years or final earnings is usually higher than the average over the lifetime because the latter also takes earlier years with lower earnings into account. Such reform will improve financial sustainability.

The social effects of such changes are more complex. Individuals who are most affected are those whose earnings rise more steeply with age. These people tend to be higher paid workers and, usually, men. Low-skilled workers typically have flatter real age-earnings profiles, as do women (OECD, 2006b, Figure 3.4).

\section{Changing the valorisation of past earnings}

In all earnings-related public pension systems of OECD countries, past earnings are revalued to take account of changes in living standards between the time pension rights accrued and the time they are claimed. This process is here called "valorisation" although it is also known as pre-retirement indexation.

The majority of OECD countries with earnings-related schemes valorise past earnings in line with economy-wide wage growth. However, several OECD countries have moved away from earnings valorisation in recent years. For example, France moved to price valorisation in the public scheme as early as 1985 and in the occupational schemes in 1996. Finland, Poland and Portugal valorise past earnings with a mix of wage and price growth; recent reforms have changed the weights of price and earnings inflation in the valorisation formula used in Finland and Poland.

Valorisation of past earnings has a large effect on the value of pension benefits. A generic example illustrates the impact of changes in valorisation policy: average real wage growth of $2 \%$ and price inflation of $2.5 \%$ is assumed, implying a $4.5 \%$ annual increase in nominal earnings. For a full-career worker, i.e., someone working from age 20 to 65 , valorising past earnings with prices results in a pension benefit on retirement that is $40 \%$ lower than a pension resulting from valorisation in line with economy-wide average earnings. This is due to the "compound-interest" effect: when their past earnings are revalued workers lose out each year of their career compared to the evolution of their wages.

Again, financial sustainability is improved by a move to a less generous valorisation procedure. The social effects are the opposite of those arising from the extension of the period over which earnings are measured to calculate benefits (see above). People with steeper age-earnings profiles will tend to lose less from a shift to prices valorisation than those with relatively constant real earnings. This is because prices valorisation puts a lower weight on earlier years' earnings (which are less important for a worker with a steep age-earnings profile) than does earnings valorisation.

\section{Linking pensions to higher life expectancy}

Systemic reforms that established defined-contribution (DC) schemes or mechanisms that adjust benefits or the pension age to increasing life expectancy have been proposed or implemented in around half of OECD countries (see Whitehouse, 2007b).

DC schemes - whether they are funded or notional - automatically adjust benefits to life expectancy. Pension capital is accumulated in an individual account and needs to be transformed into a regular pension payment, an annuity, at retirement. Annuity benefits will be lower, the higher life expectancy is at the time of retirement because of the longer expected duration of the pension payment. Since the late 1990s, Hungary, Poland, the 


\begin{tabular}{|c|c|c|c|c|c|c|}
\hline & Pension eligibility age & Adjusted retirement incentives & $\begin{array}{l}\text { Change of years in benefit formula } \\
\text { or qualifying conditions }\end{array}$ & $\begin{array}{l}\text { Link to life expectancy } \\
\text { and/or financial sustainability }\end{array}$ & Defined contribution scheme & Other \\
\hline Australia & $\begin{array}{l}\text { Pension age for women rising } \\
\text { from } 60 \text { to } 65 . \\
\text { Increase from } 55 \text { to } 60 \text { in age } \\
\text { to access private pensions. }\end{array}$ & $\begin{array}{l}\text { New lump-sum bonus for } \\
\text { deferring public pension. }\end{array}$ & & $\begin{array}{l}\text { Through annuity calculation } \\
\text { in DC scheme. }\end{array}$ & $\begin{array}{l}\text { Mandatory DC scheme introduced } \\
\text { in addition to public pension. }\end{array}$ & $\begin{array}{l}\text { Lower withdrawal rate for income } \\
\text { test in the public pension. }\end{array}$ \\
\hline Austria & $\begin{array}{l}\text { Early retirement age increased } \\
\text { by } 1.5 \text { years. } \\
\text { Pension corridor between } 62 \\
\text { and } 65 . \\
\text { Pension ages for women aligned } \\
\text { with those of men. }\end{array}$ & $\begin{array}{l}\text { Benefit reduction for early } \\
\text { retirement introduced and set to } \\
\text { increase. Tighter access to early } \\
\text { retirement. }\end{array}$ & Best 15 years to 40 years. & $\begin{array}{l}\text { Introduction of sustainability } \\
\text { factor under discussion. }\end{array}$ & & $\begin{array}{l}\text { Reduction in accrual rate. Less } \\
\text { generous indexation for higher } \\
\text { pensions. }\end{array}$ \\
\hline Belgium & $\begin{array}{l}\text { Pension age for women aligned } \\
\text { with that for men. }\end{array}$ & $\begin{array}{l}\text { Pension bonus for workers above } \\
\text { age } 62 \\
\text { Different accounting for work } \\
\text { and credit periods } \\
\text { Fiscal incentive to take-up private } \\
\text { pensions only at standard pension } \\
\text { age. }\end{array}$ & $\begin{array}{l}\text { Contribution condition for early } \\
\text { retirement at } 60 \text { tightened. }\end{array}$ & & & \\
\hline Canada & & & & & & $\begin{array}{l}\text { Pre-funding of earnings-related } \\
\text { plan. }\end{array}$ \\
\hline Czech Republic & $\begin{array}{l}\text { Phased increase in normal } \\
\text { pension age to } 63 \text {. }\end{array}$ & $\begin{array}{l}\text { Changes in increments and } \\
\text { reductions for early/late } \\
\text { retirement. }\end{array}$ & & & & \\
\hline Denmark & $\begin{array}{l}\text { Phased increase in normal } \\
\text { pension age from } 65 \text { to } 67 .\end{array}$ & & & $\begin{array}{l}\text { Normal pension age linked to life } \\
\text { expectancy. }\end{array}$ & & \\
\hline Finland & & $\begin{array}{l}\text { Increased accrual rate for people } \\
\text { working age } 63-67 \text {. }\end{array}$ & 10 last years to lifetime average. & $\begin{array}{l}\text { Life-expectancy multiplier } \\
\text { (from 2010). }\end{array}$ & & $\begin{array}{l}\text { Basic part of national pension } \\
\text { income-tested. Higher } \\
\text { valorisation of past earnings and } \\
\text { lower indexation of pensions } \\
\text { in payment. }\end{array}$ \\
\hline France & & $\begin{array}{l}\text { Changes in adjustment to benefits } \\
\text { for early/late retirement in public } \\
\text { and occupational pensions. }\end{array}$ & $\begin{array}{l}\text { Minimum contribution period } \\
\text { increased. Earnings measure } \\
\text { in public scheme from } \\
\text { best } 10 \text { to best } 25 \text { years. }\end{array}$ & $\begin{array}{l}\text { Minimum contribution period } \\
\text { to increase further with changes } \\
\text { in life expectancy. }\end{array}$ & & $\begin{array}{l}\text { Targeted minimum income } \\
\text { of } 85 \% \text { of minimum wage. } \\
\text { Valorisation now effectively } \\
\text { to prices in both plans. }\end{array}$ \\
\hline Germany & & $\begin{array}{l}\text { Reduction in benefits for } \\
\text { retirement before } 65 \text {. }\end{array}$ & & $\begin{array}{l}\text { Valorisation and indexation cut } \\
\text { back as system dependency ratio } \\
\text { worsens. }\end{array}$ & $\begin{array}{l}\text { Voluntary DC pensions with tax } \\
\text { privileges. }\end{array}$ & $\begin{array}{l}\text { Phased abolition of favourable tax } \\
\text { treatment of pension income. }\end{array}$ \\
\hline Greece & Pension age rising from 58 to 65. & & & & & \\
\hline
\end{tabular}




\begin{tabular}{|c|c|c|c|c|c|c|}
\hline & Pension eligibility age & Adjusted retirement incentives & $\begin{array}{l}\text { Change of years in benefit formula } \\
\text { or qualifying conditions }\end{array}$ & $\begin{array}{l}\text { Link to life expectancy } \\
\text { and/or financial sustainability }\end{array}$ & Defined contribution scheme & Other \\
\hline Hungary & $\begin{array}{l}\text { Gradual increase in pension } \\
\text { age from } 55 \text { for women and } 60 \\
\text { for men to } 62 \text { for both. }\end{array}$ & $\begin{array}{l}\text { Accrual rates linear rather than } \\
\text { higher for earlier years. }\end{array}$ & $\begin{array}{l}\text { Pension calculation based on gross } \\
\text { rather than net earnings. }\end{array}$ & $\begin{array}{l}\text { Through annuity calculation in DC } \\
\text { scheme. }\end{array}$ & $\begin{array}{l}\text { DC scheme: mandatory for new } \\
\text { entrants, voluntary for existing } \\
\text { workers. }\end{array}$ & $\begin{array}{l}\text { Minimum pension to be } \\
\text { abolished. Less generous } \\
\text { Indexation of pensions in } \\
\text { payment. Pensions subject } \\
\text { to income tax. }\end{array}$ \\
\hline Iceland & No significant changes since 1990 & & & & & \\
\hline Ireland & & & & & $\begin{array}{l}\text { Incentives for voluntary } \\
\text { retirement savings. }\end{array}$ & $\begin{array}{l}\text { Pre-funding of public pensions } \\
\text { Increase in basic pension. }\end{array}$ \\
\hline Italy & $\begin{array}{l}\text { Normal pension age for men } \\
\text { increased from } 60 \text { to } 65 \text { and } \\
\text { for women from } 55 \text { to } 60 \text {. Early } \\
\text { pension age for men with } \\
35 \text { years' coverage increases } \\
\text { from } 60 \text { to } 62 \text {. }\end{array}$ & $\begin{array}{l}\text { Adjustment to early-retirement } \\
\text { benefits through notional annuity } \\
\text { calculation. }\end{array}$ & $\begin{array}{l}\text { Qualification years for long- } \\
\text { service pension increased } \\
\text { from } 37 \text { to } 40 \text { years. }\end{array}$ & $\begin{array}{l}\text { Through notional annuity } \\
\text { calculation. }\end{array}$ & & $\begin{array}{l}\text { From DB to notional accounts. } \\
\text { Less generous indexation } \\
\text { of higher pensions. }\end{array}$ \\
\hline Japan & $\begin{array}{l}\text { Pension age increasing from } 60 \\
\text { to } 65 \text {. }\end{array}$ & & $\begin{array}{l}\text { Pensionable earnings extended } \\
\text { to include bonuses. }\end{array}$ & $\begin{array}{l}\text { Benefits adjusted to reflect } \\
\text { expected change in dependency } \\
\text { ratio. }\end{array}$ & & Accrual rate reduced. \\
\hline Korea & Pension age rising from 60 to 65 . & & & & & \\
\hline Luxembourg & No significant changes since 1990 & & & & & \\
\hline Mexico & & & & & $\begin{array}{l}\text { Mandatory private DC scheme } \\
\text { replaces public, DB plan. }\end{array}$ & \\
\hline Netherlands & & $\begin{array}{l}\text { Planned abolition of early } \\
\text { retirement programme. }\end{array}$ & $\begin{array}{l}\text { Shift from final to average lifetime } \\
\text { salary in many occupational plans. }\end{array}$ & & & \\
\hline New Zealand & $\begin{array}{l}\text { Pension age increased from } 60 \text { to } \\
65 .\end{array}$ & & & & $\begin{array}{l}\text { Voluntary DC pensions with } \\
\text { auto-enrolment and incentives. }\end{array}$ & Pre-funding of public pension. \\
\hline Norway & & & & & $\begin{array}{l}\text { Mandatory employer } \\
\text { DC contributions. }\end{array}$ & Pre-funding of public pensions \\
\hline Poland & $\begin{array}{l}\text { Withdrawal of early retirement for } \\
\text { certain groups of workers. }\end{array}$ & & $\begin{array}{l}\text { From best consecutive } 10 \text { in final } \\
20 \text { years to lifetime average. }\end{array}$ & $\begin{array}{l}\text { Through notional annuity } \\
\text { calculation in public scheme } \\
\text { and annuity calculation in DC. }\end{array}$ & $\begin{array}{l}\text { DC scheme mandatory for new } \\
\text { entrants and workers under } 30 \text {. }\end{array}$ & $\begin{array}{l}\text { Abolition of basic pension. } \\
\text { From DB to notional accounts. }\end{array}$ \\
\hline Portugal & $\begin{array}{l}\text { Pensionable age for women } \\
\text { aligned with that for men at } 65 \text {. }\end{array}$ & $\begin{array}{l}\text { Introduction of increments } \\
\text { for late retirement and reductions } \\
\text { for early retirement. }\end{array}$ & $\begin{array}{l}\text { From best } 10 \text { out of last } 15 \text { years } \\
\text { to lifetime average earnings }\end{array}$ & $\begin{array}{l}\text { Life-expectancy adjustment } \\
\text { to benefits. }\end{array}$ & & $\begin{array}{l}\text { Less generous indexation } \\
\text { of higher pensions. }\end{array}$ \\
\hline Slovak Republic & $\begin{array}{l}\text { Increase in pension ages to } 62 \\
\text { for men and women. }\end{array}$ & & $\begin{array}{l}\text { From best } 5 \text { in final } 10 \text { years to } \\
\text { lifetime average earnings. }\end{array}$ & $\begin{array}{l}\text { Through annuity calculation in DC } \\
\text { scheme. }\end{array}$ & $\begin{array}{l}\text { DC scheme mandatory for new } \\
\text { entrants and voluntary for existing } \\
\text { workers. }\end{array}$ & From DB to points system. \\
\hline Spain & & $\begin{array}{l}\text { Introduction of small increment } \\
\text { for late retirement. }\end{array}$ & & & & \\
\hline
\end{tabular}




\begin{tabular}{|c|c|c|c|c|c|c|}
\hline & Pension eligibility age & Adjusted retirement incentives & $\begin{array}{l}\text { Change of years in benefit formula } \\
\text { or qualifying conditions }\end{array}$ & $\begin{array}{l}\text { Link to life expectancy } \\
\text { and/or financial sustainability }\end{array}$ & Defined contribution scheme & Other \\
\hline Sweden & & & $\begin{array}{l}\text { Best } 15 \text { years to lifetime average } \\
\text { (public, earnings-related scheme). }\end{array}$ & $\begin{array}{l}\text { Through calculation of notional } \\
\text { annuity and annuity in } \\
\text { DC schemes. Additional } \\
\text { sustainability adjustment } \\
\text { in notional accounts. }\end{array}$ & $\begin{array}{l}\text { DC scheme mandatory for nearly } \\
\text { all workers. Occupational plans } \\
\text { switch from DB to DC. }\end{array}$ & $\begin{array}{l}\text { From DB to notional accounts. } \\
\text { Abolition of income-tax } \\
\text { concessions for pensioners. }\end{array}$ \\
\hline Switzerland & $\begin{array}{l}\text { Pension age for women increased } \\
\text { from } 62 \text { to } 64 \text {. }\end{array}$ & & & & & $\begin{array}{l}\text { Reduction in required interest rate } \\
\text { and annuity rate in mandatory } \\
\text { occupational plans. }\end{array}$ \\
\hline Turkey & Pension age to increase to 65 . & & & & & Reduced accrual rate. \\
\hline United Kingdom & $\begin{array}{l}\text { Women's pension age and } \\
\text { eligibility for guarantee credit } \\
\text { rising from } 60 \text { to } 65\end{array}$ & $\begin{array}{l}\text { Increment for deferring pension } \\
\text { claim increased. Lump-sum } \\
\text { option added. }\end{array}$ & & & $\begin{array}{l}\text { Employers required to provide } \\
\text { access to DC ("stakeholder") } \\
\text { pension. }\end{array}$ & $\begin{array}{l}\text { Increase in basic pension. } \\
\text { Extension of means-tested } \\
\text { supplements. Increased } \\
\text { progressivity of earnings-related } \\
\text { pension. }\end{array}$ \\
\hline United States & $\begin{array}{l}\text { Increase in full pension age } \\
\text { from } 65 \text { to } 67 .\end{array}$ & $\begin{array}{l}\text { Changes in adjustment for early/ } \\
\text { late retirement. }\end{array}$ & & & & \\
\hline
\end{tabular}

Source: Whiteford and Whitehouse (2006); national authorities. 
Slovak Republic and Sweden have introduced funded DC plans as a substitute for part of their public DB pension schemes. Australia's DC plan was added in 1992 to the existing means-tested public pension. In Mexico, the old public pension was entirely replaced by DC plans, starting in 1997. Italy, Poland and Sweden, on the other hand, introduced notional accounts schemes. All of these countries thus have systems which at least in one or some components adjust to life expectancy.

Germany will adjust benefits in the points system to reflect the financial sustainability of the pension system. If life-expectancy increases, ceteris paribus, the number of pensioners per contributor increases and the pension benefit falls. However, the impact of longer life expectancy on benefits might be offset if the number of active workers contributing to the pension system were to increase. Austria is also discussing the introduction of a similar financial-sustainability adjustment.

In Finland and Portugal, the value of pensions will be adjusted to changes in life expectancy at retirement. Another method of adjustment is to increase the standard retirement age and/or the number of contribution years necessary to get a full benefit in line with the evolution of life expectancy. Denmark has introduced a direct link between increasing life expectancy and the pension eligibility age. France, in the 2003 pension reform, linked the required number of years of contributions to get a full pension with life expectancy.

Reducing benefits to reflect longer life expectancy will improve financial sustainability but there may be adverse social effects. It is well established that there is a link between life expectancy on the one hand and socio-economic status, income and wealth on the other (see Brown and McDaid, 2002 for a survey of 45 studies). This can imply that increases in pension ages or reductions in benefits due to increases in average life expectancy may disproportionately hit lower earners. Retirement incentives will be improved because people will have to work longer to build up the same benefit.

\section{Introducing defined-contribution plans}

As noted above, a series of OECD countries introduced DC plans as a substitute for part of the public, earnings-related pension scheme. Usually, some or all workers had a choice over whether to stay with the public, earnings-related pension or switch to mixed public/ private DC provision. (See Mattil and Whitehouse, 2007; and Whitehouse et al., 2007 for further discussion of these reforms.)

The shift to DC pensions is the major reform which shifts the balance between public and private sectors in pension provision. The financial effects are complex. There is not a direct transfer from contributors to beneficiaries with DC plans as there is with a pay-as-you-go system. However, there is still a transfer of resources between generations from workers to retirees and so the overall financial effect is uncertain. Retirement incentives are generally improved. The social effects depend on system design, in particular on the interaction with other public retirement benefits.

\section{Changing the indexation of pensions in payment}

Indexation refers to the adjustment of pensions in payment to changes in prices or earnings. In recent years, many OECD countries have moved away from indexation of pension benefits to earnings towards full or partial indexation to prices. This preserves the purchasing power of pensions, but means that pensioners do not share in the general growth in living standards. ${ }^{4}$ 
Some countries - Hungary, Poland and the Slovak Republic - adjust pensions using a mixed index composed of wage growth and price inflation. This type of adjustment has been in use in Finland and Switzerland for some time. Swiss pensions are increased with an equally weighted index of wage and price growth while recent reforms in Finland changed the relative weighting in the index. German pension indexation, which was linked to wage growth net of taxes and social security contributions, will in future also be adjusted to reflect the system dependency ratio, the relationship between contributors and beneficiaries.

In Italy, higher pensions are increased by less than price inflation (75 or 90\%), while small and medium-level pensions are indexed to prices. Similarly, Austria indexes pensions to prices only up to a ceiling; benefits above that level are increased by a fixed amount and Portugal will in future increase smaller pensions by more than larger ones.

Pension uprating policy is a classic example of ad-hoc policy-making. Even if most countries now have a formal link to prices, indexation is still often suspended as an emergency measure to relieve strong financial pressures on the pension system. This happened several times in Germany before the new link was introduced in 2004. Indexation was also temporarily suspended in Belgium and in the United States. In contrast, in the United Kingdom, ad-hoc changes were made in order to boost benefits, despite a formal link of public pensions to price inflation. ${ }^{5}$

Less generous indexation of pensions in payment improves the financial sustainability of pension systems, but it may pose challenges for long-term social and, thus, political sustainability.

\section{Pre-funding public pensions}

As an alternative means of introducing pre-funding of pension liabilities as opposed to relying on pay-as-you-go finance, some countries have established public pension reserves. In addition to the long-standing reserves in Japan, Sweden and Switzerland, new reserves have been introduced in Canada, Ireland, New Zealand and Norway (see Palacios, 2002). Because this paper focuses on benefit entitlements, these initiatives are not examined further.

\section{Pension contributions}

One of the reasons for the recent wave of pension reforms in OECD countries has been a concern over the effect of high taxes on labour on employment. Table II.1.2 shows the evolution of contribution rates for pensions over the period 1994-2004. Perhaps surprisingly, there is little evidence of an increased pension-contribution burden in this period.

Some 21 OECD countries have a separately identifiable public pension contribution. In half of these, the contribution rate remained basically unchanged over the decade at around 20\%. There were relatively large increases in Canada, Italy, Japan and Korea and smaller increases in the Czech Republic and France. There were falls in five countries, including Hungary, Japan and Netherlands.

There are a number of potential explanations for this counter-intuitive finding. First, governments may have responded to rising pension costs by financing them from general revenues rather than earmarked contributions. Secondly, contribution rates may have remained constant while revenues were increased by broadening the contribution base (by 
Table II.1.2. Pension contribution rates (employee plus employer), 1994, 1999 and 2004

\begin{tabular}{|c|c|c|c|}
\hline & 1994 & 1999 & 2004 \\
\hline Australia & \multicolumn{3}{|c|}{ Private contributions only } \\
\hline Austria & 22.8 & 22.8 & 22.8 \\
\hline Belgium & 16.4 & 16.4 & 16.4 \\
\hline Canada & 5.2 & 7.0 & 9.9 \\
\hline Czech Republic & 26.9 & 26.0 & 28.0 \\
\hline Denmark & \multicolumn{3}{|c|}{ Private contributions only } \\
\hline Finland & 18.6 & 21.5 & 21.4 \\
\hline France & 21.5 & 24.0 & 24.0 \\
\hline Germany & 19.2 & 19.7 & 19.5 \\
\hline Greece & 20.0 & 20.0 & 20.0 \\
\hline Hungary & 30.5 & 30.0 & 26.5 \\
\hline Iceland & \multicolumn{3}{|c|}{ Private contributions only } \\
\hline Ireland & \multicolumn{3}{|c|}{ No separate pension contribution } \\
\hline Italy & 28.3 & 32.7 & 32.7 \\
\hline Japan & 16.5 & 17.4 & 13.9 \\
\hline Korea & 6.0 & 9.0 & 9.0 \\
\hline Luxembourg & 16.0 & 16.0 & 16.0 \\
\hline Mexico & \multicolumn{3}{|c|}{ Private contributions only } \\
\hline Netherlands & 33.1 & 37.7 & 28.1 \\
\hline New Zealand & \multicolumn{3}{|c|}{ No contributions } \\
\hline Norway & \multicolumn{3}{|c|}{ No separate pension contribution } \\
\hline Poland & - & 32.5 & 32.5 \\
\hline Portugal & \multicolumn{3}{|c|}{ No separate pension contribution } \\
\hline Slovak Republic & 28.5 & 27.5 & 26.0 \\
\hline Spain & 29.3 & 28.3 & 28.3 \\
\hline Sweden & 19.1 & 15.1 & 18.9 \\
\hline Switzerland & 9.8 & 9.8 & 9.8 \\
\hline Turkey & 20.0 & 20.0 & 20.0 \\
\hline United Kingdom & \multicolumn{3}{|c|}{ No separate pension contribution } \\
\hline United States & 12.4 & 12.4 & 12.4 \\
\hline OECD (21) & 19.9 & 20.3 & 20.0 \\
\hline
\end{tabular}

Note: Rounded to one decimal place.

Source: OECD (1995b, 2001, 2006a).

increasing ceilings, for example). Thirdly, the profile of demographic ageing implies that much of the pressure on pension costs is yet to come. Finally, pension reforms might have succeeded in controlling costs. However, the OECD Social Expenditures database shows that average public spending on old-age and survivors benefits in the OECD countries increased from $6.7 \%$ of GDP in 1990 to $7.7 \%$ in 2003, see Table II.1.3. There were falls in only seven countries, notably in Finland, Luxembourg and New Zealand. There were very large increases in Italy, Japan, Poland, Portugal and the Slovak Republic of between 3.5\% and 7.5\% of GDP. 
Table II.1.3. Public spending on old-age and survivors' pensions, 1990-2003

\begin{tabular}{|c|c|c|c|c|c|}
\hline & 1990 & 1995 & 2000 & 2003 & Change 1990-2003 \\
\hline Australia & 3.7 & 4.2 & 4.5 & 4.1 & 0.4 \\
\hline Austria & 11.9 & 12.8 & 12.8 & 13.2 & 1.3 \\
\hline Belgium & 9.1 & 9.4 & 9.1 & 9.3 & 0.2 \\
\hline Canada & 4.3 & 4.8 & 4.4 & 4.4 & 0.1 \\
\hline Czech Republic & 6.1 & 6.5 & 8.0 & 8.0 & 1.8 \\
\hline Denmark & 7.4 & 8.4 & 7.1 & 7.2 & -0.2 \\
\hline Finland & 8.1 & 6.8 & 5.9 & 6.4 & -1.7 \\
\hline France & 10.9 & 12.2 & 12.0 & 12.3 & 1.4 \\
\hline Germany & 10.2 & 10.9 & 11.2 & 11.7 & 1.5 \\
\hline Greece & 11.1 & 10.8 & 12.2 & 12.4 & 1.3 \\
\hline Hungary & n.a. & n.a. & 8.0 & 8.7 & n.a. \\
\hline Iceland & 3.5 & 3.8 & 3.6 & 4.2 & 0.6 \\
\hline Ireland & 4.2 & 3.7 & 3.4 & 3.7 & -0.5 \\
\hline Italy & 10.2 & 11.4 & 13.7 & 13.9 & 3.6 \\
\hline Japan & 5.0 & 6.3 & 8.0 & 9.3 & 4.3 \\
\hline Korea & 0.8 & 1.3 & 1.5 & 1.4 & 0.6 \\
\hline Luxembourg & 9.6 & 10.3 & 7.8 & 6.5 & -3.1 \\
\hline Mexico & 0.6 & 0.8 & 0.9 & 1.2 & 0.7 \\
\hline Netherlands & 7.0 & 6.1 & 5.6 & 5.8 & -1.2 \\
\hline New Zealand & 7.4 & 5.7 & 5.0 & 4.5 & -2.9 \\
\hline Norway & 7.6 & 7.5 & 6.8 & 7.4 & -0.3 \\
\hline Poland & 5.3 & 9.6 & 10.9 & 12.4 & 7.2 \\
\hline Portugal & 5.4 & 7.9 & 8.7 & 10.5 & 5.1 \\
\hline Slovak Republic & n.a. & 6.6 & 6.6 & 6.5 & 6.5 \\
\hline Spain & 8.1 & 9.2 & 8.8 & 8.4 & 0.3 \\
\hline Sweden & 9.3 & 10.7 & 10.0 & 10.8 & 1.5 \\
\hline Switzerland & 5.8 & 6.9 & 6.9 & 7.2 & 1.3 \\
\hline Turkey & 3.2 & 3.7 & n.a. & n.a. & n.a. \\
\hline United Kingdom & 5.3 & 6.0 & 5.9 & 6.1 & 0.8 \\
\hline United States & 6.1 & 6.3 & 6.0 & 6.3 & 0.2 \\
\hline OECD & 6.7 & 7.3 & 7.4 & 7.7 & 1.0 \\
\hline
\end{tabular}

n.a.: not available.

Source: OECD Social Expenditures database.

\subsection{Impact of pension reforms in selected OECD countries}

Reforms to retirement-income regimes, whether they occurred in one "big bang" or a series of smaller changes, often changed a range of the parameters and rules of national systems. This makes it difficult to compare these reform packages between countries based on institutional information alone. The analysis that follows compares the microeconomic indicators of pension systems - such as the replacement rate, the relative pension level and pension wealth presented in Part I - before and after reforms. These microeconomic measures are designed to complement the macro picture provided by longterm financial projections of pension systems. The analysis focuses on 16 OECD countries (Austria, Finland, France, Germany, Hungary, Italy, Japan, Korea, Mexico, New Zealand, Poland, Portugal, Slovak Republic, Sweden, Turkey and the United Kingdom) where there have been substantial pension reforms in the past decade.

\section{Methodology}

The results described as "post-reform" are those to be found in the rest of this report. To summarise briefly, these take the situation of a worker entering the labour market 
in 2004 and spending the whole of his or her career under the same set of pension parameters and rules: those applying in 2004 along with any legislated changes that will take effect over time.

The pre-reform scenario is built on the following question: what would the parameters and rules of the pension system have been in 2004 had the pension reform not taken place? This stylised approach is designed to isolate the effects of the reform programme from other changes of the past decade. Thus, mortality rates and economic variables are the same in the two scenarios and the same modelling methodology is used (see the section on "Structure of the report and methodology", p. 11).

The aim is not to calculate pensions for people retiring in 2004. First, the frequency of pension reforms in some countries would mean that many more than two sets of pension rules would need to be modelled along with often complex transition provisions, making the calculations intractable. Secondly, the position of current retirees is better assessed using income-distribution or administrative data on actual benefits of retirees than by microsimulation.

This approach means that two sets of prospective replacement rates are compared: one set that shows the pension entitlements that workers entering the labour market in 2004 were promised if the pre-reform system was still in place. And a second set that shows what entitlements will be under the system that actually existed, i.e., the postreform system, for workers entering the labour market in 2004. This is a microeconomic comparison and so is silent on the affordability of pension promises in the two scenarios.

Changes in the indexation of pensions in payment are captured in the pension-reform modelling through the calculation of pension wealth. However, changes in policy over indexation of pension-system parameters is more difficult to model realistically. As noted in the section on methodology, some countries, such as Sweden and the United Kingdom, in theory propose to index key parameters, such as the value of retirement safety nets, to prices. As previously noted, if implemented over a 40- to 50-year period, this would result in unrealistically low living standards for poorer pensioners which would not be politically sustainable. Therefore, pension-systems parameters are assumed to increase over time in line with average earnings. Note that this assumption is applied consistently to both preand post-reform scenarios regardless of whether there has been any change in parameterindexation policy.

\section{Replacement rates for average earners}

Pension reforms since the 1990s had a strong impact on replacement rates for workers on average earnings. Table II.1.4 shows gross replacement rates before and after the reforms for men and, where they are different, for women. Replacement rates for workers on average earnings are being cut by reforms in all countries except in Hungary where they increase sharply by almost 20 percentage points. The Hungarian result, however, is strongly influenced by the tax system since Hungarian pensions used to be calculated on the basis of earnings net of income taxes. Thus, not all of the increase in replacement rates in Hungary is due to pension reform; tax changes also have a powerful impact. In the United Kingdom, replacement rates are the same before and after reform. The same is true for New Zealand, where the reform merely increased the pension age from 60 to 65 . This change does not show up in the replacement rate since the benefit is flat rate. In Poland and for women in Austria, replacement rates are expected to be similar before and after the reforms. The largest reduction is in Mexico where replacement rates were cut by more than 
half for men and women. However, it should be noted that the post-reform system applies to workers who entered the labour force after 1997. All existing workers were guaranteed to receive at least the benefit that they would have been entitled to under the pre-reform system. There are also large changes in Italy and Portugal, followed by Sweden, France and Austria. Of course, many of these benefit cuts were necessary since the systems had already encountered financial difficulties which were projected to worsen in the future. The pre-reform systems were often "promising" levels of payment which could never actually have been paid.

Table II.1.4. Pre- and post-reform gross replacement rates for workers on average earnings in selected OECD countries ${ }^{1}$

Percentage of individual earnings

\begin{tabular}{|c|c|c|c|c|}
\hline & \multicolumn{2}{|c|}{ Men } & \multicolumn{2}{|c|}{ Women (where different) } \\
\hline & Pre-reform & Post-reform & Pre-reform & Post-reform \\
\hline Austria & 90.0 & 80.1 & 80.0 & 80.1 \\
\hline Finland & 66.3 & 63.4 & & \\
\hline France & 64.7 & 51.2 & & \\
\hline Germany & 48.7 & 39.9 & & \\
\hline Hungary & 57.7 & 76.9 & 52.7 & 76.9 \\
\hline Italy & 90.0 & 67.9 & 80.0 & 52.8 \\
\hline Japan & 40.7 & 34.4 & & \\
\hline Korea & 69.3 & 66.8 & & \\
\hline Mexico & 72.5 & 35.8 & 72.5 & 29.7 \\
\hline New Zealand & 39.7 & 39.7 & & \\
\hline Poland & 62.2 & 61.2 & 57.3 & 44.5 \\
\hline Portugal & 90.1 & 54.1 & & \\
\hline Slovak Republic & 59.5 & 56.7 & & \\
\hline Sweden & 78.9 & 62.1 & & \\
\hline Turkey & 107.6 & 72.5 & 102.8 & 72.5 \\
\hline United Kingdom & 30.8 & 30.8 & & \\
\hline
\end{tabular}

1. OECD countries that have implemented significant pension reforms over the past decade. Source: OECD pension models.

\section{Adequacy of benefits for low-income workers}

Table II.1.5 shows relative pension levels (the pension benefit as a share of economywide average earnings) net of taxes and social security contributions for workers earning half average earnings before and after the reforms. This is a more useful measure to assess benefit adequacy than the replacement rate, since it shows how far away the lowest-income pensioners are from the average standards of living of workers. It is thus a good indicator of poverty risk for retirees.

The results show that only in two out of the 16 countries did the income position of workers earning half the average improve due to reform. In the United Kingdom, the benefit for the lowest-income group rose from $29 \%$ to $36 \%$ of average earnings. The increase can be explained by the introduction of the Second State Pension which has differential replacement rates over different bands of earnings. This mechanism increases entitlements for people with low earnings. In addition, the previous minimum income guarantee was increased from $18 \%$ of average earnings in 1997 to $21 \%$ in 2004; it was subsequently replaced by the pension credit at broadly the same level. In Hungary, the improvement is more marked for female low-income workers. The increase comes 
Table II.1.5. Net relative pension levels pre- and post-reform for low-income workers in selected OECD countries ${ }^{1}$

\begin{tabular}{lcc|cc}
\hline & \multicolumn{2}{c|}{ Men } & \multicolumn{2}{c}{ Women (where different) } \\
\cline { 2 - 5 } & Pre-reform & Post-reform & Pre-reform & 53.2 \\
\hline Austria & 57.8 & 53.2 & 53.1 & \\
Finland & 44.6 & 44.8 & & \\
France & 42.8 & 42.1 & 42.9 & 58.4 \\
Germany & 39.7 & 32.6 & 56.3 \\
Hungary & 52.5 & 58.4 & 51.1 & \\
Italy & 55.9 & 46.7 & \\
Japan & 32.2 & 26.9 & 38.7 \\
Korea & 54.3 & 54.2 & 47.1 & 29.9 \\
Mexico & 38.7 & 28.2 & \\
New Zealand & 41.7 & 41.7 & & \\
Poland & 50.0 & 38.8 & & \\
Portugal & 58.5 & 45.0 & & \\
Slovak Republic & 41.8 & 36.5 & 73.2 & \\
Sweden & 44.7 & 42.8 & & \\
Turkey & 77.2 & 52.0 & & \\
United Kingdom & 29.4 & 36.0 & & \\
\hline
\end{tabular}

1. OECD countries that have implemented significant pension reforms over the past decade. The net relative pension level is individual pension entitlement (net of any taxes and contributions) divided by average earnings, again net of taxes and contributions.

Source: OECD pension models.

predominantly from the change in pension age, which was increased from 55 years for women to 62 years. Entitlements are thus earned for more years both under the DB and the DC components of the new pension system.

In Finland, France and Korea, the income position of low-income pensioners was protected; pre- and post-reform relative pension levels are almost identical. The same is true for female Austrian low-income pensioners. In the Finnish pension reform of 1996, the basic element of the pension system that was partially pension-income tested was replaced with a more targeted national pension that is fully withdrawn against other pension income; in this way, poor pensioners who have insufficient entitlements from the earnings-related pension scheme are guaranteed a minimum pension level. In France, the result is due to a provision in the 2003 pension reform which stipulates that no full-career worker should have a pension benefit below $85 \%$ of the net minimum wage. Although this measure constituted a substantial increase for low-income pensioners, it only just about compensates for the cuts that were made to benefits through the lengthening of the period for the earnings base and the changes made to the occupational schemes in the 1990s.

All other countries saw a decline in benefits as a result of the reforms, even for the poorest group of pensioners. Particularly large reductions of relative pension levels, amounting to 10 or more percentage points, can be observed again in Mexico (from 39\% to $28 \%$ ), in Poland ( $50 \%$ to $39 \%$ ) and in Portugal (from 58\% to 45\%). In Germany, the benefit fell from $40 \%$ to $33 \%$.

In Mexico, the decline is due to the switch from the old DB system to a DC system. Even though all workers receive a government subsidy to their individual accounts and there is a minimum pension, this is not sufficient to maintain the relative pension level of low-income workers who will retire under the new rules. 
In Poland, the reform did not change the level of the minimum pension. But full-career workers on half average earnings are not entitled to this benefit. However, Poland abolished the flat component of its old pension system, which hits low-income workers hardest. Thus, the decline in benefits for workers on half average earnings can be attributed entirely to the systemic reform from the old redistributive system to the new mixed system consisting of notional accounts and funded DC schemes.

In Portugal, the recently agreed pension reform introduces an adjustment of future pensions to increases in life expectancy at age 65. Based on the UN/World Bank database on mortality rates, life expectancy in Portugal at age 65 in the year 2006 is 16.2 years. This is projected to increase to 20.3 years life expectancy in 2050. Thus, benefits are expected to be $81 \%$ of their value under current rules as a result of the link to life expectancy for an individual spending a whole career with this adjustment. Due to the minimum pension, however, the benefit falls less for low-income workers than for workers on average earnings.

In Germany, the decline of benefit is due to the change in calculating the pension-point value (as explained above) and the gradual transition to EET taxation which implies an increase in net wages and a reduction of net pension benefits; since there is no explicit minimum pension in the German system, lower-income groups are not protected from the decline. The only safety-net benefit available is social assistance, which, however, is available to older persons under less strict conditions than for the working-age population. In particular, for the elderly no recourse is taken to income or assets of other family members. But for a worker at half average earnings the pension is above the social assistance level.

\section{The effect of changes in the earnings measure}

The pension modelling assumes that individual earnings grow in line with the economy-wide average (of $2 \%$ real per year). Replacement rates are measured relative to individual earnings, revalued in line with economy-wide average earnings growth to the time of retirement and averaged across the career. With individual earnings tracking the economy-wide average, revalued average earnings are the same as final salary. ${ }^{6}$

A number of countries have changed the way that earnings are measured to calculate pension benefits, typically extending the period over which earnings are measured. In some cases, the effect of these reforms is captured by the pension models under the baseline assumptions. For example, the extension of the averaging period from 10 to 25 years in the French public pension scheme is calculated to cut benefits by $13.2 \%$ for a worker whose earnings track the economy-wide average (because of prices valorisation of earlier years' earnings). In Portugal, the new earnings measure will be lifetime average earnings valorised by a mixed index: $25 \%$ wage growth and $75 \%$ price inflation. On the baseline assumptions, this is expected to cut benefits by $27 \%$ compared with the current earnings measure (final 15 years' salary). Of course, changes in earnings measures were part of a broader reform package; these calculations do not relate to the aggregate effect.

In Poland, the Slovak Republic and Sweden, however, changes in the earnings measure are not reflected in the baseline results. These three countries have all extended the averaging period to the full career from much shorter periods. Individuals with earnings that grow faster than those in the economy as a whole will lose from the change in earnings measure. For example, a worker with $1 \%$ earnings growth ahead of the average would lose $9.1 \%$ as a result of the change in earnings measure in Poland, $17.7 \%$ in the Slovak Republic and 13.2\% in Sweden. 
These calculations should be borne in mind when looking at the overall effect of reforms, since the baseline assumptions understate the impact of changes on workers whose earnings grow faster than the economy-wide average across the career. ${ }^{7}$

\section{Links between earnings and benefits}

This section examines how pension reforms have changed the links between earnings and benefits. While the previous section focussed on the relative position of low-income retirees, this part looks more broadly at the degree of redistribution across the entire earnings range.

The analysis uses the index of pension benefit progressivity, which is described in detail in Part I. It is designed in the following way: a basic pension scheme which pays the same benefit to everyone scores $100 \%$ and is maximally progressive. A pure insurance scheme that pays benefits which correspond to previous earnings scores zero. It has no progressivity because it pays the same replacement rate to everyone.

The impact of pension reforms is shown in Figure II.1.1, which presents the pre- and post-reform progressivity indices for the 16 countries. Several countries have made their pension systems more progressive; these are shown on Panel A. The strongest increases are found in Mexico, Portugal and in the United Kingdom. In Mexico, this results from the combination of the government subsidy and the minimum pension. In Portugal, the minimum pension compensates part of the benefit cuts for low-income earners leading to a more progressive benefit structure. In the United Kingdom, the higher redistribution results from the new rules that protect pension benefits for low-income earners; these rules were discussed in the previous section. Smaller increases in progressivity occurred in Austria and France. In Germany, there is only a small increase in progressivity due to the fact that the old-age safety nets remained in place, albeit at a low level, while earningsrelated pension benefits were cut.

As expected, strong declines in progressivity can be observed in countries that replaced all or parts of their old pension systems with notional or funded DC schemes (Slovak Republic, Poland, Hungary; see Panel B). All four countries have post-reform indices of progressivity fairly close to zero; this shows that they have indeed moved to or are very close to the pure insurance model with a strong link between pensions and earnings. The Swedish pension reform, despite the large notional-accounts component and the mandatory DC element of the new system, has not made the overall system less progressive than the old system; this is due to the replacement of the previous universal basic pension, which was paid to all income groups, with a targeted pension available only to lower-income retirees.

In Italy, the reform abolished the previously existing minimum pension although there remains a social-assistance benefit as a safety net; the link between earnings and benefits was already strong in the old system. This explains why the reform did not change progressivity much despite the introduction of the new notional defined-contribution scheme. The old Hungarian scheme also had a minimum pension but this will not be paid beyond 2009 and was thus not included in the post-reform model. In Poland, the fall in progressivity is due to the removal of the basic pension component.

The largest change took place in the Slovak Republic where practically all redistribution was removed from the pension system. The old Slovak pension system had a ceiling on the value of pension benefits that effectively capped pensionable earnings just 
Figure II.1.1. Index of progressivity of benefit formula before and after reforms Gini coefficient of pension entitlements relative to Gini coefficient on earnings
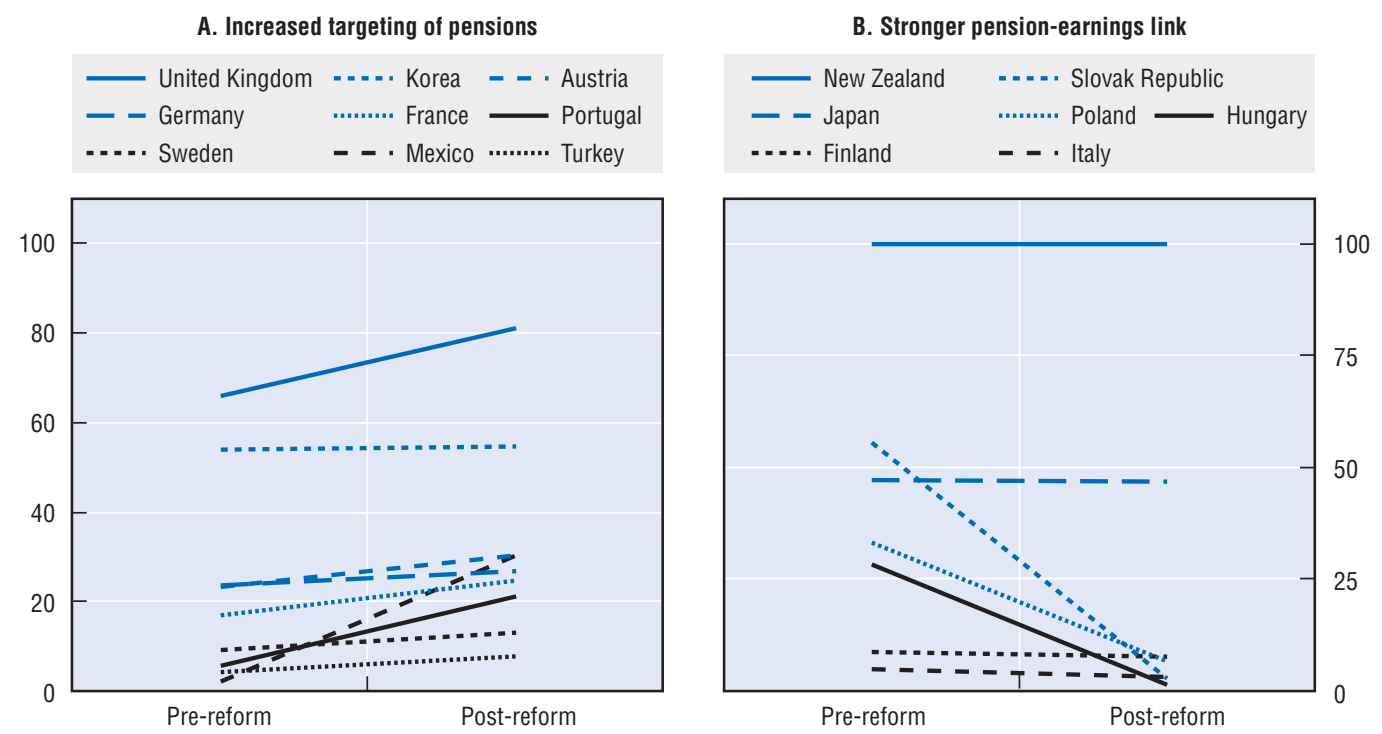

Note: For a detailed definition of the index, see the section on "Progressivity of Pension Benefit Formulae" in Part I. Source: OECD pension models.

above economy-wide average earnings. This meant that higher-income workers received a proportionately smaller benefit than low-income workers. The new two-tiered system follows the insurance model: it has a tight link between earnings and benefits in both components. The earnings-related scheme is based on pension points resulting in a uniform accrual rate for all workers. There is no minimum pension anymore; instead, a minimum income is used for pension benefit calculations. Finally, the DC component obviously has a strict earnings-benefit link. The most relevant change for progressivity is the introduction of a ceiling on pensionable earnings nearly three times as large as the effective ceiling under the old system.

\section{Rebalancing public and private provision}

Five OECD countries (Hungary, Sweden, Poland, the Slovak Republic and Mexico) have reset the balance between public and private pension schemes. Figure II.1.2 shows how reforms have affected the composition of the average pension level and average pension wealth (i.e. the discounted stream of average future pension payments) from public and private sources.

The most radical change took place in Mexico where all of the pension system was public before the reform and now only a small public component is retained. Three other countries, Hungary, Poland and the Slovak Republic, also started with an entirely public system before the reforms and moved to mixed systems. In Poland and the Slovak Republic, now more than half of the pension promise is delivered through the private sector, while in Hungary the public scheme still accounts for more than $60 \%$.

Sweden stands out in this group of countries, since private employer-based pension schemes have always been important in pension provision. After the pension reform, the 
Figure II.1.2. The changing public private balance

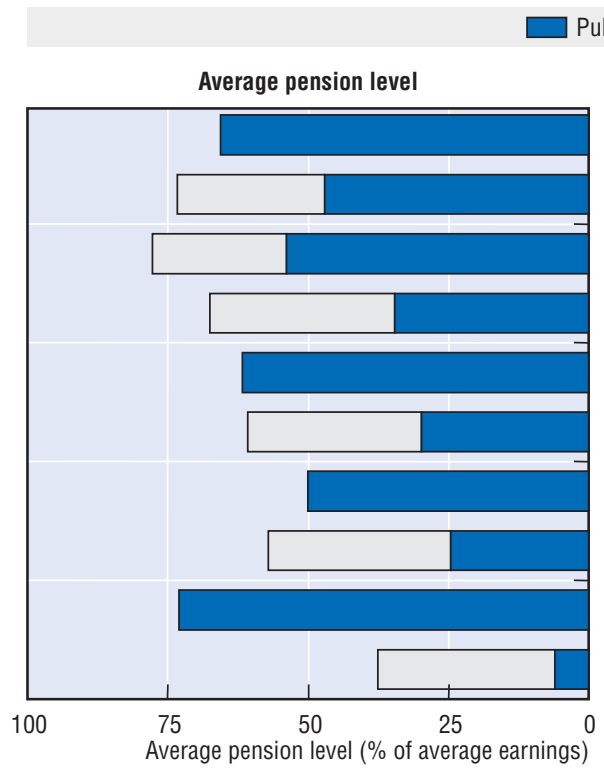

Public Private

Before
Hungary
After
Before
Sweden
After
Before
Poland
After
Before
After
Before
Mexico
After

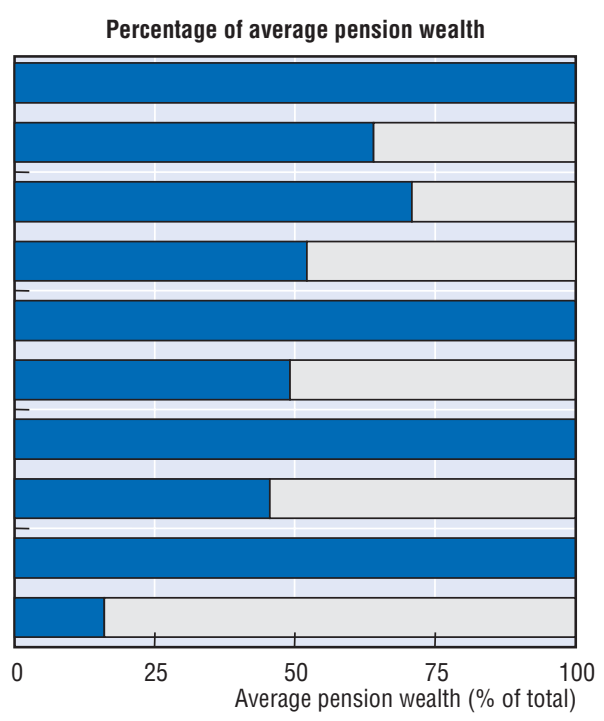

StatLink तiा hts http://dx.doi.org/10.1787/565066581031

private component increased to just under $50 \%$ of the pension promise. This was achieved partly by introducing a new mandatory, privately-managed DC component.

\section{Adjustments to life-expectancy changes}

Countries that have introduced DC or notional accounts components into their pension system have an automatic adjustment to life expectancy in these schemes. Others have introduced or proposed links to life expectancy in their traditional DB public schemes. The effects of these adjustments differ depending on their precise design and on the offsetting impact of other parts of the retirement-income regime that are not linked to life expectancy (see Whitehouse, 2007b).

Table II.1.6 summarises how the projected change in mortality between 2002 and 2040 (the years covered in the UN/World Bank population database) would affect pension benefits in a selection of OECD countries that link pensions to life expectancy. On average, life expectancy at age 65 is projected to grow by 3.2 years for the ten countries shown. The projections are based on an assumption of convergence of mortality rates. Life expectancy is predicted to increase by just 2.5 years in Sweden - which had the longest life expectancy in 2002 - and by more than 3.5 years in the three Central and Eastern European countries, which all had life expectancy at age 65 of less than 80 years in 2002.

In all cases, the life-expectancy link will reduce average pension levels. The fall averages around $10 \%$ in the nine countries shown. At the same time pension wealth is projected to increase, because not all parts of the pension system are affected. The increase averages almost 7\% across countries. Italy, Mexico and Poland have the smallest increase in pension wealth over the period, reflecting the very strong links there between life expectancy and pensions. In Hungary and the Slovak Republic, there remain large public pension schemes that are not linked to life expectancy and so pension wealth increases as mortality improves. 
Table II.1.6. Effects of forecast improvements in life expectancy (2002-2040) on pension benefits in selected OECD countries ${ }^{1}$

\begin{tabular}{lccc|ccc|rrr}
\hline & \multicolumn{3}{c}{ Total life expectancy at age 65 } & \multicolumn{3}{c|}{$\begin{array}{c}\text { Average pension level } \\
\text { (\% of average earnings) }\end{array}$} & \multicolumn{3}{c}{$\begin{array}{c}\text { Average pension wealth } \\
\text { (multiple of earnings) }\end{array}$} \\
\cline { 2 - 10 } & 2002 & 2040 & Change & 2002 & 2040 & Change & 2002 & 2040 & Change \\
\hline Australia & 82.8 & 85.6 & $+15.5 \%$ & 44.7 & 42.6 & $-4.7 \%$ & 6.5 & 7.2 & $+10.8 \%$ \\
Denmark & 81.0 & 84.5 & $+21.7 \%$ & 87.1 & 79.3 & $-9.0 \%$ & 11.3 & 12.4 & $+9.7 \%$ \\
Finland & 81.8 & 85.4 & $+21.5 \%$ & 69.9 & 61.9 & $-11.4 \%$ & 9.0 & 9.7 & $+7.4 \%$ \\
Hungary & 78.9 & 82.7 & $+27.8 \%$ & 79.6 & 73.4 & $-7.8 \%$ & 10.3 & 11.9 & $+15.5 \%$ \\
Italy & 82.3 & 84.9 & $+15.1 \%$ & 73.1 & 65.0 & $-11.1 \%$ & 9.4 & 9.5 & $+1.1 \%$ \\
Mexico & 80.5 & 82.6 & $+13.7 \%$ & 41.0 & 37.6 & $-8.3 \%$ & 4.9 & 5.0 & $+2.0 \%$ \\
Poland & 79.7 & 83.4 & $+25.2 \%$ & 74.6 & 60.7 & $-18.6 \%$ & 8.2 & 8.3 & $+1.2 \%$ \\
Portugal & 80.8 & 84.4 & $+22.9 \%$ & 67.9 & 56.3 & $-18.9 \%$ & 8.2 & 8.3 & $+1.2 \%$ \\
Slovak Republic & 79.4 & 82.9 & $+24.2 \%$ & 63.2 & 57.1 & $-9.7 \%$ & 8.0 & 8.9 & $+11.3 \%$ \\
Sweden & 83.3 & 85.8 & $+13.4 \%$ & 72.3 & 67.4 & $-6.8 \%$ & 10.4 & 10.8 & $+3.8 \%$ \\
\hline
\end{tabular}

Note: Change in life expectancy is given as a percentage of additional life expectancy at 65 and not in total life expectancy at 65 . Based on unisex mortality rates.

1. These OECD countries have introduced LE adjustment.

Source: OECD pension models; UN/World Bank population database.

\section{Reducing the long-term pension promise}

One of the main objectives of pension reforms in OECD countries has been to cut public pension expenditures and make pension systems financially sustainable in the face of population ageing. Indeed, as Table II.1.1 showed, most common changes to pension systems, such as less generous indexation and/or valorisation, changes in retirement age, changes in the earnings measure, and so on, have had this effect.

To illustrate the extent of financial and fiscal consolidation, the value of the pension promise is compared for pre- and post-reform systems. Again, it is worth noting that, just because a pension system was legislated, does not mean that it would have been paid. Prereform systems would often have proved unaffordable in the long term, so this indicator can be thought of as illustrating the extent of change necessary to put pensions on a firm, long-term financial footing.

The comparison is based on the indicator of weighted average pension wealth. This is the most comprehensive measure of the scale of the pension promise made to today's workers because it takes account of differences in life expectancy, pension eligibility ages and indexation of pensions in payment. The calculation is described in detail in the section on weighted average pension levels and pension wealth in Part I of this report.

The impact of reform on the cost of the pension promise is shown in Figure II.1.3 for men (Panels A and B) and women (Panels $C$ and D). It can be seen that by far the largest cost-cutting occurred in Mexico for male workers and, to an even greater extent, for female workers. As discussed earlier, benefits were cut substantially through the move from the old system dominated by the DB scheme to the new system which relies almost entirely on a DC scheme. The decline is larger for women since the benefit in the old system was not adjusted to women's higher life expectancy; pension wealth was higher because women live longer. Under the new scheme, women have the same retirement age as men and annuities are calculated with sex-specific mortality tables which equalise pension wealth from the DC scheme for men and women. The minimum pension component, however, is not sex specific and thus women have a slightly higher pension wealth than men. 


\section{Figure II.1.3. Average pension wealth before and after reforms}

Multiple of economy-wide average earnings

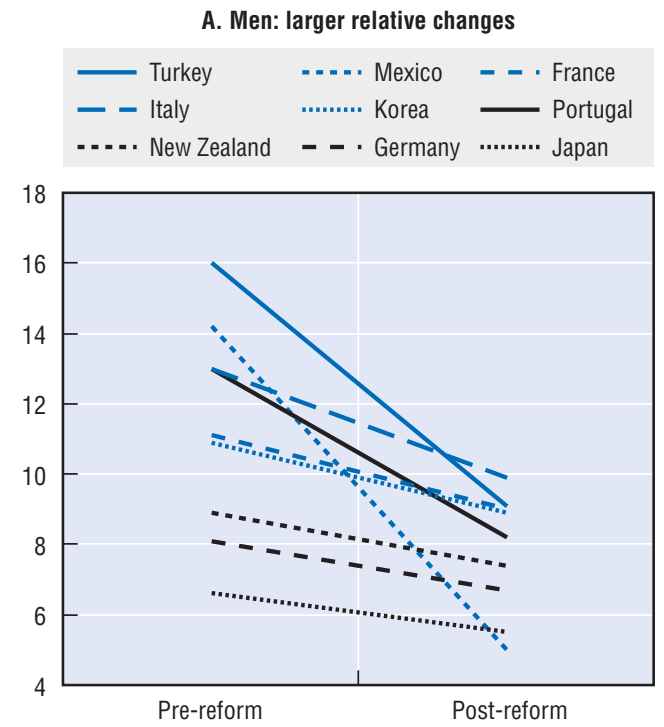

B. Men: smaller relative changes

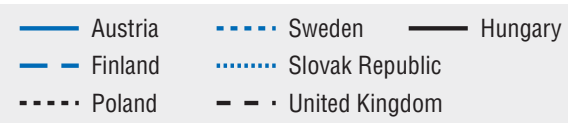

-.... Poland _ - - United Kingdom

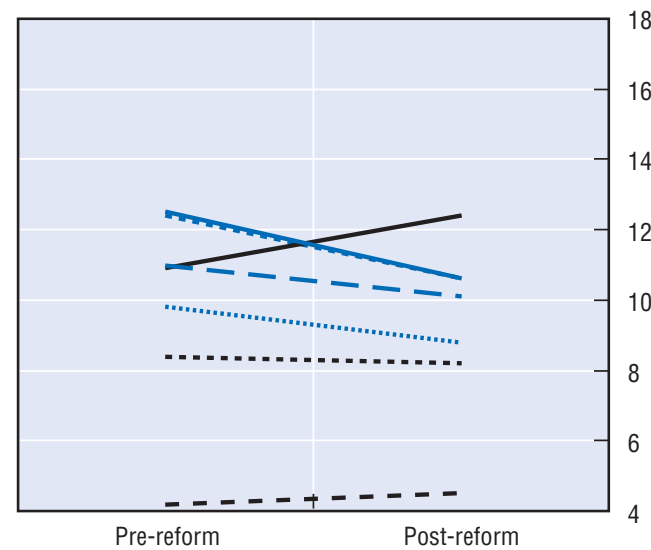

C. Women: larger relative changes

\section{Women: smaller relative changes}
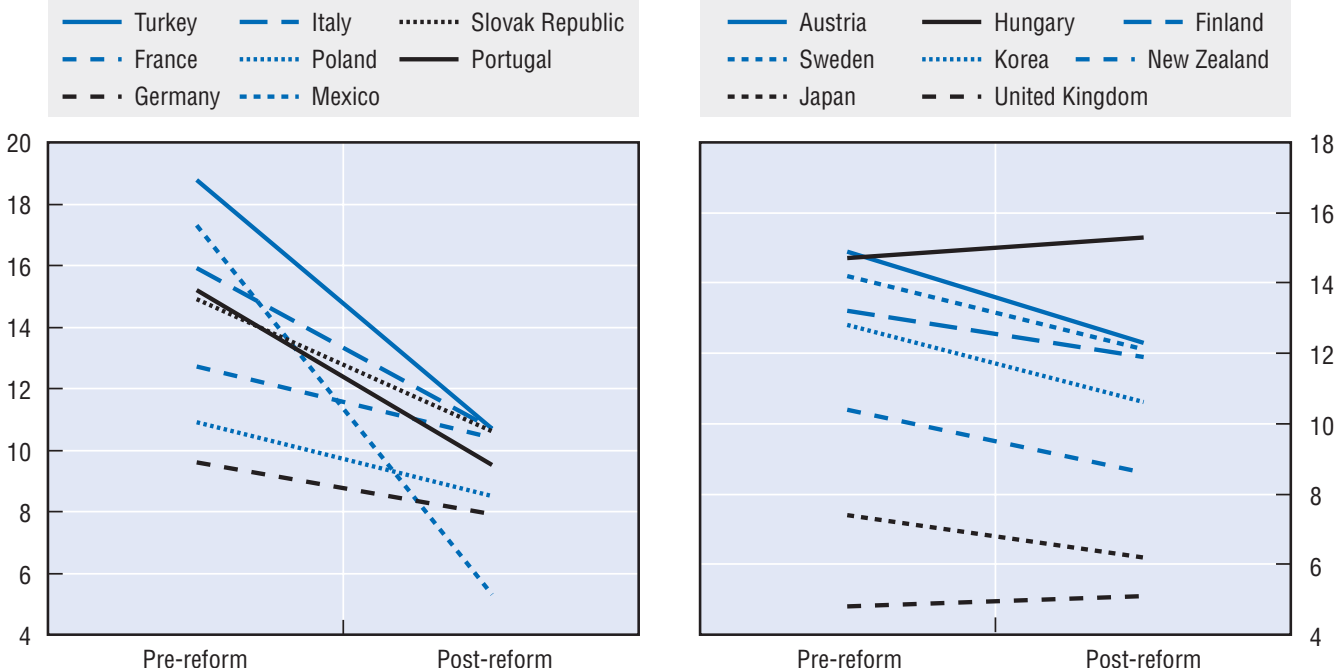

Note: The charts show the weighted average pension wealth (with the weights reflecting the distribution of earnings) See the section on "Weighted averages: pension levels and pension wealth" in Part I.

Source: OECD pension models.

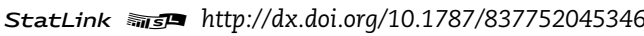

In Italy, post-reform pension ages are the same for men and women, but they were different before the reforms. Thus, women experience even greater losses in pension wealth compared to men than they would only on the basis of the difference in life expectancy.

In the new Polish pension system, the retirement age for women is still lower than for men. Women therefore accumulate fewer contributions and retire on a lower benefit. Since life expectancy of women is higher, however, women still have slightly higher pension wealth than men. In the Slovak Republic, pension ages for men and women were increased 
to a uniform 62 years, though the reduction in cost from this measure is not very strong since pension levels did not fall by as much as in the other countries. In Japan and Austria, the cuts in the benefit accrual rate also helped lower costs. In Austria, more years of accrual will actually increase the benefit for women, but the higher retirement age and thus shorter retirement period for women will lead to an overall reduction in pension wealth compared to the pre-reform system.

In Finland and Germany, changes in valorisation and post-retirement indexation played an important role. Women's pension wealth is still higher than that of men but the losses experienced as a result of the reforms are broadly the same for both sexes.

Only in the United Kingdom did weighted average pension wealth increase. This was due to changes in replacement rates, particularly for lower-income retirees. The increase was stronger for women than for men due to higher life expectancy of women.

\subsection{Conclusions}

Nearly all the 30 OECD countries have made at least some changes to their pension systems since 1990. There have been major reforms that will significantly alter future retirement benefits in over half of them. This chapter has outlined eight different types of change to pension schemes that make up recent pension reforms. Some, such as increases in pension ages, are highly visible and controversial. Others, such as changes in the way in which earnings are measured when calculating benefits, are more complex and technical but, nonetheless, can have a huge impact on benefits.

The reform packages, like pensions systems themselves, had diverse and complex features. However, there is a clear underlying trend towards a reduced pension promise for today's workers compared with past generations. The average pension promise in the 16 countries studied fell from 10.7 times annual earnings to 8.4 times for men, a cut of $22 \%$. For women, the reduction is larger: from 13 times annual earnings to 9.7 times, equivalent to a reduction of $25 \%$. Only in two of the 16 countries - Hungary and the United Kingdom were there increased pension promises on average.

Who reformed pensions and who did not? Six of the ten countries with the highest public expenditures on pensions in 1990 - Austria, France, Germany, Italy, Sweden and Finland (ordered from highest to lowest spenders) - have seen major reforms of their pension systems since 1990. However, the rest of the top ten have seen little or no change to their retirement-income regimes over that period. This group consists of Greece, Luxembourg, Belgium and Spain, whose pension expenditures in 1990 averaged $9.5 \%$ of GDP, compared with $6.7 \%$ for the OECD as a whole.

Substantial pension reforms occurred almost as often in the ten OECD countries that had the lowest pension expenditures in 1990 as they did among those already facing a heavy fiscal burden. This group of reformers consists of Japan, Korea, Mexico and Turkey. In Japan, the need for change results from the pace and scale of demographic change: expenditures already increased from 5\% of GDP in 1990 to 9.3\% in 2003. In Korea, Mexico and Turkey, pension systems are less mature and the demographic situation is currently more favourable than elsewhere in the OECD. Population ageing in Korea is expected to be very rapid. In Mexico and Turkey, the pre-reform systems were very generous, with average pension wealth of around 15 times annual earnings for men and 18 times for women, compared with the OECD averages of 9 and 11 times earnings respectively. Reforms were therefore necessary in these countries even though current pension spending is not especially large. 
An assessment of pension reforms in OECD countries cannot and should not be made on fiscal criteria alone. For example, pension reforms also have profound social and distributional implications: how will the changes affect different individuals? The answer is complex. Some countries - such as France, Portugal and the United Kingdom - are moving towards greater targeting of public pensions on low earners. Others - such as Poland and the Slovak Republic - have moved to tighten the link between pension entitlements and earnings when working to improve work incentives and compliance. This has important implications for the future adequacy of retirement incomes for low earners. In Germany, Japan, Mexico, Poland and the Slovak Republic, the net pension entitlement for a full-career worker with half average earnings was around $41 \%$ of average earnings before reform, slightly below the average for the OECD as a whole. The reforms will cut this to just $32.5 \%$. There is therefore a risk of a resurgence in old-age poverty in some countries. In contrast, Finland, France, Hungary, Korea, New Zealand and the United Kingdom have protected low-income workers from cuts in benefit in their pension reforms.

Reforming pensions is undoubtedly both a challenging and controversial issue because it involves long-term planning by governments faced with numerous short-term pressures. This chapter has shown that pension reform is not, however, politically impossible. Countries that have yet to embark on necessary changes to retirement-income provision can learn valuable lessons from those that have already made the journey.

\section{Notes}

1. Examples of this approach include Economic Policy Committee (European Union, 2005, 2006), Salomaki (2006) and Dang et al. (2001).

2. McHale (1999) is one example.

3. This is because the reform required employers to provide private pensions, of which coverage was already widespread before the reform. Therefore, comparing only the mandatory parts of the new system with a pre-reform scenario with only the public pension would be misleading.

4. Note that indexation of pensions in payment is often confused in the public debate with "valorisation", that is the adjustment of earlier years' earnings to reflect price and wage inflation up to the date of retirement.

5. Between 2000 and 2005, the basic pension increased by $7.9 \%$ in real terms, keeping its value constant at $15.9 \%$ of average earnings on the national measure (Department of Work and Pensions, 2006b, Table 5.1).

6. Individual earnings in any time period i can be expressed as a multiple of earnings in the base period (w0): $\mathrm{w}_{\mathrm{i}}=\mathrm{w}_{0}(1+g)^{i}$, where $\mathrm{w}$ is earnings and $\mathrm{g}$ is the growth of (individual and economywide) earnings. Revaluing pay in line with earnings growth gives for each period: $\mathrm{w}_{\mathrm{i}}=\mathrm{w}_{0}(1+g)^{i}(1+g)^{R-i}$. This is constant over time and so final and lifetime average revalued earnings are equal in this case.

7. Figure 3.4 in OECD (2006b) shows that average earnings of $60-64$ year old men are $136 \%$ of those of 25-29 year olds, implying annual career earnings growth that averages about $0.8 \%$ above the economy-wide average. For women, the ratio of older workers' wages to younger is $112 \%$, implying annual career growth of $0.3 \%$, should this pattern hold in the future. 


\title{
2. The Role of Private Pensions in Providing Future Retirement Incomes
}

\begin{abstract}
Crost ross-country analysis of retirement-income regimes cannot ignore the important and growing role that private pensions play in providing for old age. In 11 OECD countries Australia, Denmark, Hungary, Iceland, Mexico, Norway, Poland, the Slovak Republic, Sweden, Switzerland and the United Kingdom - the private sector delivers part of the mandatory provision for income in old age. Furthermore, in six of these - Australia, Hungary, Mexico, Norway, Poland and the Slovak Republic - the private sector's involvement dates only from the 1990s. As well as the spread of mandatory private pensions, $40 \%$ or more of the workforce is covered by voluntary private pensions in nine OECD countries.
\end{abstract}

Section 2.1 of this chapter on private pensions looks at the extent of mandatory private retirement-income provision under both voluntary and mandatory plans. Section 2.2 explores the changing nature of private pension provision. Private pensions have traditionally been employer-provided and been of the defined-benefit (DB) type, where the entitlement depends on some measure of individual earnings and years of service. But in a number of countries, defined-benefit pensions are now disappearing to be replaced by defined-contribution (DC) plans. The pension benefit in DC plans depends on the value of individual and employer contributions, the investment returns that these earn and the terms on which accumulated retirement-income capital can be converted into a flow of pension benefits.

Sections 2.3 and 2.4 focus on the balance between mandatory and voluntary provision for retirement. The analysis measures the scale of the "retirement-savings" gap: the role that voluntary pensions should play when mandatory pensions are relatively low.

The proportion of earnings that need to be contributed to fill the retirement-savings gap is calculated in Section 2.5. Sections 2.6 and 2.7 show how this depends crucially on the years over which people contribute and the rate of return on the funds invested in the pension plan.

Section 2.8 compares replacement rates between countries where retirement savings are almost wholly mandatory and those where voluntary savings are important.

\subsection{Coverage of private pensions}

Table II.2.1 shows the types of pension scheme offered in different countries. It also shows data on the proportion of people who are covered and the average (or typical) contribution rate. Where countries also have DB plans, the data on contribution rates refer only to DC schemes. Information is shown for the two main type of private pension scheme in each country. 
Unfortunately, data on coverage of private pensions can be extremely difficult to obtain and is often difficult to compare because of institutional differences in the markets for long-term savings. Table II.2.1, therefore, draws on a number of sources and the estimates shown should be regarded as preliminary.

Table II.2.1. Types of private pension scheme, coverage and average contribution rates

\begin{tabular}{|c|c|c|c|c|c|c|}
\hline & \multicolumn{3}{|c|}{ Largest scheme } & \multicolumn{3}{|c|}{ Second largest scheme } \\
\hline & Scheme & Coverage & Contribution & Scheme & Coverage & Contribution \\
\hline Australia & $\mathrm{MO} / \mathrm{P}$ & $>90 \%$ & $9 \%$ & & & \\
\hline Austria & vo & $35 \%$ & $1.5-2 \%$ & VP & $10 \%$ & - \\
\hline Belgium & vo & $40-50 \%$ & $1-5 \%$ & & & \\
\hline Canada & vo & $39 \%$ & $8.5 \%$ & VP & $50 \%$ & - \\
\hline Czech Republic & VO/P & $40 \%$ & $2.8 \%$ & & & \\
\hline Denmark & $\mathrm{MP}$ & $>90 \%$ & $1 \%$ & QM0 & $>80 \%$ & $10.8-17 \%$ \\
\hline Finland & VP & $15 \%$ & $3 \%$ & vo & $7 \%$ & $2 \%$ \\
\hline France & vo & $10 \%$ & & VP & $8 \%$ & \\
\hline Germany & V0 & $57 \%$ & $2-4 \%$ & VP & $13 \%$ & $2-4 \%$ \\
\hline Greece & VO/P & negligible & - & & & \\
\hline Hungary & $\mathrm{MP}^{1}$ & $58 \%$ & $8 \%$ & VO/P & $31 \%$ & $5 \%$ \\
\hline Iceland & MO & $>90 \%$ & $10 \%$ & & & \\
\hline Ireland & VO/P & $52 \%$ & c. $10 \%$ & & & \\
\hline Italy ${ }^{2}$ & vo & $8 \%$ & $2.35 \%$ & VP & $2 \%$ & - \\
\hline Japan $^{3}$ & vo & $45 \%$ & & & & \\
\hline Korea & vo & negligible & & & & \\
\hline Luxembourg & vo & $20 \%$ & - & VP & $5 \%$ & $4 \%$ \\
\hline Mexico & MP & $31 \%$ & $6.275 \%$ & & & \\
\hline Netherlands & QMO & $>90 \%$ & - & & & \\
\hline New Zealand & vo & $20 \%$ & - & & & \\
\hline Norway & MO & $>90 \%$ & $2 \%$ & vo & $45 \%$ & - \\
\hline Poland & $\mathrm{MP}^{1}$ & $49 \%$ & $7.3 \%$ & VO/P & negligible & - \\
\hline Portugal & vo & $4 \%$ & $3 \%$ & VP & $1.5 \%$ & - \\
\hline Slovak Republic & $\mathrm{MP}^{1}$ & $45 \%$ & $9 \%$ & VP & $27 \%$ & $5.4 \%$ \\
\hline Spain & VP & $40 \%$ & - & V0 & $10 \%$ & - \\
\hline Sweden & MP & $>90 \%$ & $2.5 \%$ & QMO & $>90 \%$ & $2 \%$ \\
\hline Switzerland & MO & $>90 \%$ & $7-18 \%$ & & & \\
\hline Turkey & Vo/P & negligible & - & & & \\
\hline United Kingdom ${ }^{4}$ & vo & $43 \%$ & c. $9 \%$ & VP & $16 \%$ & - \\
\hline United States & vo & $47 \%$ & c. $9 \%$ & VP & $17 \%$ & \\
\hline
\end{tabular}

$\mathrm{M}=$ mandatory.

$\mathrm{O}=$ occupational (employer-based).

$\mathrm{P}=$ personal (individual-based).

$\mathrm{QM}=$ quasi-mandatory (coverage through collective agreements).

$\mathrm{V}=$ voluntary.

Note: The contribution rates shown are for DC plans in countries where there are also DB occupational schemes (Canada, Ireland, Sweden, United Kingdom, United States).

1. Membership is compulsory for new labour-market entrants (and sometimes for younger workers) in these countries but optional for existing workers. Coverage will therefore tend towards $100 \%$ over time.

2. The severance pay scheme, known as TFR, can be converted into a retirement-savings plan. Contribution rates are $6.91 \%$ for new workers and $2.41 \%$ for existing workers. Severance-payment schemes - which may be used to finance retirement - are also important in Japan and Korea.

3. This shows the total covered by tax-qualified pension plans, employees' pension fund or both.

4. The schemes shown are those that are contracted out of the state second pension. Thus, part of the benefits from these schemes is a component of mandatory retirement-income provision.

Source: OECD Private Pension Statistics; European Union, Social Protection Committee (2005); Copeland (2006); Schembari (2004); Palacios and Pallares-Miralles (2000); Government Actuary's Department (2005, 2006); national authorities. 
The table shows that 11 OECD countries have mandatory (or quasi-mandatory) private pensions. Eight of these countries have private pensions of the DC type. In the Netherlands, $97 \%$ of members of the quasi-mandatory occupational pension schemes are covered by a DB scheme (with the remainder in DC plans). In Iceland and Switzerland, the mandatory occupational plans work in a similar way. Both are based on a mandatory contribution level, a statutory interest rate and a statutory annuity rate. These are therefore closer to DB (and other kinds of earnings-related scheme) than they are to DC plans as normally understood by the term.

Coverage of mandatory and quasi-mandatory pension schemes usually exceeds $90 \%$ of employees. However, in Hungary, Poland and the Slovak Republic, only younger workers and/or new labour-market entrants were required to join the new private pension schemes. Some existing workers were able to choose between remaining solely in the public, earnings-related scheme or switching to mixed public/private-DC provision. Hence, coverage of these programmes is between 45 and $60 \%$ of the current workforce, but this will rise over time to the whole labour force. ${ }^{1}$

The rest of this chapter focuses on voluntary private pension provision: voluntary in the sense that either employers do not have to provide an occupational plan or that individuals do not have to join a personal plan. The relevant coverage rates for voluntary pensions from Table II.2.1 are summarised in Figure II.2.1, which gives a clearer picture of the differences between countries. In four countries - Germany, Ireland, the United Kingdom and the United States - coverage of voluntary, private pensions exceeds half of the workforce. This is mainly through employer-provided schemes, but personal plans also play an important role in all four countries. Covering around $45 \%$ of workers, voluntary private pensions are also widespread in Belgium, Japan and Norway. At the other end of the chart, $10 \%$ or fewer workers are covered by voluntary, occupational, private pensions in Finland, Italy, Portugal and Spain.

Figure II.2.1. Coverage of voluntary private pensions

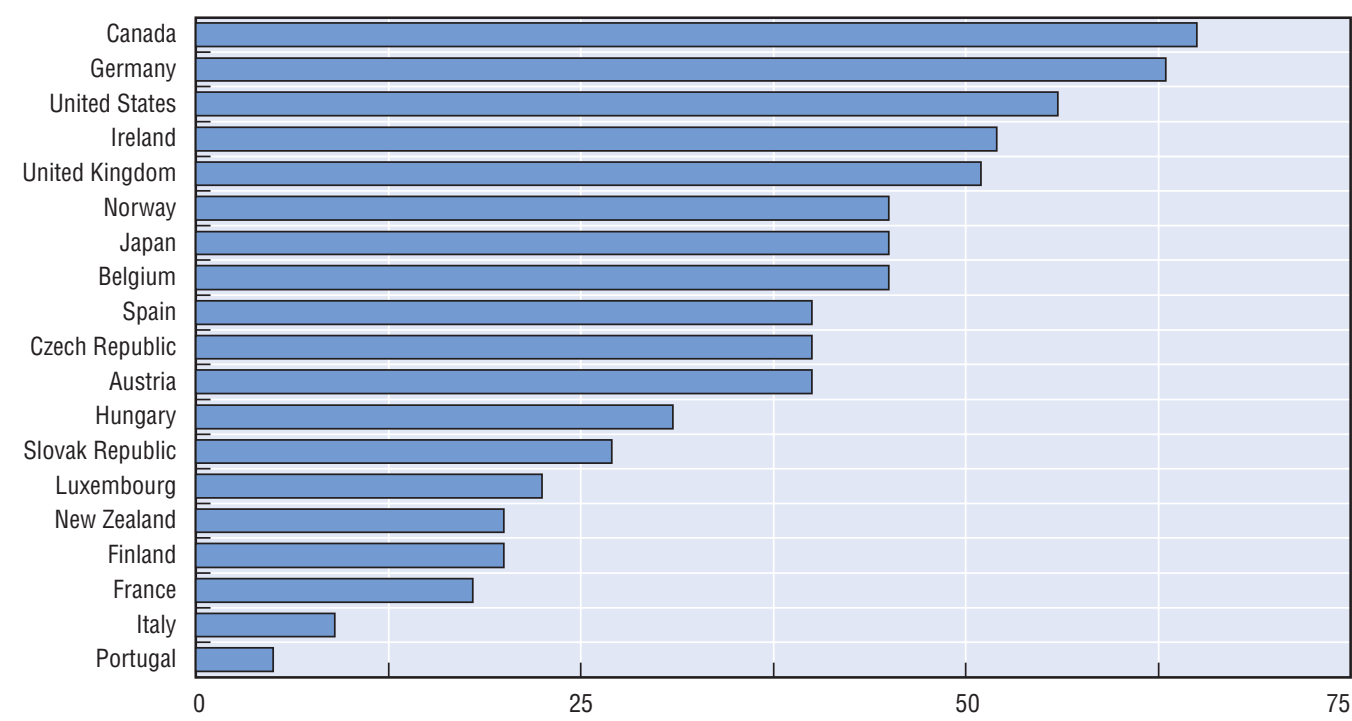

Note: See notes to Table II.2.1.

Source: OECD Private Pension Statistics; European Union, Social Protection Committee (2005); Copeland (2006); Schembari (2004); Palacios and Pallares-Miralles (2000); Government Actuary's Department (2005, 2006); national officials. 
As mentioned at the outset, measuring coverage of private pensions is an inexact science. Data on coverage of personal, voluntary, private pensions is especially difficult to obtain and institutional differences are even more significant than they are for voluntary, occupational pensions. For example, Table II.2.1 does not contain data on personal pension coverage in Australia, Belgium, Japan and New Zealand, where some sources suggest that this is widespread.

\subsection{Types of voluntary private pension provision}

The first edition of Pensions at a Glance modelled pension entitlements for members of occupational, defined-benefit pension plans in only three countries: Canada, the United Kingdom and the United States. These countries were chosen for three reasons: first, the breadth of occupational-pension coverage; secondly, the important role that private pensions already play in providing retirement incomes; and, thirdly, availability of data on the rules and parameters of different employers' plans for these countries. However, there has been a shift ${ }^{2}$ from DB to DC pensions in these three countries for workers in the private sector and more limited change in Ireland.

\section{Canada}

Statistics Canada reports a decline in occupational-pension coverage since the early 1980s. Among men, for example, the proportion of employees covered fell from $55 \%$ in the early 1980 s to $42 \%$ in 2000 . The proportion of women covered increased slightly from 37 to $39 \%$ over the same period (Morissette and Johnson, 2003). The survey of occupational pension schemes shows rapid growth in coverage of DC pensions - membership up 180\% between 1993 and 2003 - albeit from a small base. Overall, DC plans increased their share of members from $9 \%$ in 1993 to 15\% in 2003. In the private sector, DC schemes accounted for $24 \%$ of members in 2003 compared with $14 \%$ a decade earlier.

This, however, understates the shift from DB to DC provision. Many employers now offer group personal pensions (known as registered retirement savings plans or RRSPs) instead of traditional occupational plans. Unfortunately, the degree to which this has offset the decline in occupational pension coverage cannot be determined because of lack of suitable data (Schembari, 2004).

\section{Ireland}

Between 1999 and 2005, the number of people in occupational pensions increased by nearly $30 \%$, according to the Pensions Board. However, the number in DC plans grew by $63 \%$ while DB schemes added only $18 \%$ more members. Moreover, most of the growth of DB coverage occurred in the public sector. The number of members of DB schemes (broadly) in the private sector (defined formally as those subject to the funding requirement) increased by just $5 \%$. The proportion of members of occupational scheme in the private sector covered by DC arrangements increased from less than $40 \%$ in 1999 to $50 \%$ in 2005 .

\section{United Kingdom}

There has been a substantial decline in private-sector, DB occupational plans. These covered $23 \%$ of total employees the United Kingdom in 1988-89, nearly halving to $12 \%$ in 2002-03. In contrast, the proportion of the workforce in public-sector defined-benefit plans remained broadly constant over most of the period, with a recent increase to $19 \%$ 
reflecting the expansion of the public sector. This meant that the number covered by private occupational plans fell below those in public plans in 1994-95 (Department of Work and Pensions, 2006a).

According to the Government Actuary's Department (2006), the number of members of private-sector DB plans fell from 4.8 million in 2000 to 3.7 million in 2005. The decline in DB occupational plans in the private sector appears to have accelerated recently: $42 \%$ of active members of private-sector, DB plans are in schemes that are closed to new members. In 2003-04 alone, 0.25 million people left these closed plans (either to retirement or to another job) while a net 50000 were lost from open schemes. This 0.3 million fall is equivalent to a loss of $14 \%$ of total members in a single year.

\section{United States}

The shift from DB to DC private pensions began earlier in the United States than elsewhere. By 1980, for example, some $32 \%$ of active members of an occupational pension scheme were covered by a DC plan. This proportion doubled over the next 15 years to reach $64 \%$ by 1995 and grew further to 71\% by 2003 (US Department of Labor).

\section{The changing structure of private pension provision}

The shift from providing occupational pensions through DB schemes to a DC model has reached different stages in different countries. Many workers are still covered by DB plans, but this is increasingly a legacy from the past. Coverage will diminish rapidly because many schemes are now closed to new members. In countries which retain predominantly DB occupational pension coverage - such as Iceland, the Netherlands and Switzerland - this tends to result from government mandates or provision is quasi-mandatory as a result of industrial-relations agreements.

The framework of Pensions at a Glance is forward-looking at it considers workers in the private sector. Very few, if any, individuals entering the labour market today in the countries discussed above will join a DB pension scheme and remain a member of such a plan for their whole working lives. The rest of this chapter, therefore, focuses on DC pension plans. ${ }^{3}$

\subsection{Mandatory replacement rates and the pension savings gap}

Figure II.2.2 shows again the projected gross replacement rate for the average earner with a full career, which ranges from $31 \%$ of individual earnings in the United Kingdom to $96 \%$ in Greece (see Part I, "Gross pension replacement rate"). The average gross replacement rate for the 30 OECD countries is almost $59 \%$.

The analysis that follows focuses on the 11 countries at the bottom of the chart that have below-average mandatory replacement rates. What level of voluntary, private pension savings would be needed to deliver an overall gross replacement rate in these countries that equalled the OECD average? This is obviously an arbitrary target but it is illustrative to set a benchmark relative to all OECD countries, including those with mainly mandatory retirement provision.

The difference between the national mandatory replacement rate and the OECD average is here called the "retirement-savings gap". Along with all six of the mainly English-speaking members of the OECD - Australia, Canada, Ireland, New Zealand, the United Kingdom and the United States - mandatory gross replacement rates are below the OECD average in four continental European countries - Belgium, the Czech Republic, France and Germany - and in Japan. ${ }^{4}$ 
In the United Kingdom, private pension savings would need to deliver a replacement rate of $28 \%$ to bring the overall pension up to the level of the OECD average. France has the smallest retirement-savings gap of the 11 countries analysed: $7.5 \%$. For the 11 countries as a whole, the replacement rate from mandatory pensions is $40.6 \%$ for average earners, giving a retirement-savings gap of $18.2 \%$ on average (relative to the OECD average gross replacement rate for an average earner of $58.7 \%$ ).

\section{Figure II.2.2. The retirement-savings gap}

Gross replacement rate for an average earner from mandatory pension schemes and difference from OECD average replacement rate

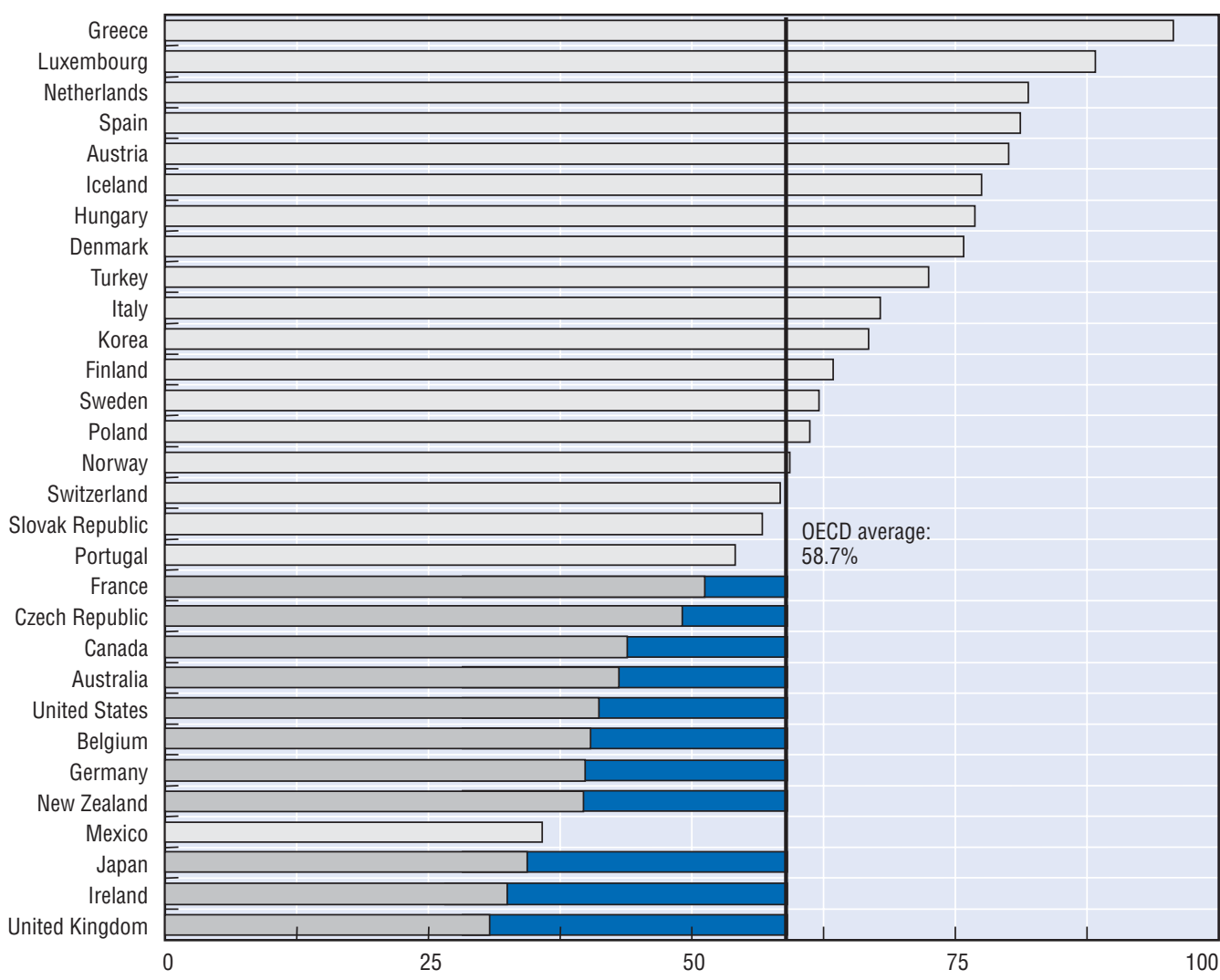

Source: OECD pension models.

\subsection{Mandatory replacement rates and private-pension coverage}

Do individuals respond to lower replacement rates from mandatory pensions by making voluntary, private provision for retirement? Figure II.2.3 combines the evidence on coverage of private pensions from Table II.2.1 and Figure II.2.1 with the projections of the replacement rates from mandatory pensions for average earners, which were shown in Figure II.2.2. Two clusters of countries are readily apparent in Figure II.2.3.

First, there is a range of mainly Southern European countries - Greece, Italy, Portugal, Spain and Turkey - but also including Finland ${ }^{5}$ and Poland, that have voluntary private pension coverage of less than $10 \%$. These nations also have relatively high mandatory replacement rates for average earners (measured on a prospective basis). For these seven countries, the average gross replacement rate is $71 \%$ compared with $59 \%$ for the OECD as a whole. 
The second cluster consists of eight countries with much lower mandatory replacement rates. Unsurprisingly, half of this group are from the mainly English-speaking countries - Canada, Ireland, the United Kingdom and the United States. However, Belgium, the Czech Republic, Germany and Japan show a similar relationship between private pension coverage and the scale of the mandatory pension system. In these eight countries, the mandatory replacement rate for the average earner is just $38 \%$.

A number of governments - Germany, Ireland, New Zealand and the United Kingdom, for example - explicitly aim to increase the proportion of the workforce with voluntary private pensions. It is worth noting that voluntary private pension coverage does not reach much over $50 \%$ of the workforce. Mandating private pensions appears, from the international experience, the only way to have private-pension coverage at a level significantly above one half (Table II.2.1).

\section{Figure II.2.3. Average projected mandatory pension and coverage of voluntary private pensions}

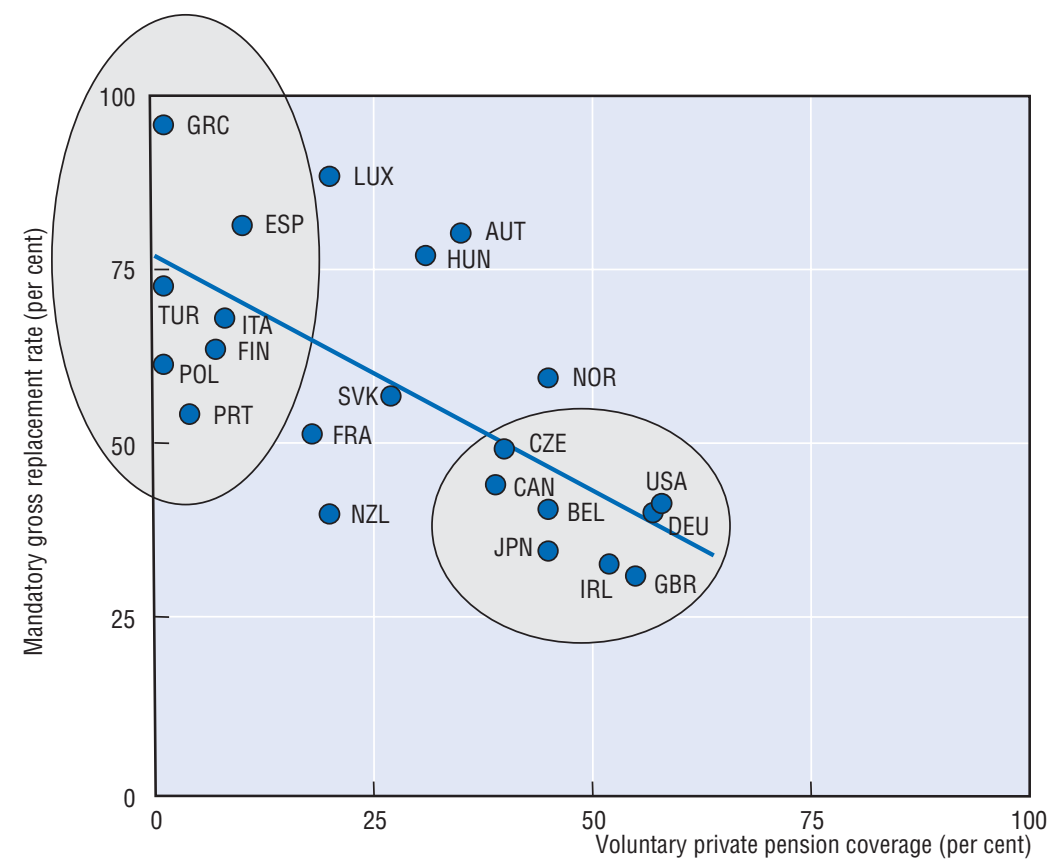

Note: Regression results are coverage $=67.8(10.6)-0.692(-.176) \times$ gross replacement rate (standard errors in parentheses). Both are significant at $1 \%$. The $\mathrm{R}^{2}$ is 0.434 . The two clusters marked are countries with high mandatory replacement rates and low coverage of private pensions and vice versa (see text).

Source: Coverage data from Table II.2.1 refer to occupational private pension schemes; gross replacement rates for average earners from OECD pension models.

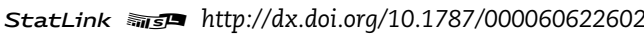

\subsection{Filling the retirement-savings gap}

In the 11 countries under study, the gross replacement rate for the average earner under the mandatory pension system averages $40.6 \%$ of earnings. Voluntary, private pension savings would need to provide an additional replacement rate of $18.1 \%$ to bring pensions in these countries up to the OECD average relative to individual earnings, as shown in Columns 1 and 2 of Table II.2.2. 
The lingering demise of DB occupational pension schemes means that new labourmarket entrants in these 11 countries will have access mainly or only to DC plans to close the retirement-savings gap. Table II.2.2 shows the steps required to calculate the contribution rate - the proportion of earnings paid into the defined-contribution account that would deliver the replacement rate required to equal the OECD average pension.

The 11 countries under study differ in the normal pension age, as shown in Column 3 of Table II.2.2. The normal pension age is age 65 in eight of the countries, but is 60 in France, 62 in Hungary and will reach 67 in the United States. The normal pension age affects the duration over which contributions are made. On the baseline assumption of labour-market entry at age 20, individuals will contribute for between 40 and 47 years, although in most cases this will be for a 45-year period, as shown in Column 4 of Table II.2.2. Column 5 shows the accumulated pension capital at the time of retirement for each unit of contributions and how this varies with the contribution period. With 45 years' contributions, the accumulated capital at retirement would be 64.3 times the annual contribution. The difference between the 45 units contributed and the 64.3 units of accumulated pension capital is because of the compound-interest effect. (The results in Table II.2.2 use the baseline assumptions of this report: $2 \%$ annual growth in real earnings and a $3.5 \%$ annual real return on investments.)

Normal pension ages - along with national life expectancy - also affect the duration over which the pension is likely to be paid. This is the role played by the "annuity factor" in these calculations. The annuity factor - Column 6 - gives the present value of a flow of pension payments, taking account of differences in pension age and life expectancy.

The final column of Table II.2.2 shows the percentage of earnings that an average earner would need to pay into a private pension plan to plug the retirement-savings gap. The results are also shown graphically in Figure II.2.4. The United Kingdom has the largest replacement-rate gap and the highest required contribution rate. Japan's replacement-rate gap is 4 percentage points lower than in the United Kingdom but life expectancy is longer, as evidenced by the higher annuity factor in Table II.2.2. The required contribution rate in Japan is $6.7 \%$ compared with $6.9 \%$ in the United Kingdom. France has the smallest replacement-rate gap, but normal retirement age of 60 and life expectancy above the OECD average together imply that the annuity factor is the highest in Table II.2.2. This, in turn, increases the required contribution rate compared with countries with normal retirement at 65 or more. The required contribution rate is $2.6 \%$ in France and the Czech Republic. 
Table II.2.2. Filling the retirement-savings gap

Calculating the required contribution rate

\begin{tabular}{lccccccc}
\hline & $(1)$ & $(2)$ & $(3)$ & $(4)$ & $(5)$ & $(6)$ & $(7)$ \\
\cline { 2 - 8 } & $\begin{array}{c}\text { Mandatory GRR } \\
(\%)\end{array}$ & $\begin{array}{c}\text { GRR gap } \\
(\%)\end{array}$ & Pension age & Years & Accumulation & $\begin{array}{c}\text { Annuity factor } \\
\text { Australia }\end{array}$ & $\begin{array}{c}\text { Contribution rate } \\
(\%)\end{array}$ \\
Belgium & 43.1 & 15.6 & 65 & 45 & 64.3 & 16.5 & 4.0 \\
Canada & 40.4 & 18.3 & 65 & 45 & 64.3 & 16.4 & 4.7 \\
Czech Republic & 43.9 & 14.8 & 65 & 45 & 64.3 & 16.4 & 3.8 \\
France & 49.1 & 9.6 & 63 & 43 & 60.4 & 16.6 & 2.6 \\
Germany & 51.2 & 7.5 & 60 & 40 & 54.8 & 19.3 & 2.6 \\
Ireland & 39.9 & 18.8 & 65 & 45 & 64.3 & 16.0 & 4.7 \\
Japan & 32.5 & 26.2 & 65 & 45 & 64.3 & 15.7 & 6.4 \\
New Zealand & 34.4 & 24.3 & 65 & 45 & 64.3 & 17.6 & 6.7 \\
United Kingdom & 39.7 & 19.0 & 65 & 45 & 64.3 & 16.2 & 4.8 \\
United States & 30.8 & 27.9 & 65 & 45 & 64.3 & 16.0 & 6.9 \\
\hline
\end{tabular}

Note: $\mathrm{GRR}=$ gross replacement rate. The calculations assume a real rate of return on investment of 3.5\% per year. A full career of contributions is defined as from age 20 to the normal pension eligibility age. Actuarial calculations use World Bank/United Nations mortality projections for 2040.

Source:

Replacement rates - Columns 1 and 2 - are taken from the OECD pension models. For information on normal pension eligibility ages, see the country chapters in this report.

Years of contributions - Column 4 - are simply the difference between normal pension eligibility age and age 20, the baseline assumption for labour-market entry.

The calculation of accumulated pension capital - Column 5 - is based on $K=e^{r T} \frac{e^{(g-r) T}-1}{g-r}$, where $\mathrm{K}$ is pension capital, $g$ is real earnings growth and $r$ is the real rate of return on investments and $T$ is the duration of contributions. The derivation of this formula is explained in Box 1 of Queisser and Whitehouse (2006).

The calculation of the annuity factor - Column 6 - is based on the survival function, $\mathrm{s}_{\mathrm{i}}$, which is defined as $\prod_{i=R}^{100}\left(1-\lambda_{i}\right)$, where $\Pi$ is the product operator and $\lambda$ is the mortality rate by age, indexed $i$, and $R$ is the retirement age. The annuity factor, A is then $\sum_{i=R}^{100} s_{i}(1+z)^{-i}$. See Box 2 of Queisser and Whitehouse (2006).

Source: The required contribution rate - Column 7 - is the replacement rate gap - Column 2 - divided by the capital accumulation - Column 5 - multiplied by the annuity factor - Column 6.

Figure II.2.4. Filling the retirement-savings gap

Contribution rate with a full history required for average earner to reach OECD average gross replacement rate

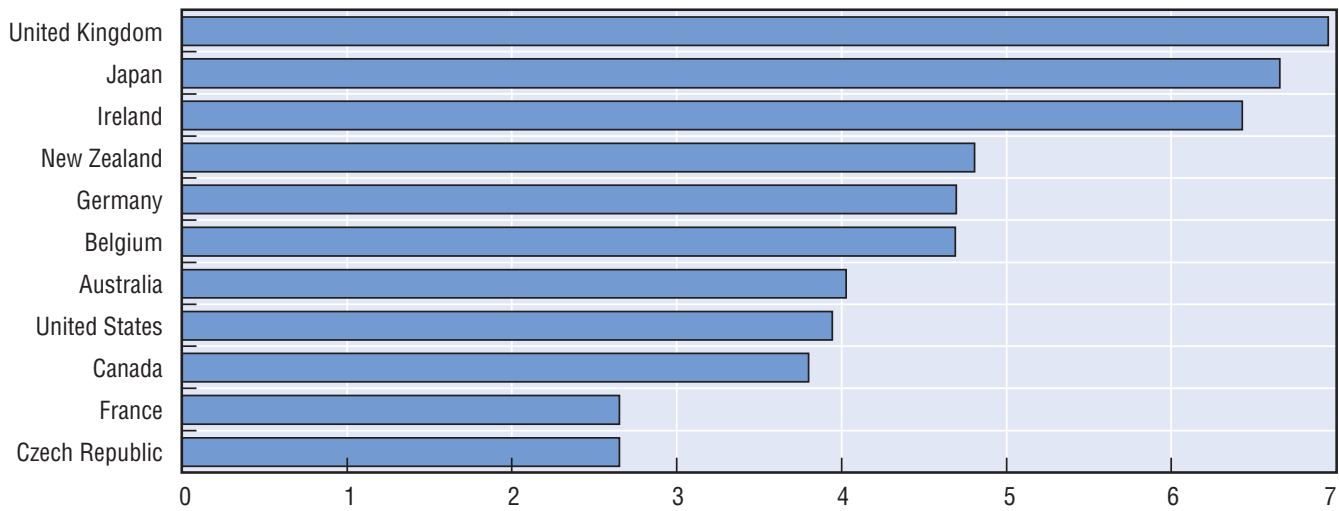

Source: OECD pension models; see Table II.2.2. 


\subsection{Contribution density and the retirement-savings gap}

The baseline assumption when Pensions at a Glance compares mandatory pension systems is that of a full-career worker, defined as a worker who enters the labour market at age 20 and contributes every year until the normal pension age in the respective country. The reasoning behind this assumption is set out above in the methodology section. However, people can usually choose whether or not to be covered by voluntary schemes and how much to contribute. In contrast, mandatory pension systems cover workers whether they like it or not. Secondly, they do not offer a choice of how much to contribute. Thirdly, through systems of credits for childcare and unemployment, they also often cover people when they are not working. A full career of contributions is therefore less realistic as a baseline for voluntary, private pensions than it is for mandatory schemes.

Figure II.2.5 shows how the number of years over which people contribute affects the contribution rate required to fill the retirement-savings gap, that is, to deliver an overall mandatory plus voluntary - replacement rate that equals the OECD average mandatory replacement rate. At the left-hand side of the chart is the required contribution rate with a full contribution history - from age 20 to national normal pension age - which reprises the results in Table II.2.2 and Figure II.2.4 above.

The next entry on the chart shows the situation with five years missing from the contribution history, i.e., assuming people delay starting their private pension until age $25{ }^{6}$ With ten missing years - at the centre of the chart - the required contribution rate in the United Kingdom increases to nearly 10\%, compared with $7 \%$ with a full career. With 20 missing years, contributions need to be nearly $15 \%$ to plug the retirement-savings gap. In Ireland and Japan, the necessary contribution rates are a little below the rates for the United Kingdom.

In Belgium, Germany and New Zealand, the required contribution rate is around $4.6 \%$ for a full career, $6.7 \%$ with ten missing years and $10 \%$ with 20 missing years.

\section{Figure II.2.5. Contribution density and the retirement-savings gap}

Contribution rate needed to reach OECD average gross replacement rate by number of years of contributions

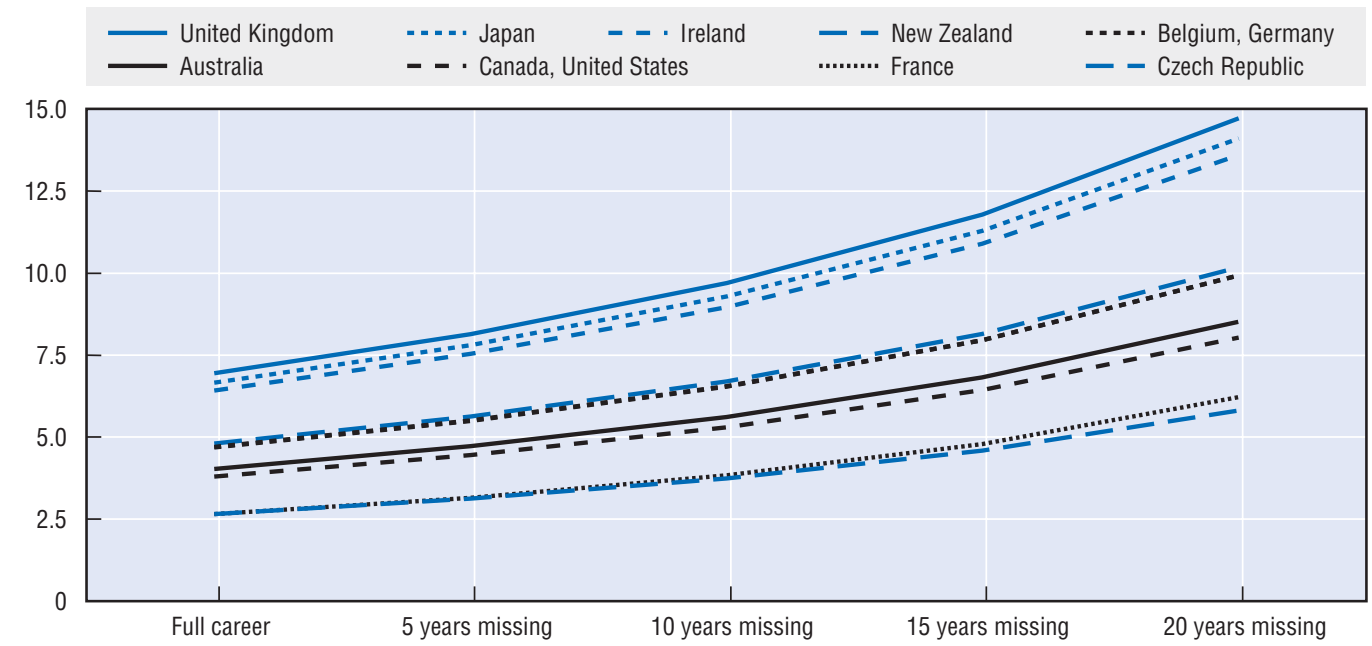

Note: Missing years are assumed to occur at the beginning of the career.

Source: OECD pension models. For details, see notes to Table II.2.2.

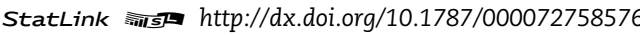




\subsection{Real rates of return on investments and the retirement-savings gap}

The value of DC pensions during retirement depends crucially on the rate of return on investments as well as on the amount contributed. Figure II.2.6 shows how varying the real rate of return affects the contribution rate required to fill the retirement-savings gap relative to the baseline assumption of this report, which is a $3.5 \%$ real return.

What matters for the replacement rate with a DC pension is the differential between the real return on investments and real wage growth. The analysis underlying Figure II.2.6 holds the assumed rate of wage growth constant at $2 \%$. It then looks at a situation with lower investment returns of $2 \%$, that is, equal to real wage growth. It also considers a higher investment return of $5 \%$. These low- and high-return scenarios are symmetric around the baseline.

Ireland, Japan and the United Kingdom have the largest retirement-savings gaps, averaging $6.7 \%$ on the baseline assumptions. However, a lower rate of return would naturally mean that individuals would need to contribute more. To fill the retirement savings gap in these three countries would need a 9.5\% contribution rate if real returns were only $2 \%$. In contrast, higher returns would offset some of the requirement to contribute to the private pension plan, lowering the necessary contribution rate to only $4.5 \%$.

At the other end of the scale, the contribution rates required in the Czech Republic and France would be $3.7 \%$ with low returns, $2.6 \%$ at the baseline and $1.8 \%$ with high returns.

Figure II.2.6. Rate of return on investments and the retirement-savings gap Contribution rate needed to reach OECD average gross replacement rate by rate of return on investments

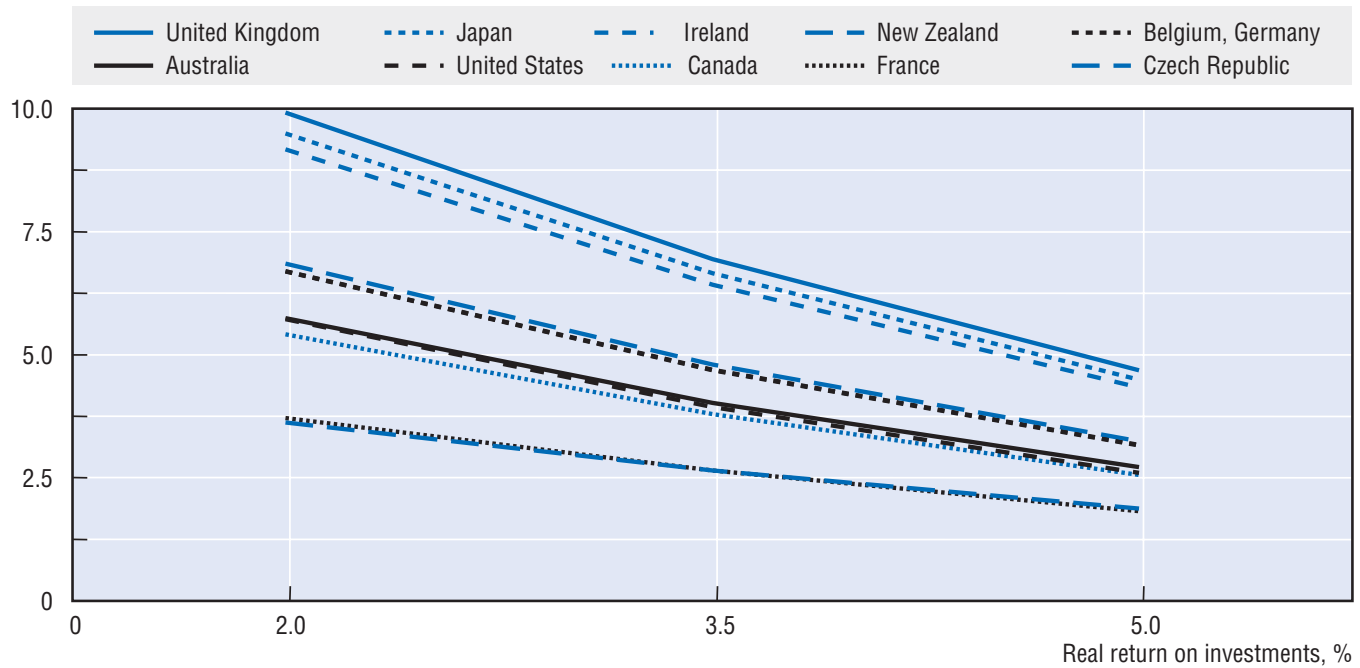

Source: OECD pension models. For details, see notes to Table II.2.2.

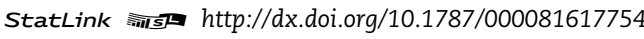

\subsection{Indicative gross replacement rates including voluntary pensions}

With assumptions of how long people contribute to voluntary private pensions and how much they contribute, the OECD pension models can calculate the overall replacement rate from both mandatory and voluntary pensions. Of the 11 countries that have been the focus of this chapter, there are data available on coverage of voluntary pensions for all bar Australia (Table II.2.1). Coverage in France and New Zealand is 20\% or less and so these plans are less likely to play an important role in providing retirement 
incomes in the future. In Japan, $\mathrm{DB}$, lump-sum and hybrid pension schemes remain the norm; DC plans have made few inroads.

Data on average contribution rates are even more difficult to obtain than information on coverage. The preliminary evidence presented in Table II.2.1 showed, for example, mean contribution rates for those covered of $8.5 \%$ in Canada, around $9 \%$ in the United Kingdom and United States and 10\% in Ireland. The average contribution in the Czech Republic is reported as $2.8 \%$. Reliable data are even harder to obtain for Belgium and Germany. A $4 \%$ contribution rate is assumed for Germany, since this is the maximum that attracts sizeable public subsidy. The results below assume a contribution rate of $4.25 \%$ for Belgium, which is at the upper end of the 1-5\% range that is thought to be typical (Table II.2.1). The contribution rates assumed in the analysis of voluntary private pensions are summarised in the final column of Table II.2.3.

The first column of Table II.2.3 reprises the mandatory gross replacement rates for average earners in the seven countries studied. These replacement rates vary from $31 \%$ in the United Kingdom to $49 \%$ in the Czech Republic, compared with the 59\% average for the OECD as a whole.

The following columns of Table II.2.3 show total replacement rates, including voluntary private pensions. These are shown for a full career of contributions (from 20 to the national normal pension age) and for contribution histories missing 10 and 20 years. The highest assumed contribution rate is in Ireland: $10 \%$ of earnings. Contributing for a full career would increase the gross replacement rate from $32.5 \%$ to $73.3 \%$, well above the OECD average. Even with ten missing years - i.e., contributions from age 30 to 65 - the total, mandatory plus voluntary replacement rate would be $61.7 \%$. Only with 20 missing years does the total replacement rate fall below the OECD average.

Table II.2.3. Indicative replacement rates for average earners

Mandatory pensions plus voluntary private pension schemes

\begin{tabular}{|c|c|c|c|c|c|}
\hline & \multicolumn{4}{|c|}{ Replacement rate for average earner (percentage) } & \multirow{3}{*}{$\begin{array}{c}\text { Assumed } \\
\text { contribution rate }\end{array}$} \\
\hline & \multirow{2}{*}{ Mandatory only } & \multicolumn{3}{|c|}{ Voluntary } & \\
\hline & & Missing 20 & Missing 10 & Full career & \\
\hline Belgium & 40.4 & 48.3 & 52.3 & 57.1 & $4.25 \%$ \\
\hline Canada & 43.9 & 55.0 & 63.2 & 72.6 & $8.5 \%$ \\
\hline Czech Republic & 49.1 & 53.7 & 56.3 & 59.3 & $2.8 \%$ \\
\hline Germany & 39.9 & 47.5 & 51.4 & 56.0 & $4 \%$ \\
\hline Ireland & 32.5 & 51.8 & 61.7 & 73.3 & $10 \%$ \\
\hline United Kingdom & 30.8 & 47.9 & 56.8 & 67.0 & $9 \%$ \\
\hline United States & 41.2 & 60.7 & 70.2 & 81.2 & $9 \%$ \\
\hline
\end{tabular}

Note: The results for the United Kingdom assume that the individual is contracted in to the public pension scheme (formerly Serps - the state earnings-related pension schemes -, now S2P - state second pension). If individuals were contracted out, the overall replacement rate would be lower because S2P benefits would be foregone in return for the rebate of social security contributions paid for contracting out.

Source: OECD pension models.

Figure II.2.7 shows how indicative replacement rates with voluntary pension schemes compare with the mandatory replacement rates in the rest of the OECD countries. The black line in this chart simply repeats the data from Figure II.2.2 in this chapter. With a full career of voluntary contributions, shown by the light-grey bars, total replacement rates compare favourably with those in countries with larger mandatory pension provision. Even 
with ten years' contributions missing, overall replacement rates are only significantly below the OECD average in Belgium and Germany, where the assumed contribution rate is smaller than in the other five countries studied. In Germany, however, voluntary pensions fill the gap between pre- and post-reform replacement rates.

\section{Figure II.2.7. Indicative replacement rates for average earners: mandatory and voluntary schemes}

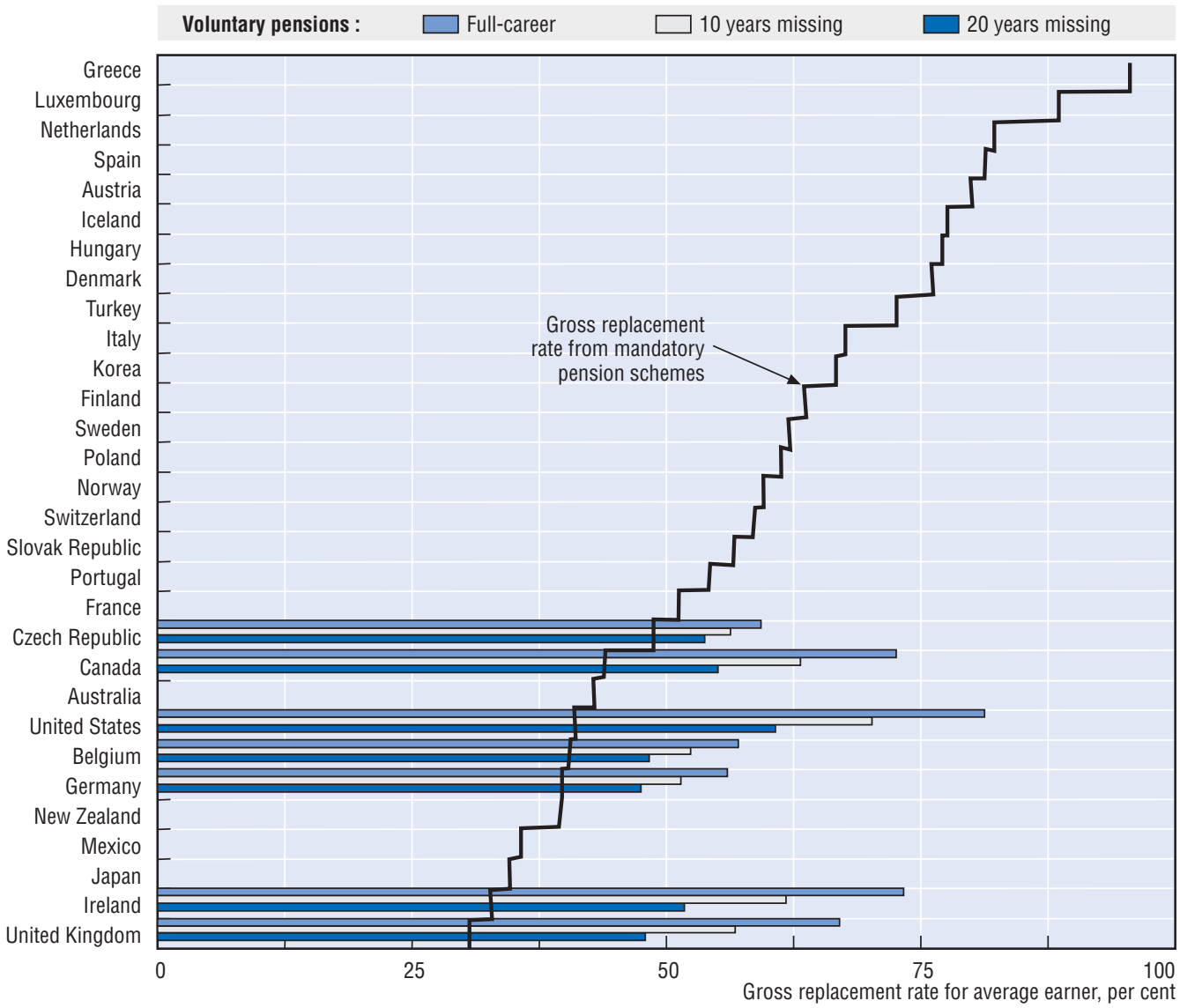

Source: OECD pension models.

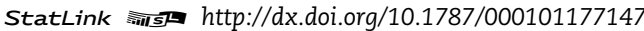

\subsection{Conclusions and future developments}

The target replacement rate from the mandatory (usually public) pension system is relatively low, leaving a large "space" for voluntary, private pension provision in around a dozen OECD countries. In most of these countries, coverage of private pensions is broad. Around one half of employees contribute to private pensions (on the best available evidence). However, this leaves a substantial potential gap in private-pension coverage. In many cases, this may simply result from the fact that the need for retirement savings is concentrated among either high- or high- and middle-earners. If low earners can expect an adequate retirement income from safety-net provisions, there might be no need for them to save for old age. But this is by no means certain.

A second concern arises because the coverage data are a "snapshot" whereas lifetime coverage and contributions determine individual's retirement incomes. It is not possible, 
for example, to know whether snapshot coverage of 50\% implies that half the workforce contributes for every year of their working lives or the whole workforce contributes for half of their working lives. The implications for pension policy are very different if the target is to get more people to contribute or to get the same people to contribute for more of their careers.

The "traditional" way of encouraging voluntary savings for retirement has been through tax incentives. However, these can be expensive and there is strong evidence that they are inefficient, in that much of the saving would have happened anyway without the incentive; tax incentives tend to be worth more to higher earners, for example.

New approaches to encouraging private pension saving rely on the insights of behavioural economics about people's natural inertia. Such "soft compulsion", requiring people to save unless they opt out, will be introduced at a national level, first, with the KiwiSaver plan in New Zealand. The United Kingdom aims to introduce a similar scheme and Ireland is debating the merits of going down this route in an attempt to raise privatepension coverage to $70 \%$.

The OECD will continue to monitor these innovations in pension policy in future editions of Pensions at a Glance and assess their implications for pension policy throughout its member countries.

\section{Notes}

1. See Mattil and Whitehouse (2007) and Whitehouse et al. (2007) on these reforms.

2. Gustman and Steinmeier (1992) and Disney and Whitehouse (1992) call the change in the United States and United Kingdom, respectively, a "stampede".

3. However, the Annex to this chapter presents some data on DB plans.

4. In Mexico, a large informal sector means that many workers are not covered by the mandatory pension system. Moreover, the new pension scheme, based around mandatory individual accounts, guaranteed all workers in the labour market at the time of reform that their pensions would not fall below those promised by the old pension system. Thus, the issue of the retirementsavings gap in Mexico has a very different character from that in other OECD countries.

5. There are nine earnings-related pension programmes for different occupations in Finland, four of which cover private sector employees. All schemes have harmonised rules, are co-ordinated by the Central Pension Security Institute and are counted as part of general government.

6. Compounding of interest over time means that missing contributions earlier in the career matters more for the replacement rate than in later years (provided that the investment return exceeds wage growth, which is the baseline assumption of this report). 


\section{ANNEX \\ Gross Replacement Rates Including Defined-Benefit Occupational Plans}

Section 2.2 of this chapter showed how DB occupational schemes, particularly for workers in the private sector, are being replaced by DC plans. This change affects workers in more than half of countries with significant coverage of voluntary, employer-provided pensions.

The first edition of Pensions at a Glance showed calculations for replacement rates including DB occupational plans for three countries: Canada, the United Kingdom and the United States. This Annex provides updated information for these three countries along with information for Ireland.

Table II.A2.1 briefly summarises the main parameters of the DB schemes that have been modelled. In most cases, national surveys of pension plan parameters and rules have formed the basis for choosing these particular values although there is, of course, considerable variation between different schemes.

Table II.A2.1. Parameters and rules of illustrative defined-benefit occupational plans

\begin{tabular}{lllll}
\hline & Canada & Ireland & United Kingdom & United States \\
\hline Earnings measure & Final salary & Final salary & Final salary & Final salary \\
Accrual rate & $2 \%$ & $1.67 \%$ & $1.25 \%$ & $1.5 \%$ \\
Integration & Lower accrual & Basic pension & Contracted out & - \\
Preservation & None & Price inflation & Price inflation & None \\
Indexation & Half price inflation & Price inflation & Price inflation & None \\
\hline
\end{tabular}

Note: Integration in Canada means that the accrual rate is $1.3 \%$ on earnings to the ceiling of the public pension and $2 \%$ above. In Ireland, only earnings above the basic pension are assumed to accrue DB pensions. The occupational plan in the United Kingdom is assumed to be contracted out of the state earnings-related pension scheme/state second pension (Serps/S2P), implying that the individual foregoes these benefits. The parameters shown for the United Kingdom are the minimum benefits that allow contracting out. The row entitled "Preservation" shows the rules for adjusting benefits for early leavers who change job before retiring.

Source: OECD Secretariat based on OECD (1995a), National Association of Pension Funds (2005), Government Actuary's Department (2006), Mitchell and Dykes (2000).

Table II.A2.2 provides indicative replacement rates split by component of the pension system. In all cases, the worker is assumed to spend a full career covered by an occupational pension plan. However, it is assumed that the career is divided into four equally long jobs. Changing employer reduces the value of the pension because of incomplete preservation of final-salary-based rights between the time of changing job and retiring. 
In Canada, a worker on average earnings with an occupational plan would, under these assumptions, have an extra $26 \%$ replacement rate on top of the public pension scheme. However, part of this would be offset by reduced entitlement to the targeted scheme, the guaranteed income supplement.

The results for the United Kingdom are complicated by the rules for contracting out of the state pension. The individual will lose a $15.6 \%$ replacement rate from the state second pension while gaining $37.4 \%$ from the occupational plan. The occupational plan in Ireland delivers a much lower replacement rate than in the United Kingdom because of the integration of the benefit with the public scheme, meaning that only earnings above the basic pension are covered.

Table II.A2.2. Indicative replacement rates for average earners

Mandatory pensions plus voluntary defined-benefit occupational schemes

\begin{tabular}{lccccc}
\hline & Targeted & Basic & Public & Occupational & Total \\
\hline Canada & 4.6 & 14.4 & 25.0 & & $\mathbf{4 3 . 9}$ \\
Ireland & 0.0 & 14.4 & 25.0 & 26.4 & $\mathbf{6 5 . 8}$ \\
& & 32.5 & & & $\mathbf{3 2 . 5}$ \\
United Kingdom & 32.5 & 15.6 & & $\mathbf{4 9 . 9}$ \\
& & 15.2 & & 37.4 & $\mathbf{3 0 . 8}$ \\
United States & 15.2 & 41.2 & & $\mathbf{5 2 . 6}$ \\
& & & 41.2 & 30.6 & $\mathbf{4 1 . 2}$ \\
\hline
\end{tabular}

Note: Assumes that the occupational pension in the United Kingdom is contracted out of the state pension scheme. Source: OECD pension models. See also OECD (2005), Part II, "Voluntary, Occupational Pensions". 


\section{References}

Brown, R.L. and J. McDaid (2002), "Factors Affecting Retirement Mortality", North American Actuarial Journal, Vol. 7, No. 2, pp. 24-43.

Copeland, C. (2006), "Retirement Plan Participation and Retirees' Perception of their Standard of Living”, Issue Brief No. 289, Employee Benefits Research Institute, Washington DC.

Dang, T.T., P. Antolín and H. Oxley (2001), "Fiscal Implications of Ageing: Projections of Age-Related Spending”, Working Paper No. 305, Economics Department, OECD, Paris.

Department of Labor, Employee Benefits Security Administration (various years), Private Pension Plan Bulletin: Abstract of Form 5500 Annual Reports, Washington, DC.

Department of Work and Pensions (2006a), Second Tier Pension Provision 1978/79 to 2003/04, London.

Department of Work and Pensions (2006b), The Abstract of Statistics for Benefits, National Insurance Contributions and Indices of Prices and Earnings: 2005 edition, London.

Disney, R.F. and E.R. Whitehouse (1992), The Personal Pension Stampede, Report No. 42, Institute for Fiscal Studies, London.

European Union, Economic Policy Committee (2005), "The 2005 Projections of Age-Related Expenditure (2004-2050) for the EU-25 Member States: Underlying Assumptions and Projection Methodologies", European Economy, Special Report No. 4/2005.

European Union, Economic Policy Committee (2006), “The Impact of Ageing on Public Expenditure: Projections for the EU-25 Member States on Pensions, Health Care, Long-term Care, Education and Unemployment Transfers (2004-2050)", European Economy, Special Reports No. 1/2006.

European Union, Social Protection Committee (2005), Privately Managed Pension Provision, Brussels.

Fujisawa, R. and E.R. Whitehouse (2007), “The Role of the Tax System in Old-Age Support: CrossCountry Evidence", Social, Employment and Migration Working Paper, OECD, Paris, forthcoming.

Government Actuary's Department (2005), Occupational Pension Schemes 2004: Twelfth Survey by the Government Actuary, London.

Government Actuary's Department (2006), Occupational Pension Schemes 2005: Thirteenth Survey by the Government Actuary, London.

Gustman, A. and T. Steinmeier (1992), "The Stampede towards Defined Contribution Plans: Fact or Fiction?”, Industrial Relations, Vol. 31, pp. 361-369.

Mattil, B. and E.R. Whitehouse (2007), "Individual Incentives to Switch between Public and Private Pension Schemes", Social, Employment and Migration Working Paper, OECD, Paris, forthcoming.

McHale, J. (1999), “The Risk of Social Security Benefit Rule Changes: Some International Evidence”, Working Paper No. 7031, National Bureau of Economic Research, Cambridge, Mass.

Mitchell, O.S. and E.L. Dykes (2000), "New Trends in Pension Benefit and Retirement Provisions", Working Paper No. 2000-01, Pension Research Council, Wharton School, University of Pennsylvania, Philadelphia.

Morissette, R. and A. Johnson (2003), “Are Good Jobs Disappearing in Canada?”, Research Paper No. 239, Analytical Studies Branch, Statistics Canada, Ottawa.

National Association of Pension Funds (2005), Annual Survey, London.

OECD (1995a), Private Pensions in OECD Countries: Canada, Paris.

OECD (1995b), The Tax/Benefit Position of Production Workers: 1991-1994, Paris. 
OECD (2001), Taxing Wages: Income Tax, Social Security Contributions and Cash Family Benefits 1999-2000, Paris.

OECD (2004), OECD Classification and Glossary of Private Pensions, Paris.

OECD (2005), Pensions at a Glance: Public Policies across OECD Countries, Paris.

OECD (2006a), Taxing Wages, Paris.

OECD (2006b), Live Longer, Work Longer, Paris.

OECD (2007), Benefits and Work Incentives, Paris.

Palacios, R.J. (2002), "Managing Public Pension Reserves Part II: Lessons from Five Recent OECD Initiatives", Pension Reform Primer series, Social Protection Discussion Paper No. 0219, World Bank, Washington, DC.

Palacios, R.J. and M. Pallares-Miralles (2000), "International Patterns of Pension Provision", Pension Reform Primer series, Social Protection Discussion Paper No. 0009, World Bank, Washington, DC.

Pensions Board (various years), Annual Report, Dublin.

Queisser, M. and E.R. Whitehouse (2006), "Neutral or Fair? Actuarial Concepts and Pension-System Design", Social, Employment and Migration Working Paper No. 40, OECD, Paris.

Salomaki, A. (2006), "Public Pension Expenditure in the EPC and the European Commission Projections: An Analysis of the Projection Results", European Economy Economic Papers No. 268, European Commission, Brussels.

Schembari, P. (2004), "Pension Plans in Canada", Pension and Wealth Research Paper No. 1, Statistics Canada, Ottawa.

Whiteford, P. and E.R. Whitehouse (2006), "Pension Challenges and Pension Reforms in OECD Countries", Oxford Review of Economic Policy, Vol. 22, No. 1, pp. 78-94.

Whitehouse, E.R. (2000), "Administrative Charges for Funded Pensions: Measurement Concepts, International Comparison and Assessment”, Journal of Applied Social Science Studies, Vol. 120, No. 3, pp. 311-361.

Whitehouse, E.R. (2001), “Administrative Charges for Funded Pensions: Comparison and Assessment of 13 Countries", Private Pension Systems: Administrative Costs and Reforms, Private Pensions Series, Vol. 3, OECD, Paris.

Whitehouse, E.R. (2006), Pensions Panorama: Retirement-Income Systems in 53 Countries, World Bank, Washington, DC.

Whitehouse, E.R. (2007a), “Pension Incentives to Retire”, Social, Employment and Migration Working Paper, OECD, Paris, forthcoming.

Whitehouse, E.R. (2007b), "Life-Expectancy Risk and Pensions: Who Bears the Burden?", Social, Employment and Migration Working Paper, OECD, Paris, forthcoming.

Whitehouse, E.R., B. Mattil and R.J. Palacios (2007), “Rebalancing Retirement-Income Systems: The Role of Individual Choice under Mixed Public/Private Pension Provision", Fiscal Studies, forthcoming. 



\section{PART III}

\section{Country Studies}

This part provides detailed background information on each of the 30 countries' retirement-income arrangements. These include FFpension eligibility ages and other qualifying conditions; the rules for calculating benefit entitlements; the treatment of early and late retirees; and more detailed information on the pre-reform scenarios explored in the special chapter on pension reforms in Part II. The country studies summarise the national results in standard charts and tables. 



\section{Introduction}

$\mathrm{T}$ he country studies follow a standard schema. First, there is a detailed description of the rules and parameters of the pension schemes:*

- Qualifying conditions: pension eligibility (or "retirement") age and years of contributions required to receive a pension.

- Benefit calculation: the rules for each of the schemes making up the pension system, such as earnings-related schemes, mandatory private plans and resource-tested schemes.

- Early and late retirement: the rules and conditions under which workers can retire early or continue to work beyond the standard retirement age. (This extends the information provided in the first edition of Pensions at a Glance.)

- Pre-reform scenario: for those countries that had major pension reforms or a series of smaller reforms since the 1990s, this section explains the parameters and rules chosen to represent the pre-reform scenario, as discussed in the special chapter on pension reforms.

The treatment of pensioners under the personal income tax and social security contributions, for reasons of space, is not described in this edition. For details on the tax rules and social security contributions that apply to retirees in the respective countries, see the first edition of Pensions at a Glance (OECD, 2005) and Fujisawa and Whitehouse (2007). For information on the tax treatment of workers, see Taxing Wages (OECD, 2006).

Values of all pension parameters and other relevant figures, such as minimum wages, are given in national currencies and as a proportion of average earnings. (See Table 0.1 for values and the surrounding text for a discussion of recent changes to the way the OECD calculates average earnings.)

A summary results table gives expected relative pension values, replacement rates and pension wealth at different individual levels of earnings for mandatory pension schemes. (See Part I of this report for definition and measurement of the different indicators.) These are given in both gross and net terms (the latter taking account of taxes and contributions paid when working and when drawing the pension). For countries that had major pension reforms, a second table shows the same set of indicators under the prereform scenario (see the special chapter on pension reforms for more details).

Summary charts show the breakdown of the gross relative pension value into the different components of the pension scheme (the first row of the charts). As far as possible, the same terminology is used to describe these schemes. The particular national scheme

\footnotetext{
* Note that the modelling relates to single, full-career workers drawing the pension from the normal eligibility age. Systems can have complex rules for periods out of the labour market (caring for children or in unemployment, for example) or treat married couples as a single unit. These rules do not affect the modelling results presented here.
} 
that is described can be found in the text of the country study. Some standard abbreviations are used in the legends of the charts:

- SA: social assistance.

- Targeted: separate resource-tested schemes for older people.

- Minimum: a minimum pension within an earnings related scheme.

- Basic: a pension based only on number of years of coverage or residency.

- Earnings-related: all public earnings-related programmes, including notional accounts and points schemes as well as traditional defined-benefit plans.

- DC: defined-contribution, mandatory private plans.

- Occupational: mandatory pensions, which can be provided by employers, industry-wide schemes (Netherlands), profession-based schemes (Sweden) or publicly (Finland, France).

The second row of country charts shows the effect of personal income taxes and social security contributions on relative pension values and replacement rates, giving the gross and net values.

The charts use a standard scale to ease comparisons between countries: the scale for replacement rates runs to $125 \%$ while that for relative pension values runs to 2.5 times average earnings. In some cases, pension benefits exceed these maxima and so the measure has been capped at these levels. 


\section{Australia}

A

ustralia's pension system has two components: a means-tested age pension plus the superannuation guarantee, a compulsory contribution to a private pension plan. These plans are mainly defined contribution.

\section{Qualifying conditions}

The age pension is payable from age 65 for men. Women's pensionable age - currently $62 \frac{1}{2} 2$ - will increase gradually to become 65 by 2014 . The minimum age for withdrawing superannuation guarantee benefits is currently 55 , but this will increase gradually to 60 by 2025 .

\section{Benefit calculation}

\section{Defined contribution}

The superannuation guarantee was introduced in 1992. It consists of a mandatory employer contribution to a private pension plan. The pension plans may be operated by the employer, industry associations, and financial service companies or even by individuals themselves. The mandatory contribution rate has been 9\% since the 2002-03 tax year.

Employers need not contribute for workers earning less than AUD 450 in a month (equivalent to AUD 5400 a year), but they can choose to contribute for these workers. (Note that this minimum has not been raised in the past.) There is also a limit to the earnings covered by the superannuation guarantee: employers need not contribute for employees' pay above this threshold. For each quarter of the financial year 2003-04, this amount is AUD 30560 and for each quarter of the year 2004-05, it is AUD 32 180. This limit is worth around $2 \frac{1}{2}$ times average wages and is indexed to a measure of average earnings.

The withdrawal stage of the superannuation guarantee complicates the calculations. Although there are some defined-benefit occupational plans, most employees are members of defined-contribution schemes. Members can take out the accumulated capital as a lump sum or some sort of income stream. Currently, most benefits are taken as a lump sum. For comparison with other countries (where defined-benefit plans predominate), the capital from the superannuation guarantee is converted to a price-indexed annuity. The annuity calculation is based on mortality data for Australia.

\section{Targeted}

The value of the age pension is adjusted biannually and it is paid fortnightly. In September 2003, the maximum single rate of pension was AUD 453 a fortnight, increasing to AUD 464 in March 2004 and AUD 471 in September 2004. (All values have been rounded to the nearest dollar.) This gives an average for the tax year of an annual benefit of AUD 12 241, equivalent to a quarter of average earnings.

The age pension is withdrawn once annual income from other sources exceeds a threshold known as the "free area". This is adjusted annually in July. The values for 2004 were AUD 120 in the first half and AUD 122 in the second half of the year (again calculated fortnightly). The tax year figure for 2004 was therefore AUD 3 172, or $6.5 \%$ of average earnings. The withdrawal rate is $40 \%$. There is also an assets test. However, over $90 \%$ of pensioners affected have their benefits reduced by the income rather than the assets test 
(and so it has been assumed in the modelling that the income test is binding). Around a third of pensioners have their benefit reduced by the means test, and are therefore on partrate age pension. Two-thirds of pensioners are on the maximum age pension.

The age pension's value is increased in line with prices, but where necessary a further increase is made to ensure that it does not fall below $25 \%$ of the average of pre-tax male total weekly earnings on the national definition (which is slightly different from the earnings measure used in OECD analysis).

\section{Early retirement}

Access to superannuation benefits (including superannuation guarantee benefits) is currently possible on retirement on or after age 55 (increasing to age 60). There is no early retirement under the age pension.

\section{Late retirement}

It is possible to defer claiming superannuation after 65. Employers are required to make superannuation contributions under the superannuation guarantee arrangements for their eligible employees up to the age of 70 .

It is also possible to defer claiming the age pension after 65 . The pension bonus scheme pays a once-only, tax-free lump sum to eligible members who defer claiming age pension and continue to work. The bonus is paid when the eligible member claims and receives age pension. A person must register and work a minimum of 12 months from date of registration, and must complete at least 960 hours of gainful work each year. The bonus can be accrued for up to five years. The amount of bonus is 9.4 per cent of the basic age pension entitlement for the first year of deferral. For two years, the bonus is four times that amount, nine times for three years, 16 times for four years and 25 times for five years. The maximum, five-year bonus is equivalent to 2.35 times one year's maximum age pension entitlement. 


\section{Pension modelling results: Australia}

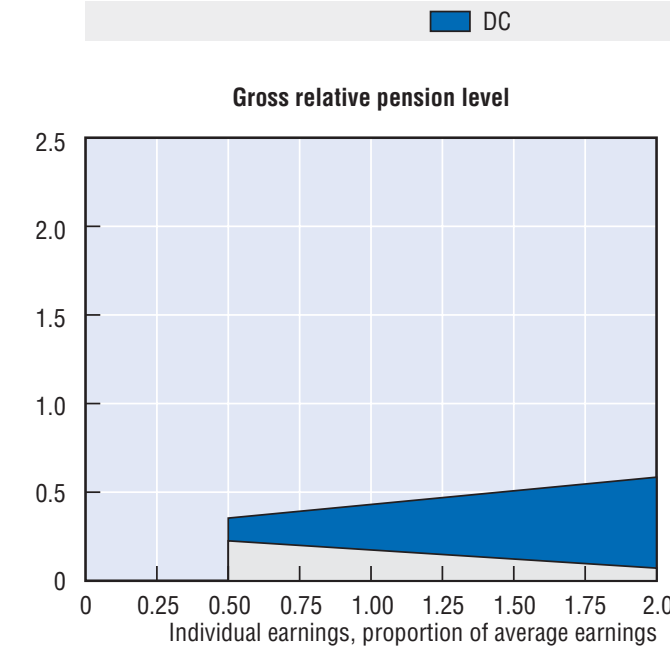

Targeted
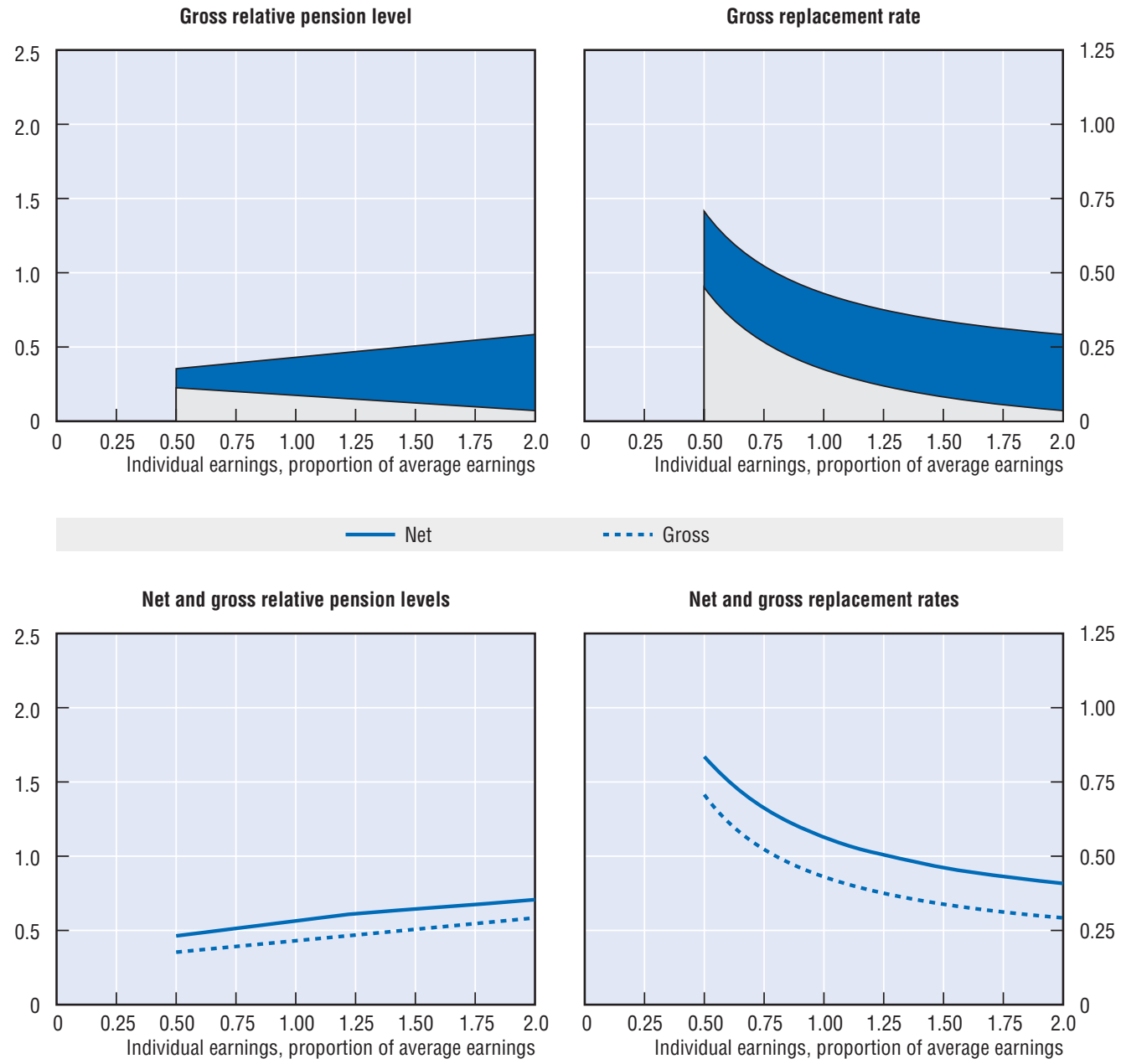

\begin{tabular}{|c|c|c|c|c|c|c|}
\hline \multirow{2}{*}{$\begin{array}{l}\text { Men } \\
\text { Women (where different) }\end{array}$} & \multirow{2}{*}{$\begin{array}{l}\text { Median } \\
\text { earner }\end{array}$} & \multicolumn{5}{|c|}{ Individual earnings, multiple of economy-wide average } \\
\hline & & 0.5 & 0.75 & 1 & 1.5 & 2 \\
\hline Gross relative pension level & 40.8 & 35.4 & 39.2 & 43.1 & 50.8 & 58.5 \\
\hline \multicolumn{7}{|l|}{ (\% average gross earnings) } \\
\hline Net relative pension level & 53.4 & 46.3 & 51.4 & 56.4 & 64.4 & 70.7 \\
\hline \multicolumn{7}{|l|}{ (\% net average earnings) } \\
\hline Gross replacement rate & 47.9 & 70.7 & 52.3 & 43.1 & 33.8 & 29.2 \\
\hline \multicolumn{7}{|l|}{ (\% individual gross earnings) } \\
\hline Net replacement rate & 61.7 & 83.5 & 66.2 & 56.4 & 46.1 & 40.8 \\
\hline \multicolumn{7}{|l|}{ (\% individual net earnings) } \\
\hline Gross pension wealth & 8.2 & 12.5 & 9.0 & 7.3 & 5.5 & 4.6 \\
\hline (multiple of individual gross earnings) & 9.5 & 14.6 & 10.5 & 8.4 & 6.4 & 5.4 \\
\hline Net pension wealth & 8.2 & 12.5 & 9.0 & 7.3 & 5.3 & 4.3 \\
\hline (multiple of individual gross earnings) & 9.5 & 14.6 & 10.5 & 8.4 & 6.2 & 5.0 \\
\hline
\end{tabular}




\section{Austria}

$\mathrm{T}_{\mathrm{s}}$

he pension system consists of a defined-benefit public scheme with an income-tested top-up for low-income pensioners.

\section{Qualifying conditions}

Normal pension age is 65 for men. For women, retirement age is currently 60 years but will be increased to 65 by 2033. There is a coverage condition: 180 months (15 years) in the last 30 years or 300 months (25 years) during the full lifetime. Alternatively, 180 months of contributions actually paid (as opposed to coverage alone) are sufficient. Insured months are either contributory months (from employment or voluntary contributions) or supplementary (i.e., credited months, known as Ersatzzeiten) for which only limited contributions are paid.

\section{Benefit calculation}

\section{Earnings-related}

The pension benefit currently accrues at $1.96 \%$ (2006: 1.88\%) of earnings for each year of contributions but this will fall gradually, reaching $1.78 \%$ by 2009 .

The averaging period for calculating benefits is being extended: from a smaller number of best years' earnings, it will reach 40 years from 2028. The valorisation procedure is complex although in practice adjustments have been closer to price inflation than to earnings growth. Valorisation under this new procedure is still under discussion. The modelling takes this full-career measure and assumes that earlier years' earnings are revalued in line with earnings growth.

Contributions are payable up to a ceiling of EUR 48300 a year, corresponding to $147 \%$ of average earnings.

In 2005, pensions in payment were adjusted in line with prices up to the median pension; pensions above this threshold were increased by a flat amount, which was equal to the absolute increase given to the median pensioner. From 2006 to 2009, it is envisaged that pensions will be fully indexed to prices up to 15 times the daily contribution ceiling which for 2004 would have been EUR $115 \times 15=1725$. The modelling assumes that this practice will continue.

\section{Targeted}

There is a means-tested top-up (Ausgleichszulage) that ensures a minimum retirement income of EUR 653 per month for single people and EUR 1015 for a couple. There are fourteen annual payments. Again, adjustment of the safety-net income is discretionary; the modelling implicitly assumes that it will rise in line with average earnings.

\section{Early retirement}

Retirement is currently possible from 62 for men and from 60 for women, subject to 37.5 years of contributions or credits. From 2017 on, the earliest retirement age for women will also be 62. Pensions taken before the age of 65 are reduced by $4.2 \%$ for each year that the pension is claimed early. 


\section{Late retirement}

For retirement between the ages of 65 and 68 the pension is increased by $4.2 \%$ per year and there is no such increment after 68 . Workers who defer their pension continue to pay contributions thereby increasing their pension entitlements.

Combining work and pensions is possible but there is an earnings limit. If pensioners below the age of 65 earn more than EUR 323.46 (2005 value), the pension is fully withdrawn. After age 65, unlimited earnings from work and pension receipt are permitted.

\section{Pre-reform scenario}

There have been three main pension reforms in the past decade, in 1997, 2000 and 2005. The modelling aims to capture the cumulated effects of these reforms since 1997.

The pre-reform accrual rate was $2 \%$ per year. The earnings measure was the best 15 years of earnings, valorised in line with prices.

The early retirement age was increased from 60 for men in 2000 to 61.5 in 2002. For women, the age was increased from 55 to 56.5. The 1997 reform introduced for the first time a reduction for early retirement of $2 \%$ per year.

\section{Pension modelling results: Austria}

\section{Earnings-related}
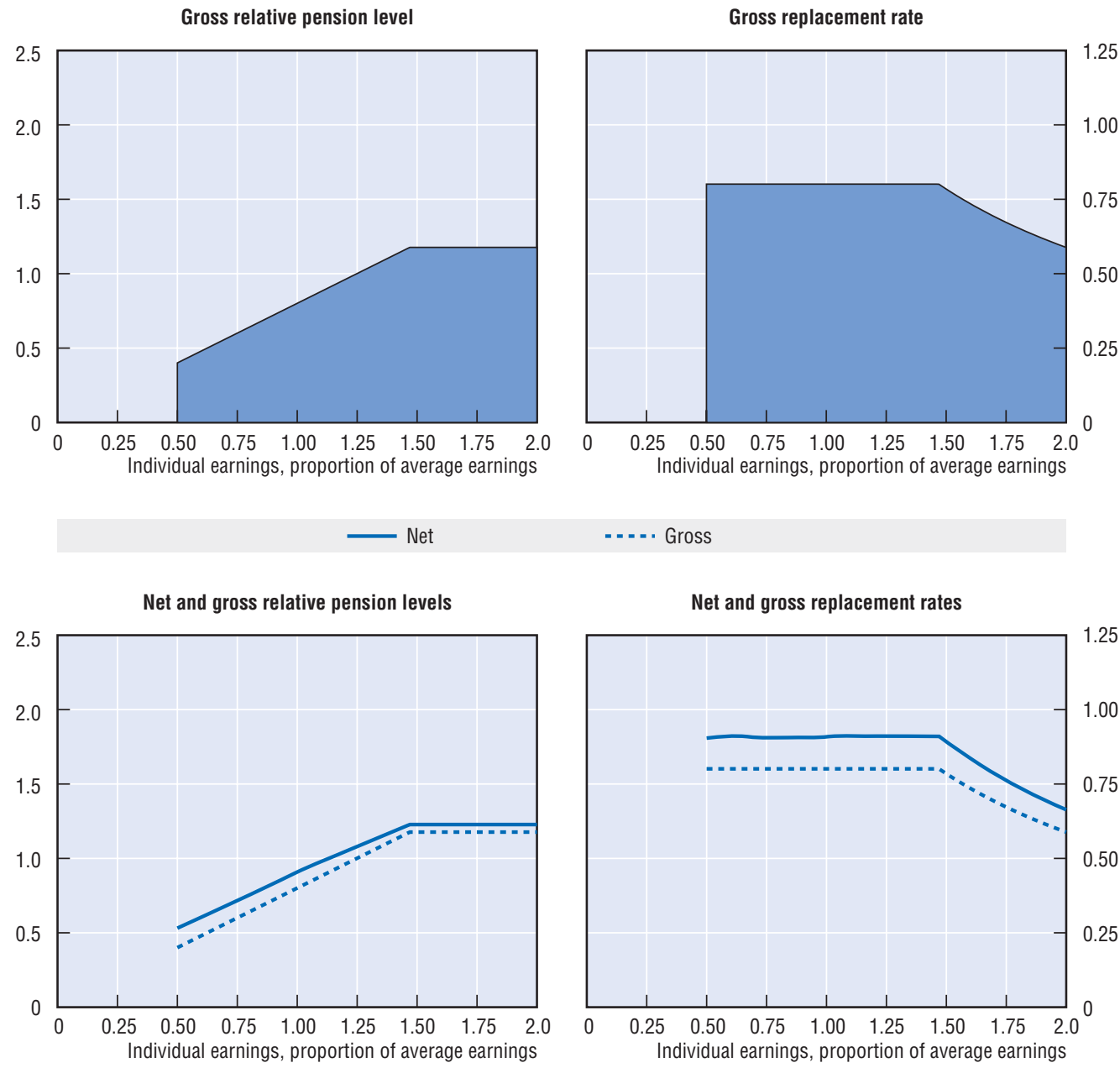


\begin{tabular}{|c|c|c|c|c|c|c|}
\hline \multirow{2}{*}{$\begin{array}{l}\text { Men } \\
\text { Women (where different) }\end{array}$} & \multirow{2}{*}{ Median earner } & \multicolumn{5}{|c|}{ Individual earnings, multiple of economy-wide average } \\
\hline & & 0.5 & 0.75 & 1 & 1.5 & 2 \\
\hline Gross relative pension level & 68.1 & 40.0 & 60.1 & 80.1 & 117.7 & 117.7 \\
\hline \multicolumn{7}{|l|}{ (\% average gross earnings) } \\
\hline Net relative pension level & 79.3 & 53.2 & 71.5 & 90.9 & 122.8 & 122.8 \\
\hline \multicolumn{7}{|l|}{ (\% net average earnings) } \\
\hline Gross replacement rate & 80.1 & 80.1 & 80.1 & 80.1 & 78.5 & 58.8 \\
\hline \multicolumn{7}{|l|}{ (\% individual gross earnings) } \\
\hline Net replacement rate & 90.6 & 90.4 & 90.6 & 90.9 & 89.2 & 66.4 \\
\hline \multicolumn{7}{|l|}{ (\% individual net earnings) } \\
\hline Gross pension wealth & 12.0 & 12.2 & 12.2 & 11.7 & 10.8 & 8.1 \\
\hline (multiple of individual gross earnings) & 14.0 & 14.2 & 14.2 & 13.5 & 12.5 & 9.4 \\
\hline Net pension wealth & 9.5 & 11.0 & 9.8 & 9.0 & 7.7 & 5.7 \\
\hline (multiple of individual gross earnings) & 11.0 & 12.8 & 11.5 & 10.4 & 8.8 & 6.6 \\
\hline
\end{tabular}

\section{Pension modelling results: Austria, pre-reform scenario}

\begin{tabular}{|c|c|c|c|c|c|c|}
\hline \multirow{2}{*}{$\begin{array}{l}\text { Men } \\
\text { Women (where different) }\end{array}$} & \multirow{2}{*}{ Median earner } & \multicolumn{5}{|c|}{ Individual earnings, multiple of economy-wide average } \\
\hline & & 0.5 & 0.75 & 1 & 1.5 & 2 \\
\hline Gross relative pension level & 76.5 & 45.0 & 67.5 & 90.0 & 132.2 & 132.2 \\
\hline (\% average gross earnings) & 68.0 & 40.0 & 60.0 & 80.0 & 117.5 & 117.5 \\
\hline Net relative pension level & 87.4 & 57.8 & 78.7 & 99.5 & 135.0 & 135.0 \\
\hline (\% net average earnings) & 79.2 & 53.1 & 71.5 & 90.8 & 122.6 & 122.6 \\
\hline Gross replacement rate & 90.0 & 90.0 & 90.0 & 90.0 & 88.2 & 66.1 \\
\hline (\% individual gross earnings) & 80.0 & 80.0 & 80.0 & 80.0 & 78.4 & 58.8 \\
\hline Net replacement rate & 99.9 & 98.3 & 99.6 & 99.5 & 98.1 & 73.0 \\
\hline (\% individual net earnings) & 90.5 & 90.3 & 90.5 & 90.8 & 89.1 & 66.3 \\
\hline Gross pension wealth & 13.7 & 13.7 & 13.7 & 13.7 & 13.4 & 10.1 \\
\hline (multiple of individual gross earnings) & 16.4 & 16.4 & 16.4 & 16.4 & 16.1 & 12.1 \\
\hline Net pension wealth & 10.6 & 11.9 & 10.8 & 10.3 & 9.3 & 7.0 \\
\hline (multiple of individual gross earnings) & 12.9 & 14.8 & 13.2 & 12.6 & 11.4 & 8.5 \\
\hline
\end{tabular}




\section{Belgium}

$\mathrm{T}_{\mathrm{h}}$ he pension system has two components: an earnings-related public scheme with a minimum pension and a means-tested safety net.

\section{Qualifying conditions}

With 34 years' contributions, the pension can be claimed at 60 under the 2004 rules. This contribution condition will increase to 35 years from 2005. Since a full-career worker from age 20 will meet this condition, the modelling assumes that people draw the pension from age 60.

Normal pensionable age is 65 for men. For women, the eligibility age in 2004 was 63 . It will increase to 64 in 2006 and 65 in 2009.

\section{Benefit calculation}

\section{Earnings-related}

The full replacement rate for a single pensioner is $60 \%$ and for those with a dependent spouse, $75 \%$. The annual accrual rate is therefore $60 / 45=1.33 \%$ for men and women. The earnings measure is average lifetime pay. Earlier years' earnings are revalued in line with prices.

The full pension is paid provided the qualifying conditions above are met. For shorter contribution histories, the pension is proportionally reduced.

There is a ceiling to pensionable earnings of EUR 41564.11 for 2004 (around 117\% of average earnings).

Pensions in payment are uprated in line with a consumer price index (that excludes some goods). There have also been discretionary real increases (called "adaptations to well-being"). However, these increments have recently been very limited (either to the lowest or the longest-running pensions). From 2008 on, the government will have to make decisions on uprating of all pensions every two years.

There are additional payments ("holiday" and "supplementary" allowances) payable once a year. These are equal to the value of the monthly pension up to a ceiling of EUR 505 for a single person and EUR 631 for pensioners with a dependent spouse.

\section{Minimum}

There is a minimum annual credit designed to increase pension entitlements for people with low earnings and/or in part-time work. Annual earnings of less than EUR 14520.06 (equivalent to $41 \%$ of average earnings) are inflated to this level. To qualify for the minimum credits, at least 15 years' insurance is necessary. (This gives an effective minimum pension for a full-career worker of EUR 11959.67 for a single person, worth 34\% of average earnings.)

There is also a minimum earnings-related pension of EUR 10191.95 for a single person (EUR 12735.92 with a dependent spouse) meeting the full contribution condition. For a single person, this is around $29 \%$ of average earnings. The benefit will be a proportion of this minimum in the case of less-than-full careers, if the beneficiary has at least two-thirds of the full number of years. In the other case, the benefit value will simply be obtained 
through the application of the benefit formula (there will be no "levelling up" of the benefit in line with the minimum pensions).

The minimum pension is indexed to prices, excluding certain goods. Benefits are increased by $2 \%$ each time cumulative inflation exceeds a certain threshold $(2 \%)$ since the last adjustment.

Pensioners will receive the higher of the minimum pension described here and the pension calculated according to minimum annual credit.

\section{Targeted}

The safety-net income for the elderly is EUR 7889.28 for a pensioner living alone (22\% of average earnings) and EUR 5259.48 for an older person living with others. Indexation is again to prices excluding certain goods.

\section{Early retirement}

Early retirement is possible from age 60, subject to 34 years' contributions in 2004 rising to 35 years in 2005. There is no actuarial reduction in the pension calculation. The pension, however, will be incomplete, due to the shortened career. There is an earnings test limiting the opportunity to combine an early retirement pension with work. This is more strict than the earnings test applied after normal pension age (see below).

\section{Late retirement}

It is possible to defer pension after the normal retirement age for people who continue working. Work after the age of 62 or beyond 44 years of contributions is credited with a bonus. Working after normal retirement age can also be used to plug career gaps to obtain a full pension or can improve the pension amount, since only the 45 last years are used in the calculation.

It is possible to combine pensions and earnings (after normal pension age) within limits. For annual earnings under EUR 13556.68 (single) or EUR 17267.48 (with a dependent child), the pensions will not be reduced. The threshold for a single person is worth $38 \%$ of average earnings. Above this ceiling, the pension will be reduced by the amount that earnings surpass these limits. If actual earnings are $15 \%$ above the limits then the pension will be completely withdrawn. 


\section{Pension modelling results: Belgium}

Earnings-related

Minimum

Targeted

Gross relative pension level

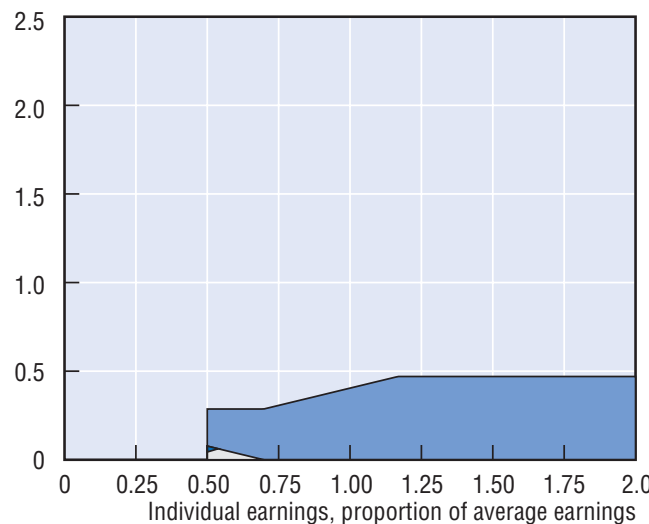

Net

Net and gross relative pension levels

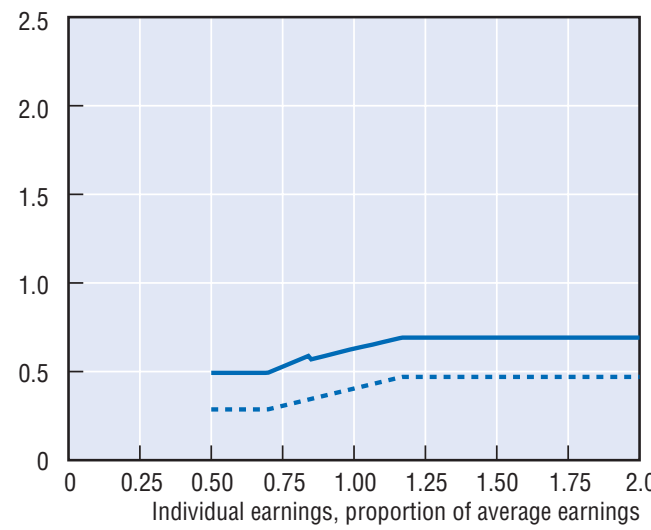

Gross replacement rate

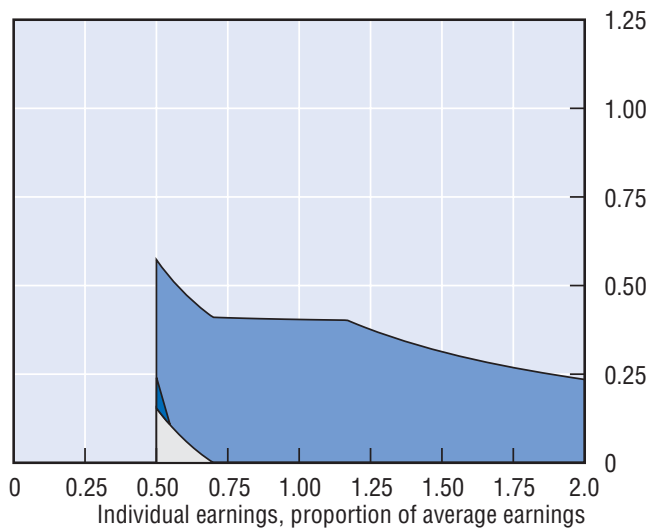

- . ... Gross

Net and gross replacement rates

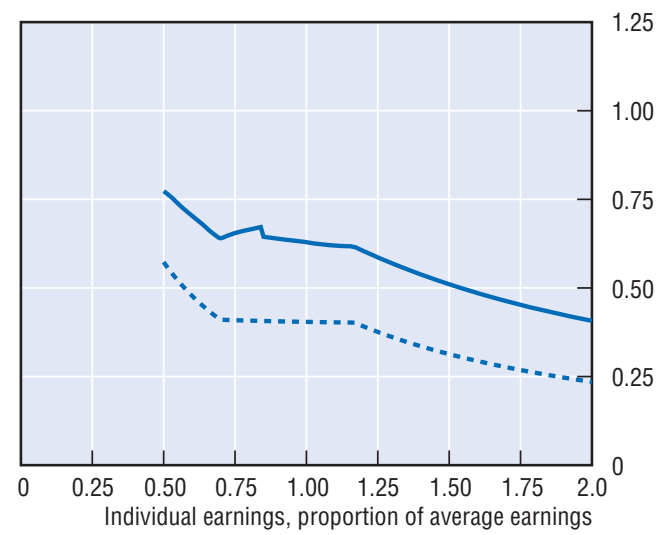

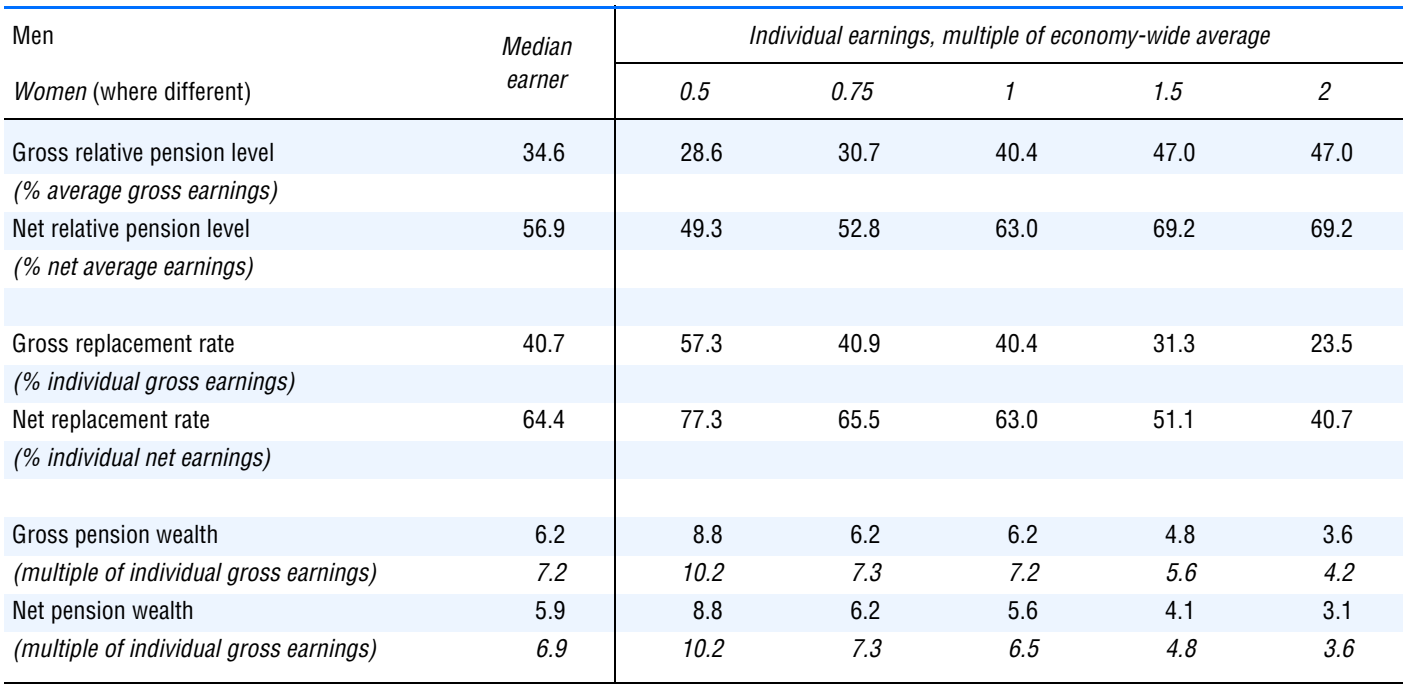




\section{Canada}

$\mathrm{T}_{\mathrm{r}}$ he pension system offers a universal flat-rate benefit, which can be topped up with an income-tested benefit, and earnings-related public schemes.

\section{Qualifying conditions}

The basic old age security (OAS) pension is subject to a residence test, with $1 / 40$ th of the maximum pension earned for each year of residence after age 18 up to a maximum of 40 years. A minimum of ten years' residence is required to receive any benefit. It is payable from age 65.

For the earnings-related scheme, a full pension requires about 40 years' contributions but a single valid contribution is sufficient to generate an entitlement. Normal pension eligibility age is 65 but an early pension can be claimed from age 60 .

\section{Benefit calculation}

\section{Basic}

The average 2004 payment for the OAS pension was CAD 5376 , while the full pension level was CAD 5 592.75. The full pension is equivalent to $14.4 \%$ of average earnings. The value of the basic pension is price-indexed.

This pension is subject to an income test operated through the tax system (a "clawback"). For income above CAD 59790 a year, the basic pension in 2004 was withdrawn at a $15 \%$ rate. This threshold was equivalent to $154 \%$ of average earnings. It is also indexed to prices.

\section{Targeted}

The guaranteed income supplement (GIS) is added to the basic OAS pension. The combination gave a maximum benefit of CAD 12239.67 in 2004. The average combined basic pension and supplementary benefit was $31.4 \%$ of average earnings for a single person.

The GIS is reduced against income other than the basic pension at a $50 \%$ rate. The target benefit level is price-indexed.

\section{Earnings-related}

Earnings-related pensions and benefits are provided by the Canada Pension Plan (CPP)/ Québec Pension Plan (QPP). The CPP and QPP offer broadly similar benefits. The scheme targets a replacement rate of $25 \%$ of earnings, based on average lifetime salary (excluding the $15 \%$ of years with the lowest earnings). Earlier years' pay is revalued in line with economy-wide earnings. As noted previously, the full benefit requires about 40 years' contributions with proportional reductions for shorter work histories. The maximum earnings-related retirement pension for 2004 was CAD 814.17 a month (a quarter of average earnings).

People earning less than CAD 3500 a year are not required to contribute. There was a ceiling of CAD 40500 in 2004 (96\% of average earnings) to contributions. The ceiling is indexed to increases in average earnings while the contribution floor is frozen in nominal terms. 
The value of the earnings-related pension after retirement is uprated annually in line with prices.

\section{Early retirement}

Early retirement beginning at age 60 is possible in the state earnings-related scheme subject to a benefit reduction of $6 \%$ per year. Early retirement is not possible in the other two public schemes (basic and means-tested).

\section{Late retirement}

The earnings-related pension can be deferred earning a $6 \%$ increment for each year after age 65 - up to a maximum of five years. The basic and income-tested benefits cannot be deferred. The income-test for the latter includes earnings, for the former there is a clawback against large incomes, again including earnings.

\section{Pension modelling results: Canada}

Earnings-related

Gross relative pension level

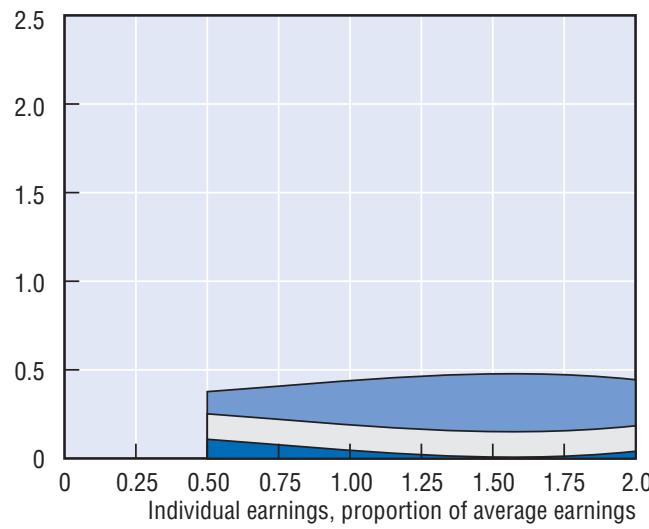

Net

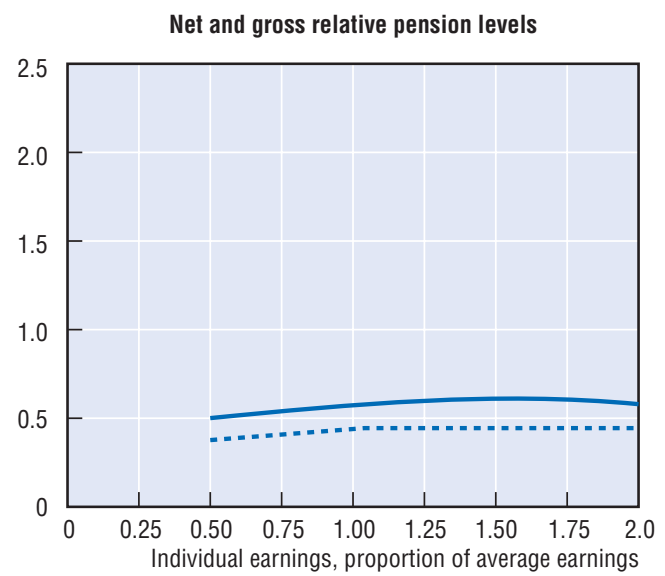

Gross replacement rate

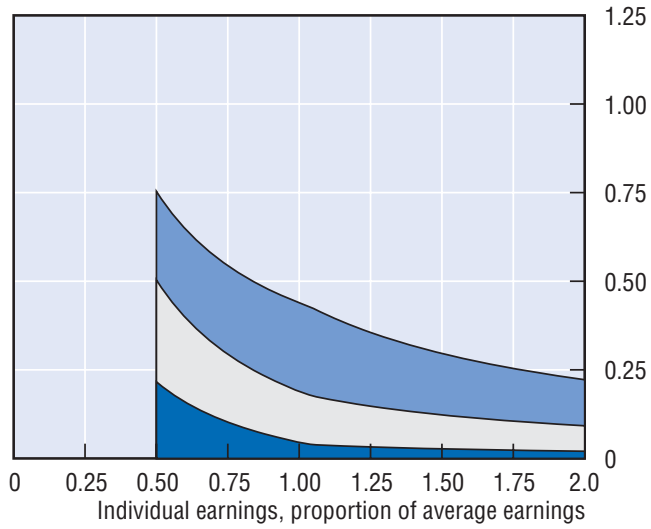

.... - Gross

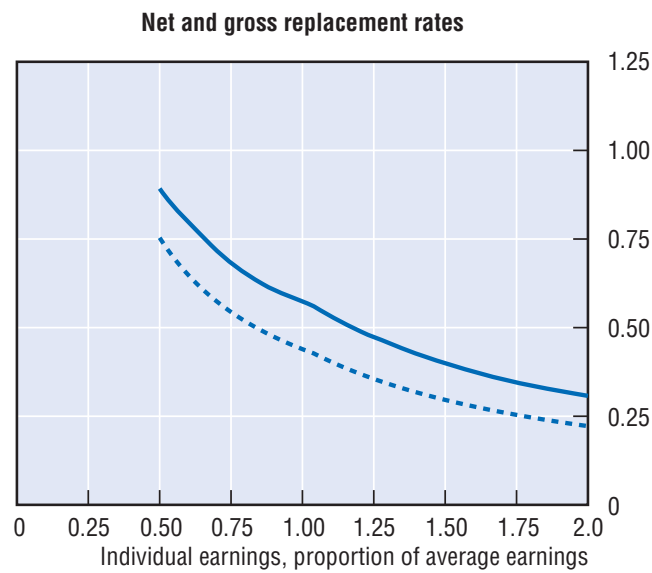




\begin{tabular}{|c|c|c|c|c|c|c|}
\hline \multirow{2}{*}{$\begin{array}{l}\text { Men } \\
\text { Women (where different) }\end{array}$} & \multirow{2}{*}{ Median earner } & \multicolumn{5}{|c|}{ Individual earnings, multiple of economy-wide average } \\
\hline & & 0.5 & 0.75 & 1 & 1.5 & 2 \\
\hline Gross relative pension level & 42.1 & 37.7 & 40.8 & 43.9 & 44.4 & 44.4 \\
\hline \multicolumn{7}{|l|}{ (\% average gross earnings) } \\
\hline Net relative pension level & 55.3 & 50.1 & 53.9 & 57.4 & 58.0 & 58.0 \\
\hline \multicolumn{7}{|l|}{ (\% net average earnings) } \\
\hline Gross replacement rate & 49.5 & 75.4 & 54.4 & 43.9 & 29.6 & 22.2 \\
\hline \multicolumn{7}{|l|}{ (\% individual gross earnings) } \\
\hline Net replacement rate & 62.8 & 89.2 & 68.3 & 57.4 & 40.0 & 30.8 \\
\hline \multicolumn{7}{|l|}{ (\% individual net earnings) } \\
\hline Gross pension wealth & 7.6 & 11.5 & 8.3 & 6.7 & 4.5 & 3.4 \\
\hline (multiple of individual gross earnings) & 8.8 & 13.4 & 9.7 & 7.8 & 5.3 & 4.0 \\
\hline Net pension wealth & 7.5 & 11.5 & 8.3 & 6.6 & 4.4 & 3.3 \\
\hline (multiple of individual gross earnings) & 8.7 & 13.4 & 9.6 & 7.7 & 5.2 & 3.9 \\
\hline
\end{tabular}




\section{Czech Republic}

$\mathrm{T}$

he public pension scheme has a basic element and an earnings-related part calculated according to a progressive formula. There is also a minimum pension.

\section{Qualifying conditions}

The standard retirement age will be gradually increased to 63 for men born in 1953 and later. The pension eligibility age will be 59-62 for women with children (depending on the number of children that they raised) and 63 for women without children. 25 years' coverage is required as a minimum but people with 15 years' contributions can receive a pension from 65 .

\section{Benefit calculation}

\section{Basic}

The value of the basic pension is CZK 1400 per month, equivalent to $8 \%$ of earnings. There is no statutory indexation requirement for the value of the basic benefit alone. However, total pensions in payment must be increased by at least prices plus one third of real wage growth (see below).

\section{Earnings-related}

The earnings-related pension gives $1.5 \%$ of earnings for each year of contributions. The earnings measure currently averages across all years since 1985, but it will gradually reach 30 years (in 2015). Earlier years' earnings are valorised by the growth of economywide average earnings.

There is a progressive benefit formula, with the first CZK 8400 per month replaced at $100 \%$, the slice of earnings between this limit and CZK 20500 at 30\% with 10\% replacement above this level. The first threshold, below which there is $100 \%$ replacement, is equivalent to $48 \%$ of average earnings, while the second threshold is $117 \%$ of average earnings. There is no statutory indexation requirement for these thresholds, but both these thresholds have changed annually.

There is no specific statutory indexation requirement for the earnings-related pension component in payment. However, the combined total pension benefit (flat-rate and earnings-related components) is adjusted at least to price inflation plus at least one third of real wage growth.

\section{Minimum}

The total value of the minimum monthly pension benefit is CZK 2 170, which is made up of a minimum earnings-related pension of CZK 770 plus the basic component of CZK 1400 . This combined minimum pension is indexed in the same way as described above. It is worth $12.4 \%$ of average earnings.

\section{Social assistance}

Older people are covered by the general social-assistance scheme and related benefits in kind. The target safety-net income for a single-person household is CZK 4300 per 
month, or $26.4 \%$ of average earnings. This is made up of a personal needs amount of CZK 2360 plus a household needs amount of CZK 1940.

\section{Early retirement}

It is possible to retire three years before the normal ages, i.e. at 60 for men and 56-60 for women subject to 25 years' contributions. The total accrual factor (i.e., number of years of contributions multiplied by the accrual rate) is permanently reduced by $0.9 \%$ for each 90 days of early retirement (3.6\% per year). For a full-career worker, this is equivalent to a decrement in the pension level (rather than the replacement rate) for early retirement of $3.6 / 64.5(1.5 \%$ times 43 years $)=5.6 \%$.

\section{Late retirement}

It is possible to defer claiming the pension beyond the normal pension age. The total accrual factor (see section on early retirement above) is increased by $1.5 \%$ for each 90 -day period of deferral (6\% per year). There is no additional pension accrual for deferred retirement. It is also possible to combine pension receipt while continuing to work.

\section{Further reading}

Hemmings, P. and E.R. Whitehouse. (2006), "Assessing the 2005 Czech Proposals for Pension Reform", Working Paper No. 496, Economics Department, OECD, Paris.

OECD (2006), "Ensuring Fiscal Sustainability: Assessing Recent Proposals for Pension Reform", Chapter 2 of OECD Economic Surveys: Czech Republic, OECD, Paris. 


\section{Pension modelling results: Czech Republic}

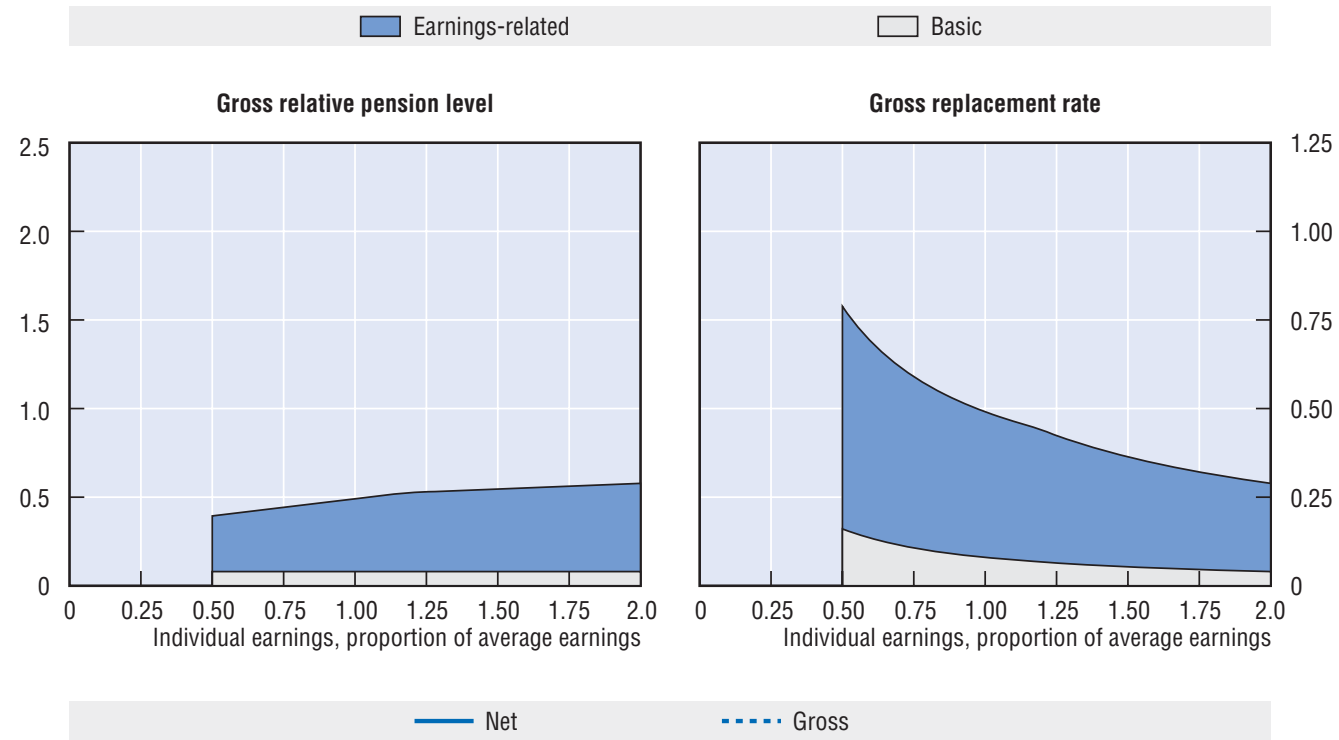

Net and gross relative pension levels

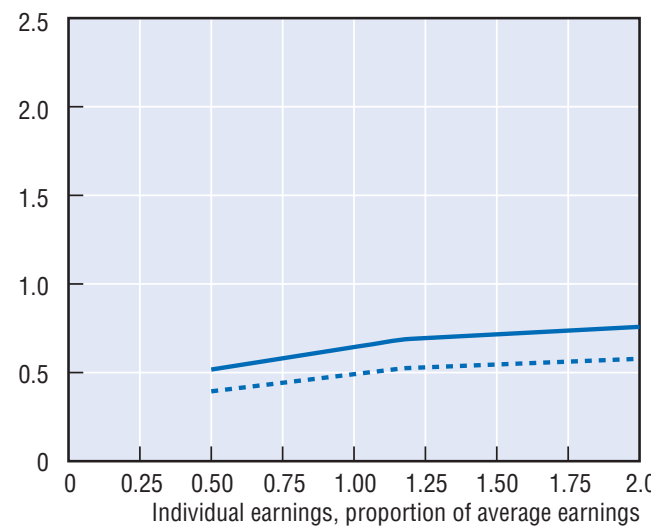

Net and gross replacement rates

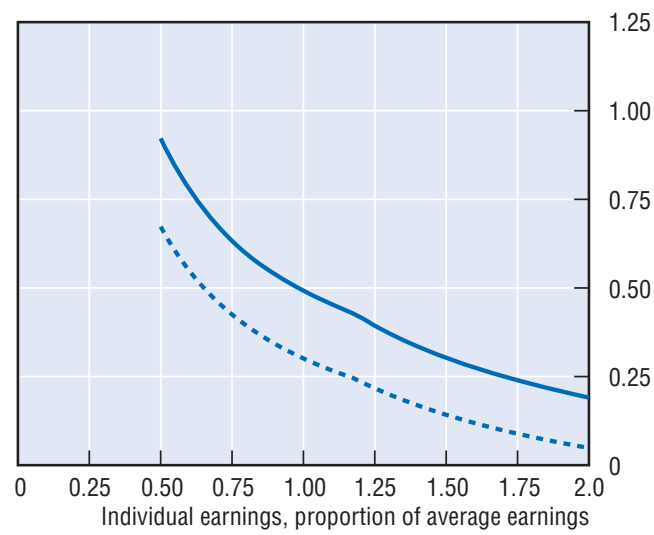

\begin{tabular}{|c|c|c|c|c|c|c|}
\hline \multirow{2}{*}{$\begin{array}{l}\text { Men } \\
\text { Women (where different) }\end{array}$} & \multirow{2}{*}{$\begin{array}{l}\text { Median } \\
\text { earner }\end{array}$} & \multicolumn{5}{|c|}{ Individual earnings, multiple of economy-wide average } \\
\hline & & 0.5 & 0.75 & 1 & 1.5 & 2 \\
\hline Gross relative pension level & 46.2 & 39.4 & 44.3 & 49.1 & 54.6 & 57.8 \\
\hline \multicolumn{7}{|l|}{ (\% average gross earnings) } \\
\hline Net relative pension level & 60.6 & 51.7 & 58.1 & 64.4 & 71.6 & 75.8 \\
\hline \multicolumn{7}{|l|}{ (\% net average earnings) } \\
\hline Gross replacement rate & 54.3 & 78.8 & 59.0 & 49.1 & 36.4 & 28.9 \\
\hline \multicolumn{7}{|l|}{ (\% individual gross earnings) } \\
\hline Net replacement rate & 70.3 & 98.8 & 75.6 & 64.4 & 49.3 & 40.2 \\
\hline \multicolumn{7}{|l|}{ (\% individual net earnings) } \\
\hline Gross pension wealth & 8.9 & 13.0 & 9.7 & 8.1 & 6.0 & 4.8 \\
\hline (multiple of individual gross earnings) & 10.5 & 15.3 & 11.4 & 9.5 & 7.0 & 5.6 \\
\hline Net pension wealth & 8.9 & 13.0 & 9.7 & 8.1 & 6.0 & 4.8 \\
\hline (multiple of individual gross earnings) & 10.5 & 15.3 & 11.4 & 9.5 & 7.0 & 5.6 \\
\hline
\end{tabular}




\section{Denmark}

$\mathrm{T}$ he public scheme (folkepension) consists of a basis amount and an income-tested pension supplement. A means-tested supplementary pension benefit is paid to the financially most disadvantaged pensioners. There are also two schemes based on individuals' contribution records, the ATP (the Danish Labour Market Supplementary Pension) and the SP (the Special Pension savings scheme). In addition, compulsory occupational schemes negotiated as part of collective agreements cover about $90 \%$ of full-time employees.

\section{Qualifying conditions}

The normal pension age is 65 (67 for people born before 1 July 1939). A full public old-age pension requires 40 years' residence. Shorter periods qualify for a pro-rated benefit (subject to a minimum of three years' residence).

A full entitlement under the labour-market supplementary pension (ATP) and the special saving scheme (SP) requires a full career of contributions. The ATP scheme was established in 1964 and the SP scheme in 1999.

\section{Benefit calculation}

\section{Basic}

The full basic pension amount is DKK 4648 per month or DKK 55776 per year, equivalent to $17.6 \%$ of average earnings. There is an earnings test which means that the benefit will be reduced if pay exceeds DKK 237000 per year (three-quarters of average earnings). The benefit is withdrawn at a rate of $30 \%$ against earnings above this level.

\section{Targeted}

The full pension supplement is DKK 4679 per month or DKK 56148 per year for single persons (17.7\% of average earnings). The amounts are tested against all sources of income (including ATP, SP and occupational pensions) apart from the basic pension amount. The pension supplement is withdrawn once income exceeds DKK 52300 a year for single persons (16.5\% of average earnings). The withdrawal rate is $30 \%$ of income above the threshold for a single person.

Connected with the public old-age pension, a new supplementary pension benefit of DKK 6200 (2005) a year was introduced in 2004. The supplementary pension benefit is taxable and paid once a year. The benefit is means-tested and targeted to the poorest pensioners.

The public old-age pension (the basic amount and the pension supplement) and the supplementary pension benefit are adjusted annually in line with average earnings. The adjustment is based on an index of wage increases during the two preceding years. If nominal earnings growth exceeds $2 \%$, a maximum of 0.3 percentage points of the excess increase is allocated to a social spending reserve. Thus, indexation of pensions and other social benefits is based upon wage increases less any allocation to the reserve.

\section{Occupational}

These schemes are fully funded defined-contribution schemes agreed between the social partners. Coverage of these schemes is almost universal. Contributions are typically between $9 \%$ and $17 \%$ of earnings. In 2006, the percentage for the majority of Danish workers has been raised to $10.8 \%$ and this contribution rate is used for the modelling. 
Benefits are usually withdrawn as an annuity. The assumed interest rate is $1.5 \%$ for recent contributions or new schemes. However, the schemes operate on a "with-profit" basis, with pension increases depending on the return on assets and mortality experience of the fund. Many schemes also allow lump-sum withdrawals. Since 2000, the annuity calculation must use unisex mortality tables.

\section{Defined contribution (ATP)}

Technically, the ATP scheme pays a deferred annuity. Contributions are split with twothirds paid by the employer and one-third by the worker. The contribution amount reflects the number of hours worked. The contribution schedule against hours worked is shown in the following table (for monthly paid workers):

\begin{tabular}{lcccc}
\hline Monthly hours & $<39$ & $39-77$ & $78-116$ & 116 \\
\hline Contribution, DKK/month up until 2006 & 0 & 74.55 & 149.10 & 223.65 \\
Contribution, DKK/month as from 2006 & 0 & 81.30 & 162.60 & 243.90 \\
\hline
\end{tabular}

Thus, a full-time employee in the private sector paid DKK 2684 in 2005 - a nominal figure, which has applied since 1996. The value of the contribution is adjusted if and when the social partners decide to do so as part of collective agreements. Over the past 20 years the contribution has been increased in steps more or less in line with average earnings. The modelling assumes that the contribution will increase in line with average earnings. However, an increase of $9 \%$ has been agreed for 2006.

Until 2002, each DKK 396 of contributions earned DKK 100 of pension benefits paid from 67 regardless of the age at which they were made. This implied an interest rate of around 4.5\%. From 2002, a nominal interest rate of $1.5 \%$ has been assumed. ATP is a "with-profit" scheme: if actual returns exceed $4.5 \%$ or $1.5 \%$ respectively, pensions may be increased. In the model, it is assumed that the ATP earns the same interest rate as assumed for funded DC schemes in other OECD countries.

The ATP scheme increases pensions in payment and pension rights alike if its financial condition allows. This is done in the form of bonus allowances which reflect the difference in implicit interest rates for contributions made before and after 2002.

The modelling assumes full indexation to price inflation.

\section{Defined contribution (Special pension, SP)}

Employees, self-employed and recipients of unemployment and sickness benefits contribute $1 \%$ of earnings to this mandatory individual retirement savings scheme. Investments are currently managed centrally. As from 2005, members have been able to choose their manager and portfolio. There is no ceiling to earnings covered by this scheme. Benefits are paid at age 65. If the account balance is less than DKK 15000 , it is paid as a lump sum. If it is between DKK 15000 and DKK 120000 , then $1 / 10^{\text {th }}$ of the balance is paid out in the first year, $1 / 9$ th the next year etc. If the balance is more than DKK 120000 at age 65 , then the payments are monthly with annual adjustments to reflect the market value of the account.

As part of an economic-policy agreement, contributions for the SP scheme have been suspended since 2004 in order to boost consumption and increase employment. The model takes a long-term perspective and so assumes that SP contributions resume. 


\section{Early retirement}

There is a partial early retirement pension for workers aged between 60 and 65 who continue to work for 12 to 30 hours a week. The beneficiary must reduce weekly hours worked by at least seven hours a week or at least one quarter of total hours worked in an average week. The partial pension is calculated as a fixed amount for every hour that is reduced. The amount is approximately DDK 71 an hour for 2004. Since 1999, beneficiaries are subject to a pension deduction.

People covered by either early-retirement programme revert to the standard old-age pension once they reach the normal retirement age of 65 .

\section{Late retirement}

It is possible to defer the public old age pension for up to ten years. The increment for deferring pension for a year is the ratio of the period of deferral to average life expectancy at the time the pension is drawn. For example, the World Bank/UN population projections show life expectancy for a 66-year-old to be 18.7 years. Thus, the increment for deferring for a year from age 65 would be $1 / 18.7=5.3 \%$.

\section{Pension modelling results: Denmark}
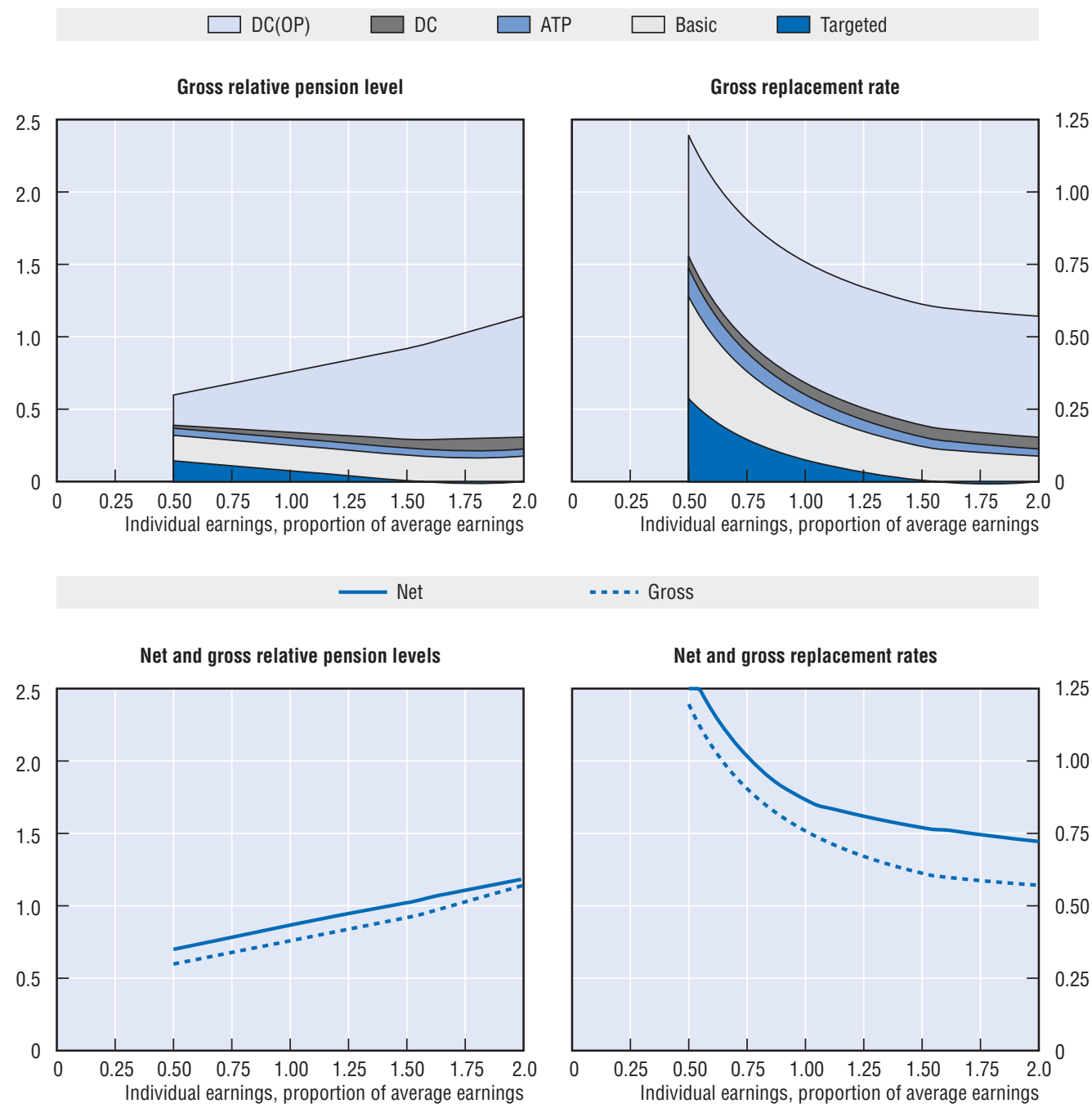


\begin{tabular}{|c|c|c|c|c|c|c|}
\hline \multirow{2}{*}{$\begin{array}{l}\text { Men } \\
\text { Women (where different) }\end{array}$} & \multirow{2}{*}{ Median earner } & \multicolumn{5}{|c|}{ Individual earnings, multiple of economy-wide average } \\
\hline & & 0.5 & 0.75 & 1 & 1.5 & 2 \\
\hline Gross relative pension level & 71.0 & 59.8 & 67.8 & 75.8 & 91.9 & 114.2 \\
\hline \multicolumn{7}{|l|}{ (\% average gross earnings) } \\
\hline Net relative pension level & 81.6 & 69.9 & 78.3 & 86.7 & 102.2 & 118.6 \\
\hline \multicolumn{7}{|l|}{ (\% net average earnings) } \\
\hline Gross replacement rate & 83.6 & 119.6 & 90.4 & 75.8 & 61.3 & 57.1 \\
\hline \multicolumn{7}{|l|}{ (\% individual gross earnings) } \\
\hline Net replacement rate & 94.1 & 132.7 & 101.6 & 86.7 & 77.0 & 72.2 \\
\hline \multicolumn{7}{|l|}{ (\% individual net earnings) } \\
\hline Gross pension wealth & 13.2 & 19.5 & 14.4 & 11.9 & 9.4 & 8.7 \\
\hline (multiple of individual gross earnings) & 15.2 & 22.3 & 16.5 & 13.6 & 10.7 & 9.9 \\
\hline Net pension wealth & 8.9 & 13.4 & 9.8 & 8.0 & 6.1 & 5.3 \\
\hline (multiple of individual gross earnings) & 10.3 & 15.4 & 11.2 & 9.2 & 7.0 & 6.1 \\
\hline
\end{tabular}




\section{Finland}

$\mathrm{T}$ he two-tier pension system consists of a basic national pension, which is incometested, and a range of statutory earnings-related schemes, with very similar rules for different groups. The modelling covers the scheme for private sector employees (TEL). The schemes for private-sector employees are partially pre-funded while the public-sector schemes are pay-as-you-go financed (with buffer funds to even out future increases in pension contributions). Major pension reform was introduced in Finland in 2005. The rules presented here refer to long-term situation when all reforms are fully phased-in.

\section{Qualifying conditions}

The national pension is subject to a residency test and withdrawn against pension income from the earnings-related schemes. The national old-age pension is payable from age 65 . The full national pension benefit is payable with 40 years residence as an adult, with pro-rata adjustments for shorter periods of residence. Early retirement on the age national pension is possible from age 62 .

In the earnings-related pension scheme, the retirement age is flexible between 63 and 68 (from 2005). In addition, early retirement is possible at age 62 and the pension can be deferred beyond age 68 .

\section{Benefit calculation}

\section{Earnings-related}

From 2005 , the accrual rate is $1.5 \%$ of pensionable earnings at ages $18-52,1.9 \%$ at ages 53-62 and 4.5\% at ages 63-67. For a full-career worker working from age 20 until retirement at age 65 , the total lifetime accrual will be $77.5 \%$ of pensionable earnings. The earnings measure is based on lifetime average earnings. In the calculation, however, the employee's pension contribution is deducted. Note, however, that the replacement rates are shown relative to total gross earnings.

Earlier years' earnings are re-valued in line with a mix of economy-wide earnings and prices. From 2005, wage growth has an $80 \%$ weight and price inflation, $20 \%$. After retirement, the earnings-related pension is uprated using a formula of $20 \%$ of earnings inflation and $80 \%$ of price inflation.

From 2010, newly awarded benefits will be reduced according to increases in life expectancy. The calculations use lagged mortality data: for 2010, for example, the data are the average for 2004-2008 compared to the base year which in turn results from data for 2003-07. Between 2002 and 2040, the UN/World Bank mortality projections imply an increase in life expectancy at age 65 from 16.8 years to 20.4 (calculated from unisex mortality rates). The adjustment takes the form of an annuity calculation using a discount rate of $2 \%$ per year. The adjustment is expected to reduce benefits to $88.6 \%$ of their value under the pre-reform rules by 2040. The life expectancy coefficient is calculated for each cohort at the age of 62 .

There is no contribution floor and no ceiling to contributions or pensionable earnings. However, there are minimum earnings limit for pension insurance.

\section{Minimum}

The parameters of the national pension scheme differ between municipalities. The full basic monthly benefit for a single pensioner in 2004 was EUR 496.38 in the first 
municipality group and EUR 475.73 in the second municipality group, corresponding to just below a fifth of average earnings. The national pension is reduced by $50 \%$ of the difference between other pension income and a small disregard which in 2004 was EUR 559 per year. No pension is payable once other pension income exceeds EUR 1016.96 or EUR 975.58 per month, depending on municipality group. Note that the modelling uses the higher value for the national pension.

From 2005 on, earnings-related pension rights accrued after the age of 63 will be disregarded when national pension entitlement is calculated.

The basic pension benefit, the parameters of the means test, and pensions in payment are uprated annually in line with prices. In practice there have been additional increases based on separate decisions. Note that the modelling assumes uprating with earnings over the long term.

\section{Early retirement}

Early retirement is possible in the national pension scheme from age 62. From 2005, the pension is permanently reduced by $0.4 \%$ for each month of retirement before the age of 65 .

Early retirement is also possible at age 62 under the earnings-related scheme, subject to a $0.6 \%$ benefit reduction per month of early retirement until the age of 63 . After the age of 63 there is no benefit reduction.

\section{Late retirement}

From 2004 the national pension can be deferred after the age of 65 and the pension is then increased by $0.6 \%$ for each month by which retirement is postponed.

From 2005 onwards, the increment for late retirement is reduced to $0.4 \%$ for each month (4.8\% per year) in the earnings-related scheme after age 68 . There is no adjustment between ages 63 and 68 because of the accelerated accrual of pension at those ages.

It is possible to combine receipt of pension and earnings from work. From 2005, after taking the old-age pension, earnings accrue additional pension right with a rate of $1.5 \%$ per year until the age of 68 .

\section{Pre-reform scenario}

There have been several changes in the rules of different pension schemes since 1990 and the model uses 1990 rules as follows.

The normal pension age was 65 . The early pension eligibility age was 60 .

Before reform, there was a basic element to the national pension that was not resource-tested. In 1990, this amounted to FIM 390 per month.

The additional, pension-income-tested benefit was FIM 1824 per month for a single person. (Again, this varied by municipality: this is the figure for Helsinki.)

To derive parameters that would have applied in 1994 had the system not been reformed, the ratio of the basic to the national pension that applied in 1990 is used to calculate basic and pension-income-tested pension levels for 1994. These are EUR 1054 and EUR 4907 respectively.

The earnings-related scheme had a linear accrual rate of 1.5\% per year for each year of contributions in year 1990 . The entry age for earnings-related pensions was 23 , compared with 18 currently (i.e. no accrual before 23). There was no accrual from age 65 . 
Indexation of pensions in payment and valorisation of earlier years' earnings were both 50:50 to earnings and prices. From 1996, pension indexation changed from the age of 65 to $20 \%$ earnings inflation and $80 \%$ price inflation. For past earnings and to pensions payable to those under 65 , it remained at $50 \%$ earnings and $50 \%$ prices.

The earnings measure was based on the middle two of the final four years' earnings in each job (i.e., excluding the highest and lowest earnings of the final four years). There was no employees' pension contribution until 1993. Pensionable earnings were gross earnings until 1996, when pensionable pay was redefined as earnings less employees' pension contributions (see above).

The reduction for early retirement under the pre-reform earnings-related scheme was between $0.37 \%$ and $0.5 \%$ per month (4.44\%-6\% per year) depending on the year of birth of the recipient. The national pension was reduced by $0.5 \%$ per month of early retirement.

Deferral of pensions earned an increment of $1 \%$ per month for both earnings-related scheme and basic/national pension.

\section{Pension modelling results: Finland}
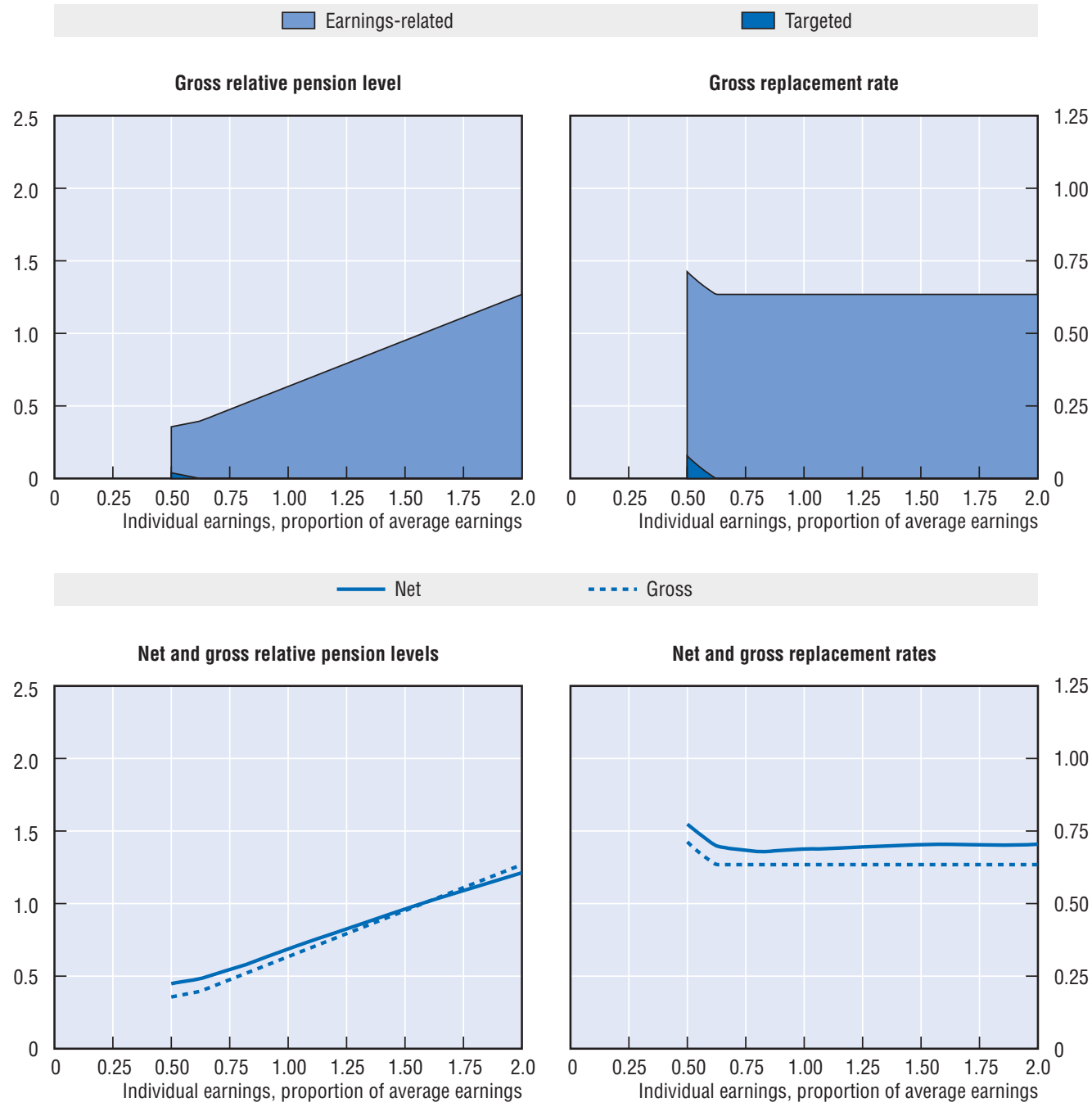


\begin{tabular}{|c|c|c|c|c|c|c|}
\hline \multirow{2}{*}{$\begin{array}{l}\text { Men } \\
\text { Women (where different) }\end{array}$} & \multirow{2}{*}{ Median earner } & \multicolumn{5}{|c|}{ Individual earnings, multiple of economy-wide average } \\
\hline & & 0.5 & 0.75 & 1 & 1.5 & 2 \\
\hline Gross relative pension level & 53.9 & 35.6 & 47.6 & 63.4 & 95.1 & 126.9 \\
\hline \multicolumn{7}{|l|}{ (\% average gross earnings) } \\
\hline Net relative pension level & 59.8 & 44.8 & 54.5 & 68.8 & 96.2 & 121.2 \\
\hline \multicolumn{7}{|l|}{ (\% net average earnings) } \\
\hline Gross replacement rate & 63.4 & 71.3 & 63.4 & 63.4 & 63.4 & 63.4 \\
\hline \multicolumn{7}{|l|}{ (\% individual gross earnings) } \\
\hline Net replacement rate & 68.0 & 77.4 & 68.4 & 68.8 & 70.3 & 70.5 \\
\hline \multicolumn{7}{|l|}{ (\% individual net earnings) } \\
\hline Gross pension wealth & 10.0 & 11.2 & 10.0 & 10.0 & 10.0 & 10.0 \\
\hline (multiple of individual gross earnings) & 11.8 & 13.2 & 11.8 & 11.8 & 11.8 & 11.8 \\
\hline Net pension wealth & 7.6 & 9.6 & 7.9 & 7.4 & 6.9 & 6.6 \\
\hline (multiple of individual gross earnings) & 9.0 & 11.4 & 9.3 & 8.8 & 8.2 & 7.8 \\
\hline
\end{tabular}

\section{Pension modelling results: Finland, pre-reform scenario}

\begin{tabular}{|c|c|c|c|c|c|c|}
\hline \multirow{2}{*}{$\begin{array}{l}\text { Men } \\
\text { Women (where different) }\end{array}$} & \multirow{2}{*}{ Median earner } & \multicolumn{5}{|c|}{ Individual earnings, multiple of economy-wide average } \\
\hline & & 0.5 & 0.75 & 1 & 1.5 & 2 \\
\hline Gross relative pension level & 56.9 & 35.5 & 50.6 & 66.3 & 97.8 & 129.3 \\
\hline \multicolumn{7}{|l|}{ (\% average gross earnings) } \\
\hline Net relative pension level & 62.3 & 44.6 & 56.5 & 71.0 & 98.0 & 122.4 \\
\hline \multicolumn{7}{|l|}{ (\% net average earnings) } \\
\hline Gross replacement rate & 66.9 & 71.1 & 67.5 & 66.3 & 65.2 & 64.7 \\
\hline \multicolumn{7}{|l|}{ (\% individual gross earnings) } \\
\hline Net replacement rate & 70.9 & 77.0 & 70.9 & 71.0 & 71.6 & 71.1 \\
\hline \multicolumn{7}{|l|}{ (\% individual net earnings) } \\
\hline Gross pension wealth & 11.1 & 11.7 & 11.2 & 11.0 & 10.8 & 10.8 \\
\hline (multiple of individual gross earnings) & 13.3 & 14.0 & 13.4 & 13.2 & 13.0 & 12.9 \\
\hline Net pension wealth & 8.4 & 10.1 & 8.6 & 8.1 & 7.5 & 7.0 \\
\hline (multiple of individual gross earnings) & 10.0 & 12.1 & 10.3 & 9.7 & 8.9 & 8.4 \\
\hline
\end{tabular}




\section{France}

$\mathrm{T}$ he pension system has two tiers: an earnings-related public pension and mandatory occupational schemes, based on a points system. The public scheme also has a minimum pension.

\section{Qualifying conditions}

A full state pension will require 40 years' contributions by 2008, compared with 37.5 years in the past. Between 2008 and 2012, this will then increase gradually to 41 years. After 2012, the minimum contribution will increase in line with increases in life expectancy so that the ratio of period of pension payment to period of working is kept constant. Normal pension age is 60 . The modelling assumes that a full career is from age 20 to 60 . The minimum pension has the same qualifying conditions as the public, earnings-related scheme.

\section{Benefit calculation}

\section{Earnings-related}

The state pension targets a replacement rate of 50\% after a full career (which will be 40 years' contributions and then increased further as described above). For each missing quarter, benefits are reduced by $1.25 \%$, giving a reduction (decote) per missing year of $5 \%$.

For contribution periods less than a full career, the target replacement rate is reduced pro rata and by an additional penalty for each years missing (or each year the pension is drawn before 65).

The earnings measure is based on a number of best years of earnings, valorised in line with price inflation. From 2008 onwards, pay will be averaged over 25 years. Currently, it is around 20 years.

Because of the limited number of years included in the earnings measure for calculating pension benefits and the policy of valorisation in line with prices, the replacement rate in the French public system is very sensitive to the time profile of earnings throughout the worker's career. Given the baseline assumption of continuous real earnings growth of $2 \%$ over a worker's career, combined with the fact that the OECD calculations use the lifetime revalued average earnings as reference salary, the replacement rates calculated are lower than those calculated using the observed salary progression in France, where pay increases are concentrated primarily in the first half of the career.

There is a ceiling on eligible earnings, which in 2004 was EUR 29712 . This is approximately equal to average earnings on the OECD measure (EUR 29549 ) but is $142 \%$ of average earnings on the national measure. Benefits in payment are indexed to prices.

\section{Minimum}

There is a minimum pension, which was EUR 6706 for the calendar year 2004. This is worth $23 \%$ of average earnings on the OECD measure. To be eligible for the full benefit, 38 years (40 years in 2008 and higher thereafter) of contributions are needed; the minimum pension is pro-rated for shorter periods. Full-career workers, since the mandatory occupational pension supplements the public pension benefit, will rarely be eligible for the old-age assistance programme. The value of the minimum pension is indexed to prices. 


\section{Mandatory occupational}

The ARRCO scheme covers the majority of private-sector employees. Different rules apply to "cadres" (those in professional or managerial positions) under the AGIRC programme; the following regulations apply to non-cadres.

Although actual contributions are higher, benefits are only earned on $6 \%$ of earnings under the ceiling of the public scheme. Between one and three times the public-scheme ceiling, benefits are earned on $16 \%$ of pay. Thus, the ARRCO ceiling is three times that of the public pension scheme: EUR 89 136. (Note that there is no ceiling for the AGIRC programme for cadres.)

Each year, the number of points earned is the value of contributions divided by the cost of a pension point. At retirement, the accumulated number of points is converted into a pension benefit by multiplying by the value of a pension point. The pension-point value was EUR 1.0698 from April 2003 to April 2004 and EUR 1.0886 from April 2004, giving an annual figure for calendar 2004 of EUR 1.0839. The pension-point cost was EUR 12.362 for calendar year 2004.

Uprating of the cost and value of pension points is agreed between the social partners. The current agreement, valid until 2008, is to increase the cost of pension points in line with earnings and the value of pension points in line with prices. The modelling assumes that this differential uprating between the cost and value of a point will continue. Again, this policy of effective valorisation of earlier years' entitlements to prices results in lower benefits than valorisation to earnings. At the baseline assumptions, the reduction is to $69 \%$ of the pension entitlement under earnings valorisation.

It is important to note that the uprating policy for these two parameters affects both the path of pensions in payment (here termed "indexation") and the change in value of pension entitlements between the time they were earned and the time they are withdrawn (akin to the process of "valorisation" in earnings-related schemes).

\section{Targeted}

There is a minimum income for people aged 65 worth EUR 7053 a year. This benefit, equivalent to $24 \%$ of average earnings, is adjusted in line with earnings.

The 2003 reform introduced a new objective that, from 2008, people with a full career earning the minimum wage (corresponding to about $40 \%$ of average earnings on the OECD measure) would receive a pension equivalent to at least $85 \%$ of the net minimum wage. This has been modelled as a minimum total income guarantee of $85 \%$ of the net minimum wage for a 35-hour week. For 2004, the net minimum wage was EUR 11 086, giving a target minimum of EUR 9423 for 2004 were this policy already in place.

\section{Pre-reform scenario}

The $50 \%$ replacement-rate target of the public, earnings-related scheme has not been changed. However, the earnings measure has been extended from the best ten years and will eventually be the best 25 years. Prices valorisation of earlier years' earnings was introduced in 1987. Therefore, both pre-and post-reform scenarios assume prices valorisation. The extension of the contribution qualifying period from 37.5 to 41 years (and beyond) was explained above. Post-retirement indexation of pensions in payment has been to prices since 1998. 
Turning to the ARRCO scheme, the major change to this was in 1996. Between 1997 and 2001, the cost of a pension point was uprated in line with average earnings and the value of the pension point was uprated in line with prices. In 1996, the cost of a pension point was EUR 9.30 while in 2004, this was EUR 12.36, an increase over the period of $33 \%$. For the point value, the 1996 figure was just over EUR 0.98, rising to EUR 1.08 in calendar 2004, an increase of just $11 \%$. It is assumed for the pre-reform scenario that the relationship between the point cost and value that held in 1996 was maintained, giving a point-value for 2004 (in the absence of reform) of EUR 1.30 rather than EUR 1.08. Under the pre-reform case, it is assumed that both the cost and value of pension points was increased in line with average earnings.

\section{Early retirement}

Early retirement operates through a separate programme administered by the employment fund (FNE). Early retirement is possible from 57 and from 56 under certain circumstances related to working conditions. The replacement rate is around $80 \%$. At the normal pension age (or at the age when workers become eligible for a full regular old age pension up to 65), individuals switch to the public pension. The period on FNE benefits is fully credited for the public pension.

Under the occupational pension, early retirement is possible, often subject to reductions related either to age of retirement or years of contributions or both. Retirement is possible at age 60 with 40 years' coverage without a reduction. With fewer than 40 years' coverage, the pension is adjusted as shown in the Table with the adjustment being that which is more favourable: relating to the retirement age or to the number of missing years. For retirement at age 61 , for example, the pension is reduced to $83 \%$ of the full value. However, if the individual retires at 61 with 39 years' contributions, the reduction is only to $96 \%$, because there is only one missing year.

\begin{tabular}{lrrrrrrrrrr}
\hline Retirement age & 55 & 56 & 57 & 58 & 59 & 60 & 61 & 62 & 63 & 64 \\
Missing years & & & & & & 5 & 4 & 3 & 2 & 1 \\
Coefficient & 0.43 & 0.50 & 0.57 & 0.64 & 0.71 & 0.78 & 0.83 & 0.88 & 0.92 & 0.96 \\
\hline
\end{tabular}

\section{Late retirement}

If people work after age 60 and have reached the qualifying conditions for a full pension (which will be 40 years' coverage and increase further after 2008), each additional year increases the benefit under the public scheme by $3 \%$. For the period of deferred retirement, people continue to accumulate ARRCO points.

Work and pension receipt can be combined, provided people leave their usual job. 


\section{Pension modelling results: France}
Occupational
Earnings-related
Minimum
Minimum
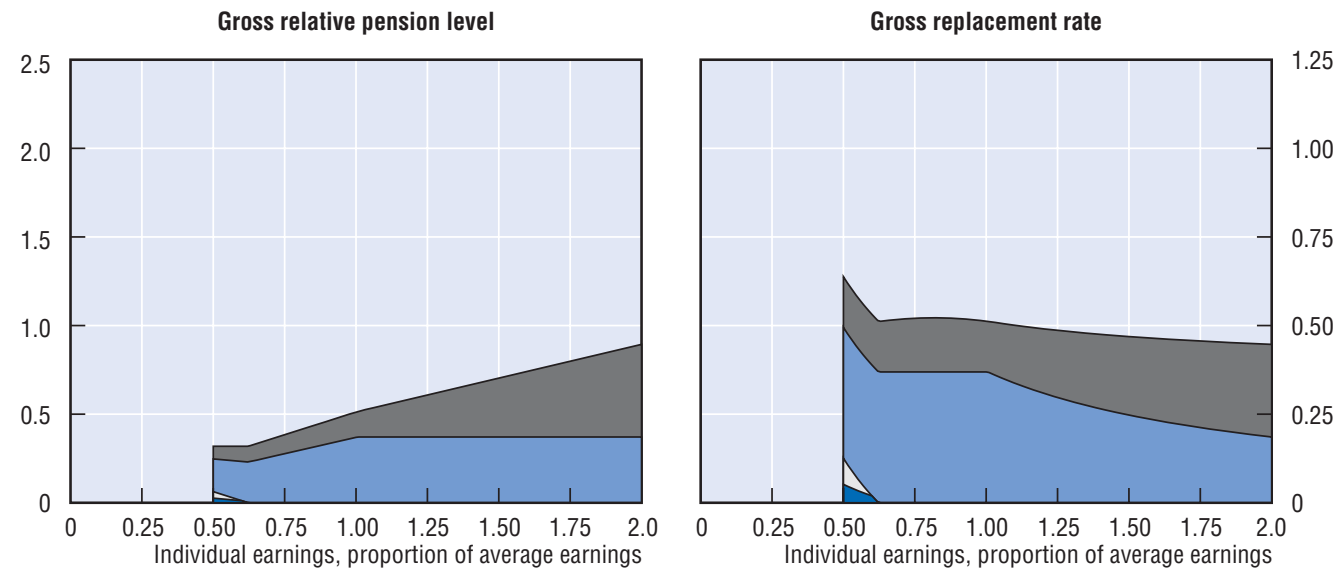

- Net

-...- Gross

Net and gross relative pension levels

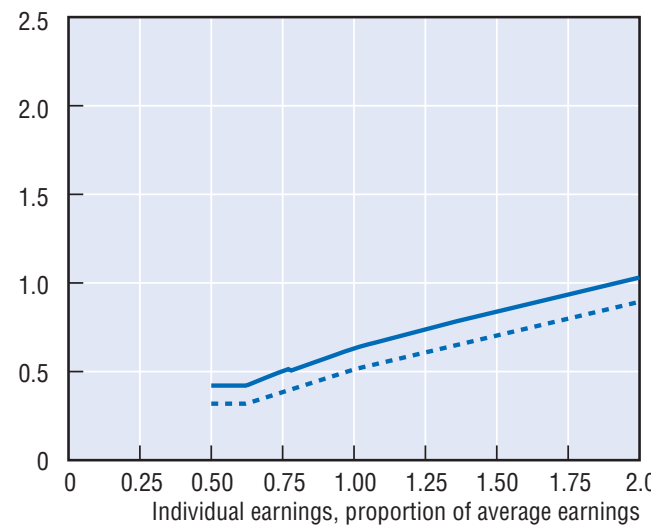

Net and gross replacement rates

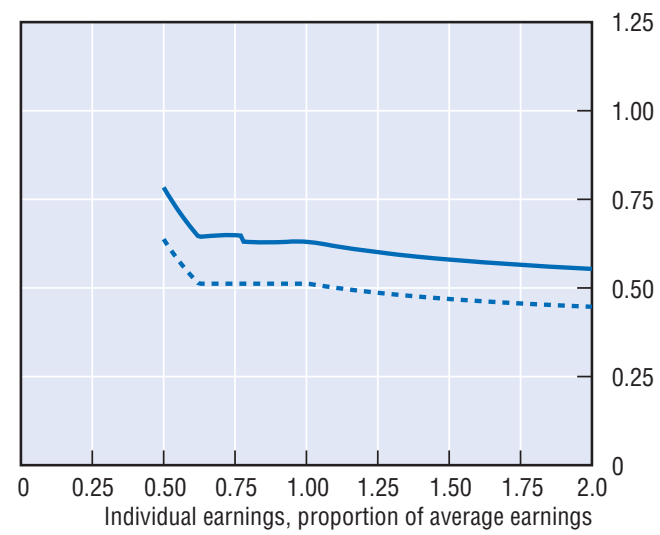

\begin{tabular}{|c|c|c|c|c|c|c|}
\hline \multirow{2}{*}{$\begin{array}{l}\text { Men } \\
\text { Women (where different) }\end{array}$} & \multirow{2}{*}{ Median earner } & \multicolumn{5}{|c|}{ Individual earnings, multiple of economy-wide average } \\
\hline & & 0.5 & 0.75 & 1 & 1.5 & 2 \\
\hline Gross relative pension level & 43.5 & 31.9 & 38.4 & 51.2 & 70.3 & 89.4 \\
\hline \multicolumn{7}{|l|}{ (\% average gross earnings) } \\
\hline Net relative pension level & 54.6 & 42.1 & 50.2 & 63.1 & 83.8 & 103.1 \\
\hline \multicolumn{7}{|l|}{ (\% net average earnings) } \\
\hline Gross replacement rate & 51.2 & 63.8 & 51.2 & 51.2 & 46.9 & 44.7 \\
\hline \multicolumn{7}{|l|}{ (\% individual gross earnings) } \\
\hline Net replacement rate & 62.8 & 78.4 & 64.9 & 63.1 & 58.0 & 55.4 \\
\hline \multicolumn{7}{|l|}{ (\% individual net earnings) } \\
\hline Gross pension wealth & 9.2 & 11.5 & 9.2 & 9.2 & 8.4 & 8.0 \\
\hline (multiple of individual gross earnings) & 10.6 & 13.2 & 10.6 & 10.6 & 9.7 & 9.3 \\
\hline Net pension wealth & 8.2 & 10.8 & 8.6 & 8.1 & 7.2 & 6.6 \\
\hline (multiple of individual gross earnings) & 9.5 & 12.4 & 9.9 & 9.3 & 8.3 & 7.6 \\
\hline
\end{tabular}


Pension modelling results: France, pre-reform scenario

\begin{tabular}{|c|c|c|c|c|c|c|}
\hline \multirow{2}{*}{$\begin{array}{l}\text { Men } \\
\text { Women (where different) }\end{array}$} & \multirow{2}{*}{ Median earner } & \multicolumn{5}{|c|}{ Individual earnings, multiple of economy-wide average } \\
\hline & & 0.5 & 0.75 & 1 & 1.5 & 2 \\
\hline Gross relative pension level & 55.0 & 32.5 & 48.5 & 64.7 & 87.7 & 110.5 \\
\hline \multicolumn{7}{|l|}{ (\% average gross earnings) } \\
\hline Net relative pension level & 67.3 & 42.8 & 60.1 & 78.1 & 101.3 & 123.9 \\
\hline \multicolumn{7}{|l|}{ (\% net average earnings) } \\
\hline Gross replacement rate & 64.7 & 64.9 & 64.7 & 64.7 & 58.4 & 55.3 \\
\hline \multicolumn{7}{|l|}{ (\% individual gross earnings) } \\
\hline Net replacement rate & 77.4 & 79.8 & 77.7 & 78.1 & 70.1 & 66.6 \\
\hline \multicolumn{7}{|l|}{ (\% individual net earnings) } \\
\hline Gross pension wealth & 11.6 & 11.7 & 11.6 & 11.6 & 10.5 & 10.0 \\
\hline (multiple of individual gross earnings) & 13.4 & 13.5 & 13.4 & 13.4 & 12.1 & 11.5 \\
\hline Net pension wealth & 10.2 & 11.0 & 10.3 & 10.0 & 8.7 & 8.0 \\
\hline (multiple of individual gross earnings) & 11.7 & 12.7 & 11.8 & 11.5 & 10.0 & 9.2 \\
\hline
\end{tabular}




\section{Germany}

$\mathrm{T}$ he statutory public pension system has a single tier and is an earnings related PAYG system. Calculation of pensions is based on pension points. There is a social-assistance safety net for low-income pensioners.

\section{Qualifying conditions}

The pension is payable from age 65 with five years' contributions and from age 63 with 35 years' for those born in 1952 and later. Fewer than five years' contributions earn no benefit.

\section{Benefit calculation}

\section{Earnings-related}

A year's contribution at the average earnings of contributors earns one pension point. The relevant average earning is approximately identical to National Accounts average earnings. Contributions based on lower or higher income earn proportionately less or more pension points. Contributions are levied on annual earnings up to EUR 61800 in 2004. The ceiling is equivalent to around $210 \%$ of the relevant average earnings. The relevant average earnings were EUR28 973 in 2004, equivalent to 70\% of the OECD average earnings measure.

At retirement, the pension points of every year are added up. The sum of pension points is multiplied by a "pension-point value", which was EUR 313.56 in calendar year 2004. The pension point value is valid for newly retired and already retired pensioners. It is uprated annually in line with gross wages as a starting point but depends on two additional factors. The first factor incorporates changes of the contribution rates to the statutory pension scheme and to the subsidised voluntary occupational and personal pension schemes. An increase of contribution rates will reduce the adjustment of pension point value. The second, so-called sustainability factor links the adjustment of the pension-point value to changes in the system dependency ratio, that is, the ratio of pensioners to contributors.

These factors were integrated into the indexation rules with the aim to limit the increase of the contribution rate from currently $19.5 \%$ to $22 \%$. The increase of the pensioner/contributor ratio will result in indexation to less than average wages. In the long run, the adjustment of the pension-point value is expected to be $18 \%$ below the increase of average earnings.

The relevant average earnings for calculating the pension points as well as the pension-point value are slightly different in the new Länder. This difference is assumed to disappear in a long run as wages will align.

\section{Social assistance}

For people with low income there is a social assistance which is also applicable for pensioners. The social-assistance amounts in the Western Länder in 2004 to EUR 7932 per year including average benefits for housing and fuel costs; this is equivalent to $19.3 \%$ of average earnings.

\section{Early retirement}

For those born 1952 or later, early retirement is possible from 63 with 35 years' contributions and eight years of contribution immediately before retirement. If retiring before the age of 65 , benefits are reduced by $3.6 \%$ per year of early retirement. In addition, 
compared to someone retiring at 65 , pension entitlement are significantly lower due to working two years less and not earning additional pension points.

\section{Late retirement}

Deferring the pension after 65 earns a $6 \%$ increment for each year of additional work.

\section{Pre-reform scenario}

For the pre-reform scenario, the modelling takes the pension-point value without adjustment for contribution increases and the sustainability factor. The pre-reform scenario allows for the tax concessions on pension income, while the baseline results assume that the transition from the old tax system to full taxation of pensions is completed.

\section{Pension modelling results: Germany}
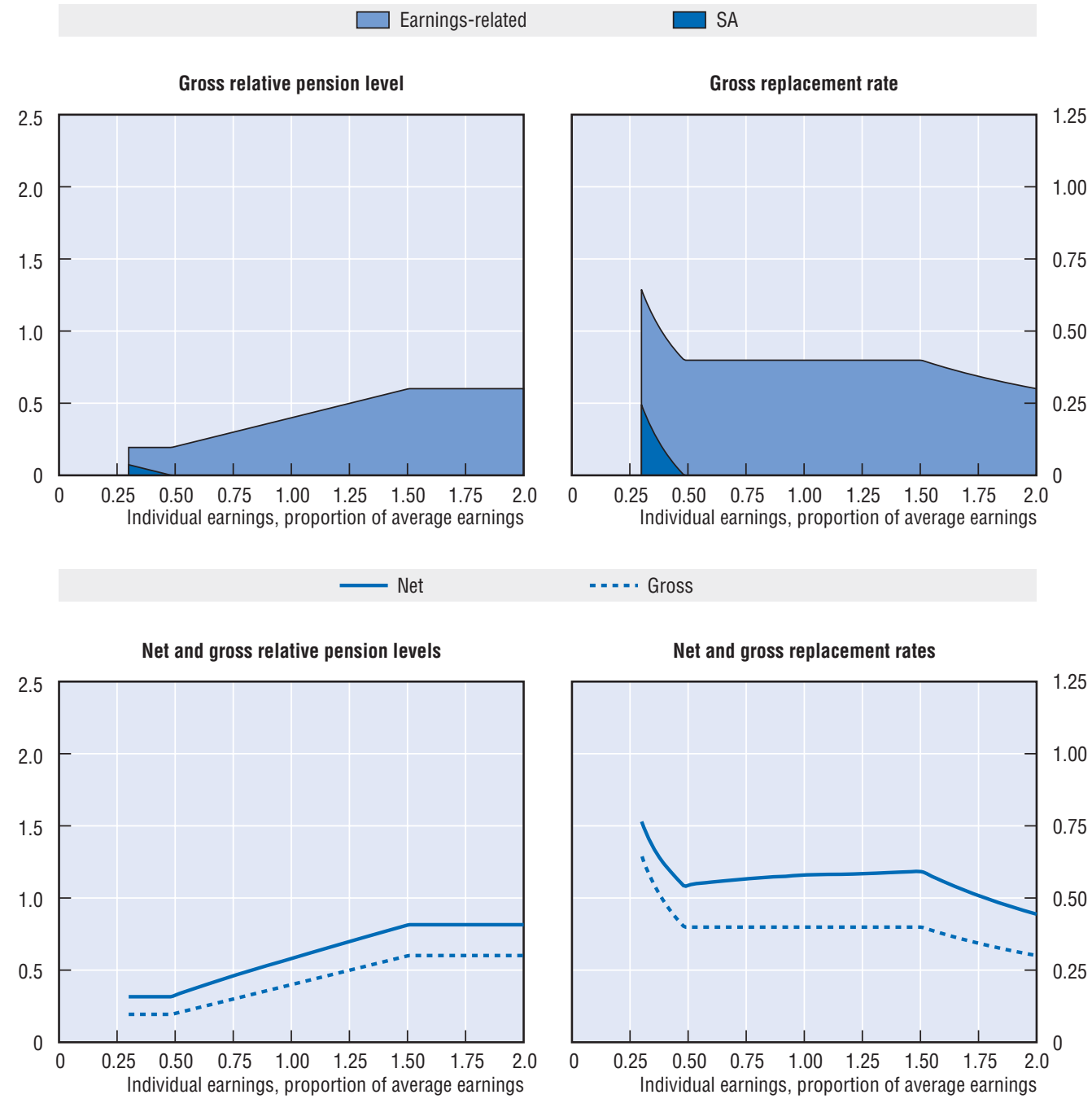


\begin{tabular}{|c|c|c|c|c|c|c|}
\hline \multirow{2}{*}{$\begin{array}{l}\text { Men } \\
\text { Women (where different) }\end{array}$} & \multirow{2}{*}{ Median earner } & \multicolumn{5}{|c|}{ Individual earnings, multiple of economy-wide average } \\
\hline & & 0.5 & 0.75 & 1 & 1.5 & 2 \\
\hline Gross relative pension level & 33.9 & 20.0 & 29.9 & 39.9 & 59.9 & 60.1 \\
\hline \multicolumn{7}{|l|}{ (\% average gross earnings) } \\
\hline Net relative pension level & 51.0 & 32.0 & 46.0 & 58.0 & 81.2 & 81.5 \\
\hline \multicolumn{7}{|l|}{ (\% net average earnings) } \\
\hline Gross replacement rate & 39.9 & 39.9 & 39.9 & 39.9 & 39.9 & 30.0 \\
\hline \multicolumn{7}{|l|}{ (\% individual gross earnings) } \\
\hline Net replacement rate & 57.3 & 53.4 & 56.6 & 58.0 & 59.2 & 44.4 \\
\hline \multicolumn{7}{|l|}{ (\% individual net earnings) } \\
\hline Gross pension wealth & 7.2 & 7.2 & 7.2 & 7.2 & 7.2 & 5.5 \\
\hline (multiple of individual gross earnings) & 8.6 & 8.6 & 8.6 & 8.6 & 8.6 & 6.5 \\
\hline Net pension wealth & 6.2 & 6.6 & 6.3 & 6.0 & 5.6 & 4.2 \\
\hline (multiple of individual gross earnings) & 7.3 & 7.8 & 7.4 & 7.0 & 6.6 & 4.9 \\
\hline
\end{tabular}

\section{Pension modelling results: Germany, pre-reform scenario}

\begin{tabular}{|c|c|c|c|c|c|c|}
\hline \multirow{2}{*}{$\begin{array}{l}\text { Men } \\
\text { Women (where different) }\end{array}$} & \multirow{2}{*}{ Median earner } & \multicolumn{5}{|c|}{ Individual earnings, multiple of economy-wide average } \\
\hline & & 0.5 & 0.75 & 1 & 1.5 & 2 \\
\hline Gross relative pension level & 41.4 & 24.4 & 36.5 & 48.7 & 73.1 & 73.3 \\
\hline \multicolumn{7}{|l|}{ (\% average gross earnings) } \\
\hline Net relative pension level & 67.5 & 39.7 & 59.6 & 79.5 & 119.2 & 119.6 \\
\hline \multicolumn{7}{|l|}{ (\% net average earnings) } \\
\hline Gross replacement rate & 48.7 & 48.7 & 48.7 & 48.7 & 48.7 & 36.7 \\
\hline \multicolumn{7}{|l|}{ (\% individual gross earnings) } \\
\hline Net replacement rate & 75.9 & 66.3 & 73.4 & 79.5 & 86.9 & 65.2 \\
\hline \multicolumn{7}{|l|}{ (\% individual net earnings) } \\
\hline Gross pension wealth & 8.8 & 8.8 & 8.8 & 8.8 & 8.8 & 6.7 \\
\hline (multiple of individual gross earnings) & 10.5 & 10.5 & 10.5 & 10.5 & 10.5 & 7.9 \\
\hline Net pension wealth & 8.2 & 8.2 & 8.2 & 8.2 & 8.2 & 6.1 \\
\hline (multiple of individual gross earnings) & 9.6 & 9.6 & 9.6 & 9.6 & 9.6 & 7.3 \\
\hline
\end{tabular}




\section{Greece}

P plus a series of minimum pensions/social safety nets. The pension system described applies to labour-market entrants from 1993.

\section{Qualifying conditions}

The normal pension age is 65 for men and 60 for women, equalised at 65 for people entering the labour force from 1993. A pension from this age requires a minimum of 4500 days of contributions (equivalent to 15 years). Workers with a contribution record of 11100 working days (37 years) can retire on a full benefit regardless of age. There are concessions for people who work in arduous or unhygienic occupations and for women with dependant or disabled children.

The minimum social pension requires 15 years' contributions.

\section{Benefit formula}

\section{Earnings-related scheme: main component}

For labour-market entrants from 1993, the pension is $2 \%$ of earnings for each year of contributions up to 35 years. There is therefore a maximum replacement rate of $70 \%$ for people retiring at the normal age or earlier. However, for working after age 65 and up to 67 , there is a higher accrual of $3 \%$ per year and there is no accrual rate for those working after 67 ( giving a maximum replacement rate of $76 \%$ ).

The maximum pension (see below) also does not apply for additional work after 65 .

The earnings measure is the average over the last five years before retirement. Earlier years' pay is adjusted in the pension value ("valorised") in line with increases defined in national incomes policy.

There is a maximum pension, calculated as four times the 1991 GNP per capita, linked to the evolution of civil servants' pensions. For 2004, this cap on pension benefits was EUR 2346.76 per month. The calculations indicate that, for a full-career worker, this is equivalent to a ceiling on pensionable earnings of $275 \%$ of average earnings.

Adjustment of pensions in payment is discretionary. In the last five years, pension increases have been progressive with one exception, when all pensions were increased by the same proportion (see below). In 1999-2001, increases of low pensions were substantially larger than price inflation. However, in 2002, they lagged behind. Given the lack of consistent practice in recent benefit adjustments, pension wealth calculations are based on price indexation.

\begin{tabular}{|c|c|c|c|c|c|c|}
\hline & 1999 & 2000 & 2001 & 2002 & 2003 & 2004 \\
\hline Inflation & $2.6 \%$ & $3.2 \%$ & $3.4 \%$ & $3.6 \%$ & $3 \%$ & $2.9 \%$ \\
\hline \multirow[t]{4}{*}{ Increases } & $3.9 \%(<$ EUR 733) & $4.0 \%$ & $5.5 \%(<$ EUR 352) & $3.5 \%(<$ EUR 400$)$ & $4 \%(<$ EUR 500$)$ & $5 \%(<$ EUR 500$)$ \\
\hline & $3.4 \%$ (> EUR 733) & & $2.75 \%$ (< EUR 587) & $1.5 \%$ (<EUR 620) & $2 \%(<$ EUR 1000$)$ & $3 \%(<$ EUR 1000$)$ \\
\hline & & & $1.4 \%$ (< EUR 880$)$ & $0.75 \%$ (<EUR 910$)$ & $0 \%(>$ EUR 1000$)$ & $0 \%(>$ EUR 1000$)$ \\
\hline & & & $0 \%$ (> EUR 880) & 0\% (> EUR 910) & & \\
\hline
\end{tabular}

All pensions have 14 monthly payments. 


\section{Earnings-related scheme: supplementary component}

The full supplementary pension is $20 \%$ of the earnings measure under the main component of the earnings-related scheme for workers with 35 years of contributions. The pension is proportionally reduced for shorter contribution periods, implying a linear accrual rate of $0.57 \%$. The value is increased by 5 th for each year of contributions (300 days) beyond 35 years.

\section{Minimum pension}

The minimum pension is set as $70 \%$ of the minimum wage for a married, full-time employee. For 2004, the value was EUR 419.48 per month, equivalent to $34 \%$ of average earnings. This value is adjusted annually as part of the incomes policy.

\section{Income-tested scheme: social solidarity benefit}

This scheme, introduced in 1996, is a non-contributory, means-tested benefit payable to low-income pensioners eligible under most schemes (apart from the farmers' pension programme).

Eligibility for benefits under this scheme, known as EKAS, requires that total net income from all sources is less than EUR 6562.02 (2004). Total taxable income must not exceed EUR 7655.71 and the total taxable family income, EUR 11 913.22.

\begin{tabular}{llllll}
\hline Income level, lower limit & 0 & EUR 5976.14 & EUR 6 210.52 & EUR 6 366.73 & EUR 6 562.02 \\
Benefit per month & EUR 141.2 & EUR 105.9 & EUR 70.6 & EUR 35.3 & 0 \\
\hline
\end{tabular}

\section{Early retirement}

Early retirement is possible subject to reductions, as shown in the table below. The adjustment is $1 / 267$ per month of early retirement, which is equivalent to $4.5 \%$ per year.

\begin{tabular}{ccl}
\hline Number of years & Eligibility age & Conditions \\
\hline 15 & 65 & No reduction \\
15 & 60 & With reduction $(1 / 267)$ \\
35 & 55 & With reduction $(1 / 267)$ \\
37 & Any & No reduction \\
\hline
\end{tabular}

\section{Late retirement}

It is possible to retire after the normal pension age of 65 . An increased accrual rate of $3 \%$ is applied in the main component up to 67 and there is no accrual rate for those working after 67 (maximum replacement rate of 76\%). After 65, maximum pension is not applied. The supplementary component also continues to accrue. It is possible to combine work and pension receipt as long as the people earn below EUR 700. 


\section{Pension modelling results: Greece}
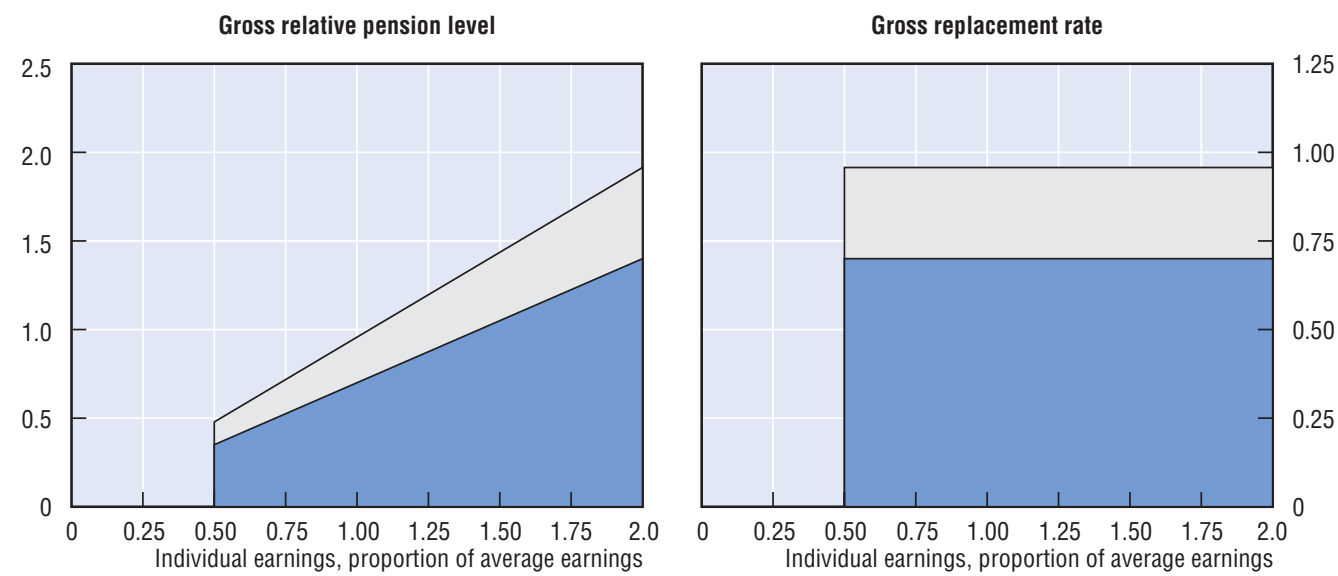

- Net

..... Gross
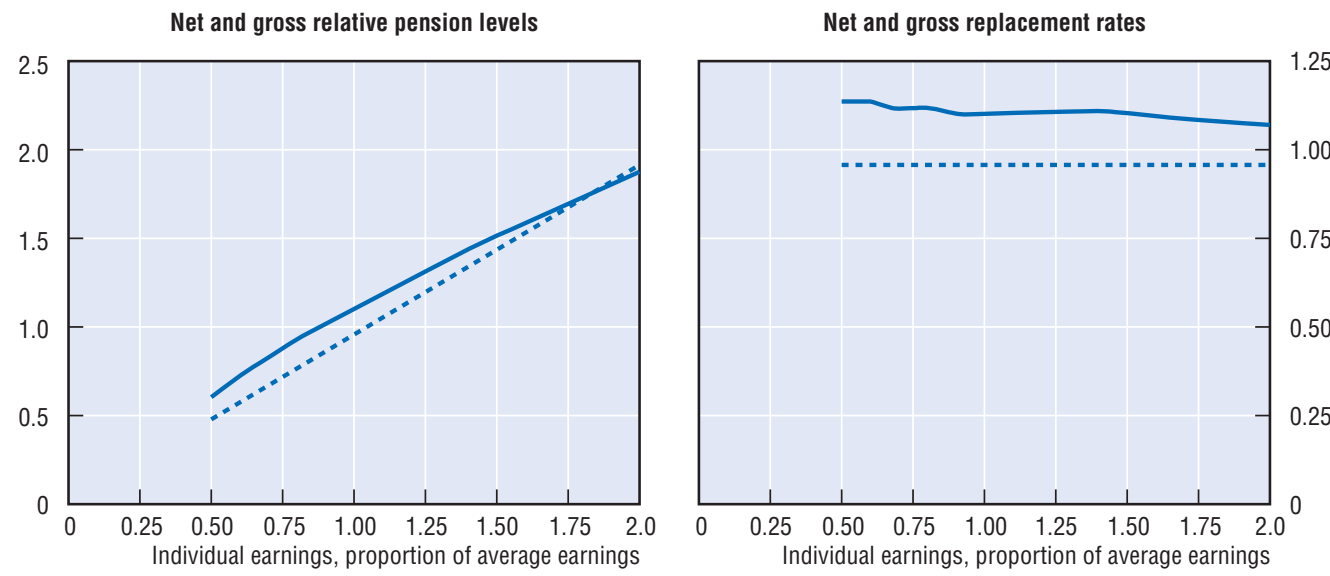

\begin{tabular}{|c|c|c|c|c|c|c|}
\hline \multirow{2}{*}{$\begin{array}{l}\text { Men } \\
\text { Women (where different) }\end{array}$} & \multirow{2}{*}{ Median earner } & \multicolumn{5}{|c|}{ Individual earnings, multiple of economy-wide average } \\
\hline & & 0.5 & 0.75 & 1 & 1.5 & 2 \\
\hline Gross relative pension level & 81.4 & 47.9 & 71.8 & 95.7 & 143.6 & 191.4 \\
\hline \multicolumn{7}{|l|}{ (\% average gross earnings) } \\
\hline Net relative pension level & 97.4 & 60.4 & 87.9 & 110.1 & 151.3 & 187.6 \\
\hline \multicolumn{7}{|l|}{ (\% net average earnings) } \\
\hline Gross replacement rate & 95.7 & 95.7 & 95.7 & 95.7 & 95.7 & 95.7 \\
\hline \multicolumn{7}{|l|}{ (\% individual gross earnings) } \\
\hline Net replacement rate & 111.1 & 113.6 & 111.7 & 110.1 & 110.3 & 107.0 \\
\hline \multicolumn{7}{|l|}{ (\% individual net earnings) } \\
\hline Gross pension wealth & 14.3 & 14.3 & 14.3 & 14.3 & 14.3 & 14.3 \\
\hline (multiple of individual gross earnings) & 16.6 & 16.6 & 16.6 & 16.6 & 16.6 & 16.6 \\
\hline Net pension wealth & 13.6 & 14.3 & 13.9 & 13.0 & 11.9 & 11.1 \\
\hline (multiple of individual gross earnings) & 15.7 & 16.5 & 16.0 & 15.1 & 13.8 & 12.8 \\
\hline
\end{tabular}




\section{Hungary}

$\mathrm{T}_{\mathrm{h}}$

he new system combines an earnings-related public pension with mandatory, funded, defined-contribution schemes. It applies to new labour-market entrants and people aged 42 or under at the time of reform. Older workers could choose between this mixed system or a pure pay-as-you-go, public pension. The modelling assumes that workers are covered by the mixed system.

\section{Qualifying conditions}

A phased increase in the pension eligibility age will equalise this at 62 for both men and women (from 60 and 55 respectively). The age for men reached 62 in 2000 and will reach 62 for women from the end of 2009. In addition, 20 years' service is required for both the earnings-related pension and the minimum pension. For those retiring before the start of 2009, 15 years' service is required to receive a partial pension.

The reformed system was introduced in June 1998. People who switched voluntarily to the new, mixed system were allowed to return to the pure pay-as-you-go system until the end of 2002. Moreover, the obligation for new entrants to join a private pension fund was suspended in calendar year 2002.

\section{Benefit calculation}

\section{Earnings-related}

For those covered by the mixed system, the accrual rate is $1.22 \%$ of earnings for each year of service (subject to the contribution ceiling, see below). This compares with an accrual rate of $1.65 \%$ for those covered by the pay-as-you-go system alone.

The earnings base is currently pay in all years since 1988, moving towards the full lifetime. Earlier years' earnings are valorised with economy-wide average earnings to a point two years before retirement. The last three years' earnings prior to retirement are entirely unvalorised.

A ceiling to pensionable earnings was introduced in 1992. In 2004, the ceiling was HUF 14500 per day. This is equivalent to 4.2 times average earnings on the OECD measure (HUF 1260 948). There have been increases in the ceiling relative to earnings since 2002.

The pension in payment has been indexed half to wages and half to prices since 2001.

There is currently an additional two weeks of pension paid each year, which will increase to an additional month's pension from 2006.

\section{Minimum}

There is a minimum pension, which was worth HUF 23200 per month in 2004 (around $16 \%$ of gross average earnings and around $25 \%$ of net average earnings). The value is indexed in the same way as benefits under the earnings-related scheme, that is, half prices and half average earnings. The minimum pension will be abolished from 2009.

\section{Defined contribution}

Some $8 \%$ of gross pensionable earnings is diverted to the funded plan from 2004 for people covered by the mixed public-private pension option (either by choice or by mandate). This represents an increase from 6\% in 2002 and 7\% in 2003. The accumulated 
capital must be converted into an annuity on retirement. The annuity must provide the same mixed indexation of the pension in payment as the public pension scheme. Unisex life tables must be used to calculate annuity rates.

\section{Early retirement}

Early retirement is currently possible for men at age 60 and at age 57 for women. When pension ages are equalised at 62, early retirement will be available from 59 for both men and women. This early-retirement age will increase to 60 from 2013.

Currently, early retirement on a full pension requires 38 years of service, which will increase to 40 years from 2009 and 41 years from 2013. A reduced pension is paid with at least 33 years of service currently, increasing to 37 years in 2009 and 38 years from 2013. The reductions follow the schedule below. The maximum reduction is therefore $30 \%$ for five missing years.

\begin{tabular}{lccccc}
\hline Missing years & 1 & 2 & 3 & 4 & 5 \\
Reduction per year of early retirement & $1.2 \%$ & $2.4 \%$ & $3.6 \%$ & $4.8 \%$ & $6.0 \%$ \\
\hline
\end{tabular}

\section{Late retirement}

It is possible to defer the earnings-related pension. The pension is increased by $0.5 \%$ for each month of deferral.

\section{Pre-reform scenario}

Before the reform, the system was based solely on an earnings-related, pay-as-you-go scheme. Benefit accrual was non-linear with the number of years of contributions. The system gave a replacement rate of $43 \%$ for 15 years of coverage, with $2 \%$ extra per year up to 25 years, $1 \%$ for the next 11 years and $1.5 \%$ for each year after that.

The pension was indexed fully to wages but is now mixed earnings/prices indexed (see above). There is a minimum pension under this system as described above. As noted above, the reform also increased the pension ages for men and women. Most elements of the reform package were legislated in 1997 and implemented in 1998.

Pensions are currently calculated based on net earnings but under the 1997 reform, the base will change to gross earnings from 2013. 


\section{Pension modelling results: Hungary}

Earnings-related

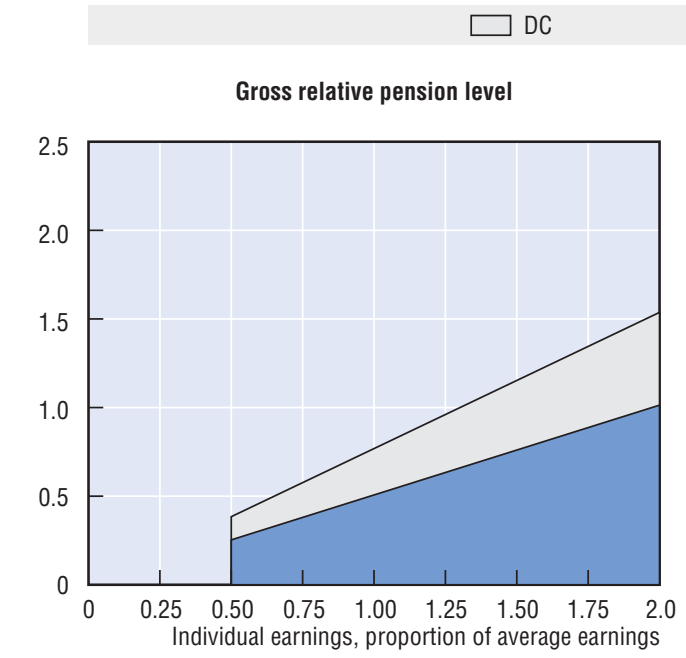

Gross relative pension level

Net

Net and gross relative pension levels

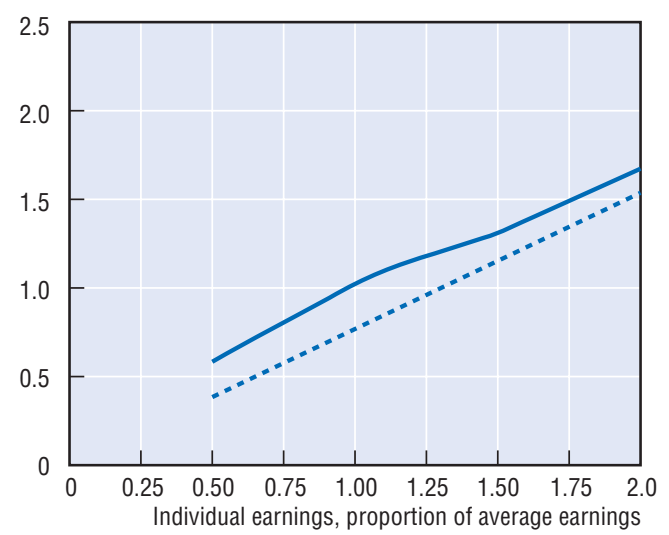

Gross replacement rate

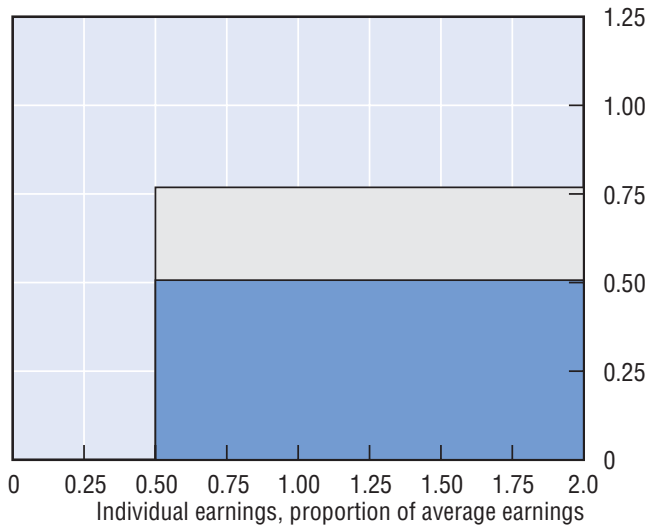

..... Gross

Net and gross replacement rates

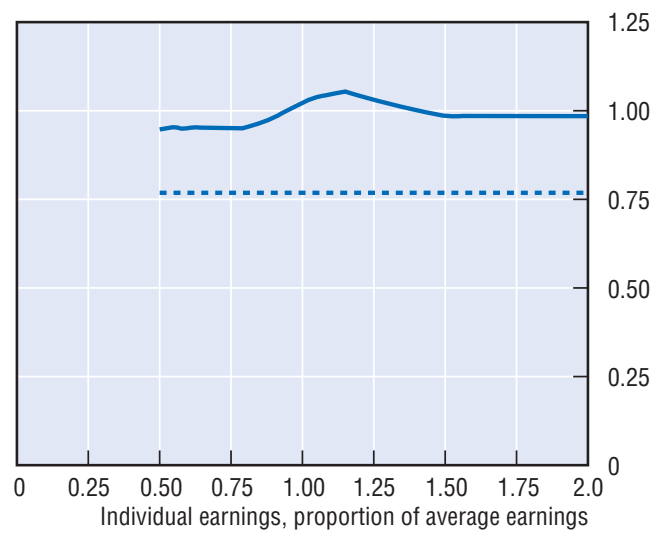

\begin{tabular}{|c|c|c|c|c|c|c|}
\hline \multirow{2}{*}{$\begin{array}{l}\text { Men } \\
\text { Women (where different) }\end{array}$} & \multirow{2}{*}{ Median earner } & \multicolumn{5}{|c|}{ Individual earnings, multiple of economy-wide average } \\
\hline & & 0.5 & 0.75 & 1 & 1.5 & 2 \\
\hline Gross relative pension level & 65.3 & 38.4 & 57.6 & 76.9 & 115.3 & 153.7 \\
\hline \multicolumn{7}{|l|}{ (\% average gross earnings) } \\
\hline Net relative pension level & 89.2 & 58.4 & 80.5 & 102.2 & 131.0 & 167.3 \\
\hline \multicolumn{7}{|l|}{ (\% net average earnings) } \\
\hline Gross replacement rate & 76.9 & 76.9 & 76.9 & 76.9 & 76.9 & 76.9 \\
\hline \multicolumn{7}{|l|}{ (\% individual gross earnings) } \\
\hline Net replacement rate & 96.5 & 94.7 & 95.1 & 102.2 & 98.5 & 98.5 \\
\hline \multicolumn{7}{|l|}{ (\% individual net earnings) } \\
\hline Gross pension wealth & 12.4 & 12.4 & 12.4 & 12.4 & 12.4 & 12.4 \\
\hline (multiple of individual gross earnings) & 15.4 & 15.4 & 15.4 & 15.4 & 15.4 & 15.4 \\
\hline Net pension wealth & 11.1 & 12.4 & 11.4 & 10.8 & 9.3 & 8.9 \\
\hline (multiple of individual gross earnings) & 13.7 & 15.3 & 14.1 & 13.4 & 11.4 & 11.0 \\
\hline
\end{tabular}


Pension modelling results: Hungary, pre-reform scenario

\begin{tabular}{|c|c|c|c|c|c|c|}
\hline \multirow{2}{*}{$\begin{array}{l}\text { Men } \\
\text { Women (where different) }\end{array}$} & \multirow{2}{*}{ Median earner } & \multicolumn{5}{|c|}{ Individual earnings, multiple of economy-wide average } \\
\hline & & 0.5 & 0.75 & 1 & 1.5 & 2 \\
\hline Gross relative pension level & 52.6 & 34.4 & 47.9 & 57.7 & 78.4 & 101.1 \\
\hline (\% average gross earnings) & 48.0 & 31.4 & 43.7 & 52.7 & 71.6 & 92.2 \\
\hline Net relative pension level & 80.3 & 52.5 & 73.1 & 88.1 & 119.6 & 154.2 \\
\hline (\% net average earnings) & 73.3 & 47.9 & 66.7 & 80.4 & 109.2 & 140.7 \\
\hline Gross replacement rate & 61.9 & 68.9 & 63.9 & 57.7 & 52.3 & 50.5 \\
\hline (\% individual gross earnings) & 56.5 & 62.8 & 58.3 & 52.7 & 47.7 & 46.1 \\
\hline Net replacement rate & 86.9 & 85.2 & 86.4 & 88.1 & 90.0 & 90.7 \\
\hline (\% individual net earnings) & 79.3 & 77.8 & 78.8 & 80.4 & 82.1 & 82.8 \\
\hline Gross pension wealth & 12.0 & 13.3 & 12.4 & 11.2 & 10.1 & 9.8 \\
\hline (multiple of individual gross earnings) & 16.2 & 18.0 & 16.7 & 15.1 & 13.7 & 13.2 \\
\hline Net pension wealth & 12.0 & 13.3 & 12.4 & 11.2 & 10.1 & 9.8 \\
\hline (multiple of individual gross earnings) & 16.2 & 18.0 & 16.7 & 15.1 & 13.7 & 13.2 \\
\hline
\end{tabular}




\section{Iceland}

$\mathrm{T}_{\mathrm{h}}$ he public pension system has three components, including a basic and two income-tested schemes. There are also mandatory occupational pensions with a hybrid (albeit mainly defined-benefit) formula.

\section{Qualifying conditions}

The normal pension age is 67 . A full basic pension is earned with 40 years' residency. The pension is proportionally reduced for shorter periods of residency, with a minimum of three years required. The pension age is also 67 for members of private-sector occupational plans.

\section{Benefit calculation}

\section{Basic}

The full basic pension value is ISK 21249 per month, equivalent to around 9\% of average earnings. This benefit is income-tested: withdrawal begins once income (from sources other than the supplementary pension) exceeds ISK 1716020 , equivalent to $62 \%$ of average earnings, and lapses at ISK 2565980 . This income test applies only to nonpension income, such as earnings from work or social assistance as well as $50 \%$ of capital income.

\section{Targeted}

A second element is the pension supplement. The maximum value of this benefit is ISK 41655 per month for a single person, some 18\% of average earnings. This benefit is withdrawn against income above ISK 550656 per year (around 20\% of average earnings). The basic pension, however, does not affect the value of the pension supplement. The withdrawal rate for the income test in the pension supplement is $45 \%$.

Finally, there is an additional pension supplement with a maximum entitlement of ISK 20540 per month, just under $9 \%$ of average earnings. This is withdrawn against all other income at a rate of two-thirds and lapses at a level of 439.680.

The benefit levels are adjusted in line with public-sector pay (which is assumed here to be equal to the standard assumption of economy-wide earnings growth).

\section{Mandatory occupational}

Employer schemes are mandatory. The law requires schemes to target a replacement rate of 56\% with 40 years' contributions, giving an accrual rate of $1.4 \%$ for each year of service. Coverage is mandatory for people aged 16 to 70 . The earnings base in this calculation is average lifetime salary for each year of membership. There is no ceiling to pensionable earnings. Past earnings are valorised in line with price inflation plus a 3.5\% interest rate.

Occupational pensions in payment must by law be increased in line with consumer price inflation.

In practice, many schemes pay more than the legal minimum outlined above, typically introducing a hybrid defined-contribution/defined-benefit element into the system. There is a minimum contribution to occupational schemes of $10 \%$ of earnings. The employee 
pays $4 \%$ and the employer $6 \%$. Contributions above the level needed to finance the statutory benefits described above can be used either to increase defined-benefit entitlements or be diverted to individual accounts thus delivering a defined-contribution pension. However, the modelling covers only the mandatory component and not these extra-statutory benefits as they are not guaranteed.

\section{Early retirement}

Under the mandatory occupational scheme, early retirement rules vary between funds, depending on the structure of fund membership. In the private sector, the normal retirement age is 67 and the pension can be claimed from 62. In general, pensions are reduced by $7 \%$ for each year that pension is claimed early.

It is not possible to claim the basic or targeted pensions before the normal pension age.

\section{Late retirement}

Under the mandatory occupational scheme, workers can postpone retirement until the age of 70 with a pension increase of $9 \%$ for each year of deferral. Workers who defer their pension continue to contribute and earn extra pension entitlements. In some cases, the total contribution period is limited to 32 years.

It is not possible to defer the basic or targeted pension after normal pension age. The basic pension is subject to an earnings test (see above), while the targeted schemes are tested against all income, including earnings. 


\section{Pension modelling results: Iceland}

Occupational

Gross relative pension level

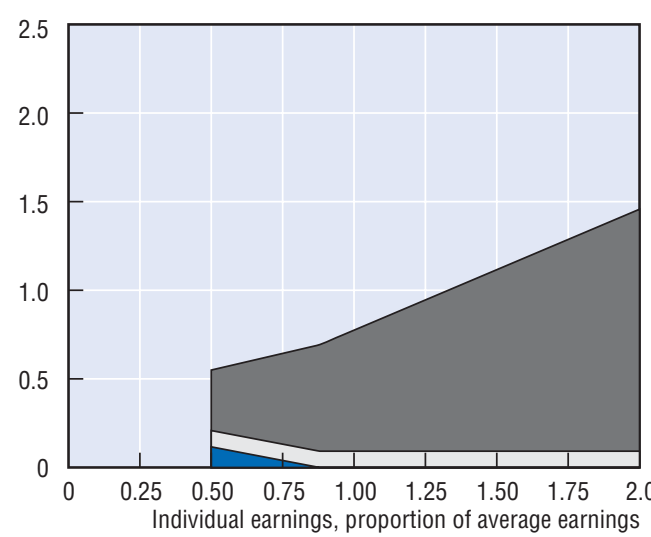

Net

Net and gross relative pension levels

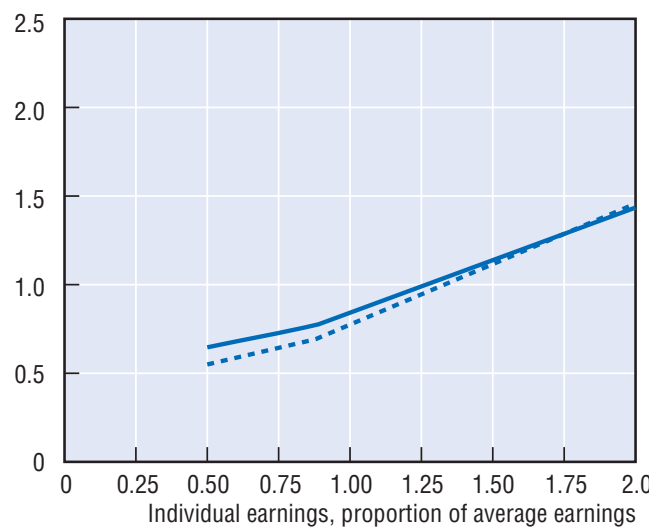

Gross replacement rate

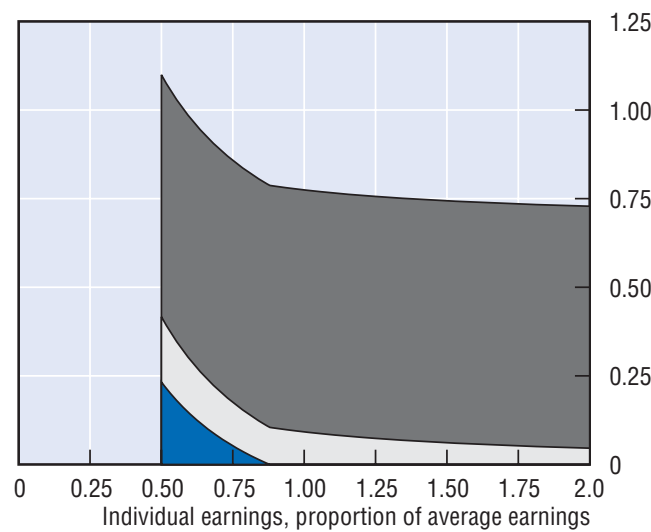

.... - Gross

Net and gross replacement rates

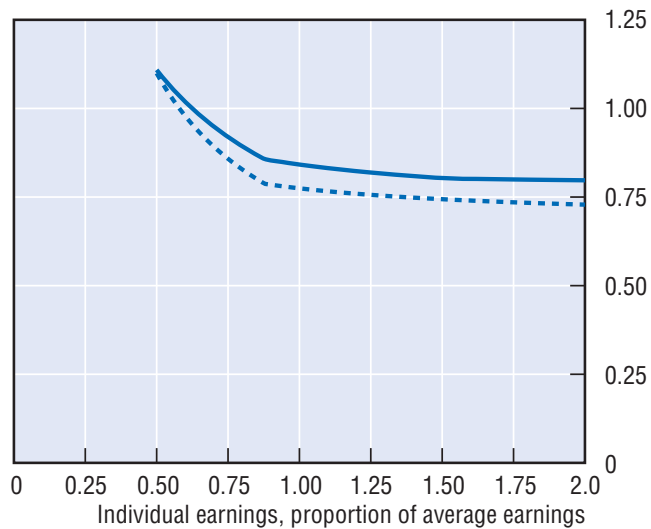

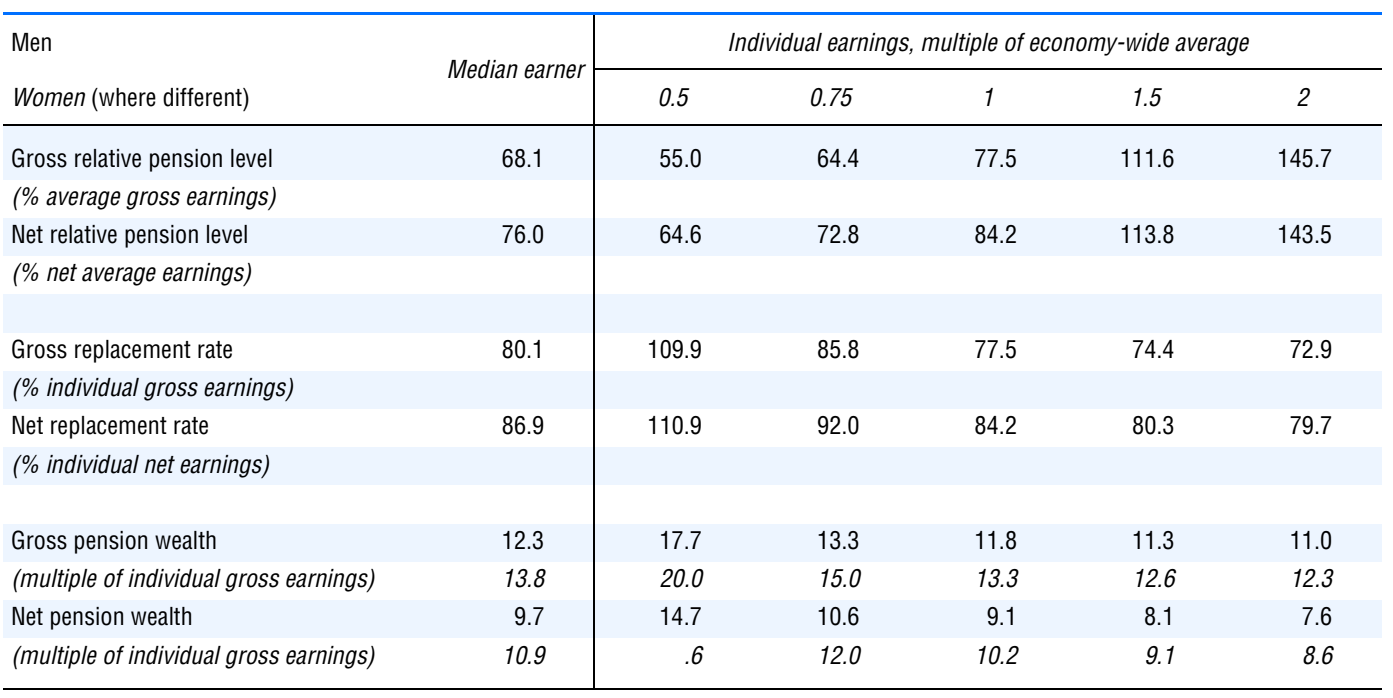




\section{Ireland}

$\mathrm{T}$ he public pension is a basic scheme paying a flat rate to all who meet the contribution conditions. There is also a means-tested pension to provide a safety net for the low-income elderly. Voluntary occupational pension schemes have broad coverage: around half of employees.

\section{Qualifying conditions}

The old-age contributory pension is payable from age 66 while the retirement pension is paid from 65. Full entitlement to both benefits requires an average of 48 weeks contributions or credits per year throughout the working life. The pension value is proportionally reduced for incomplete contribution histories. However, the old-age contributory pension requires a minimum average of ten weeks' contributions per year and the retirement pension 24 weeks per year. There is also a minimum total period of contributions of 260 weeks (equivalent to five years' full coverage).

The means-tested pension is payable from age 66.

\section{Benefit calculation}

\section{Basic}

The values of the old-age contributory pension and the retirement pension are both EUR 167.30 per week (paid for 53 weeks per year) for 2004, which is around 30\% of average earnings (on the OECD measure of average earnings). There is an addition of EUR 111.50 for a dependent adult of working age and EUR 129.20 for a dependant aged 66 or over. The value of the basic pension under a recent long-term plan is fixed relative to earnings: the national target is $34 \%$ of the previous year's average industrial earnings.

Pensioners are entitled to many benefits-in-kind. The government estimates that the price of these goods and services would be EUR 870 per year, excluding health benefits. (Note that the modelling covers only cash benefits and not benefits-in-kind.)

\section{Targeted}

The maximum value of the means-tested benefit is EUR 154 per week for a single person with an extra EUR 101.80 for an adult dependant for 2004. The single person's benefit is worth $27 \%$ of average earnings. There is a small disregard in the means test: otherwise, the benefit is withdrawn at $100 \%$ of income. There is also an assets test, with capital of more than EUR 20315 being converted to income using a standard formula.

The value of the target safety-net income in the means-tested scheme broadly follows the uprating of the basic schemes (i.e., linked to earnings).

\section{Early retirement}

Pensions can not be claimed before the normal eligibility age.

\section{Late retirement}

Work and pension can be combined subject to earnings being less than EUR 38 per week (under the retirement pension). However, the old-age contributory pension is not subject to an earnings test. It is not possible to defer claiming the pension. 


\section{Pension modelling results: Ireland}

$\square$ Basic

Gross relative pension level

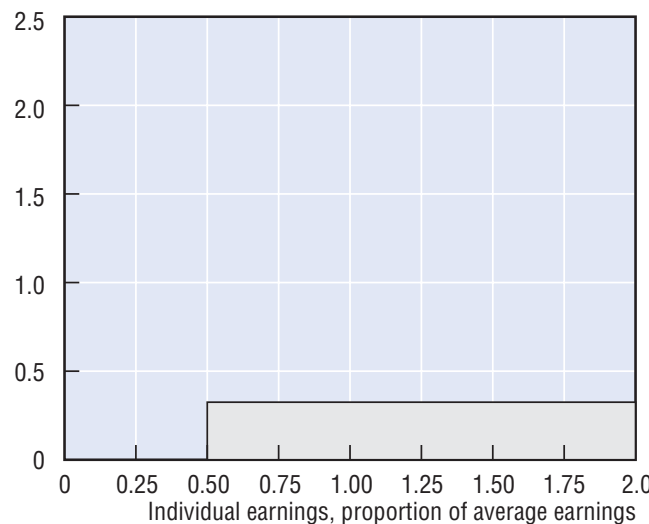

Net

Net and gross relative pension levels

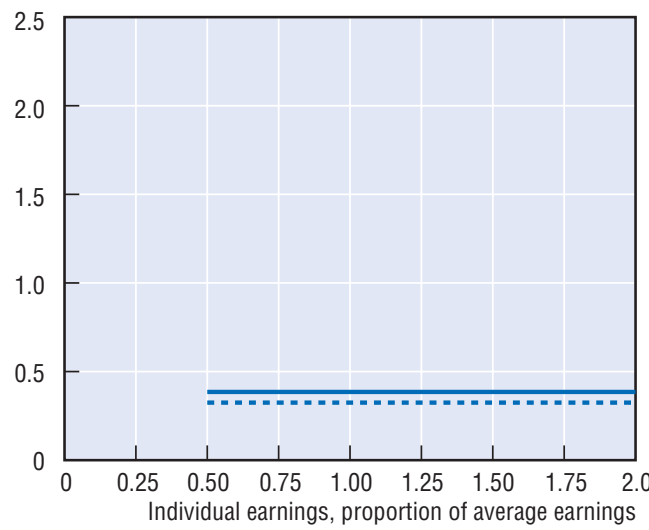

Gross replacement rate

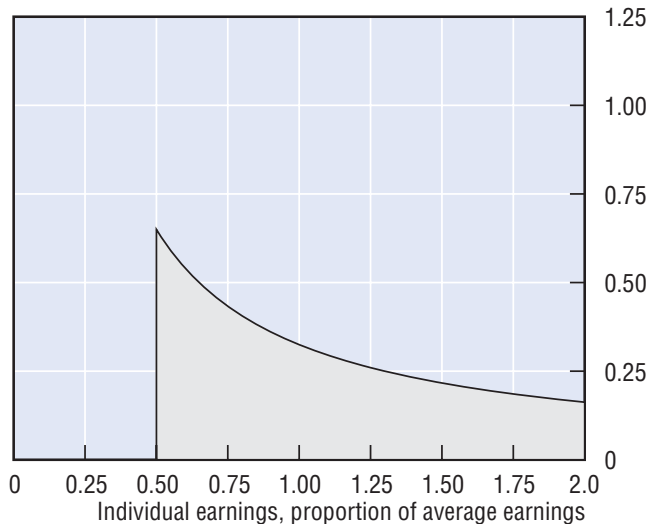

..... Gross

Net and gross replacement rates

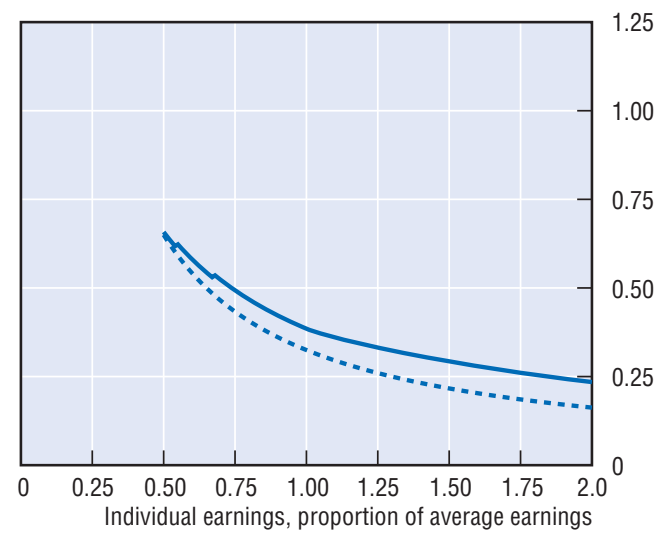

\begin{tabular}{|c|c|c|c|c|c|c|}
\hline \multirow{2}{*}{$\begin{array}{l}\text { Men } \\
\text { Women (where different) }\end{array}$} & \multirow{2}{*}{ Median earner } & \multicolumn{5}{|c|}{ Individual earnings, multiple of economy-wide average } \\
\hline & & 0.5 & 0.75 & 1 & 1.5 & 2 \\
\hline Gross relative pension level & 32.5 & 32.5 & 32.5 & 32.5 & 32.5 & 32.5 \\
\hline \multicolumn{7}{|l|}{ (\% average gross earnings) } \\
\hline Net relative pension level & 38.5 & 38.5 & 38.5 & 38.5 & 38.5 & 38.5 \\
\hline \multicolumn{7}{|l|}{ (\% net average earnings) } \\
\hline Gross replacement rate & 38.2 & 65.0 & 43.3 & 32.5 & 21.7 & 16.2 \\
\hline \multicolumn{7}{|l|}{ (\% individual gross earnings) } \\
\hline Net replacement rate & 44.4 & 65.8 & 49.3 & 38.5 & 29.3 & 23.5 \\
\hline \multicolumn{7}{|l|}{ (\% individual net earnings) } \\
\hline Gross pension wealth & 6.8 & 11.5 & 7.7 & 5.8 & 3.8 & 2.9 \\
\hline (multiple of individual gross earnings) & 8.1 & 13.7 & 9.2 & 6.9 & 4.6 & 3.4 \\
\hline Net pension wealth & 6.8 & 11.5 & 7.7 & 5.8 & 3.8 & 2.9 \\
\hline (multiple of individual gross earnings) & 8.1 & 13.7 & 9.2 & 6.9 & 4.6 & 3.4 \\
\hline
\end{tabular}




\section{Italy}

$\mathrm{T}_{\mathrm{h}}$ he new Italian pension system is based on notional accounts. Contributions earn a rate of return related to GDP growth. At retirement, the accumulated notional capital is converted into an annuity taking account of average life expectancy at retirement. It applies in full to labour-market entrants from 1996 onwards.

\section{Qualifying conditions}

As a result of the 2004 pension reform, the normal pension age under the new system will be 60 for women and 65 for men from 2008 onwards. However, early retirement will still be possible under various contribution conditions (see below). The baseline modelling assumes that men retire at 65 and women at 60 . $^{*}$

\section{Benefit calculation}

\section{Earnings-related}

Under the notional-account scheme, employees are credited with $33 \%$ of earnings, which is slightly above the actual contribution rates paid by employees and employers. Contributions are then uprated in line with a five-year moving average of GDP growth until the year of retirement. The baseline assumption in modelling all countries is $2 \%$ annual real wage growth. Given the projected decline in the Italian labour force, a consistent assumption is that real GDP growth is $1.6 \%$ per year.

The resulting notional capital is multiplied by a "transformation coefficient" at retirement. The coefficient varies with the age at which the pension is claimed. The values are supposed to be reviewed every ten years based on evidence of mortality rates at different ages. Social partners and parliament are consulted but final responsibility rests with government. The calculations assume a real interest rate of $1.5 \%$. Actuarial illustrations for 2036-45 (which includes 2040, the year used for the baseline projections) based on ISTAT 2001 demographic forecasts are:

\begin{tabular}{lccccccccc}
\hline Age of retirement & 57 & 58 & 59 & 60 & 61 & 62 & 63 & 64 & $65+$ \\
Transformation coefficient (\%) & 4.014 & 4.113 & 4.217 & 4.328 & 4.446 & 4.572 & 4.705 & 4.847 & 4.999 \\
\hline
\end{tabular}

For employees, minimum pay for contribution purposes is EUR 164.87 per week (39\% of average earnings). Maximum earnings for benefits are EUR 82401 per year under the new scheme, or just over $370 \%$ of average earnings.

The indexation of pensions in payment is complex, since smaller pensions are accorded a more generous treatment than larger pensions. For benefits up to three times the minimum pension, there is full price indexation of pensions in payment. This threshold is EUR 1206 per month for 2003 (which is used to index pensions in 2004) and EUR 1236 for 2004 (for 2005 indexation) or approximately two-thirds of economy-wide average earnings. For benefits between three and five times the minimum pension, pensions in payment are

\footnotetext{
* Italy has expressed serious doubts about the adequacy of data used in the report, and consequently about the comparability of results. In particular, baseline assumptions about labour market entry ages and career length (respectively, 20 and 45 years) are different from those agreed in a comparable exercise undertaken at the EU level, and differ from current Italian labour market norms. Italy thinks interpretations based on these data may be misleading.
} 
uprated by $90 \%$ of price inflation. Above this threshold, indexation falls to $75 \%$ of prices. Note that the indexation applies separately to each slice of a large pension.

\section{Social assistance}

The minimum pension (see below) is abolished for people covered only under the new system; i.e., entrants after 1996. However, pensioners with incomes below the social-assistance level can claim a means-tested benefit from age 65. Including supplements, the 2004 value of the social-assistance benefit (assegno sociale) was EUR 4 952. There is a higher benefit of EUR 6967 for over 70s. These are equivalent to 22\% and 31\% of average earnings, respectively.

\section{Early retirement}

The 2004 pension reform set normal pension ages under the new system at 65 for men and 60 for women from 2008. This is the same normal pension age as in the old system. Men with at least 35 years of contributions will be able to retire from age 60 (as of 2008). The minimum retirement age for men will subsequently increase to 61 from 2010 and 62 from 2014. There is a further nine-month (on average, as of 2008) waiting period for early retirement with fewer than 40 years' coverage, giving effective early retirement ages 9 months higher than those quoted. Women will remain able to draw a pension from age 57 until 2015. From 2016, women cannot retire before age 60.

However, it will remain possible to retire at any age with 40 years' contributions. Finally, taking any early retirement requires that the pension is worth at least 1.2 times the social-assistance pension.

\section{Late retirement}

Women have the right to continue working until the normal pension age for men. Retirement is not compulsory at 65 but employers have the right to dismiss employees reaching that age. Under the notional-account scheme, it is not possible to combine employment and pension receipt until age 63. After age 63, it is possible but there is a penalty: the tax rate on earnings is $50 \%$ on income above the minimum pension until the total tax is equal to the entire pension.

It is possible to defer the pension claim after age 65 , however the transformation coefficient (see above) remains the same, and benefits increase only because of the accumulation of further contributions and their (notional) capitalisation for one or more further years.

\section{Pre-reform scenario}

New labour-market entrants from 1996 onwards are covered solely by the new system. People with more than 18 years contributions at the time of the reform are covered only by the old system. The cohorts in between have their accrued rights up to the end of 1995 covered by the old system and subsequent rights under the new system.

The old system was a defined-benefit scheme paying a variable proportion of earnings for each year of contributions. For years of work after 1993, a schedule applied to different bands of earnings. This is the schedule for 2004:

\begin{tabular}{lccccc}
\hline Band (lower limit) & 0 & EUR 37884 & EUR 50386 & EUR 62887 & EUR 71 980 \\
Accrual rate & $2.0 \%$ & $1.6 \%$ & $1.35 \%$ & $1.10 \%$ & $0.9 \%$ \\
\hline
\end{tabular}

There was no ceiling to earnings covered in the old system. 
Normal pension age under this scheme was increased gradually from 1992 (60 for men, 55 for women) to reach 65 for men and 60 for women from 2000 onwards. Pension receipt requires 20 years of contributions (15 years until 1992).

However, there was also a "seniority pension" (pensione di anzianità) that enabled earlier receipt of pension. The 1992 reform gradually tightened these requirements. Thus, people can retire at any age with 37 years' contribution in 2001-03, 38 years in 2004/05, 39 years in 2006/07 and 40 years from 2008 onwards. With 35 years' contributions, the pension could be drawn at 56 in 2001 increasing to 57 from 2002. Further increases are envisaged, as set out below.

The minimum pension is set at EUR 50 per month higher than the social-assistance benefit (described above) for 60-64-year-olds and EUR 110 higher for 65-69-year-olds. From age 70, the minimum pension is the same as the social-assistance benefit.

Under the old system, it was possible to combine work and pensions after age 58 conditional on 37 years of contributions.

\section{Pension modelling results: Italy}

Earnings-related
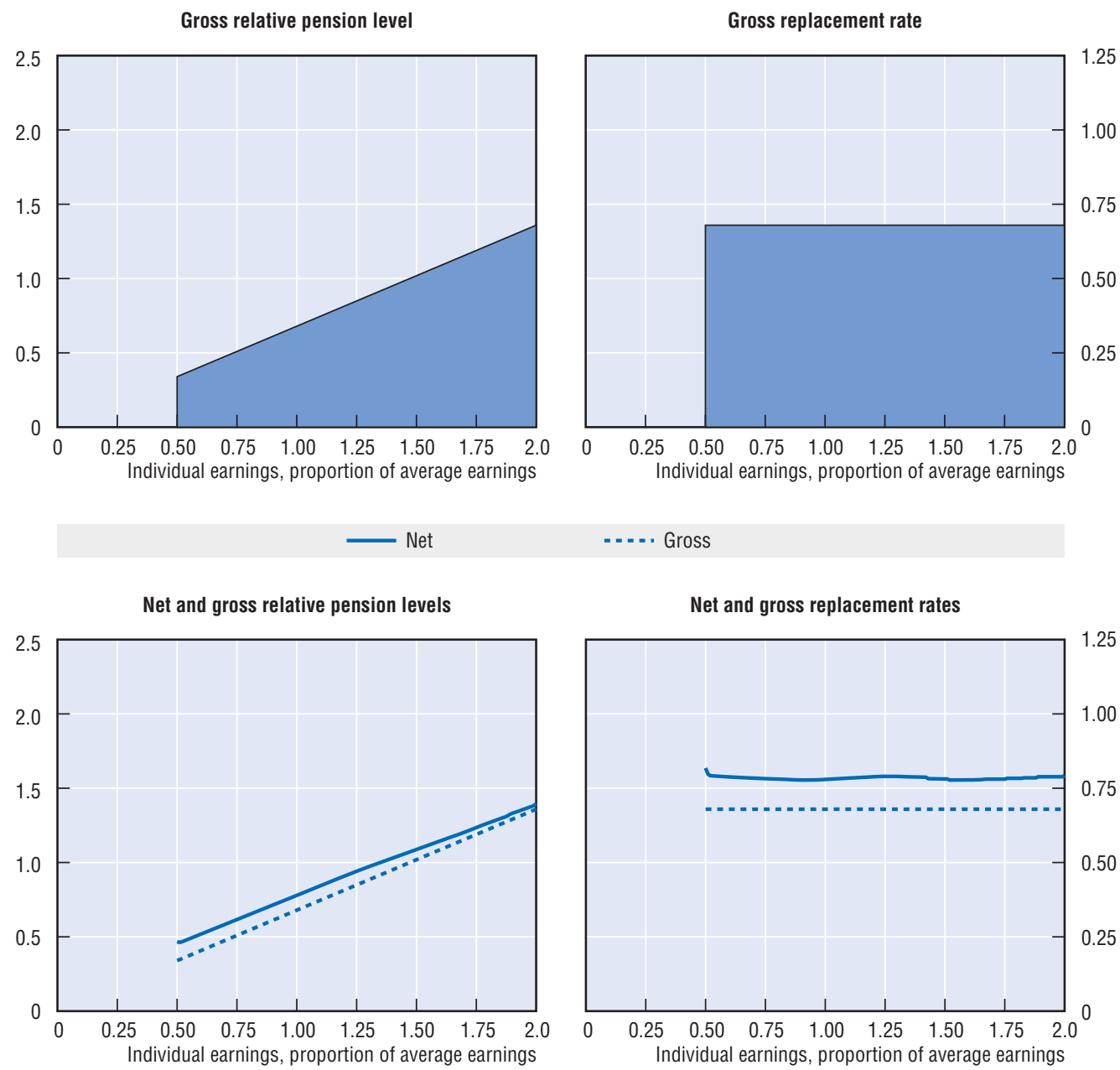


\begin{tabular}{|c|c|c|c|c|c|c|}
\hline \multirow{2}{*}{$\begin{array}{l}\text { Men } \\
\text { Women (where different) }\end{array}$} & \multirow{2}{*}{ Median earner } & \multicolumn{5}{|c|}{ Individual earnings, multiple of economy-wide average } \\
\hline & & 0.5 & 0.75 & 1 & 1.5 & 2 \\
\hline (\% average gross earnings) & 44.9 & 26.4 & 39.6 & 52.8 & 79.2 & 105.6 \\
\hline Net relative pension level & 68.1 & 46.7 & 61.6 & 77.9 & 108.8 & 139.6 \\
\hline Gross replacement rate & 67.9 & 67.9 & 67.9 & 67.9 & 67.9 & 67.9 \\
\hline (\% individual gross earnings) & 52.8 & 52.8 & 52.8 & 52.8 & 52.8 & 52.8 \\
\hline Net replacement rate & 77.9 & 81.8 & 78.2 & 77.9 & 78.1 & 79.3 \\
\hline (\% individual net earnings) & 63.8 & 63.6 & 64.4 & 63.4 & 63.7 & 63.5 \\
\hline Net pension wealth & 8.6 & 10.0 & 8.8 & 8.4 & 7.7 & 7.4 \\
\hline (multiple of individual gross earnings) & 9.7 & 10.7 & 10.0 & 9.4 & 8.7 & 8.2 \\
\hline
\end{tabular}

Pension modelling results: Italy, pre-reform scenario

\begin{tabular}{|c|c|c|c|c|c|c|}
\hline \multirow{2}{*}{$\begin{array}{l}\text { Men } \\
\text { Women (where different) }\end{array}$} & \multirow{2}{*}{ Median earner } & \multicolumn{5}{|c|}{ Individual earnings, multiple of economy-wide average } \\
\hline & & 0.5 & 0.75 & 1 & 1.5 & 2 \\
\hline Gross relative pension level & 76.5 & 45.0 & 67.5 & 90.0 & 135.0 & 174.9 \\
\hline (\% average gross earnings) & 68.0 & 40.0 & 60.0 & 80.0 & 120.0 & 155.5 \\
\hline Net relative pension level & 86.1 & 55.9 & 77.5 & 98.6 & 138.1 & 170.8 \\
\hline (\% net average earnings) & 78.0 & 51.1 & 70.3 & 89.5 & 124.7 & 155.1 \\
\hline Gross replacement rate & 90.0 & 90.0 & 90.0 & 90.0 & 90.0 & 87.5 \\
\hline (\% individual gross earnings) & 80.0 & 80.0 & 80.0 & 80.0 & 80.0 & 77.7 \\
\hline Net replacement rate & 98.5 & 97.8 & 98.4 & 98.6 & 99.2 & 97.0 \\
\hline (\% individual net earnings) & 89.2 & 89.5 & 89.2 & 89.5 & 89.5 & 88.1 \\
\hline Gross pension wealth & 13.3 & 13.3 & 13.3 & 13.3 & 13.3 & 12.9 \\
\hline (multiple of individual gross earnings) & 16.3 & 16.3 & 16.3 & 16.3 & 16.3 & 15.8 \\
\hline Net pension wealth & 10.9 & 12.0 & 11.1 & 10.6 & 9.9 & 9.2 \\
\hline (multiple of individual gross earnings) & 13.6 & 15.1 & 13.8 & 13.2 & 12.3 & 11.5 \\
\hline
\end{tabular}




\section{Japan}

$\mathrm{T}$ he public pension system has two tiers: a basic, flat-rate scheme and an earningsrelated plan (employees' pension scheme).

\section{Qualifying conditions}

The old-age, basic pension is paid from age 65 with a minimum of 25 years' contributions. The full basic pension requires 40 years of contributions, with benefits adjusted proportionally for shorter or longer contribution periods.

The earnings-related pension is paid in addition to basic pension, with a minimum of one month's contribution, provided a pensioner is entitled to the basic pension. The pension age is gradually being increased from 60 to 65 years (between 2001 and 2013 for men and between 2006 and 2018 for women) for the flat-rate component and from 60 to reach 65 years for men in 2025 and for women in 2030 for the earnings-related component. The earningsrelated component of the employees' pension scheme is adjusted for shorter or longer contribution periods.

\section{Benefit calculation}

\section{Basic}

The full basic pension for 2004 was JPY 794500 per year, corresponding to $16 \%$ of average earnings. The basic pension is price indexed.

\section{Earnings-related}

The employees' pension scheme has a flat-rate and an earnings-related component, of which the earnings-related part is by far the most important. The accrual rate was $0.75 \%$ of earnings excluding bonuses until fiscal year 2002. From fiscal year 2003, the base for calculating pension was extended to include bonuses. With the extension of the base for calculating the pension, the accrual rate has been reduced to $0.5481 \%$ of earnings (including bonuses).

Earlier years' earnings are valorised in line with economy-wide average net earnings.

There is a ceiling on earnings subject to contributions of JPY 620000 a month equivalent to $150 \%$ of average earnings.

The flat-rate benefit depends on year of birth. In 2004, it ranged between JPY 1676 and JPY 3143 per month of contributions. This is paid only to pensioners between 62 and 64 years and this benefit will be phased out by 2013 .

The employees' pension in payment is price indexed.

\section{Contracting out}

Employers who have at least 1000 employees, may "contract out" of a portion of the earnings-related pension (known as the "substitution part") if they cover their employees themselves; around 15\% of employees participate in these schemes. Contracting-out requires that employers offer at least $150 \%$ (before 2005 : 110\%) of the benefit that the public earnings-related scheme would have provided. The calculation of the pension required for contracting out is based on lifetime average nominal earnings. Indexation of pensions in payment and valorisation of past earnings is financed by the government. 
The contribution rate in contracted-out schemes is determined by the government depending on the age structure of the covered employees and actuarial assumptions. Until 1996, however, the rate was uniform across plans. Since 2005, the rate ranges between $2.4 \%$ and $5 \%$ of total remuneration.

Since 2001, the government has also been promoting DC pension schemes and DB occupational pension schemes. As a consequence, several employees' pension funds have been dissolved.

\section{Early retirement}

Until 2001, a "specially provided" employees' pension was available at age 60 . This is being phased out and retirement with a full benefit will not be possible before age 65 .

Early retirement at a reduced benefit is possible in both the basic and earnings-related schemes. The benefit is reduced by $0.5 \%$ per month of early retirement, i.e. $6 \%$ per year. Individuals can claim the flat-rate component of the employees' pension between 60 and 65 . The pension in payment is indexed to net average earnings until the pensioner reaches age 65 and price-indexed after age 65 .

\section{Late retirement}

It is possible to defer receipt of the basic and earnings-related pensions. Deferral increases the pension benefit by $0.7 \%$ per month, i.e. $8.4 \%$ per year. Pension rights continue to accrue for each year of contributions beyond 65 .

From 2006, combining work and pension after age 65 will be possible provided total income (from earnings and pension) does not exceed JPY 480 000. Above this limit, half of the excess is reduced from the full earnings-related pension payment but basic pension is paid in full. From April 2007, the reduction will also apply to the workers over 70 but they do not need to pay contributions.

\section{Pre-reform scenario}

In 1994, the increase in pension age (as set out above) for the flat-rate component of the employees' pension scheme was introduced. The rate of growth of gross earnings was formerly used for valorisation while the current system uses net earnings. In 2000, the pension age in the earnings-related component was increased. The base for contribution was extended to include the bonus and the contribution rate for the earnings-related scheme was reduced.

The most recent reform took place in 2004. The contribution rate will be fixed after 2017 at $18.3 \%$ for the earnings-related scheme while the contribution for the basic scheme will be fixed at JPY 16900 plus inflation.

This reform also introduced a link to projected changes in life expectancy risk into the benefit formula. For about 20 years, until the moment when pension revenues are equal to expenditures, a special adjustment factor will be used for valorisation. This factor is calculated as the sum of the average decrease of the number of contributors in the public pension schemes over three years and the growth rate of life expectancy. The latter is assumed to grow at a constant rate of $0.3 \%$. The factor is subtracted from the net earnings growth (for valorisation) and from price inflation (for indexation), but some ratchets are built in to prevent negative valorisation and indexation. The target minimum replacement rate for a single-earner couple at average earnings with 40 years of contributions is $50 \%$. 
If the replacement rate falls below $50 \%$ as a result of the adjustment, the mechanism will be suspended and further measures will be introduced to ensure the level of the replacement rate. According to government estimates the adjustment factor will be $0.9 \%$ until 2025. Afterwards, the system will return to valorisation to net earnings and inflation indexation.

\section{Pension modelling results: Japan}

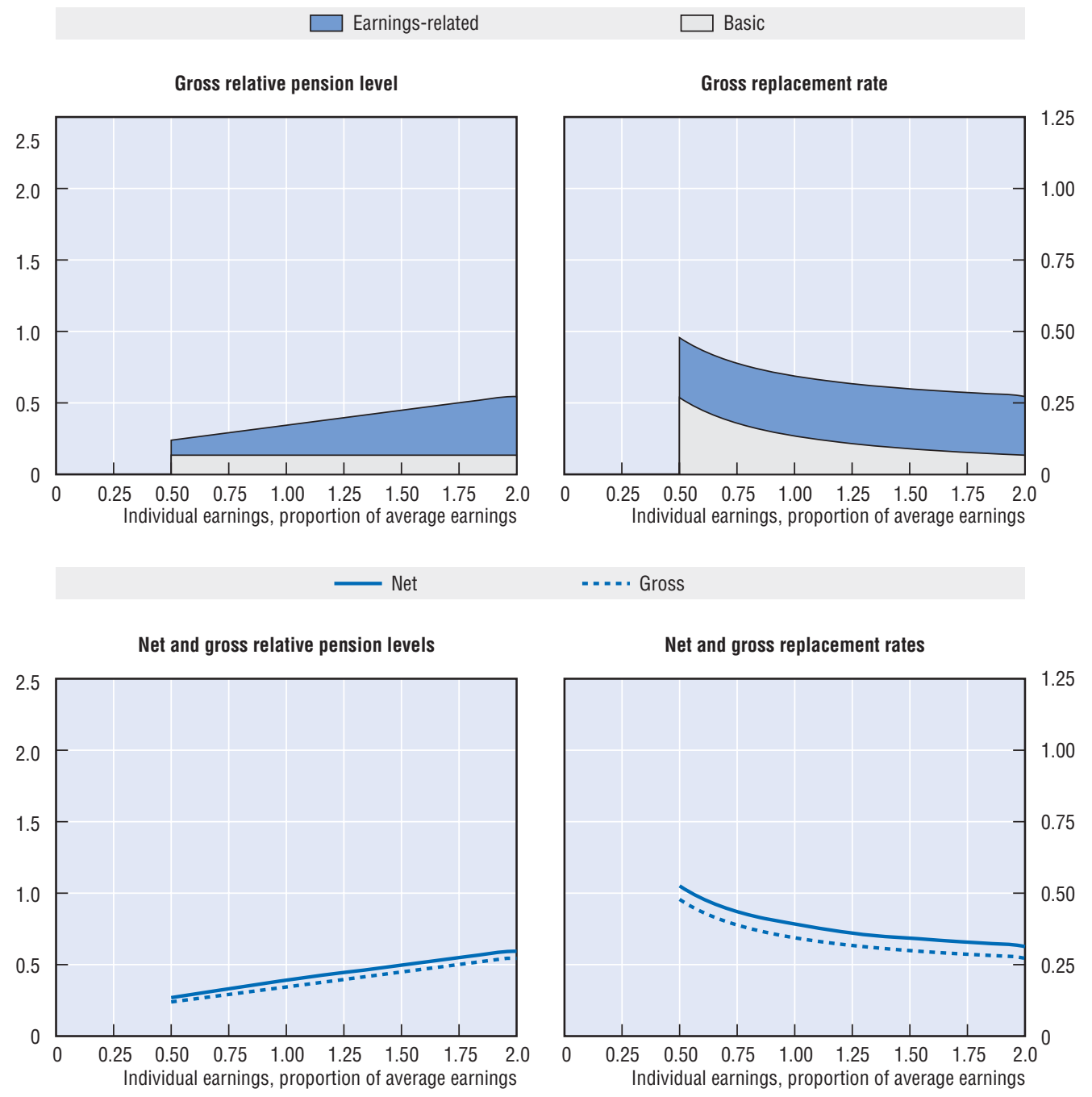




\begin{tabular}{|c|c|c|c|c|c|c|}
\hline \multirow{2}{*}{$\begin{array}{l}\text { Men } \\
\text { Women (where different) }\end{array}$} & \multirow{2}{*}{ Median earner } & \multicolumn{5}{|c|}{ Individual earnings, multiple of economy-wide average } \\
\hline & & 0.5 & 0.75 & 1 & 1.5 & 2 \\
\hline \multicolumn{7}{|l|}{ (\% average gross earnings) } \\
\hline Net relative pension level & 35.6 & 26.9 & 33.1 & 39.2 & 49.6 & 59.3 \\
\hline \multicolumn{7}{|l|}{ (\% net average earnings) } \\
\hline Gross replacement rate & 36.8 & 47.8 & 38.9 & 34.4 & 29.9 & 27.2 \\
\hline \multicolumn{7}{|l|}{ (\% individual gross earnings) } \\
\hline Net replacement rate & 41.5 & 52.5 & 43.5 & 39.2 & 34.3 & 31.3 \\
\hline \multicolumn{7}{|l|}{ (\% individual net earnings) } \\
\hline Net pension wealth & 5.6 & 7.2 & 5.9 & 5.3 & 4.5 & 4.0 \\
\hline (multiple of individual gross earnings) & 6.3 & 8.2 & 6.7 & 5.9 & 5.0 & 4.5 \\
\hline
\end{tabular}

Pension modelling results: Japan, pre-reform scenario

\begin{tabular}{|c|c|c|c|c|c|c|}
\hline \multirow{2}{*}{$\begin{array}{l}\text { Men } \\
\text { Women (where different) }\end{array}$} & \multirow{2}{*}{ Median earner } & \multicolumn{5}{|c|}{ Individual earnings, multiple of economy-wide average } \\
\hline & & 0.5 & 0.75 & 1 & 1.5 & 2 \\
\hline \multicolumn{7}{|l|}{ (\% average gross earnings) } \\
\hline Net relative pension level & 42.4 & 32.2 & 39.5 & 46.5 & 60.4 & 72.3 \\
\hline Gross replacement rate & 43.6 & 56.8 & 46.1 & 40.7 & 35.4 & 32.2 \\
\hline \multicolumn{7}{|l|}{ (\% individual gross earnings) } \\
\hline Net replacement rate & 49.4 & 62.9 & 51.9 & 46.5 & 41.7 & 38.2 \\
\hline \multicolumn{7}{|l|}{ (\% individual net earnings) } \\
\hline (multiple of individual gross earnings) & 8.1 & 10.6 & 8.6 & 7.6 & 6.6 & 6.0 \\
\hline Net pension wealth & 6.7 & 8.7 & 7.1 & 6.3 & 5.4 & 4.9 \\
\hline (multiple of individual gross earnings) & 7.6 & 9.8 & 8.0 & 7.1 & 6.1 & 5.5 \\
\hline
\end{tabular}




\section{Korea}

$\mathrm{T}$ he Korean public pension scheme was introduced relatively recently. It is an earningsrelated scheme with a progressive formula, since benefits are based on both individual earnings and the economy-wide average of earnings.

\section{Qualifying conditions}

The pension is currently available from age 60 provided the individual has contributed for ten years or more. A reduced, early pension can be drawn from age 55 .

The normal pension age is gradually being increased and will reach 65 from 2033. The modelling assumes the long-term pension age of 65 and that the early pension age will also be raised (from 55 to 60.)

\section{Benefit calculation}

\section{Earnings-related}

Benefits accrue at the rate of $1.5 \%$ of the earnings measure for the first 20 years of contributions. Thereafter, the benefit is increased by $5 \%$ for each additional year of contributions. The pension thus amounts to $60 \%$ of the earnings measure for 40 years of contributions. The earnings measure is the average of individual lifetime average earnings, valorised in line with wage growth, and average economy-wide earnings, measured over the previous three years and valorised in line with prices. There is a ceiling on pensionable earnings of KRW 3.6 million per month, equivalent to 1.6 times average earnings.

The maximum level of benefit is $100 \%$ of individual earnings. The benefit is indexed to prices after retirement. People over age 60 do not pay contributions and benefits are not accrued after this age.

\section{Early retirement}

When the normal pension age is increased from 60 to 65 , it is assumed that the early pension age will increase from 55 to 60 . At 60 , the early old-age pension will then be $75 \%$ of the normal old age pension. The benefit is increased by $5 \%$ every year, so a person who retires at age 64 will be entitled to $95 \%$ of the full old age pension.

\section{Late retirement}

People do not earn extra pension for retiring late, so it is assumed that people start claiming pension no later than age 65 .

In the future, individuals aged between 65 and 69 will be able to combine work and pension, known as the "active old-age pension". The pension payable during this period will be $50 \%$ of full old age pension with the benefit increasing by $10 \%$ for each year of additional work.

\section{Pre-reform scenario}

The basic structure of the current pension system has been maintained from its first introduction of 1988. At first, only employees were insured, but the self-employed in rural areas and urban areas were included in 1995 and 1999, respectively. In 1999, there was a parametric reform which resulted in a reduction of the replacement rate. For a person on average earnings and with 40 years of contributions, it was reduced from $70 \%$ to $60 \%$. There was also a lower pension age before reform (see above). 


\section{Pension modelling results: Korea}

Earnings-related

Gross relative pension level

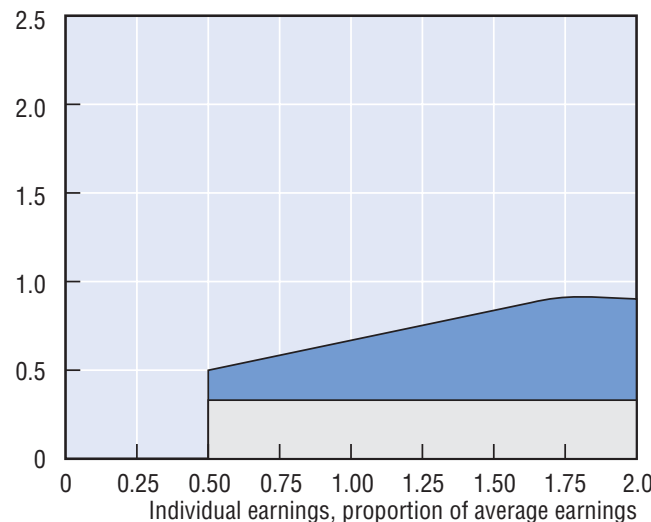

- Net

Net and gross relative pension levels

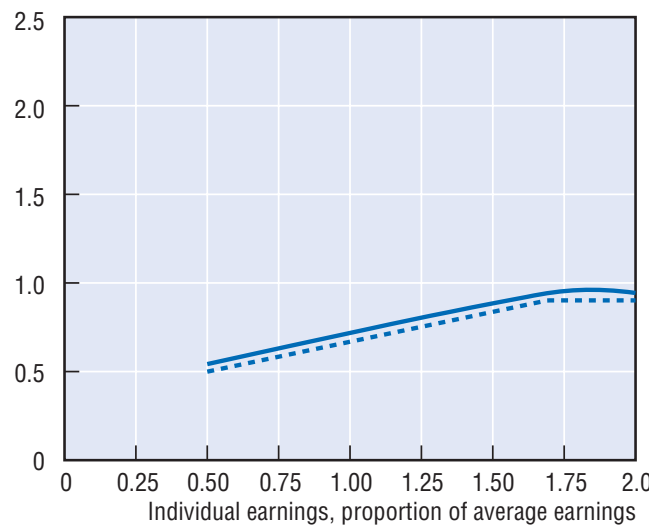

Basic

Gross replacement rate

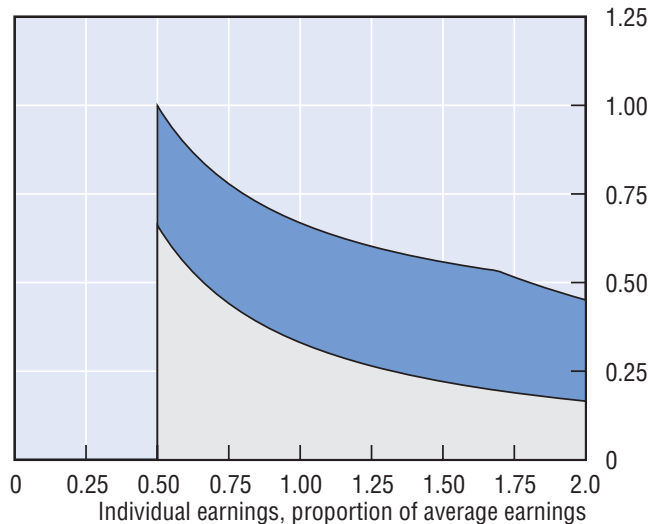

- . ... Gross

Net and gross replacement rates

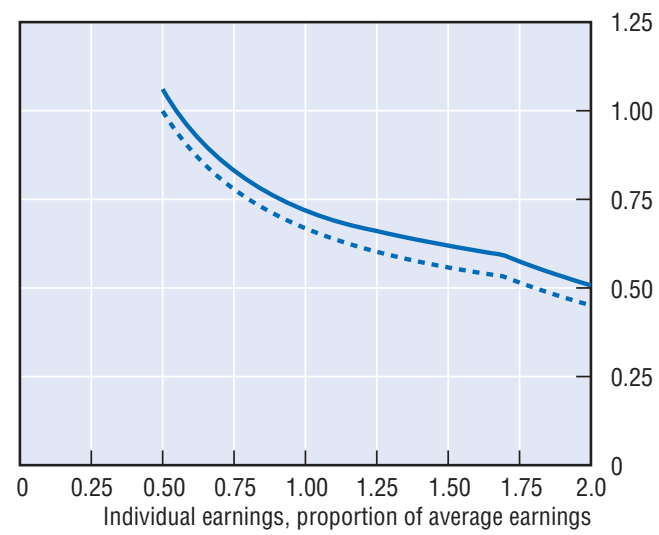

\begin{tabular}{|c|c|c|c|c|c|c|}
\hline \multirow{2}{*}{$\begin{array}{l}\text { Men } \\
\text { Women (where different) }\end{array}$} & \multirow{2}{*}{ Median earner } & \multicolumn{5}{|c|}{ Individual earnings, multiple of economy-wide average } \\
\hline & & 0.5 & 0.75 & 1 & 1.5 & 2 \\
\hline Gross relative pension level & 61.8 & 50.0 & 58.4 & 66.8 & 83.7 & 90.2 \\
\hline \multicolumn{7}{|l|}{ (\% average gross earnings) } \\
\hline Net relative pension level & 66.6 & 54.2 & 63.1 & 71.8 & 88.5 & 94.4 \\
\hline \multicolumn{7}{|l|}{ (\% net average earnings) } \\
\hline Gross replacement rate & 72.7 & 99.9 & 77.9 & 66.8 & 55.8 & 45.1 \\
\hline \multicolumn{7}{|l|}{ (\% individual gross earnings) } \\
\hline Net replacement rate & 77.8 & 106.1 & 83.1 & 71.8 & 61.9 & 50.7 \\
\hline \multicolumn{7}{|l|}{ (\% individual net earnings) } \\
\hline Gross pension wealth & 10.1 & 13.9 & 10.8 & 9.3 & 7.8 & 6.3 \\
\hline (multiple of individual gross earnings) & 12.1 & 16.6 & 12.9 & 11.1 & 9.3 & 7.5 \\
\hline Net pension wealth & 9.9 & 13.7 & 10.6 & 9.1 & 7.4 & 6.0 \\
\hline (multiple of individual gross earnings) & 11.8 & 16.3 & 12.7 & 10.8 & 8.9 & 7.1 \\
\hline
\end{tabular}


Pension modelling results: Korea, pre-reform scenario

\begin{tabular}{|c|c|c|c|c|c|c|}
\hline \multirow{2}{*}{$\begin{array}{l}\text { Men } \\
\text { Women (where different) }\end{array}$} & \multirow{2}{*}{ Median earner } & \multicolumn{5}{|c|}{ Individual earnings, multiple of economy-wide average } \\
\hline & & 0.5 & 0.75 & 1 & 1.5 & 2 \\
\hline Gross relative pension level & 64.1 & 50.0 & 60.6 & 69.3 & 86.8 & 93.5 \\
\hline \multicolumn{7}{|l|}{ (\% average gross earnings) } \\
\hline Net relative pension level & 68.9 & 54.3 & 65.3 & 74.3 & 91.3 & 97.4 \\
\hline \multicolumn{7}{|l|}{ (\% net average earnings) } \\
\hline Gross replacement rate & 75.4 & 100.0 & 80.7 & 69.3 & 57.9 & 46.8 \\
\hline \multicolumn{7}{|l|}{ (\% individual gross earnings) } \\
\hline Net replacement rate & 80.5 & 106.2 & 86.0 & 74.3 & 63.9 & 52.4 \\
\hline \multicolumn{7}{|l|}{ (\% individual net earnings) } \\
\hline Gross pension wealth & 12.4 & 16.5 & 13.3 & 11.4 & 9.5 & 7.7 \\
\hline (multiple of individual gross earnings) & 14.6 & 19.4 & 15.6 & 13.4 & 11.2 & 9.1 \\
\hline Net pension wealth & 12.1 & 16.2 & 13.0 & 11.1 & 9.1 & 7.3 \\
\hline (multiple of individual gross earnings) & 14.2 & 19.1 & 15.3 & 13.1 & 10.7 & 8.6 \\
\hline
\end{tabular}




\section{Luxembourg}

$\mathrm{T}$

he public pension scheme has two components: a flat-rate part depending on years of coverage and an earnings-related part. There is also a minimum pension.

\section{Qualifying conditions}

An early pension is payable from age 57 with 40 years' (compulsory or voluntary) contributions. With 40 years' coverage of compulsory, voluntary or credited contributions, the pension can be paid from age 60 . Since the modelling assumes a full career from age 20 , it is assumed in the base case that workers retire at age 60. Otherwise, the normal pension age is 65 (subject to at least ten years' contributions).

\section{Benefit calculation}

\section{Basic}

This was worth EUR 330 per month in 2004 (from August 2003), subject to 40 years' coverage. This is equivalent to around $10 \%$ of average earnings. For incomplete insurance, the benefit is reduced proportionally. (Formally, the basic pension is $23.5 \%$ of a reference amount, which was EUR 1403 in 2004.)

There is also an "end-of-year allowance", which adds EUR 45 per month to the pension for 40 years' contributions. This is proportionally reduced for insurance periods under 40 years, implying a little over EUR 1 per month for each year covered. The end-of-year allowance is indexed to nominal earnings (see below).

\section{Earnings-related}

The accrual rate for the earnings-related pension is $1.85 \%$. The earnings measure used in the formula is lifetime average pay revalued in line with nominal earnings.

The accrual rate is higher for older workers and those with longer contribution periods. For each year of work after age 55, the accrual rate is increased by 0.01 percentage points. Furthermore, each year of contributions beyond 38 also attracts an additional accrual of 0.01 percentage points. The maximum accrual rate is $2.05 \%$ per year. Under the standard assumption of a full career starting at age 20 and ending at age 60 , the accrual rate is $1.92 \%$.

The maximum pension in 2004 (from August 2003) was EUR 5847 per month (formally specified as $25 / 6$ of the reference amount). This is just under $180 \%$ of average earnings.

Benefits are automatically indexed to changes in the cost of living (if cumulative inflation is at least $2.5 \%$ ). In addition, adjustments to increases in real wages must be considered every two years. Recent practice has seen increases close to earnings and the modelling assumes that this practice continues.

\section{Minimum}

The minimum is EUR 1263 per month (defined as 90\% of the reference amount), conditional on 40 years' coverage, equivalent to about $39 \%$ of average earnings. This is proportionally reduced for shorter periods subject to a minimum of 20 years of service periods (compulsory, voluntary or credited contributions).

\section{Social assistance}

The social-assistance safety-net level is EUR 999 per month for a single person. 


\section{Early retirement}

It is possible to retire at 57 with 40 years' paid contributions and at 60 with 40 years' paid or credited contributions. Early retirees may work periodically provided earnings do not exceed one third of the minimum social income. There is no actuarial adjustment to benefits for early retirement.

In addition, there are a number of pre-retirement programmes. Relevant here are the pre-retirement solidarity and pre-retirement adaptation schemes. The first allows early retirement on the condition that the employer hires a job seeker assigned by the employment administration. The second allows early retirement for older workers losing their jobs due to restructuring or bankruptcy. Both schemes apply from age 57 up to age 60 . The pre-retirement benefit is $85 \%$ of prior earnings in the first year, $80 \%$ in the second year, and $75 \%$ in the third. The earnings measure is pay in the preceding three months.

\section{Late retirement}

The pension has to be claimed at the retirement age of 65 . After this age, it is possible to combine work and pension benefits without reductions in the pension benefit.

\section{Pension modelling results: Luxembourg}
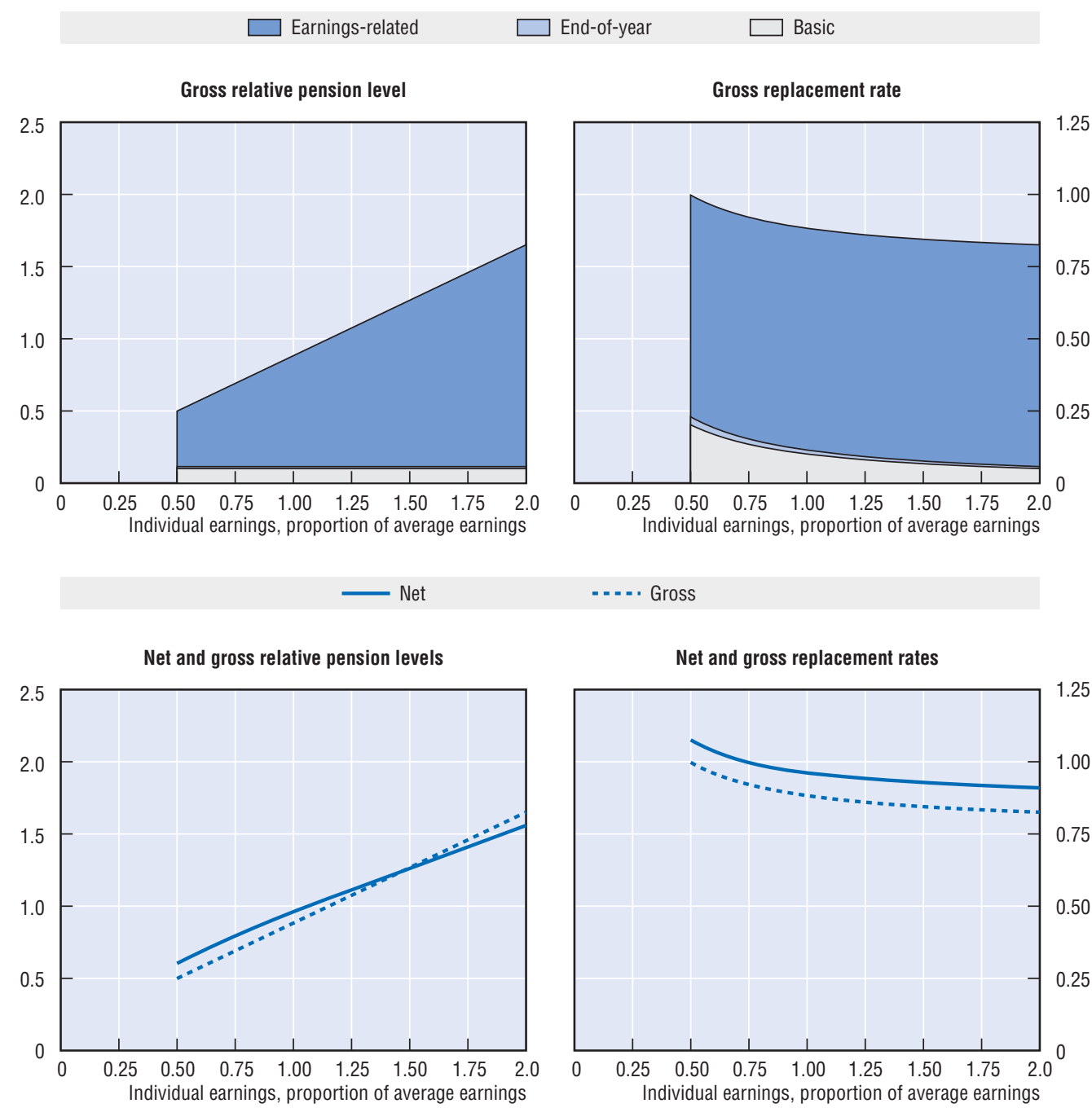


\begin{tabular}{|c|c|c|c|c|c|c|}
\hline \multirow{2}{*}{$\begin{array}{l}\text { Men } \\
\text { Women (where different) }\end{array}$} & \multirow{2}{*}{ Median earner } & \multicolumn{5}{|c|}{ Individual earnings, multiple of economy-wide average } \\
\hline & & 0.5 & 0.75 & 1 & 1.5 & 2 \\
\hline Gross relative pension level & 76.8 & 49.9 & 69.1 & 88.3 & 126.7 & 165.1 \\
\hline \multicolumn{7}{|l|}{ (\% average gross earnings) } \\
\hline Net relative pension level & 86.4 & 60.3 & 79.4 & 96.2 & 126.1 & 155.9 \\
\hline \multicolumn{7}{|l|}{ (\% net average earnings) } \\
\hline Gross replacement rate & 90.3 & 99.8 & 92.1 & 88.3 & 84.5 & 82.5 \\
\hline \multicolumn{7}{|l|}{ (\% individual gross earnings) } \\
\hline Net replacement rate & 98.0 & 107.6 & 99.8 & 96.2 & 92.9 & 91.0 \\
\hline \multicolumn{7}{|l|}{ (\% individual net earnings) } \\
\hline Gross pension wealth & 19.7 & 21.8 & 20.1 & 19.3 & 18.4 & 18.0 \\
\hline \multicolumn{7}{|l|}{ (multiple of individual gross earnings) } \\
\hline Net pension wealth & 16.5 & 19.6 & 17.2 & 15.6 & 13.7 & 12.7 \\
\hline (multiple of individual gross earnings) & & & & & & \\
\hline
\end{tabular}




\section{Mexico}

$\mathrm{N}$ ew labour-force entrants are obliged to join the new funded and privately managed, defined-contribution scheme. The government contributes 5.5\% of the 1997 real minimum wage to the individual account. There is also a minimum pension.

\section{Qualifying conditions}

Normal retirement age is 65 for men and women subject to 1250 weeks (around 25 years) of contribution.

\section{Benefit formula}

\section{Funded scheme}

Workers and employers contribute a total of $6.275 \%$ of earnings to an individual account to which is added a government contribution equivalent to $0.225 \%$ of earnings. An additional $5 \%$ contribution is made to an individual housing account (a scheme known as Infonavit) which reverts to the retirement account when it is not used. Finally, the government contributes $5.5 \%$ of the 1997 real minimum wage into all individual retirement accounts; this is considered to be the equivalent of a basic pension component here. The value of the flat contribution is equivalent to $1.4 \%$ of average earnings.

The calculations assume that the individual converts the accumulated account balance into a price-indexed annuity at normal pension age. Annuity rates in Mexico are sex-specific.

\section{Minimum pension}

The minimum pension is equivalent to the same 1997 real minimum wage value and was estimated to be approximately 26\% of the average covered wage in 2002 (MXN 20158 in 2004). The link to the real minimum wage means that the minimum pension is effectively price-indexed.

\section{Early retirement}

Early retirement is possible from age 60 for men and women. Conditions are that the worker is not employed and that at least 1250 weekly contributions have been made (or the contribution exemption period should be less than $25 \%$ of the entire insured period).

Workers who leave the labour market permanently may withdraw the entire balance from their defined contribution (Afore) account.

\section{Late retirement}

It is possible to defer the pension after age 65.

\section{Pre-reform scenario}

The Mexican pension system was reformed in 1999. All workers who were covered under the old system at the time of reform will be able to choose between the benefit resulting from the new system and the one that the old system would have paid. For new labour-market entrants, however, this option does not exist.

The old pension system is a defined-benefit system that provides a $35 \%$ replacement rate for the first ten years of contributions and an accrual of $1.25 \%$ of the earnings base for 
each year of contributions thereafter. Past earnings are valorised in line with average economy-wide earnings growth while pensions in payment are indexed to price inflation. The ceiling on pensionable earnings is MXN 288000.

There is a minimum pension of MXN 20158 or $26 \%$ of average earnings, the same as the minimum pension under the new system.

\section{Pension modelling results: Mexico}
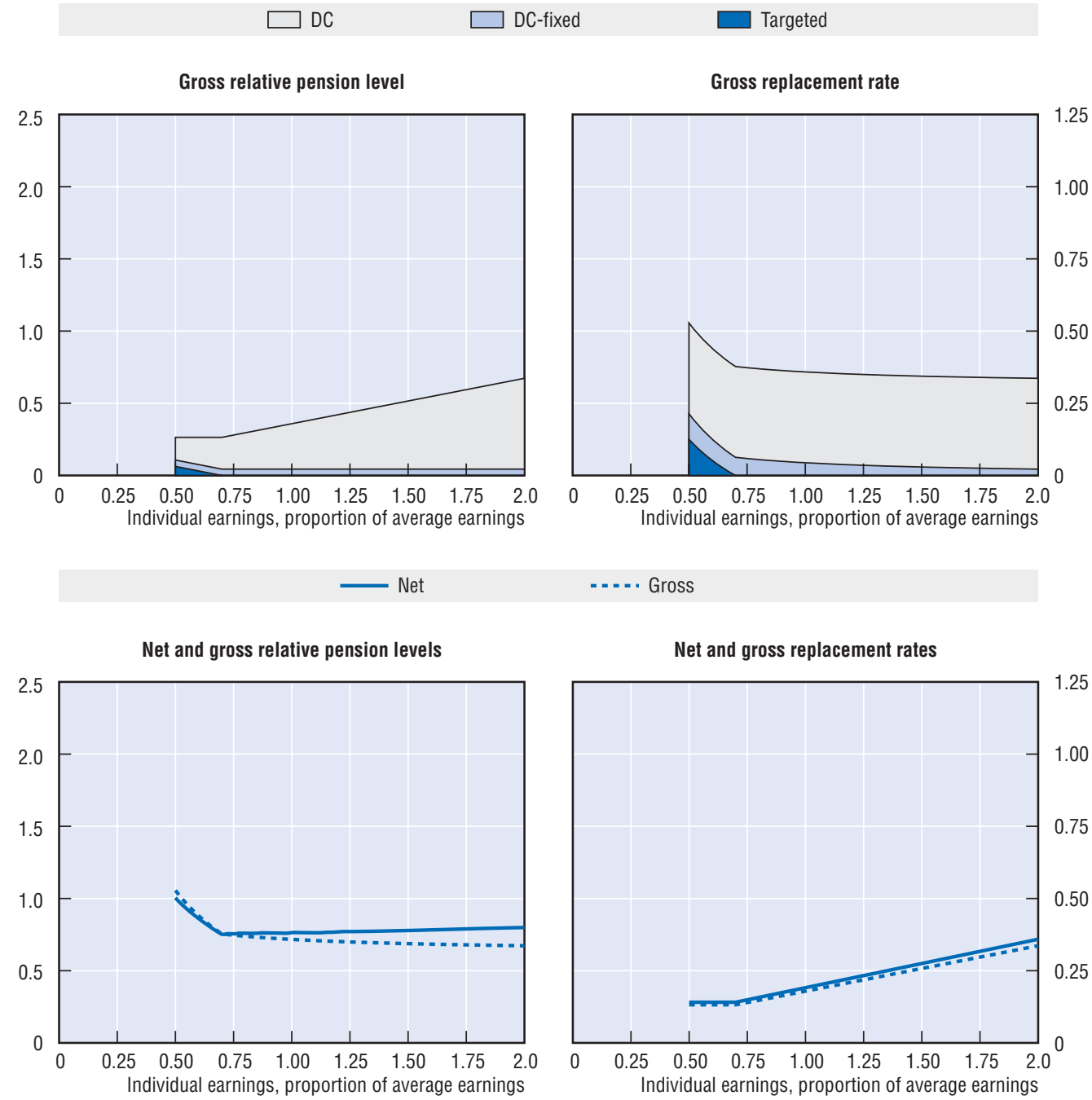


\begin{tabular}{|c|c|c|c|c|c|c|}
\hline \multirow{2}{*}{$\begin{array}{l}\text { Men } \\
\text { Women (where different) }\end{array}$} & \multirow{2}{*}{ Median earner } & \multicolumn{5}{|c|}{ Individual earnings, multiple of economy-wide average } \\
\hline & & 0.5 & 0.75 & 1 & 1.5 & 2 \\
\hline Gross relative pension level & 31.1 & 26.4 & 28.0 & 35.8 & 51.6 & 67.3 \\
\hline (\% average gross earnings) & 26.4 & 26.4 & 26.4 & 29.7 & 42.8 & 55.8 \\
\hline Net relative pension level & 33.2 & 28.2 & 29.9 & 38.3 & 55.1 & 71.8 \\
\hline (\% net average earnings) & 28.2 & 28.2 & 28.2 & 31.7 & 45.7 & 59.6 \\
\hline Gross replacement rate & 36.6 & 52.8 & 37.3 & 35.8 & 34.4 & 33.6 \\
\hline (\% individual gross earnings) & 31.1 & 52.8 & 35.2 & 29.7 & 28.5 & 27.9 \\
\hline Net replacement rate & 37.9 & 50.3 & 37.8 & 38.3 & 39.0 & 40.0 \\
\hline (\% individual net earnings) & 32.2 & 50.3 & 35.7 & 31.7 & 32.3 & 33.2 \\
\hline Gross pension wealth & 4.9 & 7.0 & 5.0 & 4.8 & 4.6 & 4.5 \\
\hline (multiple of individual gross earnings) & 5.0 & 8.5 & 5.6 & 4.8 & 4.6 & 4.5 \\
\hline Net pension wealth & 4.9 & 7.0 & 5.0 & 4.8 & 4.6 & 4.5 \\
\hline (multiple of individual gross earnings) & 5.0 & 8.5 & 5.6 & 4.8 & 4.6 & 4.5 \\
\hline
\end{tabular}

\section{Pension modelling results: Mexico, pre-reform scenario}

\begin{tabular}{|c|c|c|c|c|c|c|}
\hline \multirow{2}{*}{$\begin{array}{l}\text { Men } \\
\text { Women (where different) }\end{array}$} & \multirow{2}{*}{ Median earner } & \multicolumn{5}{|c|}{ Individual earnings, multiple of economy-wide average } \\
\hline & & 0.5 & 0.75 & 1 & 1.5 & 2 \\
\hline Gross relative pension level & 61.6 & 36.3 & 54.4 & 72.5 & 108.8 & 145.0 \\
\hline \multicolumn{7}{|l|}{ (\% average gross earnings) } \\
\hline Net relative pension level & 65.8 & 38.7 & 58.1 & 77.4 & 116.1 & 154.8 \\
\hline \multicolumn{7}{|l|}{ (\% net average earnings) } \\
\hline Gross replacement rate & 72.5 & 72.5 & 72.5 & 72.5 & 72.5 & 72.5 \\
\hline \multicolumn{7}{|l|}{ (\% individual gross earnings) } \\
\hline Net replacement rate & 75.1 & 69.0 & 73.5 & 77.4 & 82.2 & 86.2 \\
\hline \multicolumn{7}{|l|}{ (\% individual net earnings) } \\
\hline Gross pension wealth & 14.2 & 14.2 & 14.2 & 14.2 & 14.2 & 14.2 \\
\hline (multiple of individual gross earnings) & 17.4 & 17.4 & 17.4 & 17.4 & 17.4 & 17.4 \\
\hline Net pension wealth & 14.2 & 14.2 & 14.2 & 14.2 & 14.2 & 14.2 \\
\hline (multiple of individual gross earnings) & 17.4 & 17.4 & 17.4 & 17.4 & 17.4 & 17.4 \\
\hline
\end{tabular}




\section{Netherlands}

$\mathrm{T}$ he Dutch pension system has two main tiers, consisting of a flat-rate public scheme and earnings-related occupational plans. Although there is no statutory obligation for employers to offer a pension scheme to their employees, industrial-relations agreements mean that $91 \%$ of employees are covered. These schemes are therefore best thought of as quasi-mandatory.

\section{Qualifying conditions}

The basic old age pension is payable from age 65. Normal retirement age is typically also 65 in occupational plans. All residents are eligible for this benefit.

\section{Benefit calculation}

\section{Basic}

For a single person, the gross pension benefit in 2004 was EUR 921.28 in the first half of the year and EUR 920.12 in the second half. There was an additional holiday allowance of EUR 43.78 and EUR 43.69, respectively. This gives an annual total of EUR 11578 or 31\% of average earnings. For a couple, the total yearly benefit would be EUR 15906 . The benefit value is linked to the net minimum wage, which is uprated biannually.

The basic benefit accrues at $2 \%$ of the full value for each year a worker lives or works in the country. There is also a social-assistance scheme for older people. Its value is equal to the net basic pension.

\section{Occupational schemes}

The Netherlands also has a private pension system with broad coverage. The system consists of 819 pension funds; 101 of them are industry-wide schemes. Under certain conditions, Dutch companies may opt out of these plans if they offer their own scheme with equivalent benefits. Furthermore, there are around 700 single-employer plans. Another 40500 (in the year 2002) mainly smaller employers offer schemes operated by insurance companies.

Approximately $97 \%$ of the employees in these funds are covered by a defined-benefit scheme. The remaining employees are covered by a defined contribution scheme.

For about three quarters of participants in defined benefit schemes, the earnings measure is based on lifetime average earnings, and for $13 \%$ on the final salary. For the remainder it is either a combination of the two (9\%) or a fixed amount $(1 \%)$.

There is no statutory requirement for entry ages for occupational plans. In 2004, a little over half of the employees in a pension scheme were in schemes with no entry age, $8 \%$ in schemes with an age of $16-20,18 \%$ with an age of $21-24$ and nearly $19 \%$ with age 25 .

Most final-salary schemes give $1.75 \%$ of those earnings for each year of service, implying a replacement rate of $70 \%$ after a 40 -year career. In most average-salary schemes the accrual rate varies from $1.75 \%$ to $2 \%$ per year of service.

There are no legal requirements for valorisation of earlier years' pay and practice varies between schemes according to rules agreed upon by the social partners. For approximately $80 \%$ of the participants in average wage schemes, past earnings are 
valorised in line with growth of average earnings while for $6 \%$ the rate of inflation is used. The modelling assumes an average-salary scheme with valorisation to average earnings.

Although there is no legal uprating requirement, most pensions in payment are raised on an annual basis as well. Nearly half of the pensions in payment are indexed to wage growth in the respective industry, while $27 \%$ of the pensions are indexed to prices.

Pension rights are fully transferable when people change jobs. There is a legal requirement to index pension rights of people leaving a scheme before retirement in exactly the same way as pensions in payment are indexed. Vesting periods are very short.

There is no ceiling to pensionable earnings.

Occupational pensions are integrated with the public pension system. The current tax rules allow a maximum benefit of $100 \%$ of final pay at 65 from both public and private systems. Most schemes have a target total replacement rate of $70 \%$ of final pay, so private benefits are reduced by a franchise amount. In 2004, the average franchise amount was EUR 14 500, which is greater than the full basic pension.

\section{Early retirement}

The basic pension is not payable before age 65 .

There are separate early retirement programmes, called the Veruroegde Uittreding (VUT), which pay pre-pension benefits between ages 60 and 65 . The replacement rates differ between schemes; on average, they are about $80 \%$. The eligibility criteria differ hugely between companies and branches. In 2004, the government and the social partners agreed to end the tax-favoured status of the VUT schemes in order to increase labourmarket participation of older workers.

\section{Late retirement}

It is not possible to defer the basic old age pension scheme after 65. It is possible to combine the basic pension receipt with work.

The rules on pension deferral vary between occupational plans. It is possible to combine the occupational pension scheme with work. Indeed, some schemes allow a member to draw a pension and continue to work with the same employer. There is no legislation regarding this issue. 


\section{Pension modelling results: Netherlands}

Occupational

Gross relative pension level

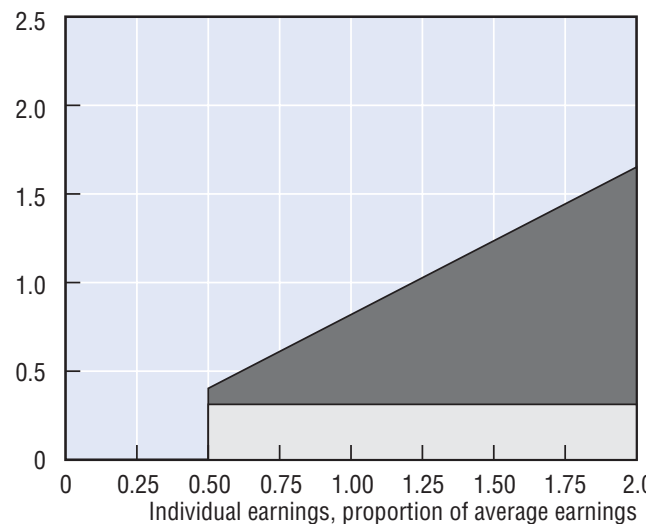

Net

Net and gross relative pension levels

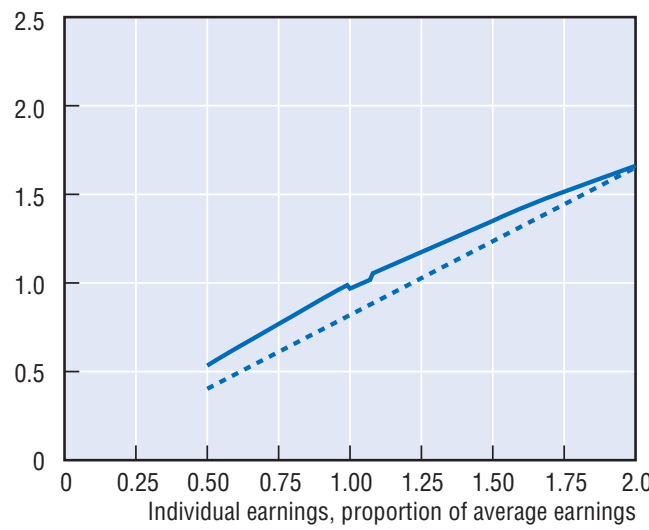

Basic

Gross replacement rate

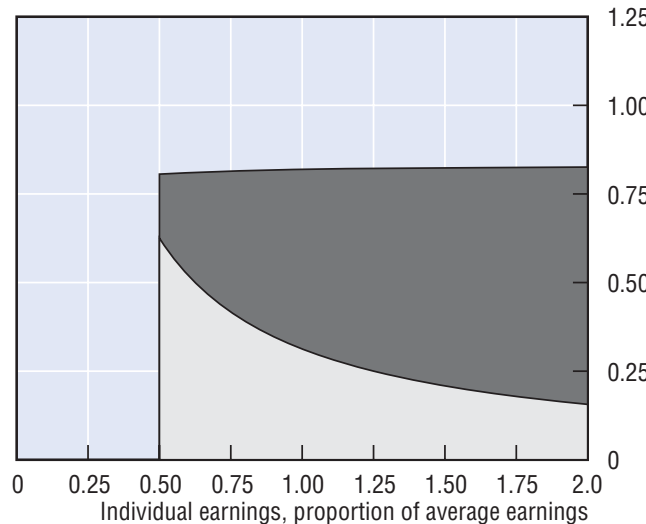

..... Gross

Net and gross replacement rates

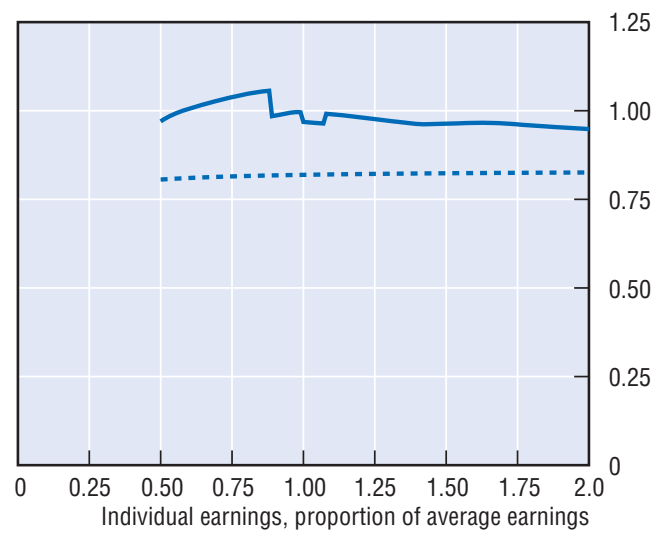

\begin{tabular}{|c|c|c|c|c|c|c|}
\hline \multirow{2}{*}{$\begin{array}{l}\text { Men } \\
\text { Women (where different) }\end{array}$} & \multirow{2}{*}{ Median earner } & \multicolumn{5}{|c|}{ Individual earnings, multiple of economy-wide average } \\
\hline & & 0.5 & 0.75 & 1 & 1.5 & 2 \\
\hline Gross relative pension level & 69.4 & 40.3 & 61.1 & 81.9 & 123.5 & 165.2 \\
\hline \multicolumn{7}{|l|}{ (\% average gross earnings) } \\
\hline Net relative pension level & 86.1 & 53.4 & 76.9 & 96.8 & 135.0 & 166.1 \\
\hline \multicolumn{7}{|l|}{ (\% net average earnings) } \\
\hline Gross replacement rate & 81.7 & 80.6 & 81.5 & 81.9 & 82.4 & 82.6 \\
\hline \multicolumn{7}{|l|}{ (\% individual gross earnings) } \\
\hline Net replacement rate & 105.3 & 97.0 & 103.8 & 96.8 & 96.3 & 94.8 \\
\hline \multicolumn{7}{|l|}{ (\% individual net earnings) } \\
\hline Gross pension wealth & 15.1 & 14.9 & 15.0 & 15.1 & 15.2 & 15.2 \\
\hline (multiple of individual gross earnings) & 17.6 & 17.4 & 17.6 & 17.7 & 17.8 & 17.8 \\
\hline Net pension wealth & 12.8 & 13.5 & 13.0 & 12.3 & 11.4 & 10.5 \\
\hline (multiple of individual gross earnings) & 15.0 & 15.8 & 15.2 & 14.3 & 13.3 & 12.3 \\
\hline
\end{tabular}




\section{New Zealand}

$\mathrm{T}_{\mathrm{r}}$ he public pension is flat rate and based on a residency test. There are occupational schemes but coverage has fallen since 1990 from $22.6 \%$ of the employed workforce to $14.1 \%$.

\section{Qualifying conditions}

Ten years' residency since the age of 20 (including five years after age 50) entitles people to the public pension at 65 years of age.

\section{Benefit calculation}

\section{Basic}

The pension for a single person living alone was NZD 301.33 gross per week from 1 April 2004. For 2003/04, the rate was NZD 296.49. This gives a total pension for the tax year 2004 of NZD 15 670, equivalent to around 40\% of average earnings.

The rate of public pension is indexed to prices, but is subject to a floor and ceiling linked to movement in wages. For a couple, the net-of-tax rate at each 1 April must be not less than $65 \%$ and not more than $72.5 \%$ of a net-of-tax surveyed weekly earnings measure. The net-of-tax rates for single people are set at 65\% (living alone) and 60\% (sharing accommodation) of the net-of-tax couple rate. If movements in prices remain consistently below movements in the net-of-tax surveyed weekly earnings, effectively the latter becomes the index.

\section{Early retirement}

It is not possible to claim the pension before the normal eligibility age of 65 .

\section{Late retirement}

Receipt of the public pension is not dependent on retirement. It is therefore possible to combine pension and employment.

While people are not obliged to claim the public pension on reaching the qualifying age, there is no advantage in deferring a claim.

\section{Pre-reform scenario}

The reform increased the pension age from 60 to 65 . 


\title{
Pension modelling results: New Zealand
}

\author{
Basic
}

Gross relative pension level

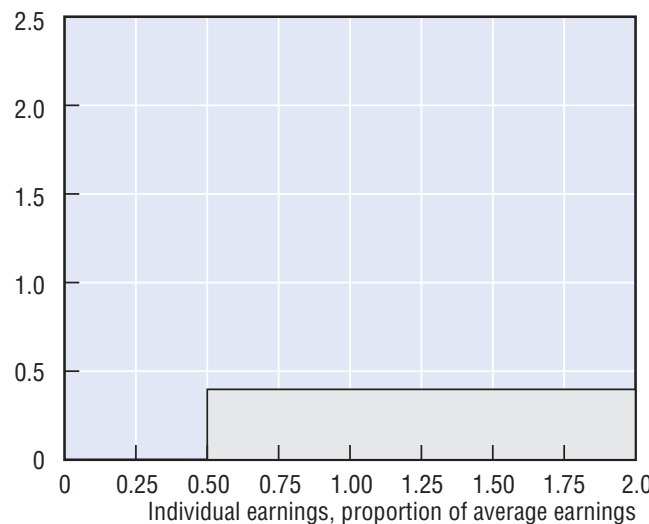

- Net

Net and gross relative pension levels

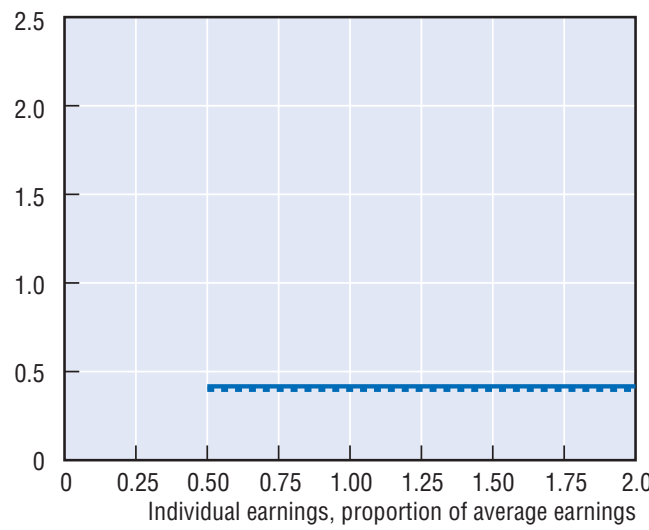

Gross replacement rate

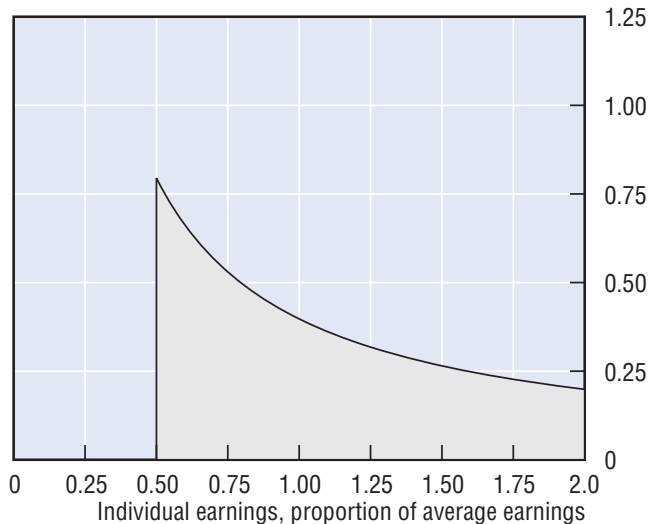

..... Gross

Net and gross replacement rates

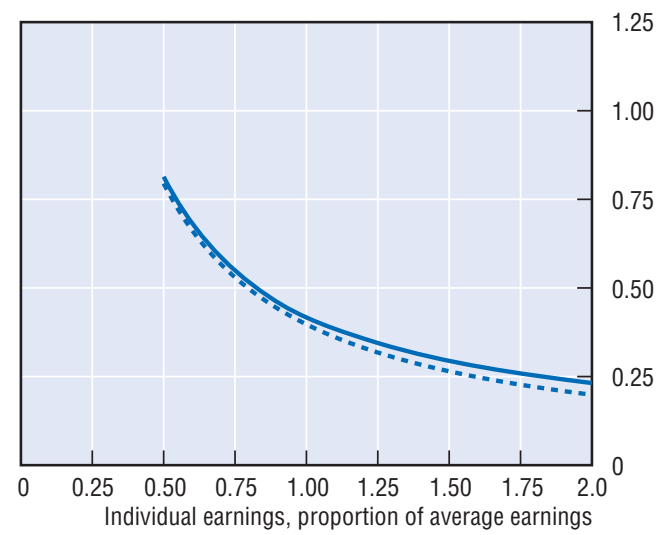

\begin{tabular}{|c|c|c|c|c|c|c|}
\hline \multirow{2}{*}{$\begin{array}{l}\text { Men } \\
\text { Women (where different) }\end{array}$} & \multirow{2}{*}{ Median earner } & \multicolumn{5}{|c|}{ Individual earnings, multiple of economy-wide average } \\
\hline & & 0.5 & 0.75 & 1 & 1.5 & 2 \\
\hline Gross relative pension level & 39.7 & 39.7 & 39.7 & 39.7 & 39.7 & 39.7 \\
\hline \multicolumn{7}{|l|}{ (\% average gross earnings) } \\
\hline Net relative pension level & 41.7 & 41.7 & 41.7 & 41.7 & 41.7 & 41.7 \\
\hline \multicolumn{7}{|l|}{ (\% net average earnings) } \\
\hline Gross replacement rate & 46.8 & 79.5 & 53.0 & 39.7 & 26.5 & 19.9 \\
\hline \multicolumn{7}{|l|}{ (\% individual gross earnings) } \\
\hline Net replacement rate & 48.6 & 81.4 & 54.9 & 41.7 & 29.4 & 23.2 \\
\hline \multicolumn{7}{|l|}{ (\% individual net earnings) } \\
\hline Gross pension wealth & 8.6 & 14.7 & 9.8 & 7.4 & 4.9 & 3.7 \\
\hline (multiple of individual gross earnings) & 10.2 & 17.3 & 11.5 & 8.6 & 5.8 & 4.3 \\
\hline Net pension wealth & 7.1 & 12.2 & 8.1 & 6.1 & 4.1 & 3.0 \\
\hline (multiple of individual gross earnings) & 8.4 & 14.3 & 9.5 & 7.1 & 4.8 & 3.6 \\
\hline
\end{tabular}


Pension modelling results: New Zealand, pre-reform scenario

\begin{tabular}{|c|c|c|c|c|c|c|}
\hline \multirow{2}{*}{$\begin{array}{l}\text { Men } \\
\text { Women (where different) }\end{array}$} & \multirow{2}{*}{ Median earner } & \multicolumn{5}{|c|}{ Individual earnings, multiple of economy-wide average } \\
\hline & & 0.5 & 0.75 & 1 & 1.5 & 2 \\
\hline Gross relative pension level & 39.7 & 39.7 & 39.7 & 39.7 & 39.7 & 39.7 \\
\hline \multicolumn{7}{|l|}{ (\% average gross earnings) } \\
\hline Net relative pension level & 41.7 & 41.7 & 41.7 & 41.7 & 41.7 & 41.7 \\
\hline \multicolumn{7}{|l|}{ (\% net average earnings) } \\
\hline Gross replacement rate & 46.8 & 79.5 & 53.0 & 39.7 & 26.5 & 19.9 \\
\hline \multicolumn{7}{|l|}{ (\% individual gross earnings) } \\
\hline Net replacement rate & 48.6 & 81.4 & 54.9 & 41.7 & 29.4 & 23.2 \\
\hline \multicolumn{7}{|l|}{ (\% individual net earnings) } \\
\hline Gross pension wealth & 10.5 & 17.9 & 11.9 & 8.9 & 6.0 & 4.5 \\
\hline (multiple of individual gross earnings) & 12.2 & 20.8 & 13.9 & 10.4 & 6.9 & 5.2 \\
\hline Net pension wealth & 8.7 & 14.8 & 9.8 & 7.4 & 4.9 & 3.7 \\
\hline (multiple of individual gross earnings) & 10.1 & 17.2 & 11.5 & 8.6 & 5.7 & 4.3 \\
\hline
\end{tabular}




\section{Norway}

$\mathrm{T}_{\mathrm{s}}$

he public pension system in Norway consists of a flat-rate basic pension, a special supplement and an earnings-related (supplementary) pension. Part of the minimum pension is means-tested against the earnings-related pension. Recently, a mandatory occupational pension was introduced.

\section{Qualifying conditions}

The current public system was introduced in 1967. As the required earnings period for a full pension is 40 years, the first cohort of old age pensioners that fulfil the insurance period is the one to retire in 2007. However, the requirements for the minimum pension and for people born before 1937 are relaxed to allow them higher pensions.

The normal pension age is 67 . Persons with a residence period in Norway of at least three years between the ages of 17 and 67 (inclusive) are entitled to the minimum pension, consisting of basic pension and special supplement. Full benefits are granted after a forty year long residence period. The requirement for a supplementary pension is at least three years of annual pension point earnings. A full pension is granted after 40 years. Both benefits are proportionally reduced for shorter earnings histories.

\section{Benefit calculation}

\section{Basic}

Many benefits under the National Insurance Scheme are determined in relation to the basic amount, G, that was NOK 58139 in 2004. The full basic pension for a single person equals the basic amount. This is equivalent to $18 \%$ of average earnings. Historically, indexation of the basic amount has been lower than average wage growth. However, the government has since 2002 linked the value of the basic amount to average earnings. The modelling assumes that this practice continues.

\section{Minimum}

The special supplement is $79.33 \%$ of the basic amount for 40 years of contribution and proportionally reduced for shorter contribution periods. This supplement is withdrawn against the earnings-related supplementary pension. The basic pension above and the special supplement form the minimum pension.

The overall minimum pension has been upgraded intermittently, as the special supplement has been increased in real terms. It has over time tended to track earnings growth. Again, since 2002 the minimum pension has been formally indexed to average earnings.

\section{Earnings-related}

Since the basic pension replaces the first slice of earnings, the earnings-related scheme only covers earnings above the value of the basic amount. The special supplement then replaces a further slice of earnings, up to 2.89 times the basic amount. The earningsrelated replacement rate falls for higher earnings. Annual earnings between 2.89 times the basic amount and six times the basic amount are replaced at a $42 \%$ rate (the rate was lowered from $45 \%$ in 1992 and is for each pensioner the average of these two weighted by 
the number of years with annual points prior to 1992). Between 6 and 12 times the basic amount, the replacement rate is one third of that level. Given that 40 years' contributions are needed for a full pension, these are equivalent to annual accrual rates (for those with all entitlements earned after 1992) of 1.05 and $0.35 \%$ respectively. The first threshold, where the accrual rate declines, is a little over average earnings (109\%). The ceiling on earnings eligible for benefits is therefore a little over double average earnings (219\%).

The calculation of the pension uses the best 20 years of point earnings. The valorisation of earlier years' accruals depends on the adjustment procedure for the value of the basic amount $(G)$. As discussed previously, the modelling assumes that the basic amount will in future be uprated in line with average earnings.

\section{Defined contribution}

From the beginning of 2006, employers must make a minimum contribution to a defined-contribution pension plan of $2 \%$ of the earnings of their employees. (If employers offer a defined-benefit scheme instead, then benefits must be at least the same level as the expected benefits under the mandatory $2 \%$ contribution.) Contributions are only required on earnings between the basic amount $(G)$ and 12 times the basic amount.

Benefits can currently only be taken at age 67. They must be withdrawn over a minimum period of ten years. For comparison with the results for other countries, it is assumed that the benefit is taken as a price-indexed annuity calculated using unisex mortality tables.

\section{Early retirement}

About two-thirds of employees work in businesses participating in early retirement programmes under the Contractual Early Retirement Scheme (AFP). This scheme, which was introduced in 1989, allows retirement from age 62. The pension level under this scheme is about the same as the ordinary old-age pension from 67 years of age, i.e. if the person had continued until that age in the job he/she was holding at the time he/she actually retired.

The calculation of AFP pensions differs between sectors. In the private sector, AFP pensions are calculated in the same manner as the permanent disability pension (granting pension points for the remaining years including 67). In addition, these pensioners receive a so-called AFP-supplement of NOK 11400 per year. This supplement is not taxed.

\section{Late retirement}

People can defer their pension after 67 and continue to work and people can combine working with receiving a pension.

Originally, the pension age was set at 70 but later reduced to 67 . The possibility of earning pension points based on labour income up to age 70 was kept, and for age groups 6770 the pension was (and is) income-tested against labour income. This income-testing consists of reducing the pension by $40 \%$ of labour income exceeding two basic amounts $(G)$ when the individual is combining work and pension.

There is no additional increment earned by deferring pension after 67, and the income testing from 67 to 70 is at $40 \%$ when combining work and pension. However, note that the latter only is effective for income exceeding two basic amounts $(G)$. 


\section{Pension modelling results: Norway}

$\square$ DC $\square$ Earnings-related $\square$ Basic

Gross relative pension level

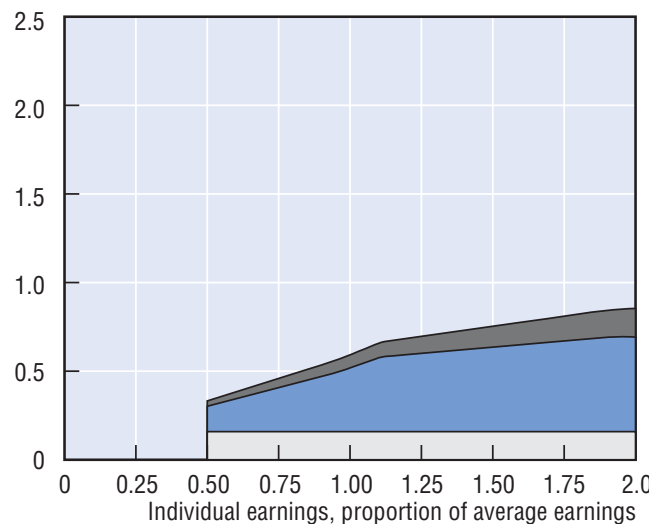

Net

Net and gross relative pension levels

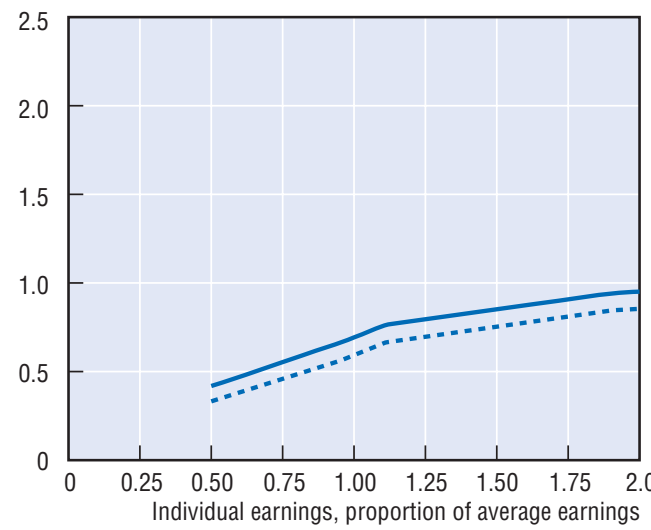

Gross replacement rate

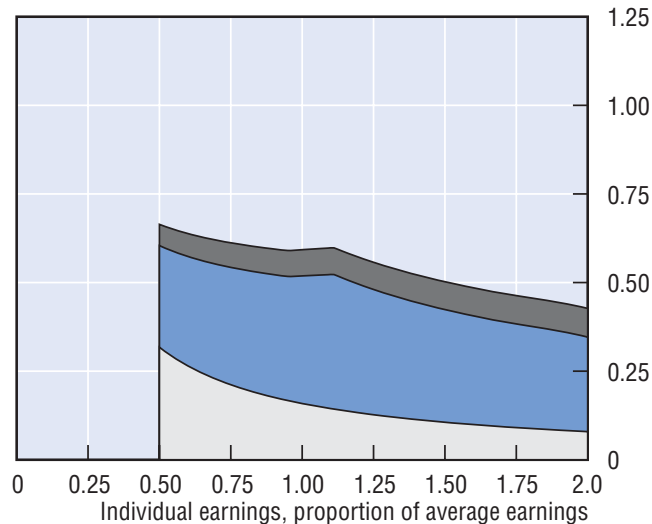

..... Gross

Net and gross replacement rates

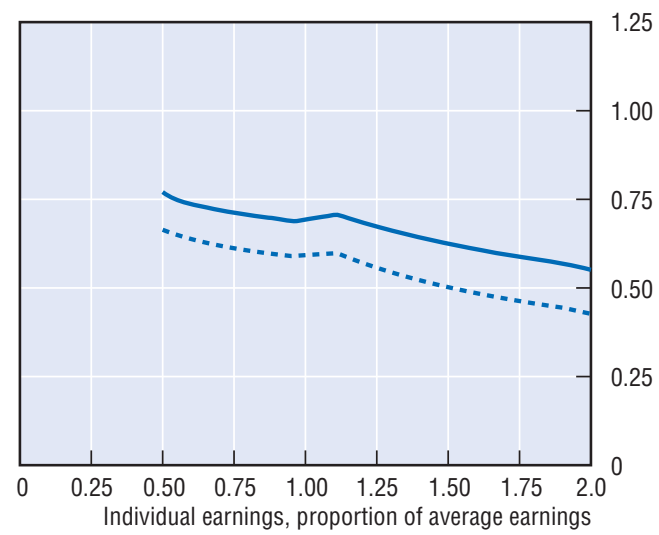

\begin{tabular}{|c|c|c|c|c|c|c|}
\hline \multirow{2}{*}{$\begin{array}{l}\text { Men } \\
\text { Women (where different) }\end{array}$} & \multirow{2}{*}{ Median earner } & \multicolumn{5}{|c|}{ Individual earnings, multiple of economy-wide average } \\
\hline & & 0.5 & 0.75 & 1 & 1.5 & 2 \\
\hline Gross relative pension level & 51.0 & 33.2 & 45.9 & 59.3 & 75.3 & 85.4 \\
\hline \multicolumn{7}{|l|}{ (\% average gross earnings) } \\
\hline Net relative pension level & 60.8 & 41.9 & 55.3 & 69.3 & 85.2 & 95.1 \\
\hline \multicolumn{7}{|l|}{ (\% net average earnings) } \\
\hline Gross replacement rate & 60.0 & 66.4 & 61.2 & 59.3 & 50.2 & 42.7 \\
\hline \multicolumn{7}{|l|}{ (\% individual gross earnings) } \\
\hline Net replacement rate & 70.0 & 77.1 & 71.2 & 69.3 & 62.5 & 55.1 \\
\hline \multicolumn{7}{|l|}{ (\% individual net earnings) } \\
\hline Gross pension wealth & 10.3 & 11.5 & 10.5 & 10.2 & 8.6 & 7.3 \\
\hline (multiple of individual gross earnings) & 12.1 & 13.4 & 12.3 & 11.9 & 10.0 & 8.5 \\
\hline Net pension wealth & 8.6 & 10.1 & 8.9 & 8.3 & 6.8 & 5.6 \\
\hline (multiple of individual gross earnings) & 10.1 & 11.8 & 10.4 & 9.7 & 7.9 & 6.6 \\
\hline
\end{tabular}




\section{Poland}

$\mathrm{T}$

he new pension system was introduced in 1999; it applies to people born in 1949 or after. The new public scheme is based on a system of notional accounts. People under 30 (born in 1969 and after) at the time of the reform must also participate in the funded scheme; people aged 30-50 (born between 1949 and 1968) could choose the funded option. However, the choice had to be made in 1999 and it was irrevocable.

\section{Qualifying conditions}

The minimum pension age in the new system will be 65 for men and 60 for women. For the minimum pension, 25 and 20 years' contributions are required from men and women, respectively.

\section{Benefit calculation}

\section{Earnings-related}

A contribution of $12.22 \%$ of earnings (or $19.52 \%$ for workers born between 1949 and 1968 who do not choose the defined-contribution option) will be credited to individuals' notional accounts. Initially, these contributions were uprated between the time they are made and the time of retirement by price inflation plus $75 \%$ of the growth of the real covered wage bill. From 2004 onwards, this notional interest rate has been defined as 100\% of the growth of the real covered wage bill and no less than price inflation. It is applied retrospectively to accounts from the year 2000.

At retirement, the accumulated notional capital is divided by the "g-value" to arrive at the pension benefit. The g-value is average life expectancy at retirement age: this process is equivalent to the process of annuitisation in funded pension systems. The g-value is calculated using life tables published by the Central Statistical Office. In the modelling, actuarial data from the UN/World Bank population database is used.

The ceiling to contributions and pensionable earnings was PLN 68700 or 2.3 times average earnings in 2004.

Between 1999 and 2004 pensions in payment were uprated in line with 80\% of prices and $20 \%$ of average earnings, projected for a given year. Note, however, that from 2005 the minimum indexation is to prices and adjustments are only made when compounded inflation reaches $5 \%$.

\section{Minimum pension}

There is a minimum pension under the pay-as-you-go scheme, which was PLN 562.86 per month in 2003-04, corresponding to $23 \%$ of average earnings. The minimum pension target was adjusted to $80 \%$ inflation plus $20 \%$ of wage growth but from 2005 , it is indexed to prices.

\section{Defined contribution}

Some 7.3 percentage points of the total contribution are diverted to the funded scheme for those compulsorily covered or choosing this option. The law on annuities has not been legislated yet. But it is assumed that at retirement, the accumulated capital will be converted to an annuity and at the minimum, annuities will be price-indexed (used in 
the model calculation). Annuity rates will most likely have to be based on unisex life-tables though this has not been decided yet.

\section{Early retirement}

There are no provisions for early retirement in the pension system. The old pension system (applicable to persons born before 1949) allowed various forms of early retirement for specific groups, such as miners, railway workers, teachers, people working in special conditions and women.

\section{Late retirement}

It is possible to defer both the notional and the funded, defined-contribution pension component without any age limits. People who defer claiming pension after normal pension age contribute and earn extra pension.

It is possible to combine work and pension receipt. For old-age pensioners below legal retirement age (in the old pension system), there are limits of income. If the work income is above $70 \%$ of average wage, the pension is reduced, if it is above $130 \%$ of average wage, the pension payment is suspended.

\section{Pre-reform scenario}

The pre-reform system was a defined-benefit scheme; there were no individual accounts. The old system had two components.

The first part paid a flat base amount, linked to average economy-wide earnings (net of social security contributions). The benefit is set at $24 \%$ of average earnings on a national definition. These were PLN 1862.62 in 2003-04 and PLN 1829.24 for 2004-05. The benefit in recent years is adjusted annually in March. The benefit was conditional on 25 years of contributions for men and 20 years for women.

The earnings-related component paid $1.3 \%$ of earnings for each year of contributions. The earnings measure was the best ten consecutive years in the final 20 or any period of 20 years in the whole career, relative to the average wage in the economy and multiplied by the base amount.

The minimum pension and ceiling are the same under the old system as under the new.

Pensions in payment were indexed from 1999 to prices plus at least $20 \%$ of the real wage growth projected for a given year and from 2005 they are indexed to prices (as with pensions under the new system). 


\section{Pension modelling results: Poland}

$D C$

Gross relative pension level

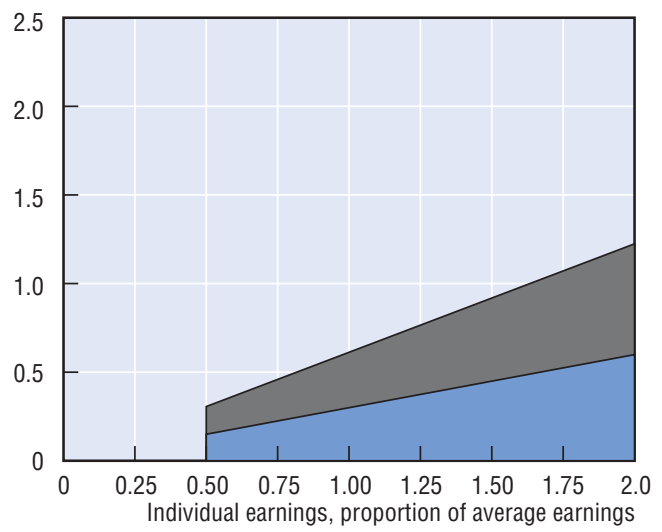

Net

Net and gross relative pension levels

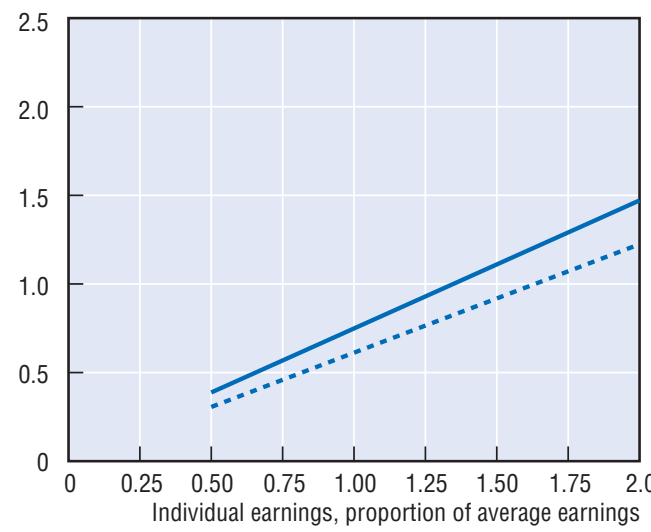

Earnings-related

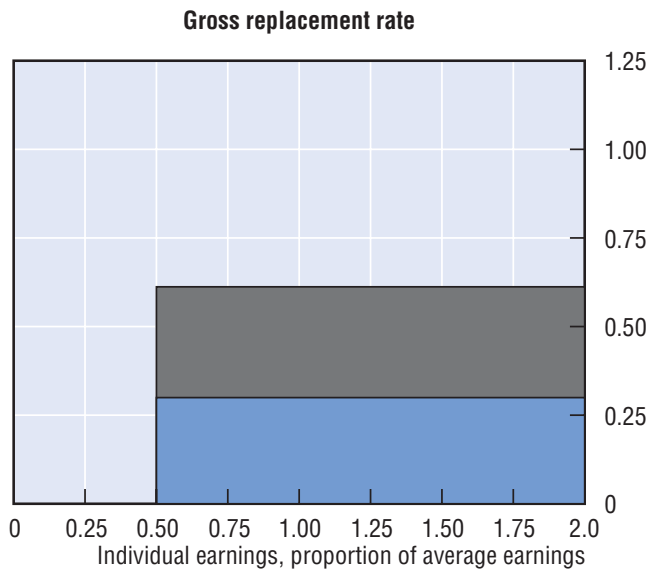

- . ... Gross

Net and gross replacement rates

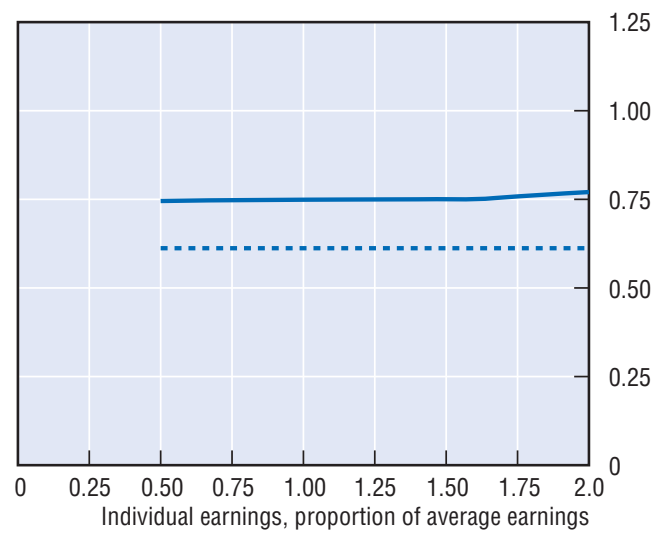

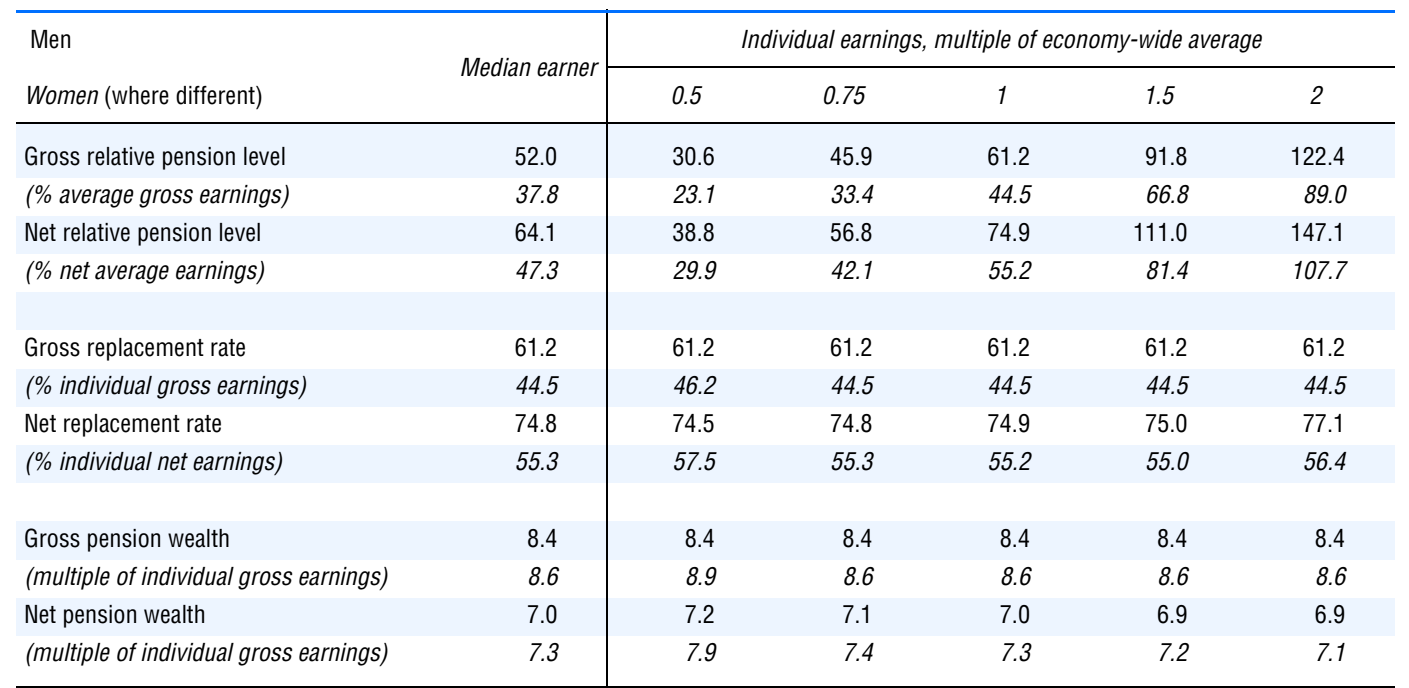


Pension modelling results: Poland, pre-reform scenario

\begin{tabular}{|c|c|c|c|c|c|c|}
\hline \multirow{2}{*}{$\begin{array}{l}\text { Men } \\
\text { Women (where different) }\end{array}$} & \multirow{2}{*}{ Median earner } & \multicolumn{5}{|c|}{ Individual earnings, multiple of economy-wide average } \\
\hline & & 0.5 & 0.75 & 1 & 1.5 & 2 \\
\hline Gross relative pension level & 55.6 & 40.1 & 51.1 & 62.2 & 84.2 & 106.3 \\
\hline (\% average gross earnings) & 51.4 & 37.7 & 47.5 & 57.3 & 76.9 & 96.5 \\
\hline Net relative pension level & 68.2 & 50.0 & 63.0 & 76.0 & 102.0 & 128.1 \\
\hline (\% net average earnings) & 63.3 & 47.1 & 58.7 & 70.2 & 93.4 & 116.5 \\
\hline Gross replacement rate & 65.4 & 80.3 & 68.2 & 62.2 & 56.1 & 53.1 \\
\hline (\% individual gross earnings) & 60.5 & 75.4 & 63.3 & 57.3 & 51.2 & 48.2 \\
\hline Net replacement rate & 79.7 & 96.1 & 82.9 & 76.0 & 69.0 & 67.1 \\
\hline (\% individual net earnings) & 74.0 & 90.6 & 77.2 & 70.2 & 63.1 & 61.0 \\
\hline Gross pension wealth & 9.0 & 11.0 & 9.3 & 8.5 & 7.7 & 7.3 \\
\hline (multiple of individual gross earnings) & 11.7 & 14.6 & 12.2 & 11.1 & 9.9 & 9.3 \\
\hline Net pension wealth & 7.5 & 9.3 & 7.9 & 7.1 & 6.4 & 6.0 \\
\hline (multiple of individual gross earnings) & 9.8 & 12.4 & 10.3 & 9.3 & 8.2 & 7.7 \\
\hline
\end{tabular}




\section{Portugal}

Portugal has an earnings-related public pension scheme with a minimum pension and a means-tested safety net.

\section{Qualifying conditions}

The standard pension age is 65 although early retirement is possible from age 55 . A minimum of 15 years of contributions are required for retirement at 65 . Early retirement is possible with 30 years of contributions.

The social pension is payable from age 65 .

\section{Benefit calculation}

\section{Earnings-related}

The pension accrues at $2 \%$ of the earnings base for each year of contributions for 20 or fewer years' contributions. For beneficiaries with 21 or more years of contributions, the accrual rate ranges between $2 \%$ and $2.3 \%$ depending on earnings. The schedule for the accrual rate depends on individual earnings relative to the value of the national minimum wage (EUR 365.60). Each slice of earnings accrues pension at a different rate.

\begin{tabular}{lccccc}
\hline Earnings/minimum wage & $\leq 1.1$ & $>1.1-2.0$ & $>2.0-4.0$ & $>4.0-8.0$ & $>8.0$ \\
Accrual rate $(\%)$ & 2.3 & 2.25 & 2.2 & 2.1 & 2.0 \\
\hline
\end{tabular}

Pension accrues for a maximum of 40 years.

The earnings measure is presently the best 10 of the final 15 years. However, this base is currently being extended, such that it will reach lifetime average earnings from 2017. The recent reform accelerated this change so that pensions of people retiring between 2006 and 2017 will be based pro rata on the best 10 of final 15 and lifetime-average earnings measures. People who joined the system after 2002 will be fully covered by the new rules. For people with more than 40 years' contributions, only the best 40 count in the benefit formula.

Valorisation of earnings for pension calculation from the beginning of 2002 is to a mix of earnings and prices. The weights are $75 \%$ price inflation and $25 \%$ earnings growth, subject to a maximum real increase of $0.5 \%$.

The recently agreed pension reform introduces an adjustment of future pensions to increases in life expectancy at age 65 , known as the sustainability factor. Based on the UN/ World Bank database on mortality rates, life expectancy in Portugal at age 65 in the year 2006 is 16.2 years. This is projected to increase to 20.3 years life expectancy in 45 years' time. Thus, benefits are expected to be $81 \%$ of their value under current rules as a result of the link to life expectancy for an individual spending a whole career with this adjustment.

Pensions in payment are now progressively indexed, with larger increases on smaller pensions. In addition, indexation will be more generous if GDP growth is higher. The following matrix will apply from 2008. 


\begin{tabular}{c|ccc}
\hline \multicolumn{2}{c}{ Pension } & \multicolumn{3}{c}{ GDP growth } \\
\hline Multiple of IAS & $<2 \%$ & $2-3 \%$ & $\geq 3 \%$ \\
\hline$<1.5$ & $\mathrm{CPI}$ & $\mathrm{CPI}+20 \% \mathrm{GDP}$ growth & $\mathrm{CPI}+20 \%$ GDP growth \\
$1.5-6$ & $\mathrm{CPI}-0.5$ p.p. & $\mathrm{CPI}$ & $\mathrm{CPI}+12.5 \%$ GDP growth \\
$6-12$ & $\mathrm{CPI}-0.75$ p.p. & $\mathrm{CPI}-0.25$ p.p. & $\mathrm{CPI}$ \\
$\geq 12$ & zero & zero & zero \\
\hline
\end{tabular}

Note: $\mathrm{CPI}=$ consumer price inflation; GDP = gross domestic product; $p . p .=$ percentage point. The IAS is a measure of a minimum subsistence income. For 2007, the IAS will be based on the minimum wage for 2006 (EUR 385.90) uprated by inflation for 2006 (3.1\%). It is not yet determined how the IAS will evolve over time, but the modelling assumes that it will track average earnings in the long term.

* Subject to a minimum limit of 0.5 percentage points above inflation.

\section{Minimum}

There is a monthly minimum pension of EUR 208 from January to May 2004, EUR 211.50 from June to November and EUR 216.79 from December 2004 (for workers with up to 15 years of contributions). For workers with 15 to 40 years, the amount of the minimum pension varies between $65 \%$ and $100 \%$ of the minimum wage net of employee's social contributions. For 2004, the lower limit was EUR 217.65 (January-May), EUR 222 (JuneNovember) and EUR 233.10 (December-) and the upper limit was EUR 325.31, EUR 325.38 and EUR 333.51 for the same three periods, as described in the table below. In annual terms, the minimum pension varied between EUR 3096 and EUR 4564 of average earnings in calendar 2004.

There are 14 monthly payments.

\begin{tabular}{lccc}
\hline & & Minimum pension (euros) & \\
\cline { 2 - 4 } Years of contributions & January-May & June-November & December \\
\hline 15 and 16 & 217.65 & 222.00 & 233.10 \\
17 and 18 & 222.48 & 226.93 & 236.01 \\
19 and 20 & 227.31 & 231.86 & 238.82 \\
21 and 22 & 238.43 & 243.20 & 255.36 \\
23 and 24 & 243.25 & 248.12 & 259.29 \\
25 and 26 & 248.08 & 253.04 & 263.16 \\
27 and 28 & 252.90 & 257.96 & 265.70 \\
29 and 30 & 257.72 & 260.30 & 266.81 \\
31 & 279.33 & 284.92 & 310.56 \\
32 & 284.16 & 289.84 & 313.03 \\
33 & 288.99 & 294.77 & 315.64 \\
34 & 293.81 & 299.69 & 317.67 \\
35 & 298.63 & 304.60 & 319.83 \\
36 & 303.46 & 309.53 & 325.01 \\
37 & 308.28 & 314.45 & 327.03 \\
38 & 313.12 & 319.38 & 328.96 \\
39 & 317.94 & 324.30 & 332.41 \\
40 and over & 325.31 & 325.38 & 333.51 \\
\hline
\end{tabular}

\section{Targeted}

For people who do not qualify for the earnings-related scheme, the monthly social pension was EUR 151.84 (January-May 2004), EUR 154.88 (June-November) and EUR 164.17 (December-). 
This is only paid if total income for a single person does not exceed $30 \%$ of the minimum wage or $50 \%$ of the minimum wage in case of couples. Again, there are 14 monthly payments.

Minimum pension amounts and other social benefits will be linked to the IAS according to the following table:

\begin{tabular}{lc}
\hline Benefits & Amount (\% IAS) \\
\hline Minimum pension (earnings related) & \\
15 years of contributions & 57.8 \\
15 to 20 years of contributions & 64.5 \\
21 to 30 years of contributions & 71.2 \\
More than 30 years of contributions & 89.0 \\
Social pension & 44.5 \\
\hline
\end{tabular}

\section{Early retirement}

Early retirement is possible at age 55 with 30 years' contributions. There is a decrement of $0.5 \%$ for each month of early retirement ( $6 \%$ per year). If the individual has more than 30 years' contributions on reaching age 55 , then the number of years over which the pension is adjusted is cut by one year for each complete three years of contributions beyond 30 years.

\section{Late retirement}

It is possible to defer the pension after age 65. The recent reform allows for a pension increment of $1 \%$ per month for people with a full ( 40 -year) career (12\% per year). For people with incomplete contribution histories, the increase varies between $0.33 \%$ per month ( $<25$ years career) and $0.65 \%$ (35-39 years).

Individuals who qualify for retirement before age 65 will, as a result of the recent reform, receive an increment of $0.65 \%$ per month of deferral ( $7.8 \%$ per year).

All of these increases are granted subject to a maximum replacement rate of $92 \%$.

\section{Pre-reform scenario}

The pre-reform scenario models benefits using the measure of the best 10 of the final 15 years' earnings. It also excludes the sustainability adjustment. 


\section{Pension modelling results: Portugal}

Earnings-related

Gross relative pension level

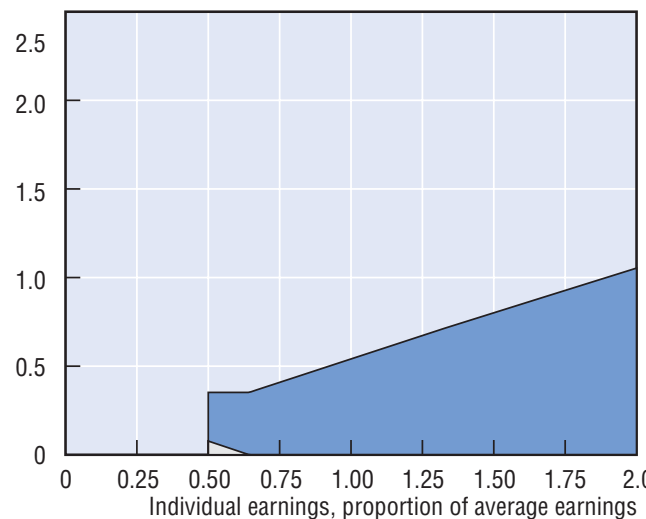

- Net

Net and gross relative pension levels

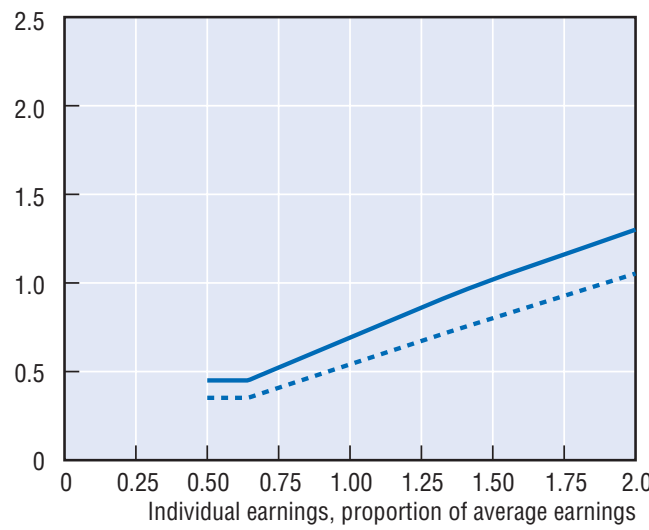

Minimum

Gross replacement rate

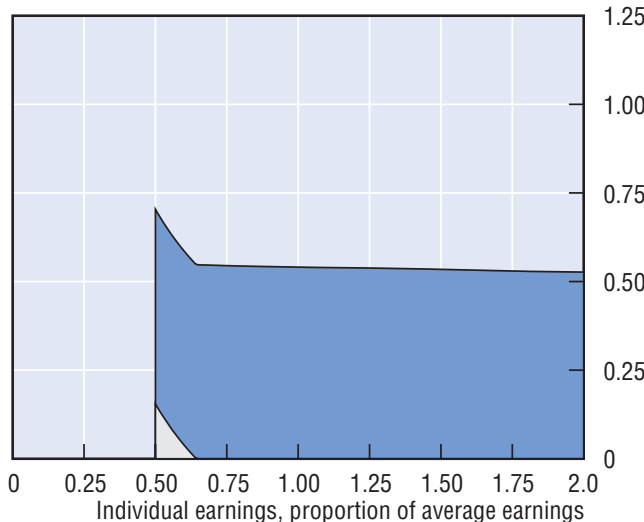

..... Gross

Net and gross replacement rates

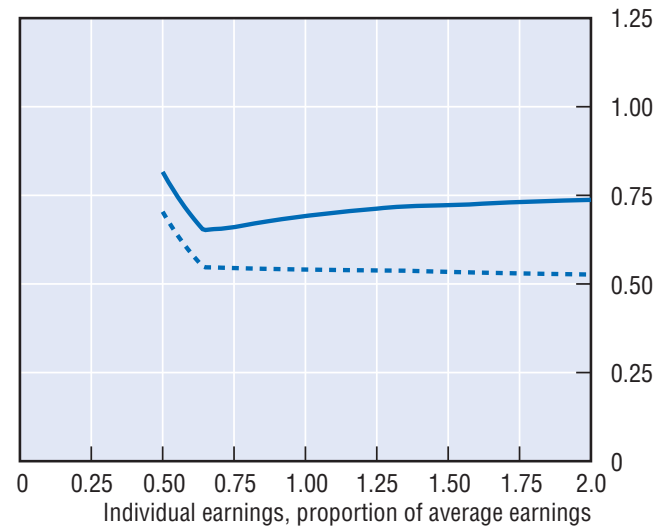

\begin{tabular}{|c|c|c|c|c|c|c|}
\hline \multirow{2}{*}{$\begin{array}{l}\text { Men } \\
\text { Women (where different) }\end{array}$} & \multirow{2}{*}{ Median earner } & \multicolumn{5}{|c|}{ Individual earnings, multiple of economy-wide average } \\
\hline & & 0.5 & 0.75 & 1 & 1.5 & 2 \\
\hline Gross relative pension level & 46.1 & 35.2 & 40.9 & 54.1 & 80.1 & 105.3 \\
\hline \multicolumn{7}{|l|}{ (\% average gross earnings) } \\
\hline Net relative pension level & 59.0 & 45.0 & 52.3 & 69.2 & 102.0 & 130.1 \\
\hline \multicolumn{7}{|l|}{ (\% net average earnings) } \\
\hline Gross replacement rate & 54.3 & 70.4 & 54.5 & 54.1 & 53.4 & 52.7 \\
\hline \multicolumn{7}{|l|}{ (\% individual gross earnings) } \\
\hline Net replacement rate & 67.4 & 81.6 & 66.0 & 69.2 & 72.2 & 73.7 \\
\hline \multicolumn{7}{|l|}{ (\% individual net earnings) } \\
\hline Gross pension wealth & 8.2 & 10.5 & 8.2 & 7.9 & 7.8 & 7.7 \\
\hline (multiple of individual gross earnings) & 9.6 & 12.3 & 9.6 & 9.2 & 9.1 & 9.0 \\
\hline Net pension wealth & 8.2 & 10.5 & 8.2 & 7.9 & 7.8 & 7.4 \\
\hline (multiple of individual gross earnings) & 9.6 & 12.3 & 9.6 & 9.2 & 9.0 & 8.7 \\
\hline
\end{tabular}


Pension modelling results: Portugal, pre-reform scenario

\begin{tabular}{|c|c|c|c|c|c|c|}
\hline \multirow{2}{*}{$\begin{array}{l}\text { Men } \\
\text { Women (where different) }\end{array}$} & \multirow{2}{*}{ Median earner } & \multicolumn{5}{|c|}{ Individual earnings, multiple of economy-wide average } \\
\hline & & 0.5 & 0.75 & 1 & 1.5 & 2 \\
\hline Gross relative pension level & 76.9 & 45.7 & 68.1 & 90.1 & 133.5 & 175.5 \\
\hline \multicolumn{7}{|l|}{ (\% average gross earnings) } \\
\hline Net relative pension level & 98.3 & 58.5 & 87.1 & 113.2 & 158.4 & 199.2 \\
\hline \multicolumn{7}{|l|}{ (\% net average earnings) } \\
\hline Gross replacement rate & 90.5 & 91.5 & 90.8 & 90.1 & 89.0 & 87.8 \\
\hline \multicolumn{7}{|l|}{ (\% individual gross earnings) } \\
\hline Net replacement rate & 112.4 & 106.1 & 110.0 & 113.2 & 112.1 & 112.9 \\
\hline \multicolumn{7}{|l|}{ (\% individual net earnings) } \\
\hline Gross pension wealth & 13.2 & 13.3 & 13.2 & 13.1 & 13.0 & 12.8 \\
\hline (multiple of individual gross earnings) & 15.4 & 15.6 & 15.4 & 15.3 & 15.1 & 14.9 \\
\hline Net pension wealth & 13.2 & 13.3 & 13.2 & 12.9 & 12.0 & 11.4 \\
\hline (multiple of individual gross earnings) & 15.4 & 15.6 & 15.4 & 15.1 & 14.0 & 13.2 \\
\hline
\end{tabular}




\section{Slovak Republic}

$\mathrm{T}_{\mathrm{h}}$ he earnings-related, public scheme is similar to a points system, with benefits that depend on individual earnings relative to the average. There is no minimum pension, but low-income workers are protected by a minimum amount of earnings on which pension is calculated. All pensioners are eligible for social assistance benefits. Defined-contribution plans were introduced at the beginning of 2005.

\section{Qualifying conditions}

Ten years of pension insurance are needed to be eligible for a benefit. Pension ages are being increased gradually, to be equalised between the sexes at age 62 . For men, pension age will reach 62 from 2006. For women, the increase in pension age will be spread over the period 2004-14.

\section{Benefit calculation}

\section{Earnings-related}

Contributors to the pension scheme earn annual pension points. These are calculated as the ratio of individual earnings to economy-wide average earnings. The pension entitlement is the sum of pension points over the career multiplied by the pension-point value. This was SKK 183.58 for 2004. The pension-point value is indexed to average earnings. National average earnings in 2004 were SKK 15825 per month. Dividing the point value by the earnings figure gives the equivalent to the accrual rate in a defined-benefit scheme, which is just under $1.2 \%$.

There is a ceiling to earnings for contribution and benefit purposes, which is set at three times average earnings. The earnings data are lagged, so the ceiling for the first half of 2004 was three times average earnings in 2002 (SKK 13511 per month). In the second half, the ceiling was based on 2003 data for average earnings (SKK 14365 per month). (At the baseline assumptions for earnings growth and price inflation, the lagging means that the ceiling is slightly less than three times contemporaneous average earnings.)

Pensions in payment are indexed to the arithmetic average of earnings growth and price inflation.

For workers joining defined-contribution plans, the benefits under the public, earnings-related scheme are half of those of workers who remain only in the public plan.

\section{Minimum}

There is no minimum pension. However, there is a minimum assessment base for pension purposes that is equal to the minimum wage. The minimum wage was SKK 6500 from the beginning of October 2004 and SKK 6080 earlier in the year. The minimum wage is worth just under $40 \%$ of average earnings.

\section{Defined contribution}

The contribution rate for the defined-contribution scheme is $9 \%$ of earnings. Participation is mandatory for workers entering the labour market from January 2005; all others may choose by June 2006 to remain solely under the public scheme or join the mixed system. The defined-contribution pension can be taken as an annuity or as a combination 
of scheduled withdrawal and annuity. The modelling assumes withdrawal in the form of a price-indexed annuity calculated using unisex annuity rates.

\section{Early retirement}

Early retirement is possible. Benefits are reduced by $0.5 \%$ per month that the pension is claimed early (equivalent to $6 \%$ per year). Early retirement requires that the resulting pension is equal to at least 1.2 times the adult subsistence income level, which was SKK 5052 in the first half of 2004 and SKK 5497 in the second half. The subsistence minimum for the calendar year 2004 was worth $32 \%$ of average earnings, meaning that the minimum pension required for early retirement is $38 \%$ of average earnings.

There is currently no age limit on early retirement: it is theoretically possible at any age provided the ten-year contribution condition and the requirement for the level of the benefit are both met.

\section{Late retirement}

It is possible to defer claiming the pension after the normal pension age. The benefit is increased by $0.5 \%$ for each month of deferral ( $6 \%$ per year). For people who claim the pension and continue to work, the pension will be recalculated when the individual eventually retires adding one half of the points earned during that period.

\section{Pre-reform scenario}

The new pension scheme is applicable to the pension claims arising from 1 January 2004. Workers who had reached the pension eligibility age under the old system but not yet claimed their pension were entitled to the higher of the pension calculated under the old or new rules.

Under the old system, eligibility for a (full) pension required 25 years of contributions or credited periods. Normal pension age was 60 for men and 57 for women. Pension ages were lower for men in hazardous or arduous work and for women who had raised children.

The pension was $50 \%$ of earnings plus $1 \%$ for each year of contributions over 25 years. The earnings measure was the best five years in the final ten. There was a maximum pension of SKK 8282 per month in the first half of 2002 and SKK 8697 in the second half. This gave an annual total for 2002 of SKK 101 874, equivalent to 63\% of average earnings in that year. Based on Slovak Government estimates of 10.2\% nominal wage growth in 2004 and actual wage growth of 6.3\% in 2003, the annual maximum pension for 2004 would have been SKK 119338 (had the system not been reformed). This is worth around two-thirds of average earnings.

Pensions in payment under the old system were increased in line with the growth of average earnings (provided the growth was at least 5\%).

There was a minimum pension under the old system and this was SKK 550 per month plus an adjustment to reflecting changes in living standards. For 2002, the minimum pension was therefore SKK 1240 per month. Given the growth in earnings since 2002 (see above), the modelling assumes a 2004 value for the minimum pension of SKK 1453 per month, equivalent to around 10\% of average earnings. Again, 25 years' contributions were required to receive the minimum pension.

There was no early retirement under the old pension system. For late retirement, pensions were increased by $6 \%$ for each year the claim was deferred. 


\section{Pension modelling results: Slovak Republic}

DC

Gross relative pension level

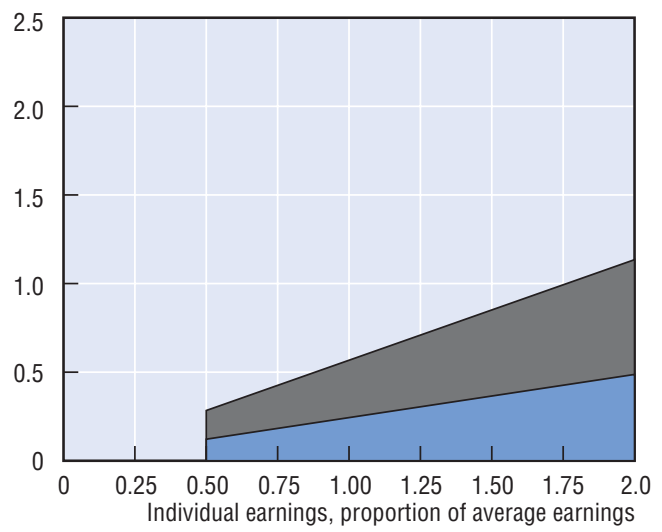

Net

Net and gross relative pension levels

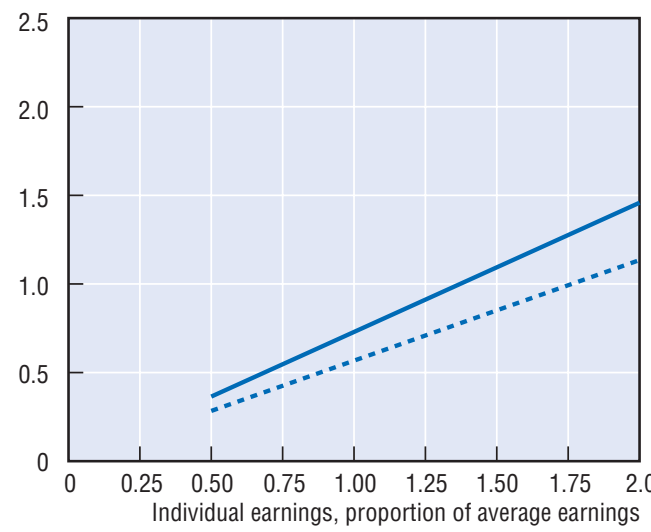

Earnings-related

Gross replacement rate

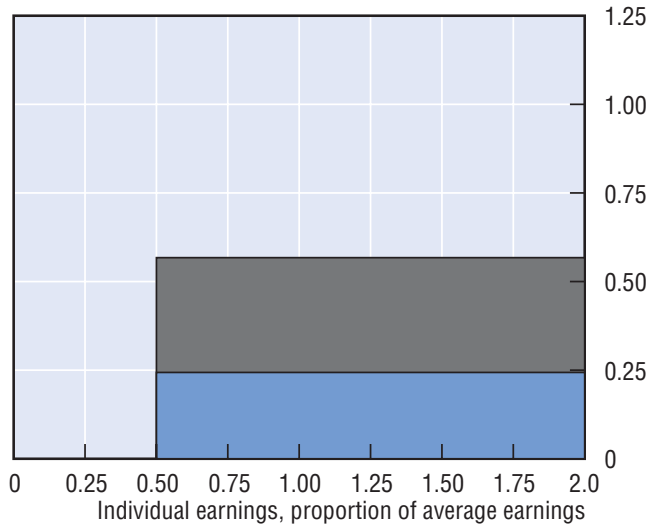

..... Gross

Net and gross replacement rates

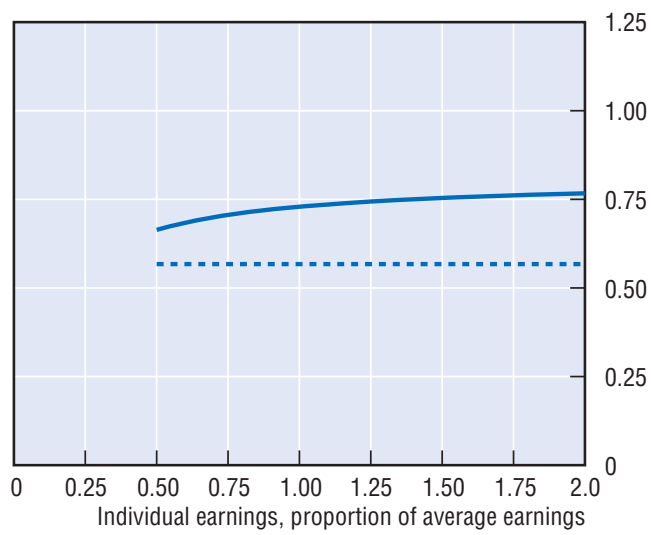

\begin{tabular}{|c|c|c|c|c|c|c|}
\hline \multirow{2}{*}{$\begin{array}{l}\text { Men } \\
\text { Women (where different) }\end{array}$} & \multirow{2}{*}{ Median earner } & \multicolumn{5}{|c|}{ Individual earnings, multiple of economy-wide average } \\
\hline & & 0.5 & 0.75 & 1 & 1.5 & 2 \\
\hline Gross relative pension level & 48.2 & 28.4 & 42.6 & 56.7 & 85.1 & 113.5 \\
\hline \multicolumn{7}{|l|}{ (\% average gross earnings) } \\
\hline Net relative pension level & 62.0 & 36.5 & 54.7 & 72.9 & 109.4 & 145.8 \\
\hline \multicolumn{7}{|l|}{ (\% net average earnings) } \\
\hline Gross replacement rate & 56.7 & 56.7 & 56.7 & 56.7 & 56.7 & 56.7 \\
\hline \multicolumn{7}{|l|}{ (\% individual gross earnings) } \\
\hline Net replacement rate & 71.7 & 66.4 & 70.6 & 72.9 & 75.4 & 76.7 \\
\hline \multicolumn{7}{|l|}{ (\% individual net earnings) } \\
\hline Gross pension wealth & 8.8 & 8.8 & 8.8 & 8.8 & 8.8 & 8.8 \\
\hline (multiple of individual gross earnings) & 10.7 & 10.7 & 10.7 & 10.7 & 10.7 & 10.7 \\
\hline Net pension wealth & 8.8 & 8.8 & 8.8 & 8.8 & 8.8 & 8.8 \\
\hline (multiple of individual gross earnings) & 10.7 & 10.7 & 10.7 & 10.7 & 10.7 & 10.7 \\
\hline
\end{tabular}


Pension modelling results: Slovak Republic, pre-reform scenario

\begin{tabular}{lc|ccccc}
\hline \multirow{2}{*}{$\begin{array}{l}\text { Men } \\
\text { Women (where different) }\end{array}$} & \multicolumn{5}{|c}{ Individual earnings, multiple of economy-wide average } \\
\hline & & 0.5 & 0.75 & 1 & 1.5 & 2 \\
\hline Gross relative pension level & 55.3 & 32.5 & 48.8 & 59.5 & 59.5 & 59.5 \\
(\% average gross earnings) & 52.7 & 31.0 & 46.5 & 59.5 & 59.5 & 59.5 \\
Net relative pension level & 71.0 & 41.8 & 62.7 & 76.4 & 76.4 & 76.4 \\
(\% net average earnings) & 67.7 & 39.8 & 59.8 & 76.4 & 76.4 & 76.4 \\
& & & & & & 29.7 \\
Gross replacement rate & 65.0 & 65.0 & 65.0 & 59.5 & 39.6 & 29.7 \\
(\% individual gross earnings) & 62.0 & 62.0 & 62.0 & 59.5 & 39.6 & 40.2 \\
Net replacement rate & 82.1 & 76.1 & 80.9 & 76.4 & 52.7 & 40.2 \\
(\% individual net earnings) & 78.3 & 72.5 & 77.2 & 76.4 & 52.7 & 5.8 \\
& & & & & & 7.8 \\
Gross pension wealth & 12.8 & 12.8 & 12.8 & 11.7 & 7.8 & 8.0 \\
(multiple of individual gross earnings) & 16.7 & 16.7 & 16.7 & 16.1 & 10.7 & 5.8 \\
Net pension wealth & 12.8 & 12.8 & 12.8 & 11.7 & 7.8 & 8.0 \\
(multiple of individual gross earnings) & 16.7 & 16.7 & 16.7 & 16.1 & 10.7 & \\
\hline
\end{tabular}




\section{Spain}

$\mathrm{T}$

he Spanish public pension system consists of a single, earnings-related benefit. There is also a means-tested minimum pension, which replaces the previous special social assistance scheme.

\section{Qualifying conditions}

The retirement age for a full benefit is 65 years for men and women. 15 years of contributions are necessary to qualify for a pension benefit.

\section{Benefit calculation}

\section{Earnings-related}

The benefit accrues according to a schedule. After 15 years' contributions, it is $50 \%$ of the earnings base. Over the next ten years, an extra 3\% is accrued per year, followed by $2 \%$ per year thereafter. The maximum accrual is $100 \%$, reached after 35 years' contributions.

The earnings base is pay over the last 15 years, up-rated in line with prices, apart from the last two years. This means that the replacement rate relative to final salary is less than $100 \%$. On the standard assumptions for earnings growth and price inflation, this is calculated to be $88 \%$.

There is a ceiling to earnings for contributions and benefit purposes of EUR 32778 , corresponding to $165 \%$ of average earnings.

Benefits are price-indexed.

\section{Minimum}

There is a minimum pension payable from age 65 amounting to EUR 417.81 per month, or $30 \%$ of average earnings, for pensioners without a dependent spouse. There are 14 payments per year.

\section{Early retirement}

Early retirement is available from age 61 for people entering the system in 1967 or later who are unemployed, provided they have contributed for at least 30 years. The actuarial reduction depends on the number of years of contributions: $8 \%$ (30 years), 7.5\% (31-34 years), $7 \%$ (35-37 years), $6.5 \%$ (38-39 years), and 6\% for more than 40 years of contributions.

For people who entered the system before 1967, early retirement was possible from age 60.

The minimum pension for early retirees is EUR 389.31 or $27 \%$ of average earnings, and after 65 it moves to the higher level.

Between 60 and 64, it is possible to combine partial pension receipt and a part-time job, if working hours are reduced between $25 \%$ and $85 \%$. Another employee must replace the remaining working hours left by the partial pensioner. 


\section{Late retirement}

It is possible to defer the pension after normal retirement age. For people with 65 years and 35 years of contributions, the amount of the pension may exceed $100 \%$ of the calculation base. The benefit increases by $2 \%$ per year of deferral.

From 65 there is also the possibility of combining partial pension and part-time job. In this case, there is no obligation to replace the working hours.

\section{Pension modelling results: Spain}
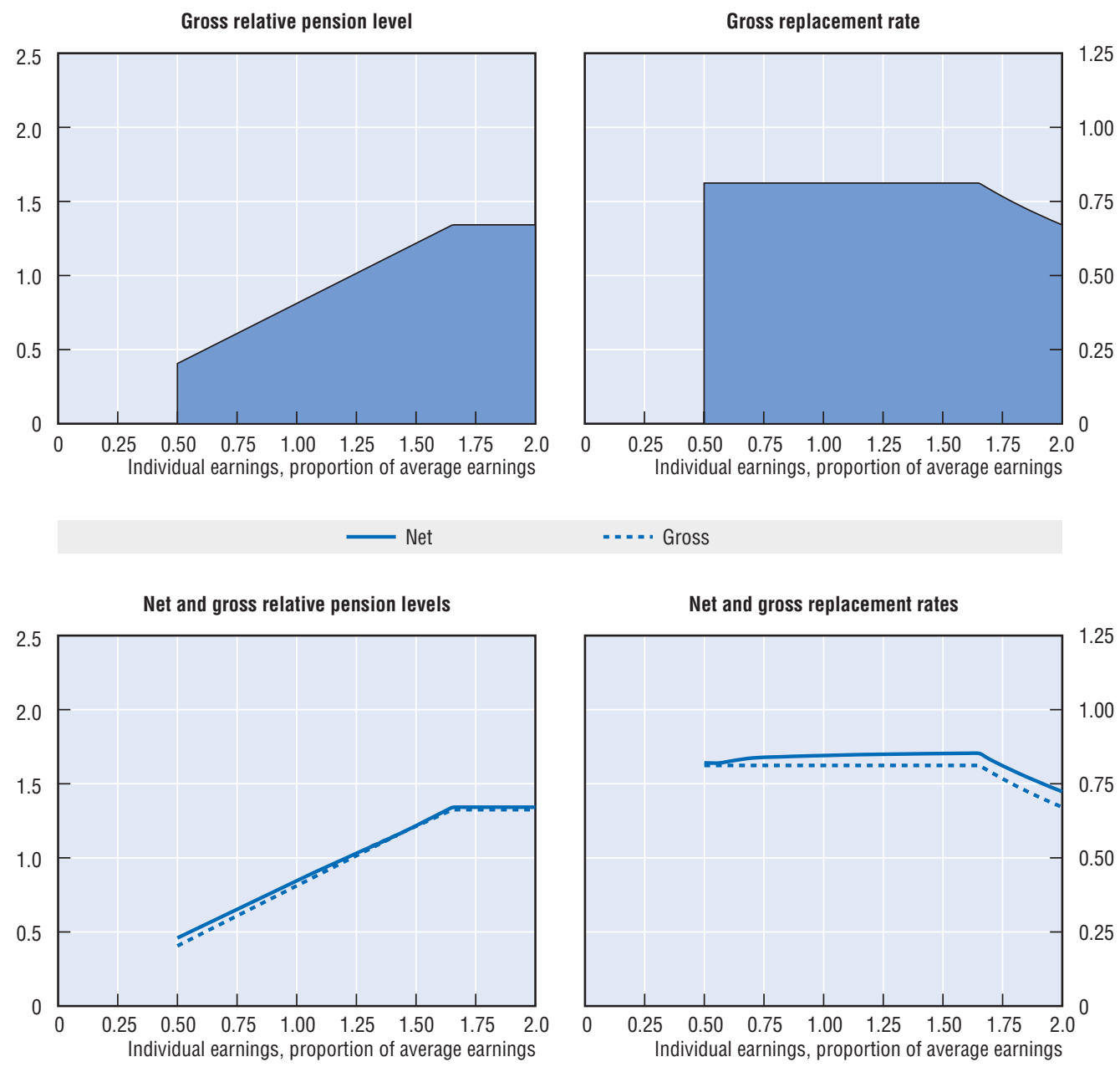


\begin{tabular}{|c|c|c|c|c|c|c|}
\hline \multirow{2}{*}{$\begin{array}{l}\text { Men } \\
\text { Women (where different) }\end{array}$} & \multirow{2}{*}{ Median earner } & \multicolumn{5}{|c|}{ Individual earnings, multiple of economy-wide average } \\
\hline & & 0.5 & 0.75 & 1 & 1.5 & 2 \\
\hline Gross relative pension level & 69.0 & 40.6 & 60.9 & 81.2 & 121.8 & 134.2 \\
\hline \multicolumn{7}{|l|}{ (\% average gross earnings) } \\
\hline Net relative pension level & 73.0 & 46.0 & 65.2 & 84.5 & 121.3 & 132.5 \\
\hline \multicolumn{7}{|l|}{ (\% net average earnings) } \\
\hline Gross replacement rate & 81.2 & 81.2 & 81.2 & 81.2 & 81.2 & 67.1 \\
\hline \multicolumn{7}{|l|}{ (\% individual gross earnings) } \\
\hline Net replacement rate & 84.2 & 82.0 & 83.9 & 84.5 & 85.2 & 72.4 \\
\hline \multicolumn{7}{|l|}{ (\% individual net earnings) } \\
\hline Gross pension wealth & 12.2 & 12.2 & 12.2 & 12.2 & 12.2 & 10.1 \\
\hline (multiple of individual gross earnings) & 14.3 & 14.3 & 14.3 & 14.3 & 14.3 & 11.8 \\
\hline Net pension wealth & 10.3 & 11.0 & 10.4 & 10.1 & 9.7 & 7.9 \\
\hline (multiple of individual gross earnings) & 12.1 & 12.9 & 12.2 & 11.9 & 11.4 & 9.3 \\
\hline
\end{tabular}




\section{Sweden}

$\mathrm{T}_{\mathrm{l}}$ he new pension system, introduced in 1999, applies to people born in 1954 and after. The old and the new systems will cover older workers proportionally: people born 1938-1953 will receive pensions under a mix of the old and new rules. The earnings-related part is based on notional accounts and there is a small mandatory contribution to individual, defined-contribution funded pensions. There is also a pension-income-tested top-up. Occupational pension plans - with defined-benefit and defined-contribution elements have broad coverage.

\section{Qualifying conditions}

Eligibility for the guarantee pension will be earned with three years' residency. It is possible to get a guarantee pension from age 65 .

Maximum guarantee pension is earned with 40 years' residency and is reduced proportionally for shorter periods. The pension can be claimed from age 65 .

The standard pension age in the occupational plan for white-collar private workers (the ITP plan) is 65, with an early pension age of 55 . There is a minimum entry age of 28.

\section{Benefit calculation}

\section{Earnings-related}

The new earnings-related scheme uses notional accounts. Contributions of $16 \%$ of pensionable pay are credited and then up-rated in line with a three-year moving average of economy-wide average earnings. Pensionable pay is defined as earnings less the employee contribution to the pension system (i.e. to both the notional accounts and the premium pension) of $7 \%$ of gross earnings, giving an effective contribution rate on gross earnings of $14.88 \%$ to the notional-accounts system. Contributions are only levied when annual earnings exceed a small floor of SEK 16600 in 2004, less than 5\% of average earnings, although they are due on the whole of earnings for all people earning above the floor. There is a ceiling to benefits calculated in terms of pensionable earnings of SEK 317500 in 2004. However, this again relates to pensionable earnings, giving an effective ceiling relative to gross earnings of SEK 341400 in 2004 (around 130\% of average earnings). Employer contributions are also paid only to the ceiling, but there is an additional tax on earnings above the ceiling. This tax has the same percentage as the pension contribution but goes directly to the central government budget. It does not accrue any pension rights.

The notional accounts are increased every year by the distribution of the pension balances of deceased persons of the same age as the survivors (inheritance gains). The inheritance gains from people who die before the earliest possible retirement age (61 years) are those actually arising. After this age the inheritance gains factor is estimated on the basis of the mortality observed for an earlier period (computed from five year unisex mortality tables).

At retirement, the accumulated notional capital will be converted to an annuity. This calculation will use a coefficient dependent on individual retirement age and contemporaneous life expectancy (based on the previous five year unisex mortality tables). A real discount rate of $1.6 \%$ a year will be assumed in this calculation. Illustrative values for the annuity coefficient at age 65 are 15.4 for 2000 rising to 16.8 by 2020 and 17.4 by 2040 . 
The annuity coefficient is currently 18.0 for retirement at 61 and 12.8 at age 70 for people born in 1940.

After retirement, pensions are uprated with the increase in nominal average earnings less the imputed interest rate in the annuity divisor of $1.6 \%$.

There is also a "balance mechanism": if assets (the buffer fund plus the estimated value of assets in the form of contribution revenues) fall below liabilities (accrued notional pension capital and capital value of outgoing pensions), then indexation of pensions in payment and returns credited to notional accounts are reduced by the ratio of assets to liabilities. The balancing ratio is now close to the point at which the automatic balancing mechanism would be activated (1.0097 in 2003, 1.0014 in 2004 and 1.0044 in 2005). (The balance ratio for year $t$ is used to calculate the balance number or the need for activating the balancing mechanism in year $t+2$. An activated balancing mechanism would mean lower replacement rates from the national system but could also produce higher results when the pension system recovers and the balance figure increases (the balance index can exceed the income index during the recovery period).

For modelling purposes, the annuity coefficients are calculated using the above rules and the relevant mortality data from the UN/World Bank population database. It is assumed that the balance mechanism does not affect the uprating of benefits.

\section{Minimum}

The "guarantee pension" is an income-tested top-up for people with low levels of benefit from notional accounts. For a single person, the guaranteed benefit in 2004 was SEK 83709 for a single pensioner born after 1938 or 33\% of gross average earnings.

The guarantee pension is withdrawn at 100\% against the first SEK 49518 (2004) of income, for a single person, from the earnings-related pension, thereafter at $48 \%$. This threshold is equivalent to $20 \%$ of average earnings. Only when earnings-related pension exceeds SEK 120651 - nearly 50\% of average earnings - is entitlement to the guarantee exhausted.

The guarantee level is price indexed under current legislation. However, the baseline assumption in the modelling for all countries is that the value of safety-net retirement benefits will, over time, tend to track average earnings rather than decline relative to general living standards.

There is also a housing benefit that covers $93 \%$ of housing costs up to a maximum of SEK 5000 per month for a single pensioner. The benefit is an important part of the minimum living standard for Swedish pensioners. This means-tested benefit is not included in the modelled calculations.

\section{Defined contribution}

A further $2.5 \%$ of pensionable income (giving an effective contribution rate against gross earnings of $2.325 \%$ ) will be paid into personal pension accounts: the premium pension. People have a broad choice of where these funds are invested.

At retirement, people have a choice over the way benefits are withdrawn. First, people can convert the pension into an annuity to avoid investment risk. Alternatively, people will be able to choose a variable annuity, where their funds continue to be invested by their chosen fund manager. These annuities do not have a guaranteed value. The principle of the pension calculation in this case is that the value of the account is divided by an annuity 
divisor (based on estimated average life expectancy) and the pension benefit is credited with an estimated future interest rate of $3 \%$ minus administrative costs. If returns exceed $3 \%$, then either an additional payment is made or the balance of the account is higher and so, therefore, is the base for calculating the annual pension.

\section{Quasi-mandatory occupational}

The occupational schemes together are estimated to cover almost $90 \%$ of employees. There are only four major occupational schemes. The modelling uses the ITP scheme for white-collar workers, which mixes defined-benefit and defined-contribution elements.

The defined benefit is $10 \%$ of final salary on earnings up to a ceiling specified as 7.5 times the income base amount or SEK 317250 in 2004. However, this threshold is in practice lower than the effective ceiling to the public scheme because it applies to gross earnings rather than pensionable earnings. Between this threshold and around 3.1 times average earnings, the full-career replacement rate is $65 \%$; and from around 3.1 to 4.6 times average earnings, $32.5 \%$. A full pension is earned with 30 years' contributions from an entry age of 28. Shorter tenures result in a proportionally reduced benefit.

Pensions in payment are adjusted at the discretion of the ITP board. However, recent increases have been broadly in line with price inflation and so this procedure is assumed in the modelling.

The ITP also has a defined-contribution component, which receives a contribution of $2 \%$ of gross earnings. The modelling assumes that this is withdrawn at the normal pension age in the form of a price-indexed annuity. The entry age is again 28.

The ITP plan has been recently renegotiated and the new scheme applies to those born 1979 or later. The new scheme is a defined-contribution with a contribution of $4.5 \%$ of gross earnings up to 7.5 income base amounts (SEK 333750 in 2006) and 30\% of gross wages above this limit. This system has not been modelled in the calculations.

\section{Early retirement}

Retirement is possible from age 61 in the public pension scheme (both the income pension and the premium pension). There is no fixed retirement age. The notionalaccounts and annuity calculations provide an automatic actuarial reduction depending on the age of retirement.

The income-tested guarantee pension cannot be claimed before 65 . If the notionalaccounts pension is withdrawn before or after age 65 , the guarantee pension is still calculated as if the notional-accounts pension had been withdrawn at age 65 .

It is possible to draw the ITP occupational pension from age 55 . There is a reduction in benefits for pensions claimed before age 62. For retirement at 62 or above, the full occupational pension is paid as if contributions were paid until age 65 , though reduced by $0.5 \%$ per month that the pension is withdrawn earlier than the age of 65 .

\section{Late retirement}

It is possible to defer the notional accounts pension with no upper age limit, again with automatic actuarial adjustments.

It is possible to defer the ITP occupational pension after age 65 . No additional pension rights can be accrued after age 65 . 
It is possible to combine work and pension receipt. Pensions can be withdrawn partially (at 25,50 or $75 \%$ of the full pension). The guarantee pension is adjusted against other pensions from the Swedish old-age pension system and from comparable foreign national pensions, but is not reduced by wage income, capital income, occupational pension or private pension insurance. Thus, it is also possible to combine work with receipt of the guarantee pension.

\section{Pre-reform scenario}

The reform of the public pension system was introduced in 1999. The coverage of the old and new systems is described above.

The old system had two tiers. The first was a basic pension subject to residency (40 years) or contributions (30 years) with proportional reductions if the number of years fell short of the requirement. The pension value for a single person was $96 \%$ of the price base amount, the latter being SEK 39300 in 2004. The price base amount is indexed to prices.

The earnings-related tier was based on a points system. Pension receipt required at least three years' contributions. The pension value was $60 \%$ of the base amount (at the time of reaching pension age) multiplied by the average number of points in the 15 years with the highest points. In turn, the number of points was defined as earnings less the contemporaneous base amount divided by the contemporaneous base amount. (Note that since the base amount was price indexed and the formula depended on both the contemporaneous and the final base amount, then this policy is equivalent to prices valorisation.) The ceiling to pensionable earnings was 7.5 price base amounts. A full pension required 30 years of contributions with proportional reductions for shorter contribution histories. Pensions in payment under the pre-reform system were indexed to prices. Early (to 61) and late (to 70) retirement was possible with adjustments. These were $0.5 \%$ per month (6\% per year) for early retirement and $0.7 \%$ per month $(8.4 \%$ per year) for late retirement.

The pre-reform pension system also had a pension supplement, payable to those with little or no earnings-related pension. This was 0.56 price base amounts (SEK 21565 in 2002). It was withdrawn against the earnings-related pension (not other sources of income).

As part of the reform package introducing the guarantee pension, tax concessions for older people were withdrawn. In 2002, older people were entitled to a special income-tax deduction of between SEK 11104 and SEK 59688 (depending on pension income). This extra deduction was withdrawn at $66.5 \%$ of income above the minimum pension level, implying no special deduction for pensioners with incomes above SEK 132605. 


\section{Pension modelling results: Sweden}

$\square$ DC(OP) $\quad \square$ Occupational $\quad \square$ DC $\quad \square$ Earnings-related $\quad \square$ Minimum
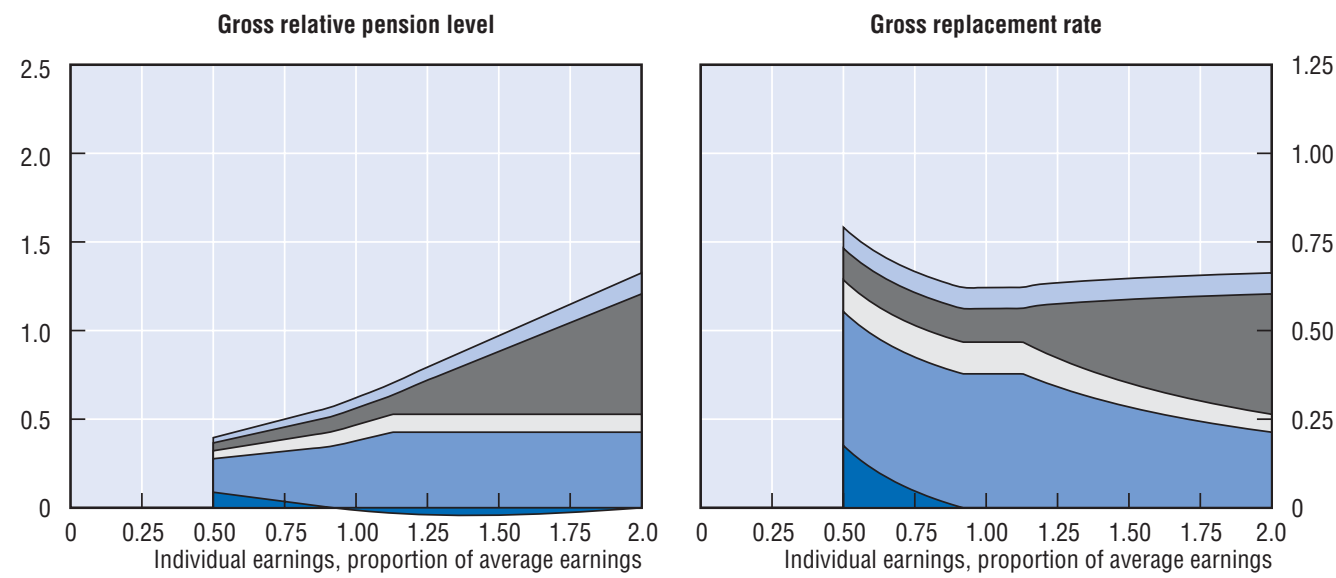

- Net

. . ... Gross
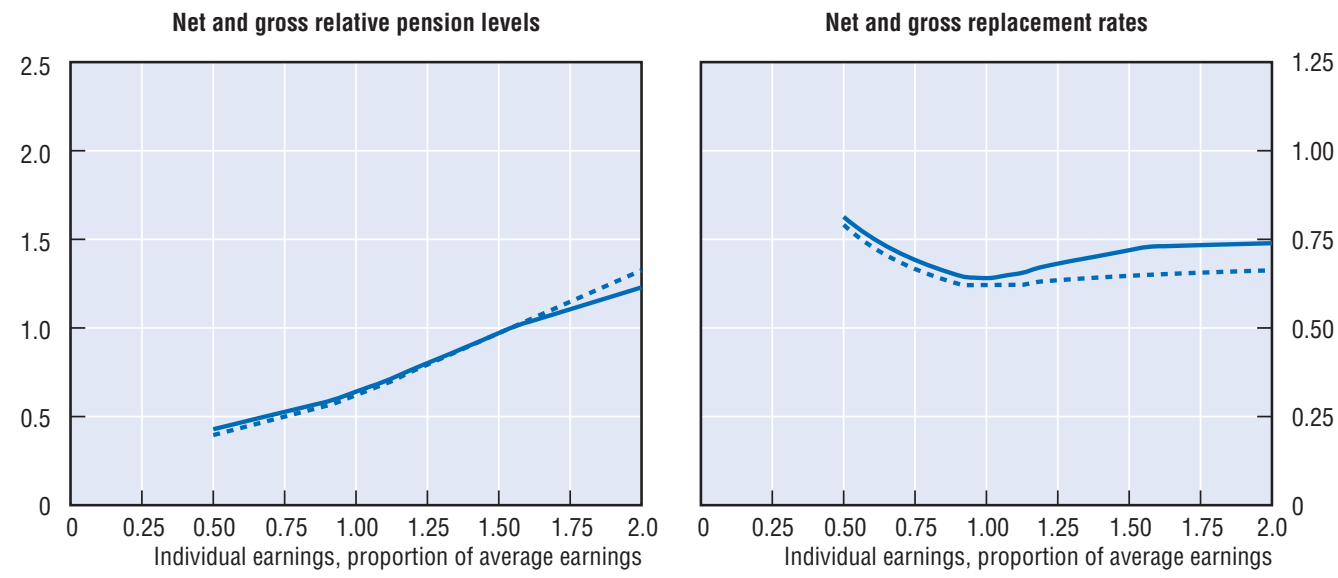

\begin{tabular}{|c|c|c|c|c|c|c|}
\hline \multirow{2}{*}{$\begin{array}{l}\text { Men } \\
\text { Women (where different) }\end{array}$} & \multirow{2}{*}{ Median earner } & \multicolumn{5}{|c|}{ Individual earnings, multiple of economy-wide average } \\
\hline & & 0.5 & 0.75 & 1 & 1.5 & 2 \\
\hline Gross relative pension level & 54.2 & 39.6 & 50.0 & 62.1 & 97.1 & 132.5 \\
\hline \multicolumn{7}{|l|}{ (\% average gross earnings) } \\
\hline Net relative pension level & 56.6 & 42.8 & 52.7 & 64.0 & 97.1 & 122.9 \\
\hline \multicolumn{7}{|l|}{ (\% net average earnings) } \\
\hline Gross replacement rate & 63.7 & 79.1 & 66.6 & 62.1 & 64.7 & 66.3 \\
\hline \multicolumn{7}{|l|}{ (\% individual gross earnings) } \\
\hline Net replacement rate & 66.2 & 81.4 & 69.2 & 64.0 & 71.9 & 73.9 \\
\hline \multicolumn{7}{|l|}{ (\% individual net earnings) } \\
\hline Gross pension wealth & 10.2 & 12.6 & 10.7 & 10.0 & 10.3 & 10.5 \\
\hline (multiple of individual gross earnings) & 11.7 & 14.4 & 12.2 & 11.4 & 11.8 & 12.0 \\
\hline Net pension wealth & 7.4 & 9.5 & 7.8 & 7.2 & 7.2 & 6.8 \\
\hline (multiple of individual gross earnings) & 8.5 & 10.9 & 9.0 & 8.2 & 8.2 & 7.8 \\
\hline
\end{tabular}


Pension modelling results: Sweden, pre-reform scenario

\begin{tabular}{|c|c|c|c|c|c|c|}
\hline \multirow{2}{*}{$\begin{array}{l}\text { Men } \\
\text { Women (where different) }\end{array}$} & \multirow{2}{*}{ Median earner } & \multicolumn{5}{|c|}{ Individual earnings, multiple of economy-wide average } \\
\hline & & 0.5 & 0.75 & 1 & 1.5 & 2 \\
\hline Gross relative pension level & 67.7 & 41.5 & 60.2 & 78.9 & 115.1 & 150.6 \\
\hline \multicolumn{7}{|l|}{ (\% average gross earnings) } \\
\hline Net relative pension level & 69.2 & 44.7 & 62.2 & 79.8 & 110.8 & 135.5 \\
\hline \multicolumn{7}{|l|}{ (\% net average earnings) } \\
\hline Gross replacement rate & 79.6 & 83.1 & 80.3 & 78.9 & 76.8 & 75.3 \\
\hline \multicolumn{7}{|l|}{ (\% individual gross earnings) } \\
\hline Net replacement rate & 81.0 & 84.9 & 81.8 & 79.8 & 82.0 & 81.5 \\
\hline \multicolumn{7}{|l|}{ (\% individual net earnings) } \\
\hline Gross pension wealth & 12.5 & 13.0 & 12.6 & 12.3 & 12.0 & 11.8 \\
\hline (multiple of individual gross earnings) & 14.2 & 14.8 & 14.3 & 14.1 & 13.7 & 13.4 \\
\hline Net pension wealth & 8.9 & 9.8 & 9.1 & 8.7 & 8.1 & 7.4 \\
\hline (multiple of individual gross earnings) & 10.1 & 11.1 & 10.3 & 9.9 & 9.2 & 8.4 \\
\hline
\end{tabular}




\section{Switzerland}

$\mathrm{T}_{\mathrm{r}}$ he Swiss pension system has three main parts. The public scheme is earnings-related, but has a progressive formula. There is also a system of mandatory occupational pensions and an income-tested supplementary benefit.

\section{Qualifying conditions}

Pensionable age under the public scheme and mandatory occupational pensions is currently 65 for men and 63 for women, although the latter will increase to 64 from 2005. A full pension requires contributions for 44 years.

\section{Benefit calculation}

\section{Earnings-related}

The public pension is based on average lifetime earnings. If this figure is less than CHF 37 980, then the entitlement is CHF 9368 plus 26\% of average lifetime earnings. For lifetime earnings above the threshold, the entitlement is a flat CHF 13166 plus 16\% of average lifetime earnings.

There is a minimum pension of CHF 12660 and a maximum pension of twice that level. These are equivalent to 18 and $36 \%$ of average earnings, respectively. The maximum benefit is reached when average lifetime earnings are CHF 75960 , equivalent to $108 \%$ of economy-wide average earnings.

Pensions in payment are indexed $50 \%$ to prices and $50 \%$ to nominal earnings.

\section{Mandatory occupational}

The system of mandatory occupational pensions was introduced in 1985. It is built around "defined credits" to an individual's pension account. These vary by sex and age:

\begin{tabular}{lcccc}
\hline Men, of age & $25-34$ & $35-44$ & $45-54$ & $55-64$ \\
Women, of age & $25-31$ & $32-41$ & $42-51$ & $52-63$ \\
Credit (\% of co-ordinated earnings) & 7 & 10 & 15 & 18 \\
\hline
\end{tabular}

The value of accumulated credits at retirement naturally depends on the interest rate applied to earlier years' contributions. For a long period, until the end of 2002, there was a minimum rate of $4 \%$. It was cut to $3.25 \%$ in 2003 and to $2.25 \%$ in 2004 . If the interest rate is broadly equivalent to the growth rate of earnings, then a full career in the system will give a man at age 65 accumulated credits of $500 \%$ of earnings. However, higher (or lower) outcomes are possible if the interest rate exceeds (is less than) growth in earnings. The modelling assumes that the interest rate applied to the credits will be equivalent to the growth rate of earnings over the long term.

The system has a minimum annuity rate of $7.2 \%$ that is applied to this notional capital sum. This gives a full career replacement rate of $(500 \times 7.2=) 36 \%$ (subject to the interest rate being equal to earnings growth). From 2005, the minimum annuity rate is being reduced over a ten-year period, eventually reaching $6.8 \%$. 
The defined credits (and hence the replacement rate) apply only to "co-ordinated" earnings. This is pay between the maximum pension of the public scheme (CHF 25320 for 2004) and three times that level (CHF 75960 for 2004). These thresholds are equivalent to $36 \%$ and $108 \%$ of average earnings. Note that the ceiling for pensionable pay is the same in the public scheme and in the mandatory occupational pension schemes. There is a minimum for co-ordinated earnings of one eighth of the maximum value. Credits accrue at this minimum level for people with co-ordinated earnings below this level.

The range of co-ordinated earnings is being extended. The entry level in 2005 is reduced to three-quarters of its previous level. This is included in the modelling.

\section{Targeted}

The supplementary benefit scheme aims to give a minimum pension income to single people of at least CHF 17300 , equivalent to $24 \%$ of average earnings. The supplementary benefit is indexed in the same way as the public old age pensions, i.e. to a mixed index of $50 \%$ prices and $50 \%$ wages. There are discretionary cantonal additions for low-income pensioners; these are disregarded in the model.

\section{Early retirement}

Early retirement in the public scheme is possible two years before the standard retirement age, i.e. from age 63 for men and 62 for women as of 2005 . For each year that the pension is claimed early, it is reduced by $6.8 \%$ from the full value. This is equivalent to an actuarial adjustment, as operated in other countries, of $4.5 \%$ (since $1 / 44=2.3 \%$ of the adjustment reflects the additional year that the member has contributed).

For women born in 1947 or before, the reduction in pension benefits from their full value is $3.4 \%$ per year of early retirement.

Early retirement is permitted in the occupational schemes. In practice, schemes may allow retirement up to five years before the normal age, although schemes can decide on their own policy. Generally, the statutory annuity rate is reduced from the $7.2 \%$ at age 65 , by 0.2 percentage points per year of early retirement. (Note that this conversion rate will fall gradually to $6.8 \%$ over the ten years starting in 2005.) The 0.2 percentage point reduction is equivalent to an actuarial adjustment, as conventionally measured, of 2.9-3.2\% per year of early retirement (increasing with the extent of early retirement). Including also the loss of contributions and credits as a result of early retirement, the benefit is $6.7-8.8 \%$ lower per year of early retirement. The loss increases the earlier that retirement is taken. (The range given is from age 61 to age 65.)

\section{Late retirement}

Both public and occupational pensions can be deferred after normal pension age. Pensions are adjusted in the same way as for early retirement. The pension can be deferred for up to five years after the normal pension age. The pension is increased according to the following schedule:

\begin{tabular}{|c|c|c|c|c|c|}
\hline Deferral & 1 year & 2 years & 3 years & 4 years & 5 years \\
\hline Adjustment & $5.2 \%$ & $10.8 \%$ & $17.1 \%$ & $24.0 \%$ & $31.5 \%$ \\
\hline
\end{tabular}

It is also possible to claim the public pension at 65 and continue working. 
Contributions are not levied on people working after age 65 if earnings are below CHF 16800 per year (2004). For earnings above that level, contributions are levied when people defer the pension or claim the pension while continuing their work, but no additional pension entitlement can be earned.

In the occupational plans, the annuity rate is increased by 0.2 percentage points for each year that retirement is deferred. The authorities, in practice, allow deferral for up to five years

In principle, it is possible to combine receipt of the occupational pension with work. In practice, these are mainly cases of people with incomplete careers or people who have retired early rather than late. Therefore, the modelling assumes that people defer their occupational pension if they continue to work after the normal pension age. People do not continue to contribute after 65 under the public pension scheme.

\section{Pension modelling results: Switzerland}
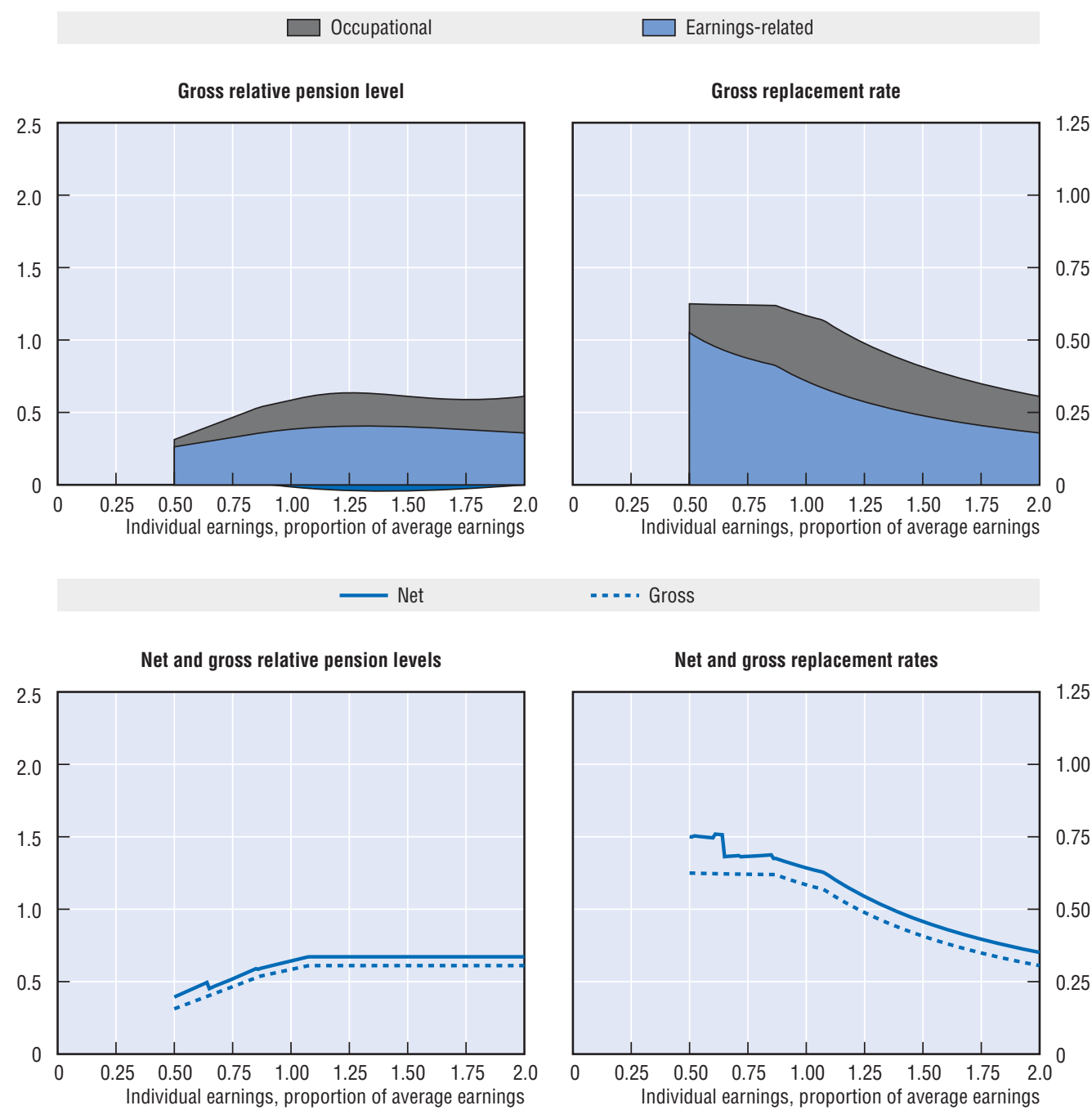


\begin{tabular}{|c|c|c|c|c|c|c|}
\hline \multirow{2}{*}{$\begin{array}{l}\text { Men } \\
\text { Women (where different) }\end{array}$} & \multirow{2}{*}{ Median earner } & \multicolumn{5}{|c|}{ Individual earnings, multiple of economy-wide average } \\
\hline & & 0.5 & 0.75 & 1 & 1.5 & 2 \\
\hline Gross relative pension level & 52.7 & 31.2 & 46.6 & 58.4 & 61.1 & 61.1 \\
\hline (\% average gross earnings) & 53.2 & 31.4 & 47.0 & 59.1 & 61.8 & 61.8 \\
\hline Net relative pension level & 59.0 & 39.4 & 51.9 & 64.3 & 67.2 & 67.2 \\
\hline (\% net average earnings) & 58.4 & 39.6 & 52.4 & 65.0 & 68.0 & 68.0 \\
\hline Gross replacement rate & 62.0 & 62.5 & 62.1 & 58.4 & 40.7 & 30.5 \\
\hline (\% individual gross earnings) & 62.6 & 62.8 & 62.6 & 59.1 & 41.2 & 30.9 \\
\hline Net replacement rate & 68.8 & 75.0 & 68.2 & 64.3 & 45.7 & 35.1 \\
\hline (\% individual net earnings) & 68.1 & 75.4 & 68.9 & 65.0 & 46.3 & 35.5 \\
\hline Gross pension wealth & 10.5 & 10.7 & 10.5 & 9.8 & 6.8 & 5.1 \\
\hline (multiple of individual gross earnings) & 12.8 & 13.1 & 12.9 & 12.0 & 8.3 & 6.3 \\
\hline Net pension wealth & 8.8 & 10.1 & 8.8 & 8.1 & 5.6 & 4.2 \\
\hline (multiple of individual gross earnings) & 10.5 & 12.4 & 10.8 & 9.9 & 6.9 & 5.2 \\
\hline
\end{tabular}




\section{Turkey}

$\mathrm{T}$ urkey has an earnings-related public scheme with an income-tested safety net and a flat-rate supplementary pension.

\section{Post-reform system}

\section{Qualifying conditions}

The minimum pension age for men retiring in 2004 is 45 and 40 for women. An earlier pension reform proposed increases in the age so that it would reach 60 for men and 58 for women in the late 2030s. The most recent reform includes further increases to 65 for men retiring in 2043 and for women retiring slightly later. The modelling uses the long-term pension age.

The means-tested pension is payable only to those who have no other social security rights and who are either older than 65 or older than 18 and disabled.

\section{Benefit calculation}

\section{Earnings-related}

Benefits accrue at a rate of $2.5 \%$ of the earnings measure per annum until the end of 2015; thereafter the accrual rate will be $2 \%$ per annum. The model uses the long-term accrual rate of $2 \%$. The earnings measure is based on lifetime average earnings, re-valued with an index composed of 50\% real earnings growth and $50 \%$ price inflation.

Pensions in payment are indexed to prices.

\section{Minimum}

There is a minimum pension, which was TRY 364.7 million at the beginning of 2004 and TRL 400.7 million at the end, corresponding to about one third of average earnings.

\section{Targeted}

The means-tested pension is paid quarterly. For the first half of 2002 the pension was TRY 54.6 million per month, for the second, pension was TRY 57.9 million per month or about $5 \%$ of average earnings.

A monthly supplement is paid to all retirees. Its value started the year 2003 at TRY 75 million. As the monthly increases are awarded to individuals' earnings-related pensions this supplement is reduced by the amount of those increases. In 2004, there was no such supplement.

There was an increase in Consumer Price Index in 2003 by $18.4 \%$ and subsequently, all pensions in payment were increased by $10 \%$ in January 2004, and 10\% in July 2004 .

\section{Early retirement}

Workers in specific industries (e.g. mining) and people with disability can retire early but other workers cannot claim pensions before the eligibility ages. 


\section{Late retirement}

It is possible to defer the pension beyond the normal pension age, but the amount of pension benefit is not adjusted to the longer period of contributions. However from 2006, the extended contribution will be reflected.

\section{Pre-reform scenario}

\section{Qualifying conditions}

Recent entrants (from September 1999) can draw a pension from age 60 (men) or 58 (women) with 7000 days of contributions. This is equivalent to around 20 years of contributions for continuous employment. An alternative eligibility condition is 25 years of insurance coverage with 4500 days of contributions but the pension could be claimed at 60 for men and 58 for women.

\section{Benefit calculation}

The pension is based on average lifetime earnings revalued in line with GDP growth. For consistency with the modelling for other countries, it is again assumed that real earnings grow at $2 \%$ a year. Given projected labour-force growth of $1 \%$ a year over the next 50 years, it is assumed that annual real GDP growth will be $3 \%$.

The pension has a non-linear formula with years of coverage. The first 3600 days of contributions earn a pension of $35 \%$ of pay, with $2 \%$ per year extra until 9000 days of contributions and $1.5 \%$ per year thereafter.

There is a floor above which contributions are required. This had two different values during calendar 2004: TRY 549.6 million from January to June 2004, TRY 444.1 million from July onwards. Minimum pensionable earnings were higher than the minimum wage in the earlier period while the two values were the same from July.

There is a ceiling to pensionable earnings; its value was TRY 2748.1 million from January to June 2004 and TRY 2886.9 million from July onwards. After the reform started in 1999, the ceiling was only three times minimum wage but it is raised to five times in April 2000.

The modelling uses the average of the variables above for the calendar year 2004.

Indexation of pensions in payment is to the consumer price index. Pensions are adjusted monthly. However, in the past two years additional, real increases in pensions have been granted and in one year a "social supplement" was added. The modelling assumes price indexation of pensions in payment.

The minimum pension and targeted pension were described above.

\section{Further reading}

Brook, A.-M. and E.R. Whitehouse (2006), "The Turkish Pension System: further reforms to help solve the informality problem", Social, Employment and Migration Working Paper No. 44, OECD, Paris (also available as Working Paper No. 529, Economics Department, OECD.)

OECD (2006), "Making the Pension System Less of an Obstacle to Formalisation", Chapter 4 of OECD Economic Surveys: Turkey, Paris. 


\section{Pension modelling results: Turkey}
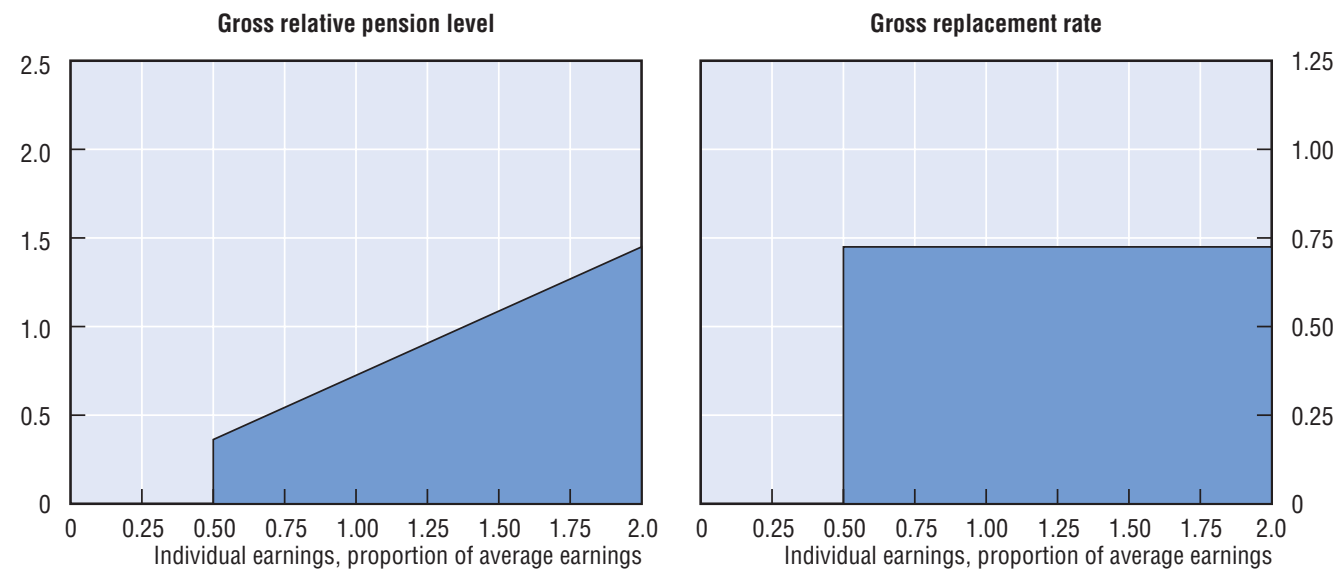

Net

..... Gross

Net and gross relative pension levels

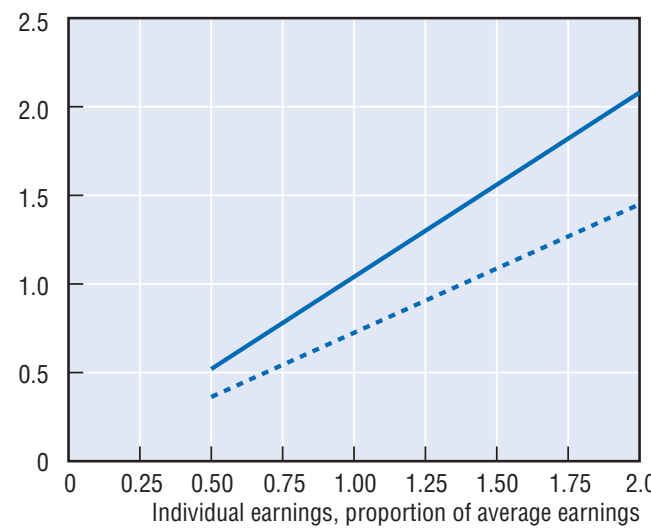

Net and gross replacement rates

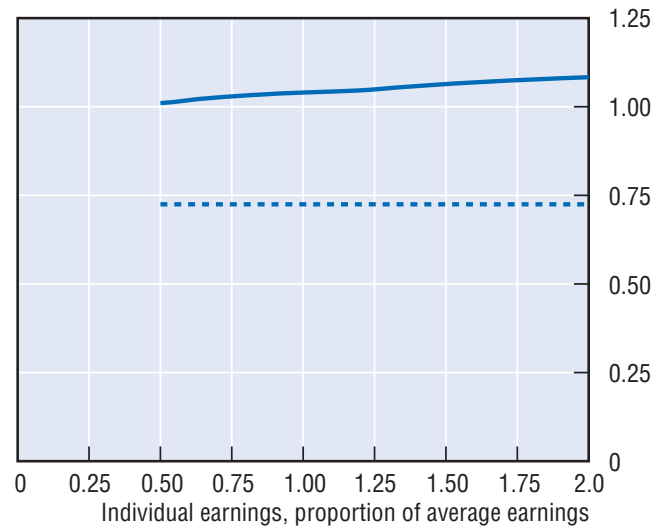

\begin{tabular}{|c|c|c|c|c|c|c|}
\hline \multirow{2}{*}{$\begin{array}{l}\text { Men } \\
\text { Women (where different) }\end{array}$} & \multirow{2}{*}{ Median earner } & \multicolumn{5}{|c|}{ Individual earnings, multiple of economy-wide average } \\
\hline & & 0.5 & 0.75 & 1 & 1.5 & 2 \\
\hline \multicolumn{7}{|l|}{ (\% average gross earnings) } \\
\hline Net relative pension level & 88.4 & 52.0 & 78.0 & 104.0 & 156.0 & 208.0 \\
\hline \multicolumn{7}{|l|}{ (\% net average earnings) } \\
\hline Gross replacement rate & 72.5 & 72.5 & 72.5 & 72.5 & 72.5 & 72.5 \\
\hline \multicolumn{7}{|l|}{ (\% individual gross earnings) } \\
\hline Net replacement rate & 103.4 & 101.0 & 102.9 & 104.0 & 106.4 & 108.3 \\
\hline \multicolumn{7}{|l|}{ (\% individual net earnings) } \\
\hline (multiple of individual gross earnings) & 10.7 & 10.7 & 10.7 & 10.7 & 10.7 & 10.7 \\
\hline Net pension wealth & 9.2 & 9.2 & 9.2 & 9.2 & 9.2 & 9.2 \\
\hline (multiple of individual gross earnings) & 10.7 & 10.7 & 10.7 & 10.7 & 10.7 & 10.7 \\
\hline
\end{tabular}


Pension modelling results: Turkey, pre-reform scenario

\begin{tabular}{|c|c|c|c|c|c|c|}
\hline \multirow{2}{*}{$\begin{array}{l}\text { Men } \\
\text { Women (where different) }\end{array}$} & \multirow{2}{*}{ Median earner } & \multicolumn{5}{|c|}{ Individual earnings, multiple of economy-wide average } \\
\hline & & 0.5 & 0.75 & 1 & 1.5 & 2 \\
\hline Gross relative pension level & 91.4 & 53.8 & 80.7 & 107.6 & 161.4 & 215.2 \\
\hline (\% average gross earnings) & 87.4 & 51.4 & 77.1 & 102.8 & 154.2 & 205.6 \\
\hline Net relative pension level & 131.2 & 77.2 & 115.8 & 154.4 & 231.6 & 308.8 \\
\hline (\% net average earnings) & 125.4 & 73.8 & 110.6 & 147.5 & 221.3 & 295.0 \\
\hline Gross replacement rate & 107.6 & 107.6 & 107.6 & 107.6 & 107.6 & 107.6 \\
\hline (\% individual gross earnings) & 102.8 & 102.8 & 102.8 & 102.8 & 102.8 & 102.8 \\
\hline Net replacement rate & 153.5 & 150.0 & 152.8 & 154.4 & 157.9 & 160.8 \\
\hline (\% individual net earnings) & 146.7 & 143.3 & 146.0 & 147.5 & 150.9 & 153.7 \\
\hline Gross pension wealth & 16.3 & 16.3 & 16.3 & 16.3 & 16.3 & 16.3 \\
\hline (multiple of individual gross earnings) & 19.1 & 19.1 & 19.1 & 19.1 & 19.1 & 19.1 \\
\hline Net pension wealth & 16.3 & 16.3 & 16.3 & 16.3 & 16.3 & 16.3 \\
\hline (multiple of individual gross earnings) & 19.1 & 19.1 & 19.1 & 19.1 & 19.1 & 19.1 \\
\hline
\end{tabular}




\section{United Kingdom}

B

ritain has a complex pension system, which mixes public and private provision. The public scheme has two tiers, (a flat-rate basic pension and an earnings-related additional pension), which are complemented by a large voluntary private pension sector. Most employee contributors "contract out" of the state second tier into private pensions of different sorts. A new income-related benefit (pension credit) has recently been introduced to target extra public spending on the poorest pensioners.

\section{Qualifying conditions}

Pension age, currently 60 for women and 65 for men, will be equalised at 65 during the period 2010 to 2020 . The eligibility age for the minimum income guarantee/pension credit is 60 , and will increase in line with the women's pension age. The new savings credit is only available from 65 for both men and women.

To qualify for the basic state pension, people need to pay social security contributions or have credits for around nine-tenths of their potential working lives (44 years). A proportionally reduced pension is available for people who do not meet the full condition, but only to a minimum of $25 \%$ (i.e., 11 years).

\section{Benefit calculation}

\section{Basic}

The full basic state pension for a single person was GBP 79.60 per week in 2004/05 (GBP 77.45 in 2003/04 giving an annual total for 2004 of GBP 4111 ), equivalent to $15 \%$ of average earnings.

\section{Earnings-related}

For earnings between the lower earnings limit (GBP 4108 per year in 2004/05 and GBP 4004 in 2003/04) and the first threshold (GBP 11 600, GBP 11 200), the replacement rate is $40 \%$ of the difference. The lower earnings limit is worth $15 \%$ of average earnings while the first threshold is $42 \%$. This also applies to people covered by credits. This is equivalent to treating people earning below the first threshold as if they had earned at this level. Over the next range, the replacement rate is $10 \%$, ending at GBP 26600 , GBP 25600 . Between this threshold and the ceiling, the replacement rate is 20\%. The ceiling was GBP 31720 in 2004/05 and GBP 30940 in 2003/04. The upper threshold is worth around $96 \%$ of average earnings and the ceiling is $115 \%$ of average earnings.

The benefit value is calculated on average lifetime salary, with earlier years' pay uprated in line with average economy-wide earnings. The benefit is then price-indexed after retirement.

\section{Contracting out}

Some $48 \%$ of employees are "contracted out" of the state second pension, into either an occupational plan (provided by an employer), a personal pension or a stakeholder plan (both provided by financial-services companies). Occupational schemes are mainly DB, but there has been rapid growth since the mid-1980s in DC occupational plans, albeit from a very low base. Personal pensions and stakeholder plans are DC. 
A contracted-out employee forgoes some or all of their state second pension entitlement. For employees contracted out through a DB occupational plan, there is a lower rate of social security contributions. In contrast, for a contracted-out DC pension plan, the employer and employee continue to pay the full rate of social security contributions (although there is a small reduction in the case of DC occupational plans), but the State makes a contribution to the plan, related to the employee's age. Contracted-out DB schemes must meet minimum benefit standards.

The government sets the social security rebates, reviewed every five years, on the advice of the Government Actuary. The rebates are designed to reflect the value of the state pension rights forgone as a result of being contracted out.

\section{Targeted}

The pension credit, introduced in 2003, targets a minimum income level. This is GBP 105.45 for 2004/05 (GBP 102.10 for 2003/04) for a single person. There is no requirement to have paid social security contributions to receive the pension credit. The credit is worth about one fifth of average earnings.

The pension credit also includes a "savings credit" in addition to the "guarantee credit" described above. This is designed to reduce the effective withdrawal rate of benefits from $100 \%$ under the old scheme to $40 \%$. Individuals whose income (apart from the pension credit) is less than the target minimum income, but more than a "starting point", receive a top up. The starting point is equal to the full value of the basic pension. The top up is $60 \%$ of income above the starting point. For people with incomes above the target minimum income, the benefit is reduced by $40 \%$ by the amount of the excess. The maximum savings credit for 2004/05 is therefore around (GBP 105 - GBP 80) x 60\% = GBP 15 per week for a single person.

\section{Pre-reform scenario}

The state second pension is an amended version of the state earnings-related pension scheme, known as Serps that was introduced from 2002-03. The Serps scheme was introduced in 1978 and substantially reformed in 1988.

The principal difference between the state second pension and Serps is the introduction of the differential replacement rate over different bands of earnings. The Serps scheme had a single accrual rate on all earnings between the lower and upper earnings limits. Following the 1988 reform, the target replacement rate was $20 \%$, giving an annual accrual rate of $20 / 49$ or $0.41 \%$ in the long term. Prior to 1988 , the target replacement rate was $25 \%$. Furthermore, the scheme was established with accelerated accrual for early generations. Only 20 years were required to receive a full pension, giving an accrual rate for someone retiring in $1998-99$ or before of $25 / 20$ or $1.25 \%$. This affects interim cohorts until people have spent a full career under Serps/state second pension (i.e., those reaching pension eligibility age after 2027-28).

The pre-reform scenario takes the long-term accrual rate for Serps including the full effect of the 1988 reform.

A subsequent reform replaced from 2003/04 the minimum income guarantee with the pension credit. The Mig is counted as part of the pre-reform system. The rate for the Mig used in the modelling is the same as the guarantee credit under the new pension credit.

The pre-reform scenario also includes the effect of the increase in pension age for women, since this formed part of a different, earlier reform. 


\section{Early retirement}

Early retirement is not possible in the public scheme.

\section{Late retirement}

Until April 2005, deferral of the state pension was possible until age 70. This earned an increment of $7.4 \%$ per year. From April 2005, the age limit for deferral will be removed and the increment will be increased to $10.4 \%$. Also, it will be possible instead to take a lump sum after the period of deferral. The amount of pension not claimed during the period of deferral will be paid at the end with an interest rate guaranteed to be at least two percentage points above the repo rate (the Bank of England base rate).

\section{Pension modelling results: United Kingdom}
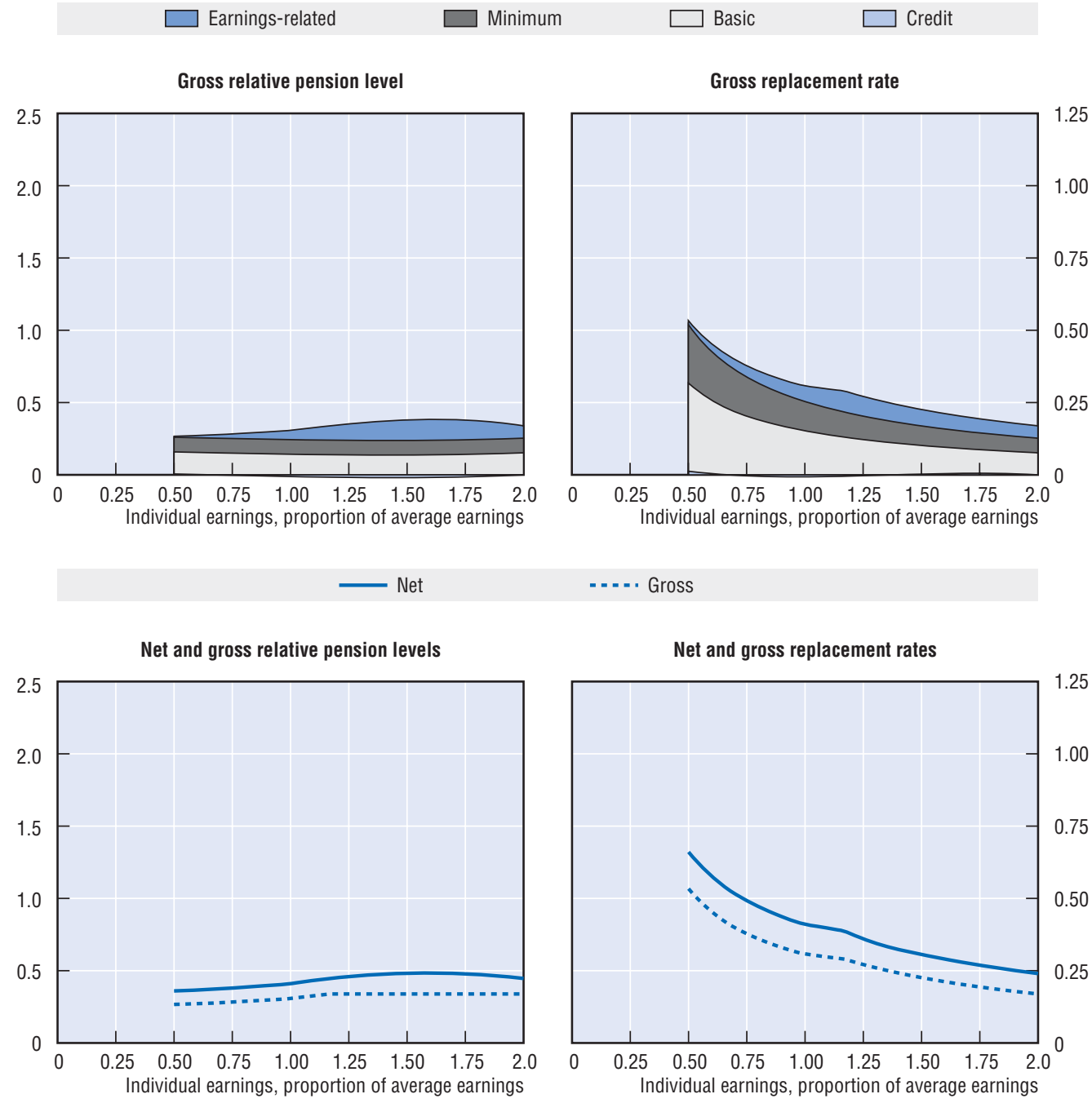


\begin{tabular}{|c|c|c|c|c|c|c|}
\hline \multirow{2}{*}{$\begin{array}{l}\text { Men } \\
\text { Women (where different) }\end{array}$} & \multirow{2}{*}{ Median earner } & \multicolumn{5}{|c|}{ Individual earnings, multiple of economy-wide average } \\
\hline & & 0.5 & 0.75 & 1 & 1.5 & 2 \\
\hline Gross relative pension level & 29.3 & 26.7 & 28.3 & 30.8 & 33.9 & 33.9 \\
\hline \multicolumn{7}{|l|}{ (\% average gross earnings) } \\
\hline Net relative pension level & 39.2 & 36.0 & 38.0 & 41.1 & 44.6 & 44.6 \\
\hline \multicolumn{7}{|l|}{ (\% net average earnings) } \\
\hline Gross replacement rate & 34.4 & 53.4 & 37.8 & 30.8 & 22.6 & 17.0 \\
\hline \multicolumn{7}{|l|}{ (\% individual gross earnings) } \\
\hline Net replacement rate & 45.4 & 66.1 & 49.2 & 41.1 & 30.6 & 24.0 \\
\hline \multicolumn{7}{|l|}{ (\% individual net earnings) } \\
\hline Gross pension wealth & 5.1 & 8.0 & 5.7 & 4.6 & 3.4 & 2.5 \\
\hline (multiple of individual gross earnings) & 5.9 & 9.1 & 6.5 & 5.3 & 3.9 & 2.9 \\
\hline Net pension wealth & 5.1 & 7.9 & 5.6 & 4.5 & 3.3 & 2.5 \\
\hline (multiple of individual gross earnings) & 5.8 & 9.1 & 6.4 & 5.2 & 3.8 & 2.8 \\
\hline
\end{tabular}

Pension modelling results: United Kingdom, pre-reform scenario

\begin{tabular}{|c|c|c|c|c|c|c|}
\hline \multirow{2}{*}{$\begin{array}{l}\text { Men } \\
\text { Women (where different) }\end{array}$} & \multirow{2}{*}{ Median earner } & \multicolumn{5}{|c|}{ Individual earnings, multiple of economy-wide average } \\
\hline & & 0.5 & 0.75 & 1 & 1.5 & 2 \\
\hline Gross relative pension level & 28.1 & 21.7 & 26.2 & 30.8 & 33.9 & 33.9 \\
\hline \multicolumn{7}{|l|}{ (\% average gross earnings) } \\
\hline Net relative pension level & 37.7 & 29.4 & 35.5 & 41.1 & 44.6 & 44.6 \\
\hline \multicolumn{7}{|l|}{ (\% net average earnings) } \\
\hline Gross replacement rate & 33.0 & 43.3 & 35.0 & 30.8 & 22.6 & 17.0 \\
\hline \multicolumn{7}{|l|}{ (\% individual gross earnings) } \\
\hline Net replacement rate & 43.7 & 53.9 & 45.9 & 41.1 & 30.6 & 24.0 \\
\hline \multicolumn{7}{|l|}{ (\% individual net earnings) } \\
\hline Gross pension wealth & 4.9 & 6.5 & 5.2 & 4.6 & 3.4 & 2.5 \\
\hline (multiple of individual gross earnings) & 5.7 & 7.4 & 6.0 & 5.3 & 3.9 & 2.9 \\
\hline Net pension wealth & 4.9 & 6.5 & 5.2 & 4.5 & 3.3 & 2.5 \\
\hline (multiple of individual gross earnings) & 5.6 & 7.4 & 6.0 & 5.2 & 3.8 & 2.8 \\
\hline
\end{tabular}




\section{United States}

$\mathrm{T}_{\mathrm{h}}$ he publicly provided pension benefit, known as social security, has a progressive benefit formula. There is also a means-tested top-up payment available for low-income pensioners.

\section{Qualifying conditions}

The pension age (called normal retirement age, or NRA) is between 65 and 66 in 2004, increasing to 67 in steps. Eligibility for retirement benefits depends on the number of years in which contributions are made with a minimum requirement of ten years' contributions. Early retirement is possible from 62 with reduced benefits.

\section{Benefit calculation}

\section{Earnings-related}

The benefit formula is progressive. The first USD 612 a month of relevant earnings attracts a 90\% replacement rate. The band of earnings between USD 612 and USD 3689 a month is replaced at $32 \%$. These thresholds are 22 and $133 \%$ of average earnings, respectively. A replacement rate of $15 \%$ applies between the latter threshold and the earnings ceiling. A 50\% dependants' addition is available to married couples where secondary earners have built up a smaller entitlement and for a qualifying dependent child.

Earlier years' earnings are revalued up to the year in which the recipient reaches age 60 in line with growth in economy-wide average earnings. There is no adjustment of earnings for years after age 60. The basic benefit is computed for payment at age 62 . Thereafter, the basic benefit is adjusted in line with prices. The benefit is based on career average earnings for the 35 highest years of earnings (after valorisation), including years with zero earnings if needed to total 35 years.

The earnings ceiling for both contributions and benefits is USD 87900 a year, corresponding to almost three times (290\%) average earnings uprated annually in line with growth in economy-wide earnings.

Pensions in payment are adjusted in line with prices.

\section{Minimum}

There is a minimum pension under social security. People earning less than a special minimum primary insurance amount are given a minimum pension that depends on their lifetime total years of coverage, varying between USD 32 for 11 years' coverage and USD 639 for 30 years. The threshold for this minimum pension was USD 9765 in 2004, or $32 \%$ of average earnings. (The threshold is defined formally as $15 \%$ of the "old law" contribution and benefit base.) The minimum pension does not affect the modelling results because the earnings range affected is below that presented.

\section{Targeted}

The United States provide a means-tested benefit for the elderly, known as supplemental security income. Single people over the age of 65 can be eligible for up to USD 6768 a year depending on assets and other income. The benefit rate for couples is 
USD 10152 (50\% higher than the rate for singles). These benefit rates are equivalent to around $22 \%$ and $33 \%$ of the national average wage, respectively. The benefit is indexed to prices.

The asset tests are strict: single people are limited to USD 2000 worth of assets and couples to USD 3000 , excluding personal belongings, a home, a car, funeral insurance and life insurance (the last two up to USD 1500 in value). There is a small (USD 20 a month) "disregard" in calculating the entitlement. The benefit is then withdrawn at a $100 \%$ rate against income above this level.

The analysis is complicated by the fact that states can supplement the federally determined minimum. While 12 states pay only the federal minimum, some 28 administer their own system and 12 offer supplements that are operated by the federal Social Security Administration. The average additional payment in these 12 states is $13 \%$ for single pensioners and $18 \%$ for couples. Note that the modelling does not include these additional payments.

\section{Early retirement}

Early retirement is possible from 62 , subject to an actuarial reduction. For the first three years of retirement before the normal age, the benefit is reduced by $6 / 3$ per cent per year. Thereafter, the reduction falls to $5 \%$. This applies to retirees with a normal retirement age (NRA) of over 65 . For retirees becoming eligible at age 62 in 2004, the normal retirement age is 65 years and ten months. This will increase gradually to reach 67 for people becoming eligible for retirement in 2022.

\section{Late retirement}

Initial receipt of the pension may be deferred until after NRA, and credit is given for deferment up to age 70 . The actuarial increment for 2004 is $7 \%$ for each year deferred. It will be $7.5 \%$ in $2006-07$ and $8 \%$ from 2008 onwards.

It is also possible to combine work and pension receipt subject to an earnings test. For beneficiaries under age of their NRA, the pension is reduced by $50 \%$ of earnings in excess of USD 11 640. For workers who have reached their NRA, there is no benefit reduction based on earnings. 
Pension modelling results: United States

Earnings-related
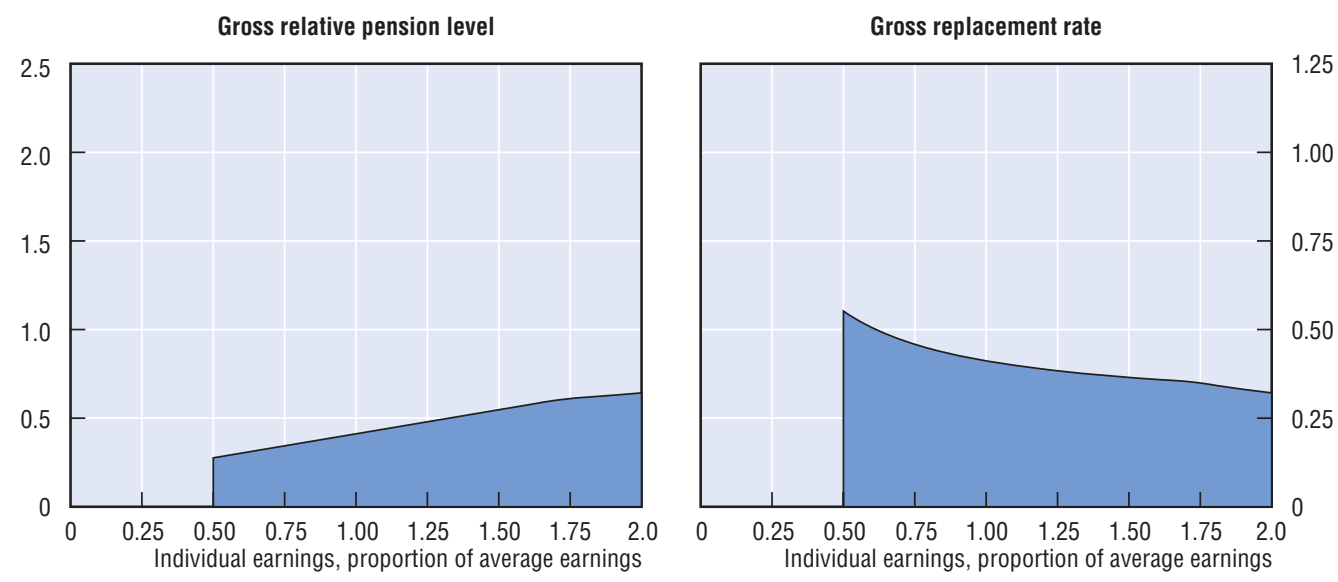

Net

. .... Gross

Net and gross relative pension levels

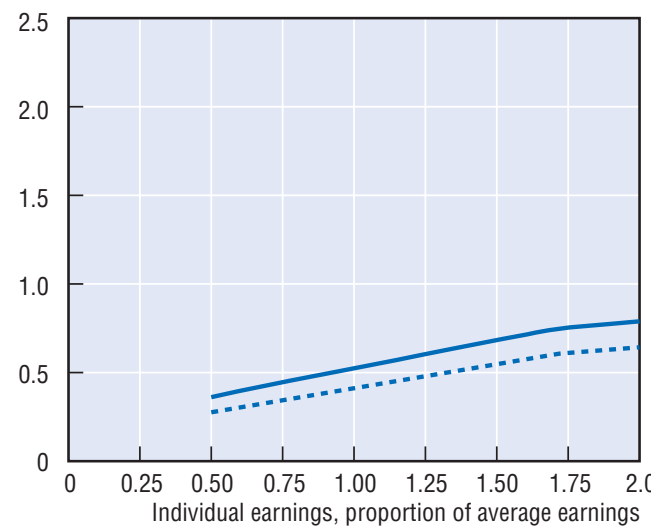

Net and gross replacement rates

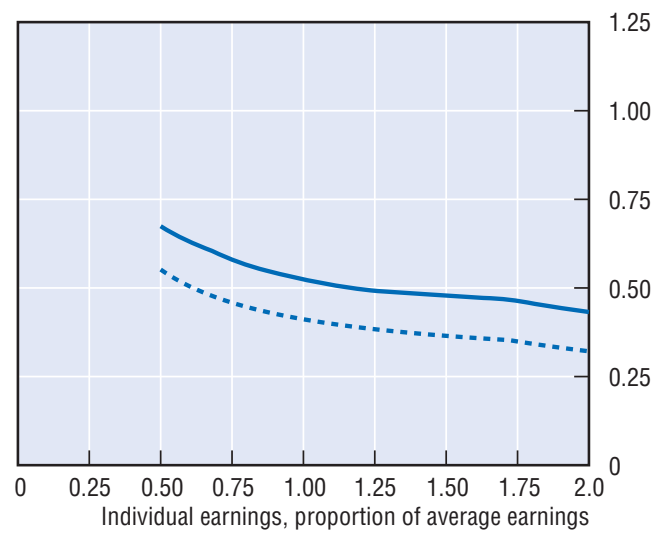

\begin{tabular}{|c|c|c|c|c|c|c|}
\hline \multirow{2}{*}{$\begin{array}{l}\text { Men } \\
\text { Women (where different) }\end{array}$} & \multirow{2}{*}{ Median earner } & \multicolumn{5}{|c|}{ Individual earnings, multiple of economy-wide average } \\
\hline & & 0.5 & 0.75 & 1 & 1.5 & 2 \\
\hline \multicolumn{7}{|l|}{ (\% average gross earnings) } \\
\hline Net relative pension level & 47.6 & 36.1 & 44.5 & 52.4 & 68.3 & 78.9 \\
\hline \multicolumn{7}{|l|}{ (\% net average earnings) } \\
\hline Gross replacement rate & 43.6 & 55.2 & 45.8 & 41.2 & 36.5 & 32.1 \\
\hline \multicolumn{7}{|l|}{ (\% individual gross earnings) } \\
\hline Net replacement rate & 55.3 & 67.4 & 58.0 & 52.4 & 47.9 & 43.2 \\
\hline \multicolumn{7}{|l|}{ (\% individual net earnings) } \\
\hline Net pension wealth & 6.1 & 7.9 & 6.5 & 5.7 & 5.0 & 4.3 \\
\hline (multiple of individual gross earnings) & 7.1 & 9.2 & 7.5 & 6.6 & 5.8 & 5.0 \\
\hline
\end{tabular}


OECD PUBLICATIONS, 2, rue André-Pascal, 75775 PARIS CEDEX 16 PRINTED IN FRANCE

(81 200707 1 P) ISBN 978-92-64-03214-9 - No. 555892007 


\section{Pensions at a Glance}

\section{PUBLIC POLICIES ACROSS OECD COUNTRIES}

Government-mandated pension and retirement policies have changed dramatically during the past decade. Pensions at a Glance presents a consistent framework for comparing public pension policies across OECD countries, as well as reliable data. The report thus provides the basis for not only evaluating existing pension systems, but also designing and implementing future reforms.

This second edition updates in-depth information on the key features of mandatory pension systems - both public and private - in the 30 OECD countries, including projections of retirement income for today's workers.

Two new and important sections have been added to this edition: 1) description and analysis of pension reform in OECD countries during the past decade; and 2) a closer look at the complex range of private, voluntary retirement plans now playing a greater role in pension provision in many OECD countries, including an analysis of the private savings effort required to maintain standards of living during retirement.

\section{About the first edition of Pensions at a Glance:}

"Pensions at a Glance deserves much more than a glance. It is a compendium of facts and analyses that should inform policymaking and public debate around the world for years to come. By providing in clear and easy-to-understand form a wealth of information about pension systems throughout the OECD, it will make it much harder for even the most insular to ignore the valuable lessons to be learned from the pension experience of other nations." - Henry J. Aaron, The Brookings Institution

Named one of 12 international "notable government documents" by the American Library Association.

\section{www.oecd.org/els/social/ageing/PAG}

The full text of this book is available on line via these links:

www.sourceoecd.org/finance/9789264032149

www.sourceoecd.org/socialissues/9789264032149

Those with access to all OECD books on line should use this link: www.sourceoecd.org/9789264032149

SourceOECD is the OECD's online library of books, periodicals and statistical databases.

For more information about this award-winning service and free trials ask your librarian, or write to us at SourceOECD@oecd.org.

OECDpublishing www.oecd.org/publishing

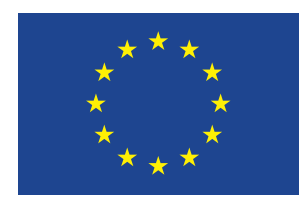

ISBN 978-92-64-03214-9 $812007071 \mathrm{P}$

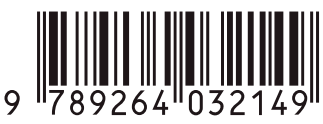

